M. Siarudin, Aji Winara, Yonky Indrajaya, Anas Badrunasar, Subekti Rahayu dan James M Roshetko 

Seri Agroforestri dan Kehutanan di Sulawesi:

\section{Keanekaragaman Hayati Jenis Pohon pada Hutan Rakyat Agroforestri di DAS Balangtieng, Sulawesi Selatan}

M. Siarudin, Aji Winara, Yonky Indrajaya, Anas Badrunasar, Subekti Rahayu dan James M Roshetko

Working paper 253
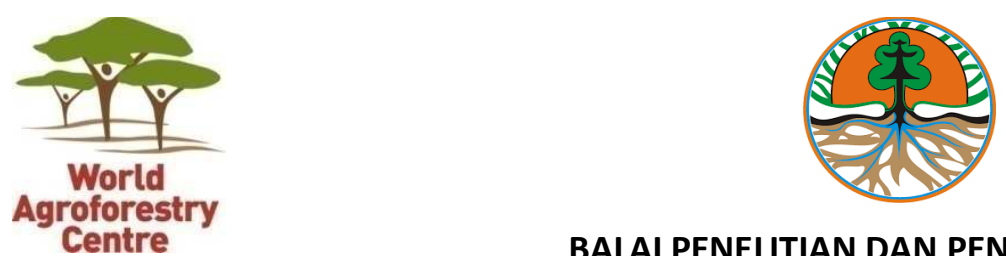


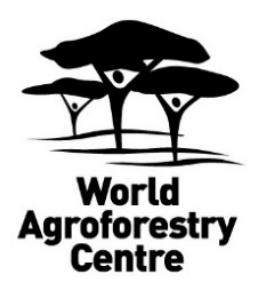

Correct citation:

Siarudin M, Winara A, Indrajaya Y, Badrunasar A, Rahayu S, Roshetko JM. 2017. Seri Agroforestry dan Kehutanan di Sulawesi: Keanekaragaman Hayati Jenis Pohon pada Hutan Rakyat Agroforestri di DAS Balangtieng, Sulawesi Selatan. Working paper no. 253. Bogor, Indonesia: World Agroforestry Centre (ICRAF) Southeast Asia Regional Program dan Balai Penelitian dan Pengembangan Teknologi Agroforestry (BPTA). http://dx.doi.org/10.5716/WP16182.PDF

Titles in the Working Paper series aim to disseminate interim results on agroforestry research and practices, and stimulate feedback from the scientific community. Other publication series from the World Agroforestry Centre include: Technical Manuals, Occasional Papers and the Trees for Change Series.

Published by the World Agroforestry Centre (ICRAF)

Southeast Asia Regional Program

JL. CIFOR, Situ Gede, Sindang Barang, Bogor 16680

PO Box 161, Bogor 16001, Indonesia

Tel: +62 2518625415

Fax: +622518625416

Email: icraf-indonesia@cgiar.org

ICRAF Southeast Asia website: http://www.worldagroforestry.org/region/southeast-asia/

(C) World Agroforestry Centre 2017

Working Paper 253

\section{Photographs:}

The views expressed in this publication are those of the author(s) and not necessarily those of the World Agroforestry Centre.Articles appearing in this publication may be quoted or reproduced without charge, provided the source is acknowledged. All images remain the sole property of their source and may not be used for any purpose without written permission of the source. 


\section{Tentang Penulis}

Mohamad Siarudin (Didien) menjadi peneliti di Badan Penelitian, Pengembangan dan Inovasi, Kementerian Lingkungan Hidup dan Kehutanan sejak tahun 2004 dan ditugaskan pada Balai Penelitian dan Pengembangan Teknologi Agroforestry, Ciamis (sebelumnya bernama Balai Penelitian Kehutanan Ciamis). Didien memperoleh gelar Sarjana Kehutanan dari Fakultas Kehutanan Universitas Gadjah Mada (UGM) dan gelar Master dibidang Perencanaan Wilayah dan Kota di Institut Teknologi Bandung (ITB) serta Media dan Governance di Keio University, Jepang. Pada tahun 2004 - 2009, Didien terlibat dalam beberapa penelitian di bidang social forestry baik di hutan rakyat maupun di kawasan hutan Negara. Sejak tahun 2012, Didien tergabung dengan Kelompok Peneliti Sumber Daya Lingkungan Hutan yang salah satu penelitiannya fokus pada jasa lingkungan pada system agroforestri di hutan rakyat.

Aji Winara (Aji) adalah peneliti Badan Penelitian, Pengembangan dan Inovasi, Kementerian Lingkungan Hidup dan Kehutanan sejak tahun 2004 dan saat ini ditugaskan pada Balai Penelitian dan Pengembangan Teknologi Agroforestry, Ciamis. Aji memulai karirnya sebagai peneliti di Balai Penelitian Kehutanan Papua dan Maluku yang berdomisili di Kabupaten Manokwari Papua Barat (2004-2011) dengan bidang penelitian Biodiversitas dan Manajemen Pengelolaan Kawasan Konservasi di Papua. Aji memperoleh gelar Sarjana Kehutanan (S1) dari Jurusan Konservasi Sumberdaya Hutan Fakultas Kehutanan Institut Pertanian Bogor (IPB) pada tahun 2001 dan memperoleh gelar Master Sains dari Program Studi Silvikultur Tropika Sekolah Pascasarjana IPB pada tahun 2014. Saat ini fokus penelitian yang digeluti Aji adalah Biodiversitas dan Perlindungan Hutan.

Yonky Indrajaya (Yonky) memulai karirnya sebagai penelitian di Litbang Kehutanan Surakarta pada tahun 2002 dengan fokus penelitian tentang hidrologi hutan dan pengelolaan Daerah Aliran Sungai (DAS). Setelah menyelesaikan masternya di bidang perencanaan wilayah di Institut Teknologi Bandung (ITB) dan University of Groningen (RuG) Belanda, pada tahun 2007, Yonky dipindahkan tugas di Litbang Kehutanan Ciamis. dan bergabung dengan kelompok peneliti Jasa Lingkungan. Yonky banyak terlibat di penelitian hutan rakyat dan agroforestry khususnya pada aspek pengelolaan hutan semenjak dia memulai sekolahnya di Wageningen University, Belanda di bidang ekonomi sumberdaya dan lingkungan pada tahun 2009. Bidang penelitian yang digeluti Yonky sekarang adalah bidang manajemen hutan, jasa lingkungan hutan dan perubahan iklim.

Anas Badrunasar (Anas) menjadi Teknisi Litkayasa memulai kariernya di Litbang Kehutanan Pematangsiantar (Sumatera Utara) dari tahun 1986-2003. Oktober 2003 beralih tugas ke Balai Penelitian dan Pengembangan Teknologi Agroforestry, Ciamis. Anas memperoleh gelar D-III Kehutanan dari Fakultas Kehutanan Universitas Gadjah Mada (UGM), Anas pernah terlibat dalam pembangunan hutan kota milik PT. Holcim Tbk. Indonesia (Cilacap), terlibat dalam beberapa penelitian di bidang social forestry baik di hutan rakyat maupun di kawasan hutan Negara. Sejak 
tahun 2012, Anas tergabung dengan Kelompok Peneliti Sumber Daya Lingkungan dan dilibatkan dalam penelitian jasa lingkungan pada system agroforestri di hutan rakyat.

Subekti Rahayu adalah peneliti mengenai keanekaragaman hayati dan cadangan karbon di World Agroforestry Centre. Penelitian yang dilakukan terkait dengani konservasi keanekaragaman hayati, restorasi ekologi, ekologi hutan dan agroforestri serta fungsi keanekaragaman hayati sebagai indikator dalam ekologi. Kandindat Doktor pada Institut Pertanian Bogor dengan disertasi berjudul Model Restorasi Hutan Bekas Terbakar KHDTK Samboja, Kalimantan Timur ini mendapatkan gelar Magister Sains pada Konservasi Biodiversitas Tropika, Institut Pertanian Bogor. Gelar Sarjana Pertanian diperoleh dari Jurusan Proteksi Tanaman universitas yang sama. Penelitian mengenai pengukuran cadangan karbon pada tingkat petak telah dilakukan sejak tahun 1998. Pelatihan mengenai pengukuran cadangan telah diberikan di berbagai lembaga di Indonesia dan Vietnam. Pengembangan metode pemantauan dan evaluasi keanekaragaman bersama masyarakat sipil telah dilakukan melalui serangkaian uji-coba di Provinsi Papua dan Jambi. Metode pemantauan dan evaluasi yang lebih spesifik pada pertumbuhan pohon dalam program rehabilitasi dan restorasi hutan berbasis masyarakat telah dibangun berdasarkan pembelajaran dari Kabupaten Kendari dan Buol.

James M Roshetko adalah peneliti di bidang Sistem Agroforestri yang saat ini juga memiliki posisi sebagai Kepala Unit Trees, Agroforest Management and Market -World Agroforestry Centre (ICRAF) Asia Tenggara. Beliau memiliki pengalaman kerja 37 tahun, termasuk 19 tahun di Indonesia dan 28 di Asia Tenggara dan Asia Selatan. Fokus penelitiannya saat ini adalah sistem pertanian skala kecil yang berbasis pohon sebagai sebuah sistem pengelolaan pertanian dan sumber daya alam berkelanjutan yang berkontribusi secara nyata terhadap pengembangan ekonomi lokal sekaligus pelestarian lingkungan secara global. James menyandang gelar doktor dalam bidang Ilmu Bumi dan Pengelolaan Sumber Daya Alam dari University of Copenhagen, Denmark and gelar master dalam bidang Pengelolaan Hutan dan Agoroforestri dari Michigan State University, USA. 


\section{Abstrak}

Agroforestri merupakan sistem penggunaan lahan yang banyak dipraktekkan oleh masyarakat di wilayah Daerah Aliran Sungai (DAS) Balangtieng, Sulawesi Selatan. Dalam konteks pengelolaan suatu DAS, sistem agroforestri memiliki peran penting tidak hanya sebagai penyedia produk kayu dan perkebunan tetapi juga jasa lingkungan air, karbon dan keanekaragaman jenis tumbuhan dan satwa. Penelitian ini dimaksudkan untuk mengidentifikasi dan mengkaji nilai keanekaragaman jenis pohon, serta manfaatnya bagi masyarakat di DAS Balangtieng. Penelitian dilaksanakan di wilayah DAS Balangtieng yang merupakan secara administratif terletak pada 4 Kabupaten di Provinsi Sulawesi Selatan, yaitu Bulukumba, Bantaeng, Gowa dan Sinjai yang meliputi 37 desa dalam 6 kecamatan. Pengamatan keanekaragaman jenis pohon dilakukan dengan metode Quick Biodiversity Survey (QBS) yang merupakan pelengkap dari metode Rapid Agro-Biodiversity Appraisal (RABA). Pengamatan dilaksanakan pada 120 plot yang mewakili 6 Sistem Penggunaan Lahan (SPL) agroforestri, yaitu: Sistem kelapa, sistem jambu mete, sistem coklat, sistem cengkeh, sistem kopi dan sistem kebun campuran. Pengamatan juga dilakukan pada kawasan hutan yang ada di wilayah DAS Balangtieng sebagai pembanding. Selain itu wawancara dan kuisioner dilakukan terhadap 29 petani pemilik lahan untuk mengetahui pemanfaatan jenis pohon yang dilakukan oleh masyarakat. Hasil penelitian menunjukkan bahwa tingkat keanekaragaman hayati dan kekayaan jenis tumbuhan pepohonan pada berbagai SPL agroforestry di sekitar DAS Balangtieng tergolong rendah hingga sedang dengan tingkat keanekaragaman hayati tertinggi berada pada agroforestry kebun campuran dan terendah pada agroforestry jambu mete dengan tingkat kesamaan komunitas antar SPL tergolong rendah hingga sedang. Sebagian besar struktur vegetasi agroforestry di sekitar DAS Balangtieng tidak normal dan kurang menjamin proses regenerasi alami tumbuhan disebabkan adanya pengelolaan yang intensif. Sistem perkebunan intensif menyebabkan berkembangnya jenis-jenis komersil dengan nilai ekonomi tinggi (cengkeh, lada) dan cepat tumbuh (gmelina, suren, afrika) disisi lain menjadi salah satu sebab berkurangnya jenis-jenis asli yang tidak komersial/kurang dikenal atau berdaur lama (seperti pohon Laniki, Bae, Bulo, Rita, Bilalang, Asa dll). Hal ini diindikasikan dengan sebagian besar jenis pohon di hutan alam tidak ditemukan di lahan agroforestry lahan milik. Masyarakat memanfaatkan jenis-jenis pohon untuk makanan, bahan bangunan, obat-obatan dan perkakas rumah tangga. Sebagian besar tujuan pemanfaatan adalah untuk konsumsi/subsisten, dan sebagian lainnya untuk tujuan komersil khususnya pada jenis-jenis yang dibudidayakan secara intensif.

Kata kunci: Agroforestri, keanekaragaman jenis, Sistem Penggunaan Lahan, Daerah Aliran Sungai 


\section{Ucapan terima kasih}

Working paper ini disusun oleh Balai Penelitian dan Pengembangan Teknologi Agroforestry (BPTA) bekerja sama dengan World Agroforestry Centre (ICRAF) Asia Tenggara dalam proyek "Agroforestry dan Kehutanan (AgFor) Sulawesi: Menghubungkan pengetahuan dengan tindakan" yang didanai oleh Global Affairs Canada (sebelumnya dikenal dengan nama Department of Foreign Affairs, Trade and Development). 


\section{Daftar isi}

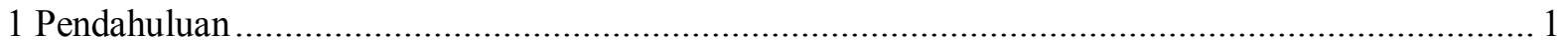

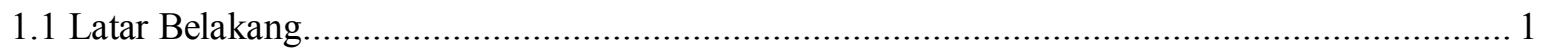

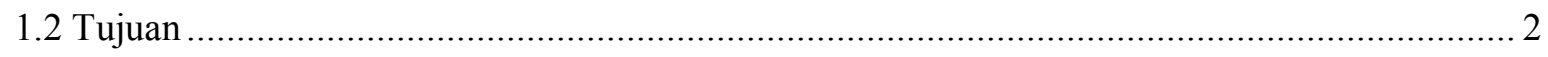

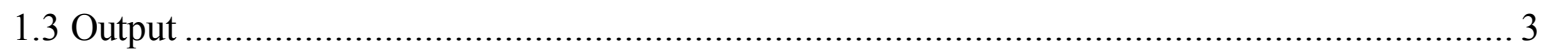

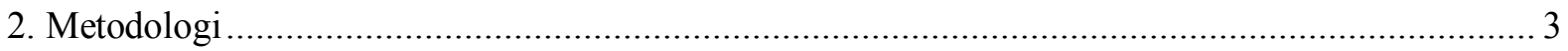

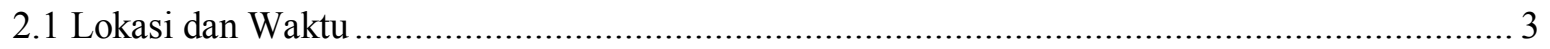

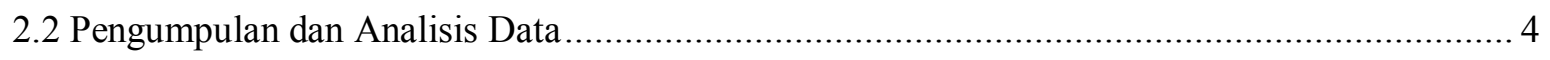

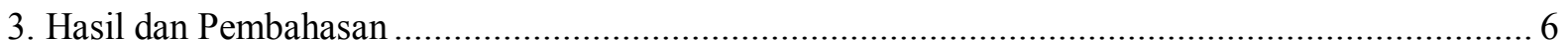

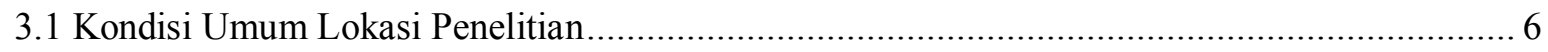

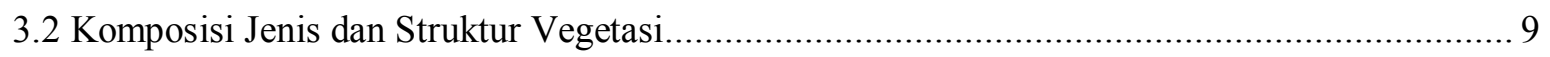

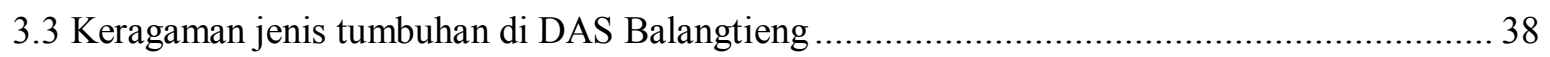

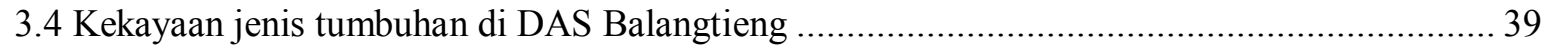

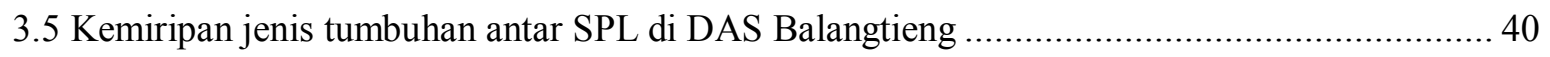

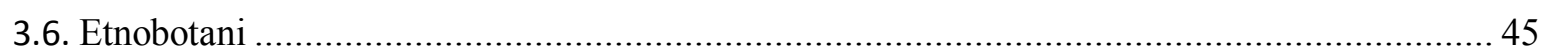

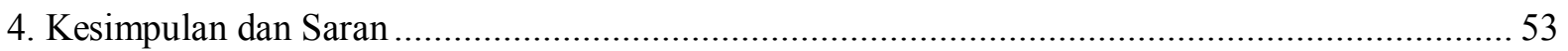

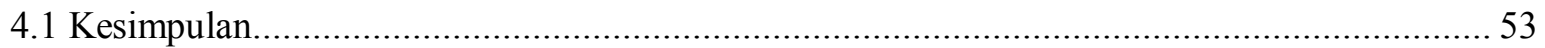

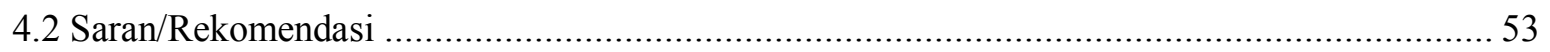

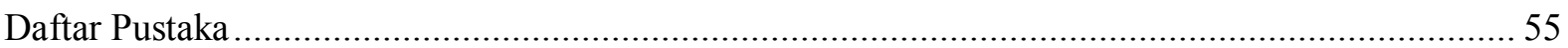




\section{Daftar Gambar}

Gambar 2.1 Peta DAS Balantieng, Sulawesi Selatan.................................................................. 3

Gambar 2.2 Petak bersarang untuk analisis vegetasi berdasarkan metode QBS .............................. 5

Gambar 3.1 Kondisi sungai utama DAS Balangtieng bagian hulu (A), tengah (B) dan hilir (C),....... 8

Gambar 3.2 Diagram profil tegakan pada sistem agroforestry kelapa + coklat.................................. 12

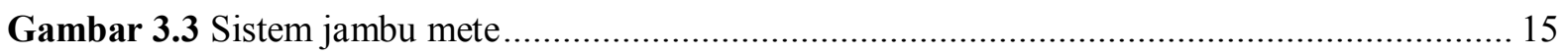

Gambar 3.4 Diagram profil tegakan pada sistem agroforestry coklat........................................... 17

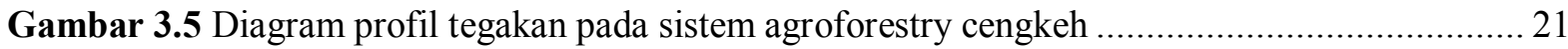

Gambar 3.6 Agroforestry cengkeh yang dikombinasikan dengan lada dengan tanaman gamal

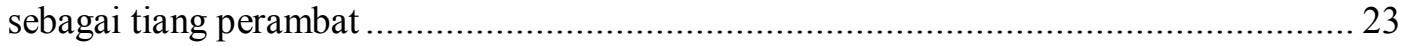

Gambar 3.7 Diagram profil tegakan pada sistem agroforestry kopi ............................................. 24

Gambar 3.8 Diagram profil tegakan pada sistem kebun campuran ................................................ 30

Gambar 3.9 Diagram profil tegakan pada hutan sekunder di dataran rendah (kiri) dan dataran

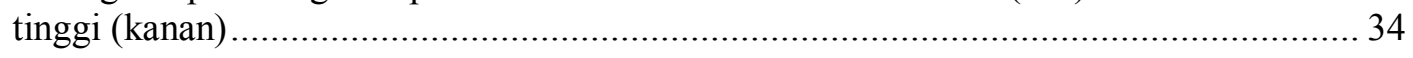

Gambar 3.10 Vegetasi hutan primer di wilayah hulu DAS Balangtieng........................................ 38

Gambar 3.11 Nilai keragaman hayati tumbuhan pada setiap SPL di sekitar DAS Balangtieng,

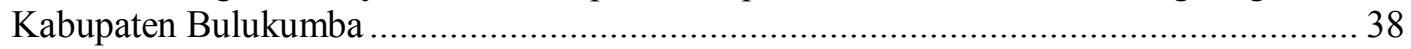

Gambar 3.12 Nilai kekayaan jenis tumbuhan pada setiap SPL di sekitar DAS Balangtieng,

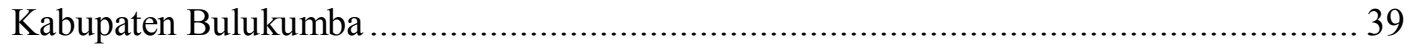

Gambar 3.13 Jumlah jenis pohon berdasarkan kelompok famili................................................... 45

Gambar 3.14 Jumlah jenis dan famili pohon yang dimanfaatkan masyarakat ............................... 45

Gambar 3.15 Jenis pohon berdasarkan jumlah responden yang memanfaatkan.............................. 46

Gambar 3.16 Rumah panggung yang berbahan baku kayu di lokasi penelitian ................................ 51

Gambar 3.17 Gerbang dari kayu/bambu yang dibuat pada saat berlangsung pesta pernikahan ......... 53 


\section{Daftar Table}

Tabel 2.1 Jumlah dan sebaran lokasi plot pengamatan pada berbagai SPL di DAS Balantieng ........... 4

Tabel 3.1 Jumlah produksi dan luas perkebunan di Kabupaten Bulukumba ....................................... 7

Tabel 3.2 Pembagian luas DAS Balantieng menurut kelas kelerengan ............................................ 8

Tabel 3.3 Pembagian luas DAS Balantieng menurut Ordo tanah.................................................. 9

Tabel 3.4 Kerapatan populasi spesies tumbuhan berdasarkan tingkat pertumbuhan pada agroforestry kelapa di sekitar DAS Balangtieng Kabupaten Bulukumba .......................................... 10

Tabel 3.5 Struktur Vegetasi dan Indeks Nilai Penting Agroforestry Kelapa di sekitar DAS Balangtieng Kabupaten Bulukumba.

Tabel 3.6 Kerapatan populasi jenis tumbumbuhan berdasarkan tingkat pertumbuhan pada agroforestry Jambu Mete di sekitar DAS Balangtieng Kabupaten Bulukumba

Tabel 3.7 Struktur Vegetasi Agroforestry Jambu Mete di sekitar DAS Balangtieng Kabupaten Bulukumba

Tabel 3.8 Kkerapatan populasi jenis tumbuhan berdasarkan tingkat pertumbuhan pada agroforestry Coklat di sekitar DAS Balangtieng Kabupaten Bulukumba

Tabel 3.9 Struktur Vegetasi Agroforestry Coklat di sekitar DAS Balangtieng Kabupaten Bulukumba

Tabel 3.10 Kerapatan populasi jenis tumbumbuhan berdasarkan tingkat pertumbuhan pada agroforestry Cengkeh di sekitar DAS Balangtieng Kabupaten Bulukumba

Tabel 3.11 Struktur Vegetasi Agroforestry Cengkeh di sekitar DAS Balangtieng Kabupaten Bulukumba

Tabel 3.12 Kerapatan populasi jenis tumbuhan berdasarkan tingkat pertumbuhan pada agroforestry Kopi di sekitar DAS Balangtieng Kabupaten Bulukumba

Tabel 3.13 Struktur Vegetasi Agroforestry Kopi di sekitar DAS Balangtieng Kabupaten Bulukumba

Tabel 3.14 Kerapatan populasi jenis tumbuhan berdasarkan tingkat pertumbuhan pada agroforestry Kebun Campuran di sekitar DAS Balangtieng Kabupaten Bulukumba

Tabel 3.15 Struktur Vegetasi Agroforestry Kebun Campuran di sekitar DAS Balangtieng Kabupaten Bulukumba

Tabel 3.16 Kerapatan populasi jenis tumbuhan berdasarkan tingkat pertumbuhan di hutan sekunder sekitar DAS Balangtieng Kabupaten Bulukumba

Tabel 3.17 Struktur Vegetasi hutan sekunder di sekitar DAS Balangtieng Kabupaten Bulukumba ... 32

Tabel 3.18 Kerapatan populasi jenis tumbuhan berdasarkan tingkat pertumbuhan di hutan alam

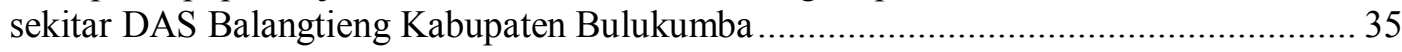

Tabel 3.19 Struktur Vegetasi hutan alam di sekitar DAS Balangtieng Kabupaten Bulukumba.......... 36

Tabel 3.20 Nilai indeks kesamaan jenis Sorrensen tingkat semai pada beberapa SPL di sekitar DAS Balangtieng, Kabupaten Bulukumba....

Tabel 3.21 Nilai indeks kesamaan jenis Sorrensen tingkat sapihan pada beberapa SPL di sekitar DAS Balangtieng, Kabupaten Bulukumba.

Tabel 3.22 Nilai indeks kesamaan jenis Sorrensen tingkat pancang pada beberapa SPL di sekitar DAS Balangtieng, Kabupaten Bulukumba. 
Tabel 3.23 Nilai indeks kesamaan jenis Sorrensen tingkat pohon pada beberapa SPL di sekitar DAS Balangtieng, Kabupaten Bulukumba....

Tabel 3.24 Sebaran kerapatan mutlak jenis pohon pada beberapa SPL di sekitar DAS Balangtieng, Kabupaten Bulukumba

Tabel 3.25 Pemanfaatan jenis pohon oleh masyarakat di wilayah DAS Balangtieng

\section{Daftar Lampiran}

Lampiran 3.1 Pemanfaatan jenis tumbuhan untuk makanan di DAS Balantieng....

Lampiran 3.2 Pemanfaatan jenis tumbuhan untuk obat-obatan di DAS Balantieng.....

Lampiran 3.3 Pemanfaatan jenis tumbuhan untuk bahan bangunan di DAS Balantieng.....

Lampiran 3.4 Pemanfaatan jenis tumbuhan untuk peralatan rumah tangga ....................................... 69

Lampiran 3.5 Pemanfaatan jenis tumbuhan untuk bahan bangunan di DAS Balantieng.................... 70

Lampiran 3.6 Pemanfaatan jenis tumbuhan untuk peralatan rumah tangga ..................................... 72

Lampiran 3.7 Pemanfaatan jenis tumbuhan untuk kayu bakar................................................... 73

Lampiran 3.8 Pemanfaatan jenis tumbuhan untuk budaya............................................................ 74 


\section{Pendahuluan}

\subsection{Latar Belakang}

Indonesia sesungguhnya negeri yang sangat kaya dan unik, dengan 17.560 pulau yang tersebar di hamparan khatulistiwa, diapit dua samudera Hindia dan Pasifik, dan juga dua benua Asia dan Australia, maka dengan kondisi alam seperti itu, terkandung banyak ekosistem dengan keanekaragaman hayati yang jarang dimiliki oleh bangsa lain di dunia. Tak heran jika Indonesia menduduki peringkat pertama di dunia untuk keanekaragaman jenis kupu-kupu, nomor dua untuk mamalia, nomor tiga untuk reptilia dan sebagainya yang semuanya terhampar dalam jutaan hektar hutan dan ber mil-mil kawasan laut kita.

Meskipun demikian, dari potensi yang demikian besar, belum semua bisa teridentiifikasi jenis dan sifat-sifatnya. Bahkan yang sudah teridenfikasi pun belum diketahui semua manfaatnya. Hutan hujan tropis kita berperan sangat besar dalam menjaga keanekaragam hayati atau biodiversity kita dengan luas total 98,56 juta ha (Statistik Kehutanan 2011), dan satu-satunya yang tersebar di ribuan pulau. Berbeda dengan hutan tropis "raksasa" lainnya, di Brasil dan Kongo misalnya, yang hanya "terkumpul" pada satu kawasan/daratan saja.

Pengelolaan hutan dan kawasan konservasi, termasuk upaya rehabilitasi lahan dan peningkatan kesejahteraan masyarakat di sekitar hutan, telah memprogramkan pengembangan hutan kemasyarakatan Kepmenhut No. 311/Kpts-II/2001, tentang penyelenggaraan hutan kemasyarakatan, hutan tanaman, dan hutan rakyat dalam bentuk agroforestri. Sebagai paradigma baru dalam pengelolaan hutan, pelaksanaan hutan kemasyarakatan yang dipadukan dengan model agroforestri diharapkan dapat melestarikan hutan alam melalui peningkatan produktivitas lahan hutan di areal masyarakat atau di lahan kritis.

Agroforestri diharapkan mampu meningkatkan ekonomi masyarakatnya melalui diversifikasi penanaman tanaman pangan, pohon dan pemeliharaan ternak sekaligus mempertahankan kelestarian lingkungan. Usaha tersebut juga bermanfaat untuk membangun kembali layanan-layanan ekosistem melalui penyediaan bahan pangan, energi, keanekaragaman hayati, pengembangan pengetahuan, sosial-budaya, layanan-layanan pendukung produksi pertanian seperti siklus nutrisi dan pengendalian hama penyakit.

Dalam konteks pengelolaan suatu DAS, agroforestri memiliki peran penting tidak hanya sebagai penyedia jasa lingkungan air dan karbon tetapi juga menjaga keanekaragaman tumbuhan dan hewan. Beberapa hasil penelitian di Bungo mengindikasikan bahwa kebun karet campur memiliki peran yang cukup penting sebagai penampungan jenis- jenis kehidupan hutan. Beberapa jasa lingkungan juga dapat disediakan dari kebun karet campur dengan level yang masih ada di bawah hutan.

Bismark dan Sawitri (2006) menyebutkan agroforestri yang terletak dekat hutan alam terdapat komponen jenis tumbuhan hutan yang beragam. Agroforestri di Krui Lampung dan di Maninjau 
Sumatera Barat terdapat 300 spesies tumbuhan. Jenis tumbuhan hutan di desa sekitar Gunung Halimun mencapai 464 jenis dan dimanfaatkan oleh masyarakat untuk kepentingan bangunan, sumber pakan, obat tradisional, kayu bakar, pakan ternak, dan upacara adat sejumlah 464 jenis (Harada et al 2001).

Agroforestri yang sudah tertata dengan keanekaragaman jenis tinggi dan komposisi tajuk yang baik dapat menjadi habitat dari beberapa jenis satwa, seperti primata, beruang, dan mamalia teresterial. Peran satwa tersebut dapat sebagai penyebar biji-bijian yang membantu proses regenerasi dan peningkatan keanekaragaman tumbuhan. Jumlah spesies mamalia yang ditemukan di agroforestri durian 33 jenis, di hutan karet 39 jenis, dan hutan damar 46 jenis dengan jenis yang dilindungi masing-masing 14, 15, dan 17 jenis (Michon et al 2000).

Pengembangan hutan rakyat dengan sistem agroforestri memiliki manfaat ekonomis dan ekologis untuk konservasi jenis satwa di luar dan di dalam kawasan hutan. Hal ini karena hutan rakyat yang memiliki struktur vegetasi menyerupai hutan alam merupakan habitat satwaliar untuk burung dan mamalia mencari pakan burung berupa biji-bijian dan serangga. Keragaman tanaman yang dusahakan antara tanaman tahunan dan tanaman pertanian memungkinkan terjadinya rantai makanan dan energi yang lebih panjang. Kondisi ini selanjutnya akan mendukung terciptanya keragaman hayati yang tinggi .

Informasi mengenai keanekaragaman hayati pada penggunaan lahan milik/hutan rakyat di DAS Balangtieng saat ini masih sangat terbatas. Penelitian ini dimaksudkan untuk mengidentifikasi keanekaragaman hayati, serta mengkaji nilai biodiversiti dalam kaitannya dengan manfaatnya bagi masyarakat di DAS Balangtieng. Hasil penelitian ini diharapkan dapat menjadi dasar pengelolaan DAS Balangtieng dalam rangka pemanfaatan lahan hutan rakyat pola agroforestri yang dapat memberikan keuntungan secara berkelanjutan baik dari aspek sosial ekonomi maupun lingkungan. Melalui pengelolaan lahan hutan rakyat pola agroforestry yang berkelanjutan ini pula, diharapkan tekanan pada kawasan hutan di Wilayah Sungai Jeneberang akan berkurang dan dapat mendukung pulihnya daya dukung DAS.

\subsection{Tujuan}

Penelitian ini bertujuan untuk:

1. Mengidentifikasi kondisi tegakan dan keanekaragaman jenis tumbuhan (pohon) pada berbagai tipe pengelolaan lahan di lahan agroforestry di DAS Balangtieng

2. Mengkaji nilai biodiversitas dalam kaitannya dengan manfaatnya bagi masyarakat di DAS Balangtieng 


\subsection{Output}

Output yang akan dihasilkan dari penelitian ini adalah:

1. Struktur vegetasi dan keanekaragaman jenis pohon pada berbagai sistem penggunaan lahan agroforestry di DAS di DAS Balangtieng

2. Informasi etnobotani (pemanfaatan jenis pohon oleh masyarakat) di DAS Balangtieng

\section{Metodologi}

\subsection{Lokasi dan Waktu}

Penelitian ini dilaksanakan di DAS Balantieng, yang secara administratif berada di tiga kabupaten, yaitu: Kabupaten Bulukumba, Kabupaten Bantaeng, dan Kabupaten Sinjai. Sebagian besar wilayah DAS ini berada di Kabupaten Bulukumba. Lokasi ini dipilih karena mewakili DAS yang berada di Kabupaten Bulukumba, yang merupakan salah satu lokasi kegiatan AgFor. Lokasi penelitian ini disajikan dalam Gambar 2.1.

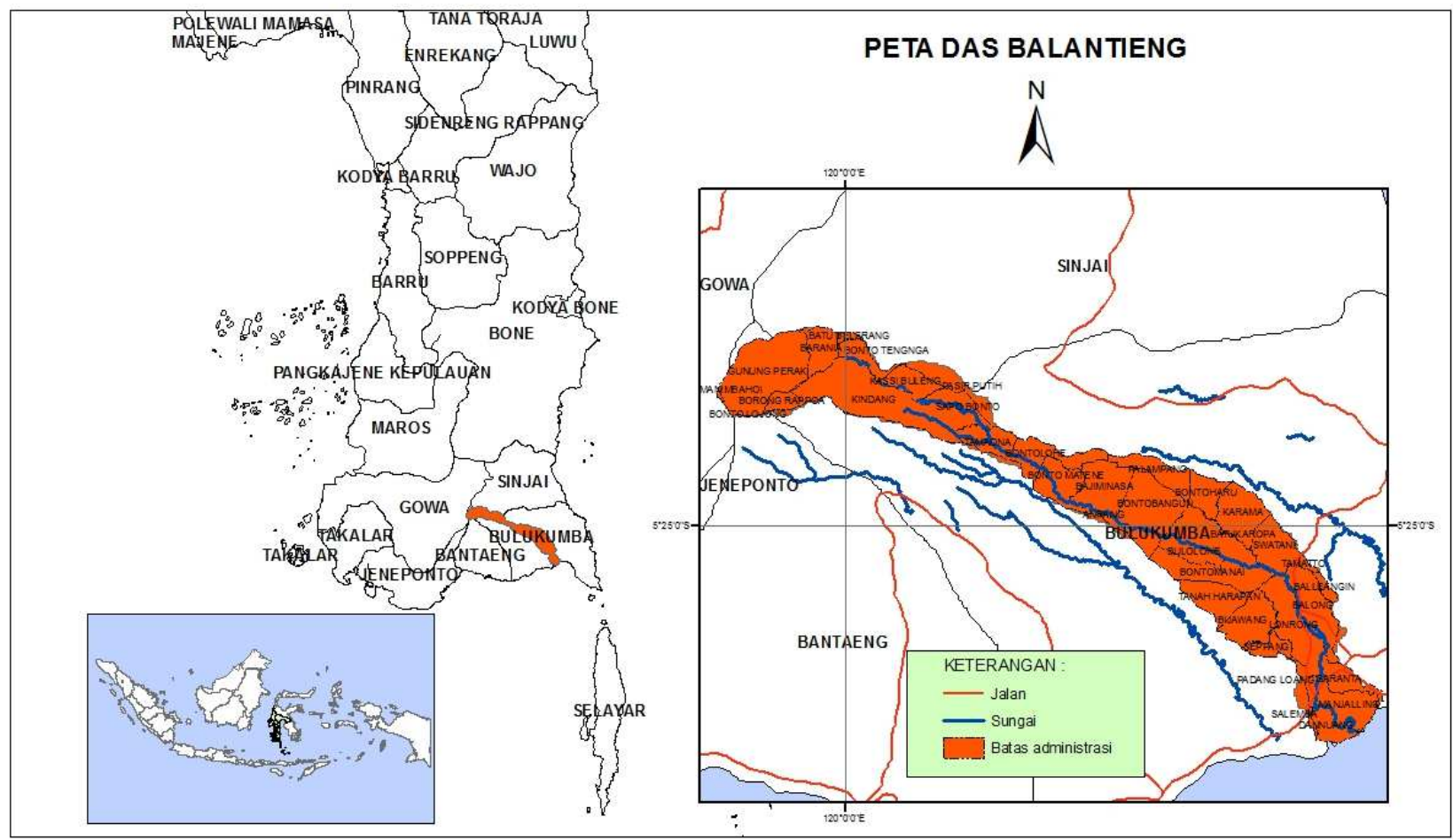

Gambar 2.1 Peta DAS Balantieng, Sulawesi Selatan

Pengamatan keanekaragaman jenis pohon pada hutan rakyat agroforestry didasarkan pada pola-pola tutupan lahan berbasis pohon yang ada di DAS Balantieng (Tabel 2.1). Selain hutan rakyat agroforestry juga dilakukan pengamatan pada kawasan hutan primer dan hutan sekunder (logged over area) yang ada di DAS Balangtieng. Pemilihan titik pengamatan dilakukan secara sengaja pada lokasi 
yang didominasi oleh masing-masing sistem penggunaan lahan (SPL). Pemilihan lokasi juga mempertimbangkan keterwakilan berdasarkan sebarannya pada DAS (hulu, tengah dan hilir).

Tabel 2.1 Jumlah dan sebaran lokasi plot pengamatan pada berbagai SPL di DAS Balantieng

\begin{tabular}{lcl}
\hline Sistem Penggunaan Lahan & Jumlah Plot & Lokasi pada DAS \\
\hline Sistem kelapa & 15 & Hilir \\
\hline Sistem jambu mete & 10 & Hilir \\
\hline Sistem coklat & 15 & Tengah \\
\hline Sistem cengkeh & 15 & Tengah, Hulu \\
\hline Sistem kopi & 10 & Hulu \\
\hline Sistem kebun campuran & 20 & Hilir, Tengah, Hulu \\
\hline Hutan primer & 15 & Hulu \\
\hline Hutan sekunder & 15 & Tengah, Hulu \\
\hline TOTAL & $\mathbf{1 2 0}$ & \\
\hline
\end{tabular}

Eksplorasi pemanfaatan jenis oleh masyarakat (etnobotani) dilakukan melalui wawancara terhadap petani pemilik lahan hutan rakyat agroforestry. Total responden adalah 30 orang, dari Desa Swatani, Kec. Rilau Ale (mewakili DAS hilir), Desa Bulolohe, Kec. Rilau Ale (mewakili DAS tengah) dan Desa Kindang, Kec. Kindang (mewakili DAS hulu).

Kegiatan pengambilan data di lapangan dan wawancara dilaksanakan pada bulan April-Mei 2015, dengan beberapa persiapan (penyiapan rancangan survei dan koordinasi dengan pemerintah daerah setempat). Analisis herbarium pada jenis-jenis pohon yang belum dikenal nama ilmiahnya dilaksanakan di Lembaga Ilmu Pengetahuan Indonesia pada Bulan Juni-Juli 2015. Pengolahan data dan analisis serta penulisan working paper ini dilaksanakan pada Bulan Agustus 2015 sampai dengan April 2016.

\subsection{Pengumpulan dan Analisis Data}

Pengamatan keanekaragaman jenis pohon dilakukan dengan metode Quick Biodiversity Survey (QBS) (Joshi et al., 2008) yang merupakan pelengkap dari metode Rapid Agro-Biodiversity Appraisal (RABA) (Kuncoro et al., 2006). Berdasarkan metode ini, setiap plot pengamatan dilakukan analisis vegetasi dengan petak bersarang. Setiap unit pengamatan berupa petak seluas $20 \mathrm{~m}$ x $100 \mathrm{~m}$, terdiri dari 5 buat petak berukuran $20 \mathrm{~m}$ x $20 \mathrm{~m}$ yang di dalamnya terdapat beberapa sub-petak (Gambar 2.2). Pengukuran vegetasi dilakukan berdasarkan tingkat pertumbuhan sebagai berikut:

- Petak 2 m x 2 m untuk pengamatan anakan pohon (seedling) yang berukuran tinggi kurang dari 2 m.

- Petak $5 \mathrm{~m}$ x $5 \mathrm{~m}$ untuk pengamatan sapihan pohon (sapling) yang berukuran diameter tinggi lebih dari $2 \mathrm{~m}$ dan diameter kurang dari $5 \mathrm{~cm}$.

- Petak $10 \mathrm{~m}$ x $10 \mathrm{~m}$ untuk pengamatan pancang (pole) yang berukuran diameter antara $5-10 \mathrm{~cm}$.

- Petak $20 \mathrm{~m}$ x $20 \mathrm{~m}$ untuk pengamatan pohon (tree) yang berukuran diameter lebih dari $10 \mathrm{~cm}$ 


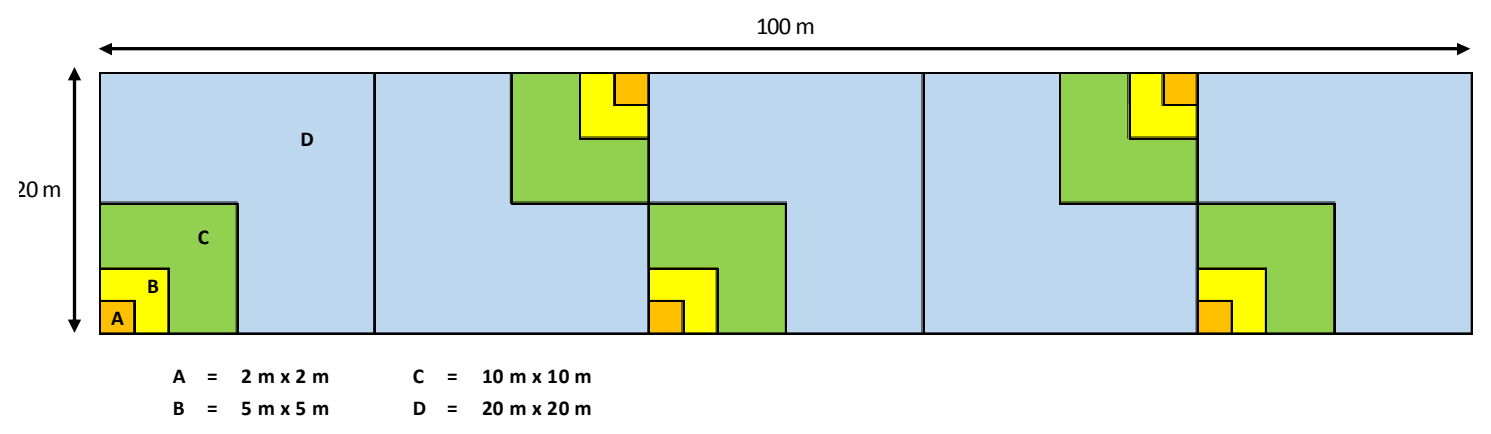

Gambar 2.2 Petak bersarang untuk analisis vegetasi berdasarkan metode QBS

Hasil pengukuran pada petak bersarang dianalisis struktur vegetasinya berupa nilai kerapatan (K), kerapatan relatif (KR), frekuensi (F), frekuensi relatif (FR), basal area (luas bidang dasar) (D), basal area relatif (DR), dan index nilai penting (INP). Selanjutnya data juga dianalisis keanekaragaman jenisnya berupa nilai indeks keanekaragaman jenis ( $\left.H^{\prime}\right)$, indeks kekayaan jenis ( $\left.R^{\prime}\right)$, dan indeks kesamaan jenis Sorrensen kualitatif $\left(C_{N}\right)$ berdasarkan Magurran (1955).

$$
\begin{aligned}
& \mathrm{INP}=\mathrm{KR}+\mathrm{FR}+\mathrm{DR} \\
& \mathrm{H}^{\prime}=-\sum_{i=1}^{n}\left(\frac{\mathrm{ni}}{\mathrm{N}}\right) \operatorname{Ln}\left(\frac{\mathrm{ni}}{\mathrm{N}}\right) \\
& \mathrm{R}^{\prime}=\sum_{k=1}^{n} \frac{\mathrm{S}-1}{\mathrm{Ln} \mathrm{N}} \\
& \mathrm{CN}=\frac{2 \mathrm{jN}}{(\mathrm{Na}+\mathrm{Nb})} \\
& \text { Kerapatan }=\frac{\text { Jumlah Individu Suatu Jenis }}{\text { Jumlah Seluruh Sampling Unit }} \times 100 \% \\
& \text { KR }(\%)=\frac{\text { Jumlah Kerapatan Suatu Jenis }}{\text { Jumlah Kerapatan Seluruh Jenis }} \times 100 \% \\
& \text { Frekuensi }=\frac{\text { Jumlah Sampling Unit Ditemukan suatu Jenis }}{\text { Jumlah Seluruh Sampling Unit }} \times 100 \% \\
& \mathrm{FR}(\%)=\frac{\text { Jumlah Frekuensi suatu Jenis }}{\text { Jumlah Nilai Frekuensi Seluruh Jenis }} \times 100 \% \\
& \text { Dominansi }=\frac{\text { Jumlah Basal Area suatu Jenis }}{\text { Jumlah Seluruh Sampling Area }} \times 100 \% \\
& \operatorname{DR}(\%)=\frac{\text { Nilai Dominasi Suatu Jenis }}{\text { Jumlah Nilai Dominansi Seluruh Jenis }} \times 100 \%
\end{aligned}
$$

dimana INP adalah Indeks Nilai Penting, KR adalah Kerapatan Relatif, FR adalah Frekuensi Relatif, DR adalah Dominansi Relatif, H' adalah Indeks Keanekaragaman Jenis Shannon-Wienner, R' adalah Indeks Kekayaan Jenis Margalef, CN adalah Indeks Kesamaan Jenis Sorrensen Kualitatif, ni adalah 
Jumlah Individu Tiap Jenis, N adalah Jumlah Total Seluruh populasi, S adalah Jumlah Jenis,Ln adalah Logaritma Natural, $\mathrm{Na}$ adalah Jumlah populasi di lokasi a, $\mathrm{Nb}$ adalah jumlah poopulasi di lokasi b, 2jN adalah jumlah terendah dari dua populasi jenis antara kedua lokasi.

Besarnya Indeks Keanekaragaman Jenis menurut Shannon-Wienner didefinisikan sebagai berikut:

- Nilai H'> 3 menunjukkan keanekaragaman jenis pada suatu transek adalah melimpah tinggi.

- Nilai H' $1 \leq \mathrm{H} \leq 3$ menunjukkan keanekaragaman jenis pada suatu transek adalah melimpah sedang.

- Nilai H’ < 1 menunjukkan keanekaragaman jenis pada suatu transek adalah rendah atau sedikit. Sementara itu besarnya indeks kekayaan Margalef didefinisikan sebagai berikut:

- Nilai R'> 5 menunjukkan kekayaan jenis tinggi

- Nilai R' 3,5 $\leq \mathrm{H} \leq 5$ menunjukkan kekayaan jenis sedang

- Nilai R' $<3,5$ menunjukkan kekayaan jenis rendah.

Kajian pemanfaatan jenis pohon oleh masyarakat lokal dilakukan melalui wawancara dan kuisioner pada 29 petani pemilik lahan agroforestry. Informasi yang digali dari responden antara lain informasi umum mengenai data diri responden (usia, tingkat pendidikan, pekerjaan), aset lahan pertanian yang dikuasai/dimiliki, teknik budidaya dan pengelolaan komoditas kehutanan dan pertanian, serta pemanfaatan biodiversitas (khususnya flora) yang selama ini dilakukan. Jenis pemanfaatan biodiversitas dikelompokkan berdasarkan pemanfaatannya sebagai bahan serat/pakaian, makanan, obat-obatan, bahan bangunan, peralatan rumah tangga, racun, kayu bakar, perahu, pengendali erosi/banjir, dan budaya. Hasil data dan informasi yang diperoleh ditabulasi dan dideskripsikan secara naratif.

Jumlah responden merupakan keterwakilan dari desa di hulu, tengah dan hilir DAS Balantieng. Jumlah responden di Desa Kindang, Bululohe, dan Swatani yang mewakili wilayah hulu, tengah dan hilir DAS Balantieng berturut turut adalah sebanyak 10, 10 dan 9 responden. Jumlah responden lakilaki dan perempuan berturut-turut adalah sebesar 19 dan 10 orang dengan usia antara $30-64$ tahun. Tingkat pendidikan responden antara SD hingga sarjana dengan mayoritas tingkat pendidikan yaitu SLTA yaitu sebesar $45 \%$.

\section{Hasil dan Pembahasan}

\subsection{Kondisi Umum Lokasi Penelitian}

Kabupaten Bulukumba terletak di bagian selatan Pulau Sulawesi dan berjarak kurang lebih 153 kilometer dari ibukota Propinsi Sulawesi Selatan, Makassar. Terletak antara $05^{\circ} 20-05^{\circ} 40$ lintang selatan dan $119^{\circ} 58-120^{\circ} 28$ bujur timur. Kabupaten Bulukumba terdiri dari 10 kecamatan, yaitu: 
Kajang, Bulukumpa, Rilau Ale, Kindang, Gantarang, Bontobahari, Herlang, Ujung Bulu, Ujung Loe dan Bontotiro yang terbagi ke dalam 27 kelurahan dan 103 desa dengan total luas $1.154,7 \mathrm{~km}^{2}$. Kabupaten Bulukumba memiliki batas administrasi sebelah Utara; Kabupaten Sinjai, sebelah Timur; Teluk Bone, sebelah Selatan; Laut Flores dan sebelah Barat; Kabupaten Bantaeng (BPS Kabupaten Bulukumba, 2012).

Wilayah Kabupaten Bulukumba hampir 95,4 persen berada pada ketinggian 0 sampai dengan 1000 meter di atas permukaan laut (dpl) dengan tingkat kemiringan tanah umumnya $0-40^{\circ}$. Terdapat sekitar 32 aliran sungai yang dapat mengairi sawah seluas 23.365 ha, sehingga merupakan daerah potensi pertanian. Curah hujannya rata-rata $152 \mathrm{~mm} /$ bulan $(1.824 \mathrm{~mm} /$ tahun $)$ dan rata-rata hari hujan 10 hari per bulan (BPS Kabupaten Bulukumba, 2012).

Penduduk Kabupaten Bulukumba tahun 2011 berjumlah 398.531 jiwa, sebanyak 211.092 jiwa perempuan dan 187.439 jiwa laki-laki. Kepadatanpenduduk Kabupaten Bulukumba pada tahun 2011 yaitu 345 orang per $\mathrm{km}^{2}$ dan luas tutupan hutan $8.471,5$ ha atau $67,46 \%$ dari total luas daratan. Jumlah angkatan kerja sebanyak 169.567 jiwa, dengan mayoritas bekerja pada sektor pertanian (58,5\%), disusul perdagangan, rumah makan, dan hotel (14,4\%), jasa kemasyarakatan (10,5\%), industri pengolahan (8,2\%) dan lain-lain (8,3\%) (BPS Kabupaten Bulukumba, 2012).

Komoditi unggulan dari Kabupaten Bulukumba adalah dari sektor perkebunan, yang terdiri dari kelapa, cengkeh, kopi, lada/merica dan coklat/kakao, sedangkan komoditi karet dikelola oleh pihak swasta. Jumlah produksi dan luas perkebunan yang ada di Kabupaten Bulukumba dapat dilihat pada Tabel 3.1.

Tabel 3.1 Jumlah produksi dan luas perkebunan di Kabupaten Bulukumba

\begin{tabular}{lrrrrrrr}
\hline Total & Karet & Kelapa & Cengkeh & Kopi & Lada & Coklat & Lainnya \\
\hline Luas (ha) & 0 & 12.205 & 4.648 & 5.197 & 2.350 & 7.253 & 7.840 \\
\hline Produksi (ton) & 0 & 217 & 17 & 207 & 45 & 603 & 41 \\
\hline
\end{tabular}

Sumber: BPS Kabupaten Bulukumba (2012) dengan modifikasi

Kegiatan penelitian "Kuantifikasi Jasa Lingkungan Air dan Karbon Pola Agroforestri pada Hutan Rakyat di Wilayah DAS Jeneberang” dilaksanakan di DAS Balangtieng, yang merupakan salah satu DAS di Wilayah Sungai (WS) Jeneberang. DAS Balantieng yang mempunyai luas sekitar 202,35 km², di mana secara geografis terletak pada $121^{\circ} \mathrm{BT}$ dan $5^{\circ} 25^{\prime}$ LS. Secara administratif terletak pada 4 Kabupaten di Propinsi Sulawesi Selatan, yaitu Bulukumba, Bantaeng, Gowa dan Sinjai yang meliputi 37 desa dalam 6 kecamatan. Kecamatan-kecamatan tersebut yaitu Bulukumba, Gantarang Kindang, Ujung Bulu, Bissapu, Tompobulu dan Sinjai Barat. 


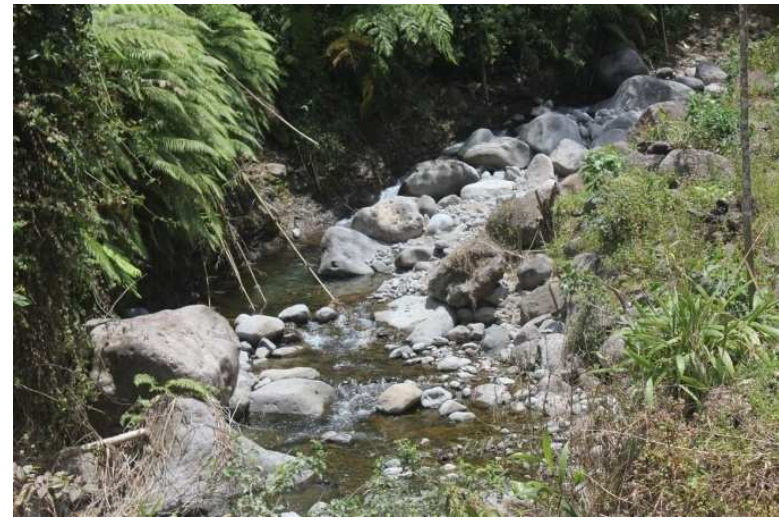

A

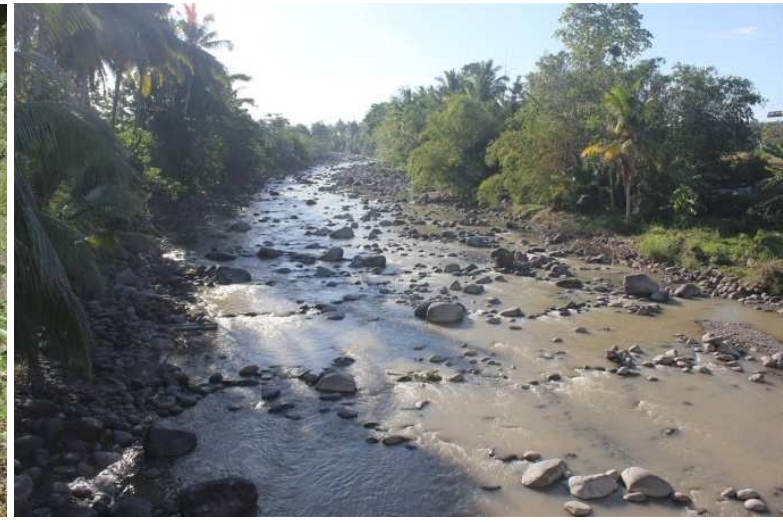

B

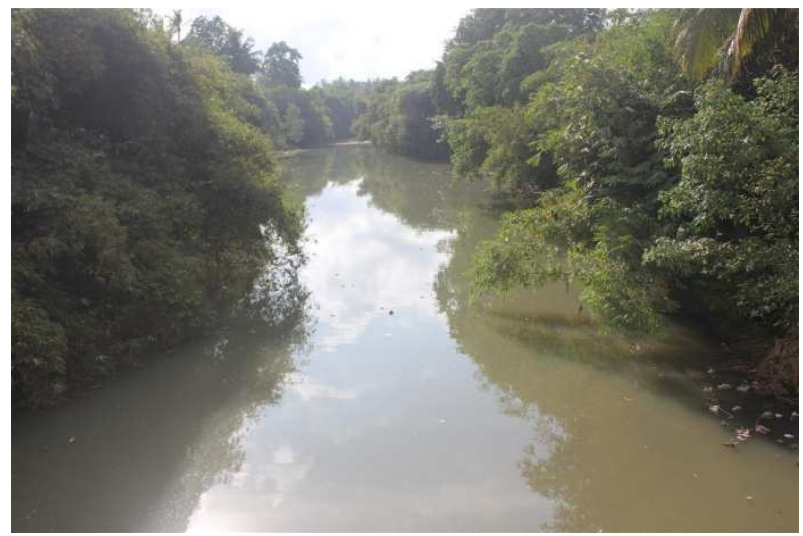

C

Gambar 3.1 Kondisi sungai utama DAS Balangtieng bagian hulu (A), tengah (B) dan hilir (C)

Kelas kelerengan DAS Balantieng, yang mempunyai panjang sungai utama sekitar 53,39 km, beragam dari kelas I sampai V. Kelas I menempati wilayah paling luas yaitu $60,93 \%$ dari luas DAS, diikuti kelas II sebesar 13,2 \%, kelas V sebesar 11,83 \%, kelas III sebesar 7,55 \% dan kelas IV sebesar 6,49 $\%$.

Tabel 3.2 Pembagian luas DAS Balantieng menurut kelas kelerengan

\begin{tabular}{lllllc|c}
\hline \multirow{2}{*}{ No } & \multirow{2}{*}{ Kemiringan } & \multirow{2}{*}{ Kelas } & & \multicolumn{2}{c}{ Luas } \\
\cline { 5 - 6 } & & & & $\mathbf{K m}^{2}$ & $\%$ \\
\hline 1 & $0-8 \%$ & I & Datar - berombak & 123,29 & 60,93 \\
2 & $8-15 \%$ & II & Berombak - bergelombang & 26,71 & 13,20 \\
3 & $15-25 \%$ & III & Bergelombang- berbukit & 15,28 & 7,55 \\
4 & $25-40 \%$ & IV & Berbukit - bergunung & 13,12 & 6,49 \\
5 & $>40 \%$ & V & Bergunung curam & & 23,94 & 11,83 \\
\hline & & & & Jumlah & $\mathbf{2 0 2 , 3 5}$ & $\mathbf{1 0 0}$ \\
\hline
\end{tabular}


DAS Balantieng terdiri dari 3 ordo tanah yaitu Inseptisol, Entisol dan Andisol. Dari 3 ordo yang tersebar pada DAS Balantieng terdapat 2 ordo yang mendominasi yaitu Inseptisol dengan luas 43,73 $\%$ dari luas DAS dan Entisol sekitar 40,70 \% luas DAS.

Tabel 3.3 Pembagian luas DAS Balantieng menurut Ordo tanah

\begin{tabular}{|c|c|c|c|}
\hline \multirow{2}{*}{ No } & \multirow{2}{*}{ Ordo } & \multicolumn{2}{|c|}{ Luas } \\
\hline & & $\mathrm{Km}^{2}$ & $\%$ \\
\hline 1 & Andisol & 31,52 & 15,58 \\
\hline 2 & Entisol & 82,35 & 40,70 \\
\hline 3 & Inseptisol & 88,48 & 43,73 \\
\hline & Jumlah & 202,35 & 100 \\
\hline
\end{tabular}

Secara umum DAS Balantieng berdasarkan klasifikasi iklim menurut Mohr (1993) masuk dalam golongan daerah agak basah (golongan II) dan berdasarkan klasifikasi Schmidt-Ferguson (1951) termasuk golongan B (basah). Berdasarkan data curah hujan tahun 1990 - 2010 dan data stasiun Matajang pada tahun 1990 - 2010, curah hujan tahunan di DAS Balantieng bervariasi antara 1.581 $5.032 \mathrm{~mm}$ per tahun dengan rata-rata curah hujan $2.270 \mathrm{~mm}$ per tahun. Curah hujan harian tertinggi berkisar antara $56-151 \mathrm{~mm}$ per hari. Balantieng mempunyai perbedaan kondisi musim basah dan musim kering yang jelas, dimana sekitar 75\% musim basah terjadi pada Bulan November sampai Juli, sedangkan pada musim kering terjadi pada Bulan Agustus -Oktober. Potensi evapotranspirasi rata-rata (evapotranspiration) sebesar $1.739 \mathrm{~mm}$ per tahun.

\subsection{Komposisi Jenis dan Struktur Vegetasi}

Hasil analisis vegetasi beberapa pola agroforestry di sekitar DAS Balangtieng menunjukkan secara umum terdapat tujuh pola agroforestri dominan meliputi pola agroforestry berbasis kelapa, jambu mete, coklat, cengkeh, kopi, kebun campuran dan agroforestry di hutan lindung. Secara umum komposisi jenis seluruh pola tersusun atas 112 jenis tumbuhan (11 jenis tidak teridentifikasi) meliputi 109 jenis pohon, 1 jenis liana, 1 jenis herba, 1 jenis pandan dan 1 jenis paku. sebagian besar pohon tergolong pohon buah (HHBK Buah).

Terdapat perbedaan tipe SPL Agroforestry jika ditinjau dari aspek lanskap. Berdasarkan tipe SPL di daerah hulu terdiri atas SPL agroforestry kopi, cengkeh dan kebun campuran serta agroforestry di hutan sekunder, sedangkan di daerah tengah meliputi SPL coklat, cengkeh, kebun campuran serta hutan sekunder. Sementara itu tipe SPL agroforestry di daerah hilir meliputi kelapa, jambu mete dan kebun campuran. Tipe agroforestry kebun campuran cenderung tersebar sepanjang DAS dan menjadi kantong-kantong keragaman hayati tumbuhan.

Adapun struktur vegetasi setiap SPL agroforestry di sekitar DAS Balangtieng berbeda antar SPL bergantung pada tingkat pengelolaan dan lanskap. Struktur vegetasi pada setiap SPL menunjukkan tingkat regenerasi biodiversitas tumbuhan dan strata relung ekologis. 


\section{Agroforestry Kelapa}

Kelapa (Cocos nucifera) merupakan salah satu komoditi penting yang banyak dikembangkan oleh masyarakat di wilayah dataran rendah khususnya sekitar pantai termasuk di Kabupaten Bulukumba dan menjadi komoditi perkebunan utama kedua setelah coklat (BPS Kabupaten Bulukumba 2015). Pengembangan tanaman kelapa biasanya dilakukan dengan pola tanam monokultur, polikultur dan agroforestry baik sebagai komponen utama ataupun tambahan sebagaimana terjadi di Riau (Damanik, 2007) dan Yogyakarta (Hani and Suryanto 2014).

Adapun agroforestry kelapa di sekitar DAS Balangtieng tersusun atas 26 jenis tumbuhan meliputi 13 jenis semai, 5 jenis sapihan, 6 jenis pancang dan 15 jenis pohon (Tabel 3.4). Berdasarkan komposisi floristik secara umum, agroforestry kelapa tersusun atas jenis-jenis tumbuhan yang tergolong pohon baik jenis yang secara sengaja ditanam ataupun tumbuh secara liar dan dibiarkan berkembang secara alami karena masih memberikan manfaat lain bagi pemilik kebun. Sebagian besar jenis tumbuhan penyusun agroforestry kelapa tergolong Hasil Hutan Bukan Kayu (HHBK) buah-buahan. Disamping itu pada agroforestri kelapa masih dijumpai jenis tumbuhan yang endemik dan menjadi tumbuhan penting di Kabupaten Bulukumba yaitu Biti (Vitex cofassus) meskipun kerapatan pohonnya sangat rendah (1,25 Individu/ha) namun pada tingkat semai mencapai 375 individu/ha. Kondisi biti tersebut tergolong jarang dan baru berkembang secara alami sehingga pada tingkat pertumbuhan sapihan dan pancang tidak dijumpai.

Tabel 3.4 Kerapatan populasi spesies tumbuhan berdasarkan tingkat pertumbuhan pada agroforestry kelapa di sekitar DAS Balangtieng Kabupaten Bulukumba

\begin{tabular}{|c|c|c|c|c|c|c|c|}
\hline \multirow{2}{*}{ No } & \multirow{2}{*}{ Nama Lokal } & \multirow{2}{*}{ Nama Latin } & \multicolumn{4}{|c|}{ Kerapatan populasi (individu/ha) } & \multirow{2}{*}{ Kategor } \\
\hline & & & Semai & Sapihan & Pancang & Pohon & \\
\hline 1 & Terep & Artocarpus elasticus & - & - & - & 1,25 & HG \\
\hline 2 & Asem Jawa & Tamarindus indicus & - & - & - & 1,25 & $\mathrm{HB}$ \\
\hline 3 & Biti & Vitex cofassus & 375 & - & - & 1,25 & $\mathrm{KA}$ \\
\hline 4 & Buni & Antidesma bunius & 125 & - & - & 1,25 & $\mathrm{HB}$ \\
\hline 5 & Coklat & Theobroma cacao & 250 & 0,2 & 20 & 46,25 & $\mathrm{PC}$ \\
\hline 6 & Duwet & Syzigium cuomini & - & - & - & 1,25 & $\mathrm{HB}$ \\
\hline 7 & Ficus & Ficus septica & 125 & - & - & & $\mathrm{KA}$ \\
\hline 8 & Gempol & Nauclea orientalis & - & - & - & 2,5 & $\mathrm{KA}$ \\
\hline 9 & Jambu Air & Eugenia sp. & - & - & - & 1,25 & $\mathrm{HB}$ \\
\hline 10 & Jambu Batu & Psidium guajava & 375 & - & - & & $\mathrm{HB}$ \\
\hline 11 & Jambu Bol & Syzygium malaccense & - & 0,2 & - & - & $\mathrm{HB}$ \\
\hline 12 & Jati & Tectona grandis & 250 & - & - & - & $\mathrm{K}$ \\
\hline 13 & Jeruk & Citrus $s p$ & - & - & 1 & - & - \\
\hline 14 & Kelapa & Cocos nucifera & - & - & - & 142,5 & HP \\
\hline 15 & Kenari & Canarium commune & - & - & - & 2,5 & $\mathrm{KA}$ \\
\hline 16 & Lamtoro & Leucaena leucocephala & 750 & 0,6 & - & - & MPTS \\
\hline 17 & Mangga & Mangifera indica & - & - & - & 15 & $\mathrm{HB}$ \\
\hline
\end{tabular}




\begin{tabular}{lllccccc}
\hline \multirow{2}{*}{ No } & \multirow{2}{*}{ Nama Lokal } & Nama Latin & \multicolumn{3}{c}{ Kerapatan populasi (individu/ha) } & Kategori \\
\cline { 3 - 6 } & & Semai & Sapihan & Pancang & Pohon & \\
\hline 18 & Mangga Macan & Mangifera indica & - & - & - & 1,25 & HB \\
19 & Mengkudu & Morinda citrifolia & 125 & - & - & - & HB \\
\hline 20 & Mete & Anacardium occidentale & 875 & - & 2 & 57,5 & HB \\
\hline 21 & Nangka & Artocarpus heterophyllus & 16.625 & - & - & 10 & HB \\
\hline 22 & Nyamplung & Calophylum inophyllum & 375 & 0,2 & 1 & - & HM \\
\hline 23 & Rambutan & Nephelium lapaceum & 250 & 2,2 & 4 & - & HB \\
\hline 24 & Spatodea & Spatodeacampanulata & 125 & - & - & - & MPTS \\
\hline 25 & Sukun & Artocarpus altilis & - & - & 3 & 8,75 & HB \\
\hline
\end{tabular}

Keterangan: HB = HHBK Buah; HP = HHBK Pati; HM = HHBK Minyak; HG = HHBK Getah; MPTS = Multipurpose Tree Species; K = Kayu Pertukangan; KA = Kayu Alam; PC = Perenial Crop

Secara umum struktur vegetasi agroforestry kelapa di DAS Balangtieng menunjukkan kondisi yang kurang sehat khususnya ditunjukkan dengan sebaran kerapatan jenis pada setiap tingkat pertumbuhan yang tidak merata (Tabel 1) atau menunjukkan proses regenerasi yang tidak sehat. Hanya satu jenis tumbuhan yang tersebar di setiap tingkat pertumbuhan yaitu coklat. Sebaran jenis tumbuhan lebih banyak pada tingkat pertumbuhan semai dan pohon, sedangkan pada tingkat sapihan dan pancang lebih sedikit.

Jenis tumbuhan pada tingkat semai didominasi oleh nangka (INP 99,65 \%) dengan nilai indeks penting berbeda jauh dengan jenis lainnya termasuk tidak dijumpainya semai kelapa. Hal ini disebabkan pengelolaan lahan yang tidak intensif sehingga buah nangka tua yang jatuh dibiarkan berproses secara alami hingga tumbuhnya semai nangka dalam jumlah banyak dan tidak dibersihkan atau dipindahkan. selian itu kepadatan semua tumbuhan pada tingkat semai cukup tinggi dibandingkan tingkat pertumbuhan diatasnya yaitu mencapai 20.625 individu/ha. Sementara itu tidak dijumpai semai kelapa pada plot penelitian disebabkan pemanfaatan buah kelapa cukup intensif atau tidak meninggalkan buah kelapa yang jatuh hingga tumbuh secara alami di bawah tegakan kelapa. Intensifnya pemanfaatan buah kelapa disebabkan kelapa merupakan salah satu komoditi utama perkebunan di Kabupaten Bulukumba dengan jumlah produksi pada tahun 2014 mencapai 3.692 ton dan meningkat dari tahun 2013 sebesar 36,5\% (BPS Kabupaten Bulukumba 2015). Secara umum sebagian besar jenis tumbuhan pada tingkat semai tergolong kategori tanaman buah-buahan yang ditanam oleh pemilik lahan meskipun terdapat pula jenis yang tumbuh secara liar dan dibiarkan seperti jenis Spatodea dan lamtoro karena adanya manfaat dari tumbuhan tersebut sepeti lamtoro sebagai pakan ternak serta Spatodea sebagai pembatas lahan.

Jenis tumbuhan pada tingkat sapihan lebih sedikit dibandingkan pada tingkat semai. Jenis tumbuhan yang mendominasi pada tingkat sapihan adalah rambutan (INP 107,56 \%). Sementara itu jenis tumbuhan yang mendominasi pada tingkat pancang adalah coklat dengan nilai INP 183,85\%. Selain itu, coklat dijumpai pula pada tingkat pertumbuhan semai dan sapihan meskipun tidak mendominasi. Hasil analisis vegetasi tersebut menunjukkan bahwa jenis coklat menjadi penyusun utama agroforestry kelapa pada strata bawah atau dipilih oleh masyarakat sebagai tanaman bawah (Gambar 
3.2). Terpilihnya coklat sebagai tanaman bawah pada tegakan kelapa disebabkan pertimbangan produktivitas lahan karena coklat termasuk jenis komoditi perkebunan utama di Kabupaten Bulukumba sehingga dominasi coklat pada tingkat pancang menunjukkan pada pola agroforestry kelapa belum terlalu lama dilakukan introduksi atau penanaman coklat dengan diameter coklat masih berkisar $5-10 \mathrm{~cm}$.

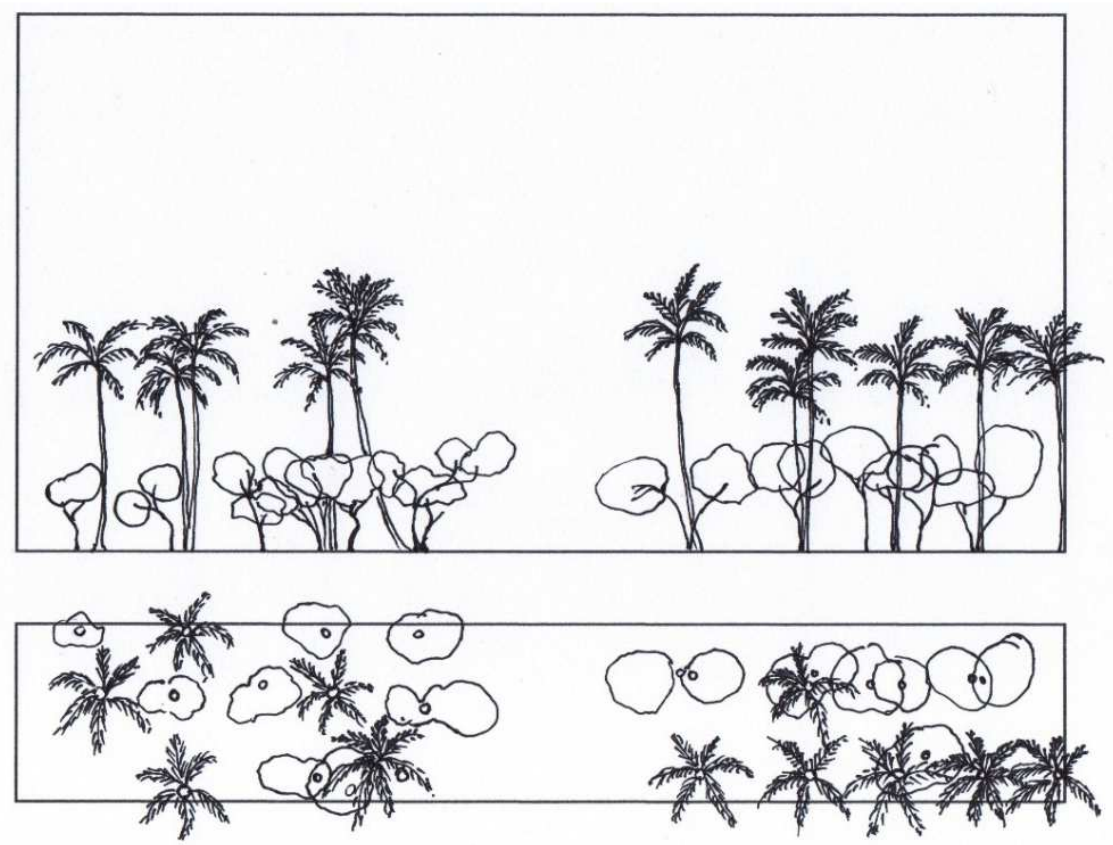

Gambar 3.2 Diagram profil tegakan pada sistem agroforestry kelapa+coklat

Adapun jenis tumbuhan pada tingkat pohon lebih banyak berdasarkan komposisi jenis dengan dominasi jenis kelapa (INP 141,37 \%) dan kerapatan 142,5 individu/ha. Jenis lain yang dijumpai cukup banyak adalah jambu mete dan coklat yang menunjukkan bahwa kombinasi jenis agroforestry kelapa di sekitar DAS Balangtieng sebagian besar dengan coklat dan jambu mete atau kombinasi antara tanaman tahunan dengan tanaman MPTS khususnya buah-buahan (46,15\%), sedangkan kombinasi kelapa dengan tanaman semusim tidak dijumpai secara masif kecuali pada satu plot yang ditanam tidak secara intensif yaitu jenis terong.

Tabel 3.5 Struktur Vegetasi dan Indeks Nilai Penting Agroforestry Kelapa di sekitar DAS Balangtieng Kabupaten Bulukumba

\begin{tabular}{lllllllll} 
No & \multicolumn{1}{c}{ Jenis } & $\begin{array}{c}\mathrm{K} \\
(\mathrm{Ind} . / \mathrm{Ha})\end{array}$ & $\begin{array}{c}\mathrm{KR} \\
(\%)\end{array}$ & $\mathrm{F}$ & $\begin{array}{c}\mathrm{FR} \\
(\%)\end{array}$ & $\begin{array}{c}\mathrm{D} \\
\left(\mathrm{m}^{2} / \mathrm{Ha}\right)\end{array}$ & $\begin{array}{c}\text { DR } \\
(\%)\end{array}$ & $\begin{array}{c}\text { INP } \\
(\%)\end{array}$ \\
\hline Semai & & & & & & & & \\
1 & Biti & 375 & 1,82 & 0,05 & 4,76 & - & - & 6,58 \\
2 & Buni & 125 & 0,61 & 0,05 & 4,76 & - & - & 5,37 \\
3 & Coklat & 250 & 1,21 & 0,05 & 4,76 & - & - & 5,97 \\
4 & Ficus Septica & 125 & 0,61 & 0,05 & 4,76 & - & - & 5,37 \\
5 & Jambu Batu & 375 & 1,82 & 0,05 & 4,76 & - & - & 5,97 \\
6 & Jati & 250 & 1,21 & 0,05 & 4,76 & - & - & 5,97 \\
\hline
\end{tabular}




\begin{tabular}{|c|c|c|c|c|c|c|c|c|}
\hline No & Jenis & $\begin{array}{c}\mathrm{K} \\
\text { (Ind./Ha) }\end{array}$ & $\begin{array}{l}\mathrm{KR} \\
(\%)\end{array}$ & $F$ & $\begin{array}{l}\text { FR } \\
(\%)\end{array}$ & $\begin{array}{c}D \\
\left(\mathrm{~m}^{2} / \mathrm{Ha}\right)\end{array}$ & $\begin{array}{l}\text { DR } \\
(\%)\end{array}$ & $\begin{array}{l}\text { INP } \\
(\%)\end{array}$ \\
\hline 7 & Lamtoro & 750 & 3,64 & 0,05 & 4,76 & - & - & 8,40 \\
\hline 8 & Mengkudu & 125 & 0,61 & 0,05 & 4,76 & - & - & 5,37 \\
\hline 9 & Jambu Mete & 875 & 4,24 & 0,20 & 19,05 & - & - & 23,29 \\
\hline 10 & Nangka & 16.625 & 80,61 & 0,20 & 19,05 & - & - & 99,65 \\
\hline 11 & Nyamplung & 375 & 1,82 & 0,10 & 9,52 & - & - & 11,34 \\
\hline 12 & Rambutan & 250 & 1,21 & 0,05 & 4,76 & - & - & 5,97 \\
\hline \multirow[t]{2}{*}{13} & Spatodea & 125 & 0,61 & 0,05 & 4,76 & - & - & 5,37 \\
\hline & Jumlah & 20.625 & 100,00 & 1,05 & 100,00 & - & & 200,00 \\
\hline \multicolumn{9}{|c|}{ Sapihan } \\
\hline 1 & Coklat & 0,20 & 5,88 & 0,05 & 14,29 & - & - & 20,17 \\
\hline 2 & Jambu Bol & 0,20 & 5,88 & 0,05 & 14,29 & - & - & 20,17 \\
\hline 3 & Lamtoro & 0,60 & 17,65 & 0,05 & 14,29 & - & - & 31,93 \\
\hline 4 & Nyamplung & 0,20 & 5,88 & 0,05 & 14,29 & - & - & 20,17 \\
\hline \multirow[t]{2}{*}{5} & Rambutan & 2,20 & 64,71 & 0,15 & 42,86 & - & - & 107,56 \\
\hline & Jumlah & 3,40 & 100,00 & 0,35 & 100,00 & - & - & 200,00 \\
\hline \multicolumn{9}{|c|}{ Pancang } \\
\hline 1 & Coklat & 1.00 & 64.52 & 0,50 & 52,63 & 0,45 & 66,70 & 183,85 \\
\hline 2 & Jeruk & 0.05 & 3.23 & 0,05 & 5,26 & 0,02 & 2,63 & 11,12 \\
\hline 3 & Jambu Mete & 0.10 & 6.45 & 0,10 & 10,53 & 0,05 & 6,91 & 23,89 \\
\hline 4 & Nyamplung & 0.05 & 3.23 & 0,05 & 5,26 & 0,01 & 1,53 & 10,01 \\
\hline 5 & Rambutan & 0.20 & 12.90 & 0,15 & 15,79 & 0,10 & 15,54 & 44,23 \\
\hline \multirow[t]{2}{*}{6} & Sukun & 0.15 & 9.68 & 0,10 & 10,53 & 0,04 & 6,71 & 26,91 \\
\hline & Jumlah & 1.55 & 100.00 & 0,95 & 100,00 & 0,67 & 100,02 & 300,02 \\
\hline \multicolumn{9}{|c|}{ Pohon } \\
\hline 1 & Artocarpus Sp & 1,25 & 0,43 & 0,05 & 1,54 & 0,01 & 0,08 & 2,05 \\
\hline 2 & Asem Jawa & 1,25 & 0,43 & 0,05 & 1,54 & 0,33 & 2,03 & 4,00 \\
\hline 3 & Biti & 1,25 & 0,43 & 0,05 & 1,54 & 0,01 & 0,06 & 2,03 \\
\hline 4 & Buni & 1,25 & 0,43 & 0,05 & 1,54 & 0,20 & 1,21 & 3,17 \\
\hline 5 & Coklat & 46,25 & 15,74 & 0,55 & 16,92 & 0,63 & 3,85 & 36,52 \\
\hline 6 & Duwet & 1,25 & 0,43 & 0,05 & 1,54 & 0,14 & 0,83 & 2,80 \\
\hline 7 & Gempol & 2,50 & 0,85 & 0,10 & 3,08 & 0,25 & 1,55 & 5,48 \\
\hline 8 & Jambu Air & 1,25 & 0,43 & 0,05 & 1,54 & 0,34 & 2,08 & 4,04 \\
\hline 9 & Kelapa & 142,50 & 48,51 & 1,00 & 30,77 & 10,17 & 62,09 & 141,37 \\
\hline 10 & Kenari & 2,50 & 0,85 & 0,10 & 3,08 & 0,12 & 0,72 & 4,64 \\
\hline 11 & Mangga & 15,00 & 5,11 & 0,30 & 9,23 & 0,70 & 4,28 & 18,62 \\
\hline 12 & Mangga Macan & 1,25 & 0,43 & 0,05 & 1,54 & 0,01 & 0,06 & 2,03 \\
\hline 13 & Jambu Mete & 57,50 & 19,57 & 0,45 & 13,85 & 1,14 & 6,95 & 40,37 \\
\hline 14 & Nangka & 10,00 & 3,40 & 0,20 & 6,15 & 0,47 & 2,86 & 12,42 \\
\hline \multirow[t]{2}{*}{15} & Sukun & 8,75 & 2,98 & 0,20 & 6,15 & 1,86 & 11,34 & 20,47 \\
\hline & Jumlah & 293,8 & 100 & 3,25 & 100,00 & 16,38 & 100,00 & 300,00 \\
\hline
\end{tabular}

Keterangan: K = Kerapatan; KR = Kerapatan Relatif; F = Frekuensi; FR = Frekuensi Relatif; D = Dominansi; $\mathrm{DR}=$ Dominansi Relatif; INP = Indek Nilai Penting 
Secara umum terdapat fenomena menarik dari Tabel 3.5 terutama berkaitan dengan nilai dominasi tumbuhan strata di bawah kelapa yaitu coklat pada tingkat pancang dan jambu mete pada tingkat pohon. Fenomena ini menunjukkan pada SPL kelapa kemungkinan akan terjadi pergeseran tanaman strata bawah dari jambu mete menuju coklat yang ditunjukkan dengan dominasi coklat pada tingkat pancang atau pohon kecil.

\section{Agroforestry Jambu Mete}

Jambu mete merupakan jenis komoditi yang banyak ditanam secara intensif oleh masyarakat di wilayah hilir DAS Balangtieng. Intensitas pengelolaan jambu mete terlihat dari minimnya jenis tumbuhan lain pada lokasi plot penelitian. Adanya kecenderungan masyarakat untuk menanam dan mengelola jambu mete secara intensif menyulitkan peneliti untuk mendapatkan pola tanam jambu mete secara agroforestry komplek sehingga hanya agroforestry sederhana jambu mete yang dijumpai disekitar DAS Balangtieng.

Tabel 3.6 Kerapatan populasi jenis tumbumbuhan berdasarkan tingkat pertumbuhan pada agroforestry Jambu Mete di sekitar DAS Balangtieng Kabupaten Bulukumba

\begin{tabular}{|c|c|c|c|c|c|c|c|}
\hline \multirow{2}{*}{ No } & \multirow{2}{*}{ Nama Lokal } & \multirow{2}{*}{ Nama Latin } & \multicolumn{4}{|c|}{ Kepadatan populasi (Individu/ha) } & \multirow{2}{*}{ Kategor } \\
\hline & & & Semai & Sapihan & Pancang & Pohon & \\
\hline 1 & Biti & Vitex cofassus & - & - & - & 2,5 & $\mathrm{KA}$ \\
\hline 2 & Coklat & Theobroma cacao & - & - & - & 2,5 & PC \\
\hline 3 & Lowa & Ficus sp & - & - & 7,5 & - & $\mathrm{KA}$ \\
\hline 4 & Jambu Mete & Anacardium occidentale & 250 & - & 107,5 & 292,5 & $\mathrm{HB}$ \\
\hline 5 & Jati & Tectona grandis & - & - & 5 & 2,5 & $\mathrm{~K}$ \\
\hline 6 & Jeruk & Citrus sp. & - & - & 17,5 & 2,5 & $\mathrm{HB}$ \\
\hline 7 & Kelapa & Cocos nucifera & - & - & - & 77,5 & HP \\
\hline 8 & Sirsak & Annona muricata & 250 & 120 & 5 & - & $\mathrm{HB}$ \\
\hline
\end{tabular}

Keterangan: HB = HHBK Buah; HP = HHBK Pat; HM = HHBK Minyak; HG = HHBK Getah; MPTS = Multipurpose Tree Species; K = Kayu Pertukangan; KA = Kayu Alam; PC = Perenial Crop

Agroforestry sederhana jambu mete tersusun atas jenis tumbuhan yang sangat minim sebagaimana Tabel 3.6. Sebanyak 8 jenis tumbuhan diketahui tumbuh pada lokasi agroforestry jambu mete meliputi 2 jenis tergolong semai, 1 jenis sapihan, 5 jenis pancang dan 6 jenis pohon. Sebagian besar jenis pohon semuanya tergolong HHBK buah-buahan, meskipun pada tingkat pertumbuhan pohon masih dijumpai jenis khas kayu alam yaitu biti.

Tabel 3.7 Struktur Vegetasi Agroforestry Jambu Mete di sekitar DAS Balangtieng Kabupaten Bulukumba

\begin{tabular}{|c|c|c|c|c|c|c|c|c|}
\hline No & Jenis & $\begin{array}{c}\mathrm{K} \\
\text { (Ind./Ha) } \\
\end{array}$ & $\begin{array}{l}\text { KR } \\
(\%) \\
\end{array}$ & $F$ & $\begin{array}{l}\text { FR } \\
(\%) \\
\end{array}$ & $\begin{array}{c}\mathrm{D} \\
\left(\mathrm{m}^{2} / \mathrm{Ha}\right) \\
\end{array}$ & $\begin{array}{l}\text { DR } \\
(\%) \\
\end{array}$ & $\begin{array}{l}\text { INP } \\
(\%) \\
\end{array}$ \\
\hline \multicolumn{9}{|l|}{ Semai } \\
\hline 1 & Sirsak & 250 & 50 & 0,1 & 50 & - & - & 100 \\
\hline 2 & Jambu Mete & 250 & 50 & 0,1 & 50 & - & - & 100 \\
\hline & Jumlah & 500 & 100 & 0,2 & 100 & - & - & 200 \\
\hline
\end{tabular}




\begin{tabular}{|c|c|c|c|c|c|c|c|c|}
\hline \multicolumn{9}{|l|}{ Sapihan } \\
\hline 1 & Sirsak & 120 & - & - & - & - & - & - \\
\hline \multicolumn{9}{|l|}{ Pancang } \\
\hline 1 & Lowa & 7,5 & 5,26 & 0,1 & 8,33 & 0,03 & 4,55 & 18,15 \\
\hline 2 & Jati & 5 & 3,51 & 0,1 & 8,33 & 0,03 & 3,64 & 15,49 \\
\hline 3 & Jeruk & 17,5 & 12,28 & 0,1 & 8,33 & 0,06 & 8,39 & 29,01 \\
\hline 4 & Jambu Mete & 107,5 & 75,44 & 0,8 & 66,67 & 0,57 & 80,44 & 222,54 \\
\hline 5 & Sirsak & 5 & 3,51 & 0,1 & 8,33 & 0,02 & 2,98 & 14,82 \\
\hline & Jumlah & 142,5 & 100 & 1,2 & 100,00 & 0,71 & 100,00 & 300,00 \\
\hline \multicolumn{9}{|l|}{ Pohon } \\
\hline 1 & Biti & 2,5 & 0,66 & 0,10 & 4,76 & 0,03 & 0,25 & 5,67 \\
\hline 2 & Coklat & 2,5 & 0,66 & 0,10 & 4,76 & 0,02 & 0,17 & 5,59 \\
\hline 3 & Jati & 2,5 & 0,66 & 0,10 & 4,76 & 0,04 & 0,34 & 5,76 \\
\hline 4 & Jeruk & 2,5 & 0,66 & 0,10 & 4,76 & 0,02 & 0,20 & 5,62 \\
\hline 5 & Kelapa & 77,5 & 20,39 & 0,70 & 33,33 & 4,60 & 38,40 & 92,12 \\
\hline 6 & Jambu Mete & 292,5 & 76,97 & 1,00 & 47,62 & 7,26 & 60,64 & 185,23 \\
\hline & Jumlah & 380 & 100 & 2 & 100 & 12 & 100 & 300 \\
\hline
\end{tabular}

Keterangan: K = Kerapatan; KR = Kerapatan Relatif; F = Frekuensi; FR = Frekuensi Relatif; D = Dominansi; DR = Dominansi Relatif; INP = Indek Nilai Penting

Struktur vegetasi agroforestry jambu mete tergolong tidak sehat berdasarkan kurva tingkat pertumbuhan yang terlihat dari distribusi tumbuhan pada setiap tingkat pertumbuhan meskipun keberadaan jenis jambu mete cenderung merata di setiap tingkat pertumbuhan. Pada tingkat pertumbuhan semai ditemukan dua jenis tumbuhan termasuk jambu mete meskipun tidak dominan. Pada tingkat pertumbuhan sapihan hanya dijumpai satu jenis tumbuhan yaitu sirsak. Sementara itu pada tingkat pertumbuhan pancang dijumpai jenis tumbuhan lainnya selain jenis tumbuhan semai dan sapihan yaitu Ficus, Jati dan Jeruk dengan dominasi jambu mete cukup besar (INP 222,54). Demikian pula pada tingkat pertumbuhan pohon dominasi jambu mete cukup besar dengan nilai INP 185,23 dan dikombinasikan dengan kelapa (INP 92,12).

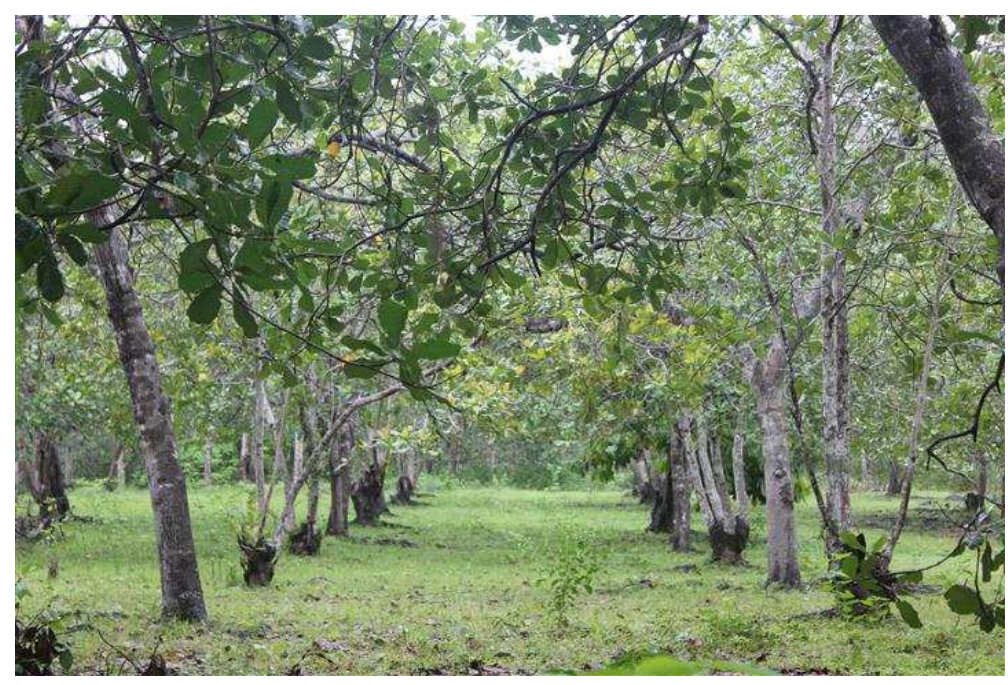

Gambar 3.3 Sistem jambu mete 


\section{Agroforestry Coklat}

Coklat (Theobroma cacao) merupakan komoditi perkebunan utama Kabupaten Bulukumba dengan kapasitas produksi pada tahun 2014 mencapai 4.881 ton (BPS Kabupaten Bulukumba 2015).

Tanaman coklat termasuk jenis yang dikembangkan dalam pola agroforestry disebabkan

kebutuhannya terhadap manajemen naungan baik untuk produktivitas maupun pengendalian hama dan penyakit (Beer et al 1998; Somarriba and Beer 2011).

Tanaman coklat di sekitar DAS Balangtieng banyak dikembangkan di wilayah tengah. Adapun komposisi floristik jenis tumbuhan pada pola agroforestry coklat lebih banyak dibandingkan agroforestry kelapa, jambu mete dan cengkeh yaitu 29 jenis tumbuhan pohon ( 1 jenis belum teridentifikasi) yang tersebar pada beberapa tingkat pertumbuhan meliputi 13 jenis tergolong semai, 7 jenis sapihan, 8 jenis pancang dan 23 jenis pohon. Jenis tumbuhan yang menjadi penyusun agroforestry coklat didominasi oleh tanaman HHBK buah-buahan selain terdapat pula jenis tanaman penghasil kayu pertukangan biti, gmelina, jati dan sengon. Sengon termasuk jenis yang tidak dijumpai pada pola agroforestry sebelumnya.

Tabel 3.8 Kkerapatan populasi jenis tumbuhan berdasarkan tingkat pertumbuhan pada agroforestry Coklat di sekitar DAS Balangtieng Kabupaten Bulukumba

\begin{tabular}{|c|c|c|c|c|c|c|c|}
\hline \multirow{2}{*}{ No } & \multirow{2}{*}{ Nama Lokal } & \multirow{2}{*}{ Nama Latin } & \multicolumn{4}{|c|}{ Kerapatan populas (ind./ha) } & \multirow{2}{*}{ Kategor } \\
\hline & & & semai & sapihan & Pancang & Pohon & \\
\hline 1 & Aren & Arenga pinata & $1.666,67$ & - & - & - & $\mathrm{HP}$ \\
\hline 2 & Biti & Vitex cofasus & - & - & 13,33 & 5,00 & K \\
\hline 3 & Blimbing Wuluh & Averrhoa bilimbi & 166,67 & - & - & - & $\mathrm{HB}$ \\
\hline 4 & Cengkeh & Syzygium aromaticum & - & 53,33 & - & - & PC \\
\hline 5 & Coklat & Theobroma cacao & $3.500,00$ & - & 326,67 & 255,5 & PC \\
\hline 6 & Dadap & Erytrina variegata & - & - & - & 6,67 & $\mathrm{KA}$ \\
\hline 7 & Durian & Durio zibhetinus & - & - & - & 6,67 & $\mathrm{HB}$ \\
\hline 8 & Ficus & Ficus nodosa & 666,67 & - & - & - & KA \\
\hline 9 & Gamal & Gliricidia maculata & - & 53,33 & 20,00 & 68,33 & MPTS \\
\hline 10 & Gmelina & Gmelina arborea & 166,67 & 26,67 & - & 11,67 & K \\
\hline 11 & Jambu & Psidium guajava & - & - & - & 1,67 & $\mathrm{HB}$ \\
\hline 12 & Jati & Tectona grandis & - & - & - & 1,67 & K \\
\hline 13 & Jeruk Bali & Citrus maxima & - & - & - & 5,00 & $\mathrm{HB}$ \\
\hline 14 & Karet & Hevea brasiliensis & 166,67 & 293,33 & 6,67 & 1,67 & HG \\
\hline 15 & Kelapa & Cocos nucifera & - & - & - & 15,00 & HP \\
\hline 16 & Kopi & Coffea sp. & $17.666,67$ & 133,33 & 33,33 & 5,00 & PC \\
\hline 17 & Lamtoro & Leucaena leucocephala & - & - & - & 1,67 & MPTS \\
\hline 18 & Langsat & Lansium domesticum & 500,00 & 106,67 & 26,67 & 13,33 & $\mathrm{HB}$ \\
\hline 19 & Mangga & Mangifera indica & - & - & - & 3,33 & $\mathrm{HB}$ \\
\hline 20 & Mete & Anacardium occidentale & - & - & - & 3,33 & $\mathrm{HB}$ \\
\hline 21 & Mojo & Crescentia cujete & 166,67 & 26,67 & 6,67 & 3,33 & MPTS \\
\hline 22 & Nangka & Artocarpus heterophyllus & - & - & - & 3,33 & $\mathrm{HB}$ \\
\hline
\end{tabular}




\begin{tabular}{|c|c|c|c|c|c|c|c|}
\hline \multirow{2}{*}{ No } & \multirow{2}{*}{ Nama Lokal } & \multirow{2}{*}{ Nama Latin } & \multicolumn{4}{|c|}{ Kerapatan populas (ind./ha) } & \multirow{2}{*}{ Kategori } \\
\hline & & & semai & sapihan & Pancang & Pohon & \\
\hline 23 & Petai & Parkia speciosa & 333,33 & - & - & 11,67 & HB \\
\hline 24 & Pulai & Alstonia scholaris & 166,67 & - & - & - & KA \\
\hline 25 & Rambutan & Nephelium lappaceum & 666,67 & - & - & 6,67 & HB \\
\hline 26 & Sengon & Falcataria moluccana & - & - & 6,67 & 10,00 & $\mathrm{~K}$ \\
\hline 27 & Sirsak & Annona muricata & 166,67 & - & - & - & $\mathrm{HB}$ \\
\hline 28 & Sp3 & - & - & - & - & 1,67 & $\mathrm{KA}$ \\
\hline 29 & Sukun & Artocarpus altilis & - & - & - & 3,33 & $\mathrm{HB}$ \\
\hline
\end{tabular}

Keterangan: $\mathrm{K}=$ Kerapatan; $\mathrm{KR}=$ Kerapatan Relatif; $\mathrm{F}=$ Frekuensi; $\mathrm{FR}=$ Frekuensi Relatif; $\mathrm{D}=$ Dominansi;

$\mathrm{DR}=$ Dominansi Relatif; INP = Indek Nilai Penting; HB = HHBK Buah; HP = HHBK Pat; HM = HHBK

Minyak; HG = HHBK Getah; MPTS = Multipurpose Tree Species; K = Kayu Pertukangan; KA = Kayu

Alam; $\mathrm{PC}=$ Perenial Crop

Struktur vegetasi agroforestry coklat secara umum tergolong tidak sehat disebabkan sebagian besar tumbuhan termasuk tingkat pertumbuhan pohon (Gambar 3.4) dan tidak dijumpai tingkat pertumbuhan lainnya kecuali jenis, karet, kopi, langsat dan mojo (Tabel 3.8). Keempat jenis tumbuhan tersebut memiliki jumlah populasi seiring dengan tingkat pertumbuhan yang baik (berbentuk $\mathrm{J}$ terbalik) atau proses regenerasinya berjalan alamiah. Hal ini menunjukkan meskipun pengelolaan agroforestry coklat cukup intensif namun masih memberikan ruang bagi jenis lain untuk tumbuh di sekitar tanaman utama.

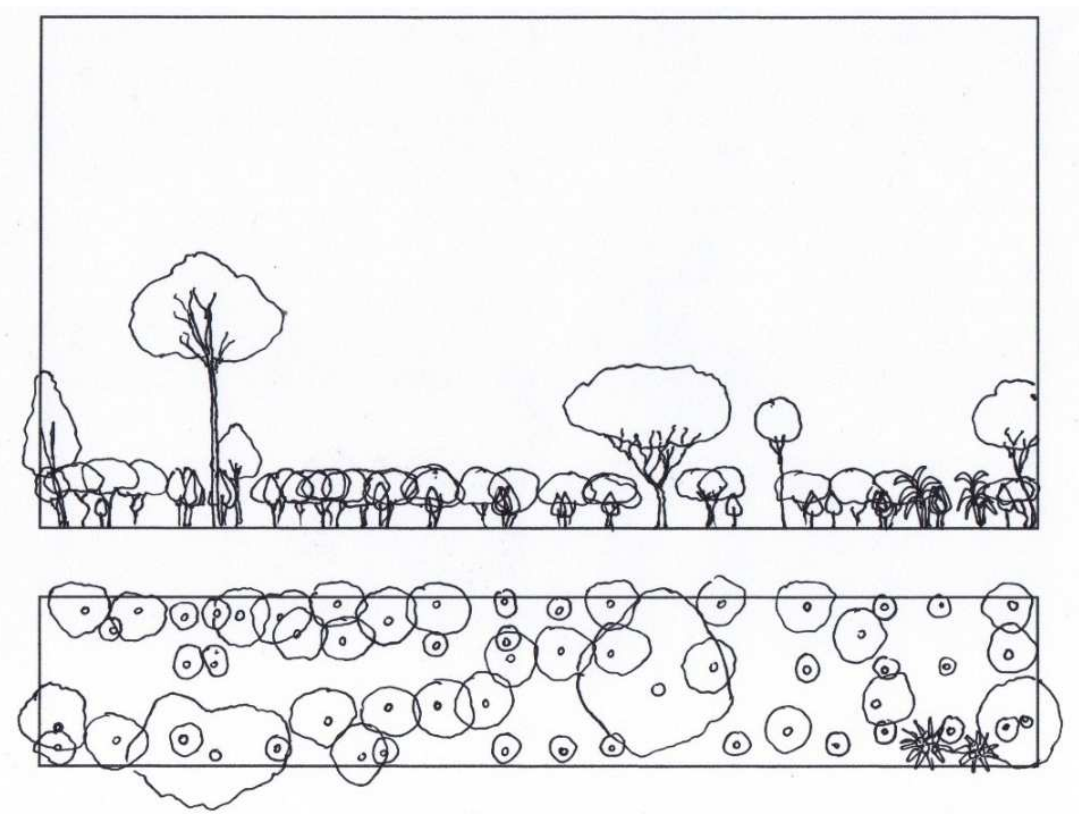

Gambar 3.4 Diagram profil tegakan pada sistem agroforestry coklat

Perbedaan agroforestry coklat dengan cengkeh adalah posisi tanaman lain selain coklat tidak hanya berada pada posisi pagar atau pembatas lahan melainkan berada di antara coklat yang berperan sebagai pemberi naungan bagi coklat dan dapat pula berperan dalam pengendalian hama yaitu membatasi pergerakan hama coklat. Pentingnya naungan bagi pertumbuhan optimum coklat dapat 
dijadikan sebagai spot biodiversitas dengan memperkaya kehadiran tumbuhan lainnya sebagai naungan coklat.

Tabel 3.9 Struktur Vegetasi Agroforestry Coklat di sekitar DAS Balangtieng Kabupaten Bulukumba

\begin{tabular}{|c|c|c|c|c|c|c|c|c|}
\hline No & Jenis & $\begin{array}{c}\mathrm{K} \\
\text { (Ind./ha) }\end{array}$ & $\begin{array}{l}\text { KR } \\
(\%) \\
\end{array}$ & $\mathrm{F}$ & $\begin{array}{l}\text { FR } \\
(\%) \\
\end{array}$ & $\begin{array}{c}\mathrm{D} \\
\left(\mathrm{m}^{2} / \mathrm{ha}\right) \\
\end{array}$ & $\begin{array}{l}\text { DR } \\
(\%) \\
\end{array}$ & $\begin{array}{l}\text { INP } \\
(\%) \\
\end{array}$ \\
\hline \multicolumn{9}{|l|}{ Semai } \\
\hline 1 & Aren & $1.666,67$ & 6,41 & 0,07 & 6,67 & - & - & 13,08 \\
\hline 2 & Blimbing Wuluh & 166,67 & 0,64 & 0,07 & 6,67 & - & - & 7,31 \\
\hline 3 & Mojo & 166,67 & 0,64 & 0,07 & 6,67 & - & - & 7,31 \\
\hline 4 & Kopi & $17.666,67$ & 67,95 & 0,20 & 20,00 & - & - & 87,95 \\
\hline 5 & Langsat & 500,00 & 1,92 & 0,07 & 6,67 & - & - & 8,59 \\
\hline 6 & Petai & 333,33 & 1,28 & 0,07 & 6,67 & - & - & 7,95 \\
\hline 7 & Pulai & 166,67 & 0,64 & 0,07 & 6,67 & - & - & 7,31 \\
\hline 8 & Rambutan & 666,67 & 2,56 & 0,07 & 6,67 & - & - & 9,23 \\
\hline 9 & Sirsak & 166,67 & 0,64 & 0,07 & 6,67 & - & - & 7,31 \\
\hline 10 & Coklat & $3.500,00$ & 13,46 & 0,07 & 6,67 & - & - & 20,13 \\
\hline 11 & Ficus nodosa & 666,67 & 2,56 & 0,07 & 6,67 & - & - & 9,23 \\
\hline 12 & Gmelina & 166,67 & 0,64 & 0,07 & 6,67 & - & - & 7,31 \\
\hline \multirow[t]{2}{*}{13} & Karet & 166,67 & 0,64 & 0,07 & 6,67 & - & - & 7,31 \\
\hline & Jumlah & $26.000,00$ & 100,00 & 1,00 & 100,00 & - & - & 200,00 \\
\hline \multicolumn{9}{|c|}{ Sapihan } \\
\hline 1 & Cengkeh & 53,33 & 7,69 & 0,13 & 10,53 & - & - & 18,22 \\
\hline 2 & Gamal & 53,33 & 7,69 & 0,07 & 5,26 & - & - & 12,96 \\
\hline 3 & Karet & 293,33 & 42,31 & 0,47 & 36,84 & - & - & 79,15 \\
\hline 4 & Kopi & 133,33 & 19,23 & 0,27 & 21,05 & - & - & 40,28 \\
\hline 5 & Langsat & 106,67 & 15,38 & 0,20 & 15,79 & - & - & 31,17 \\
\hline 6 & Mojo & 26,67 & 3,85 & 0,07 & 5,26 & - & - & 9,11 \\
\hline \multirow[t]{2}{*}{7} & Gmelina & 26,67 & 3,85 & 0,07 & 5,26 & - & - & 9,11 \\
\hline & Jumlah & 693,33 & 100,00 & 1,27 & 100,00 & - & - & 200,00 \\
\hline \multicolumn{9}{|c|}{ Pancang } \\
\hline 1 & Biti & 13,33 & 3,03 & 0,13 & 7,69 & 0,04 & 2,13 & 12,85 \\
\hline 2 & Coklat & 326,67 & 74,24 & 0,87 & 50,00 & 1,59 & 81,29 & 205,53 \\
\hline 3 & Gamal & 20,00 & 4,55 & 0,13 & 7,69 & 0,06 & 3,06 & 15,29 \\
\hline 4 & Karet & 6,67 & 1,52 & 0,07 & 3,85 & 0,01 & 0,61 & 5,97 \\
\hline 5 & Kopi & 33,33 & 7,58 & 0,20 & 11,54 & 0,11 & 5,77 & 24,89 \\
\hline 6 & Langsat & 26,67 & 6,06 & 0,20 & 11,54 & 0,08 & 3,92 & 21,52 \\
\hline 7 & Mojo & 6,67 & 1,52 & 0,07 & 3,85 & 0,02 & 1,09 & 6,45 \\
\hline \multirow[t]{2}{*}{8} & Sengon & 6,67 & 1,52 & 0,07 & 3,85 & 0,04 & 2,13 & 7,49 \\
\hline & Jumlah & 440,00 & 100,00 & 1,73 & 100,00 & 1,95 & 100,00 & 300,00 \\
\hline \multicolumn{9}{|c|}{ Pohon } \\
\hline 1 & Biti & 5,00 & 1,12 & 0,13 & 2,90 & 0,12 & 1,13 & 5,15 \\
\hline 2 & Coklat & 255,00 & 57,30 & 1,00 & 21,74 & 3,29 & 29,79 & 108,84 \\
\hline 3 & Dadap & 6,67 & 1,50 & 0,13 & 2,90 & 0,13 & 1,15 & 5,54 \\
\hline 4 & Durian & 6,67 & 1,50 & 0,20 & 4,35 & 0,14 & 1,26 & 7,10 \\
\hline 5 & Gamal & 68,33 & 15,36 & 0,40 & 8,70 & 1,72 & 15,61 & 39,66 \\
\hline
\end{tabular}




\begin{tabular}{|c|c|c|c|c|c|c|c|c|}
\hline No & Jenis & $\begin{array}{c}\mathrm{K} \\
\text { (Ind./ha) }\end{array}$ & $\begin{array}{l}\text { KR } \\
(\%) \\
\end{array}$ & $F$ & $\begin{array}{l}\text { FR } \\
(\%) \\
\end{array}$ & $\begin{array}{c}D \\
\left(m^{2} / h a\right) \\
\end{array}$ & $\begin{array}{l}\text { DR } \\
(\%) \\
\end{array}$ & $\begin{array}{l}\text { INP } \\
(\%) \\
\end{array}$ \\
\hline 6 & Gmelina & 11,67 & 2,62 & 0,13 & 2,90 & 1,05 & 9,49 & 15,01 \\
\hline 7 & Jambu & 1,67 & 0,37 & 0,07 & 1,45 & 0,02 & 0,14 & 1,96 \\
\hline 8 & Jati & 1,67 & 0,37 & 0,07 & 1,45 & 0,02 & 0,21 & 2,04 \\
\hline 9 & Jeruk Bali & 5,00 & 1,12 & 0,13 & 2,90 & 0,31 & 2,80 & 6,82 \\
\hline 10 & Karet & 1,67 & 0,37 & 0,07 & 1,45 & 0,04 & 0,36 & 2,19 \\
\hline 11 & Kelapa & 15,00 & 3,37 & 0,33 & 7,25 & 1,00 & 9,04 & 19,66 \\
\hline 12 & Kopi & 5,00 & 1,12 & 0,07 & 1,45 & 0,05 & 0,46 & 3,04 \\
\hline 13 & Lamtoro & 1,67 & 0,37 & 0,07 & 1,45 & 0,02 & 0,15 & 1,97 \\
\hline 14 & Langsat & 13,33 & 3,00 & 0,27 & 5,80 & 0,49 & 4,43 & 13,22 \\
\hline 15 & Mangga & 3,33 & 0,75 & 0,07 & 1,45 & 0,05 & 0,47 & 2,67 \\
\hline 16 & Mete & 3,33 & 0,75 & 0,13 & 2,90 & 0,10 & 0,95 & 4,60 \\
\hline 17 & Mojo & 3,33 & 0,75 & 0,13 & 2,90 & 0,05 & 0,41 & 4,06 \\
\hline 18 & Nangka & 3,33 & 0,75 & 0,13 & 2,90 & 0,22 & 1,98 & 5,63 \\
\hline 19 & Petai & 11,67 & 2,62 & 0,33 & 7,25 & 0,58 & 5,27 & 15,13 \\
\hline 20 & Rambutan & 6,67 & 1,50 & 0,27 & 5,80 & 0,08 & 0,70 & 8,00 \\
\hline 21 & Sengon & 10,00 & 2,25 & 0,27 & 5,80 & 0,71 & 6,42 & 14,47 \\
\hline 22 & Sp.3 & 1,67 & 0,37 & 0,07 & 1,45 & 0,46 & 4,16 & 5,98 \\
\hline \multirow[t]{2}{*}{23} & Sukun & 3,33 & 0,75 & 0,13 & 2,90 & 0,40 & 3,62 & 7,27 \\
\hline & Jumlah & 445,00 & 100,00 & 4,60 & 100,00 & 11,03 & 100,00 & 300,00 \\
\hline
\end{tabular}

Tabel 3.9 menunjukkan jenis tumbuhan yang dominan pada tingkat semai adalah kopi (INP 87,95 $\%$ ), sedangkan pada tingkat sapihan adalah karet (INP 79,15\%) dan coklat mendominasi pada tingkat pancang (INP 205,53 \%) dan pohon (INP 108,84). Adanya dominasi jenis kopi dan karet pada agoforestri coklat menunjukkan adanya introduksi jenis baru pada sistem tersebut yang berlangsung belum lama atau telah terjadi pemilihan jenis baru dalam sistem coklat sebagai alternatif pengganti komoditi jika harga coklat mengalami penurunan. Disamping itu kopi tergolong jenis yang membutuhkan naungan seperti coklat.

Jenis pohon yang dominan menjadi penaung coklat adalah Gamal (Gliricidia maculate). Gamal tergolong jenis MPTS cepat tumbuhan dan berperan pula sebagai pakan ternak. Selain itu menurut Schwendenmann et al (2010), kehadiran gamal dalam sistem agroforestry coklat membantu pertumbuhan coklat ketika memasuki musim kering khususnya dalam menyediakan iklim mikro yang kondusif bagi pertumbuhan coklat.

Secara umum tingkat dominasi jenis pohon buah-buahan sangat besar pada pola agroforestry coklat $(65,2 \%)$ baik ditanam pada posisi sebagai tanaman pagar maupun tanaman sela. Hal ini menunjukkan sebuah pola agroforestry komplek yang mewakili kebutuhan masyarakat akan pangan, pakan ternak dan kayu pertukangan. Jenis sukun, rambutan, nangka, jambu, durian dan lamtoro merupakan tanaman pangan, sedangkan gamal merupakan pakan ternak. Sementara itu coklat mengakomodasi kebutuhan uang kontan ekonomi rumah tangga; gmelina serta sengon mengakomodasi kebutuhan 
kayu pertukangan. Agroforestry coklat dapat menjadi contoh consensus antara kebutuhan ekonomi dan biodiversitas.

\section{Agroforestry Cengkeh}

Cengkeh merupakan jenis tanaman perkebunan yang banyak dikembangkan di sekitar wilayah tengah dan hulu DAS Balangtieng meskipun secara umum tidak tergolong komoditi utama perkebunan di Kabupaten Bulukumba. Menurut Martini et al (2014), agroforestry cengkeh banyak dijumpai di Provinsi Sulawesi Selatan dengan kombinasi pola Cengkeh dengan jagung, buah-buahan, kopi, coklat, bawang merah dan lada. Adapun pola agroforestry cengkeh di sekitarDAS Balangtieng dalam bentuk kombinasi dengan tanaman HHBK buah-buahan dan lada dengan gamal sebagai perambat sebagaimana Tabel 3.10.

Tabel 3.10 Kerapatan populasi jenis tumbumbuhan berdasarkan tingkat pertumbuhan pada agroforestry Cengkeh di sekitar DAS Balangtieng Kabupaten Bulukumba

\begin{tabular}{|c|c|c|c|c|c|c|c|}
\hline \multirow{2}{*}{ No } & \multirow{2}{*}{ Nama Lokal } & \multirow{2}{*}{ Nama Latin } & \multicolumn{4}{|c|}{ Kerapatan populasi (individu/ha) } & \multirow{2}{*}{ Kategori } \\
\hline & & & Semai & Sapihan & Pancang & Pohon & \\
\hline 1 & Cengkeh & Syzygium aromaticum & - & 106,67 & 126,67 & 298,33 & $\mathrm{PC}$ \\
\hline 2 & Coklat & Theobroma cacao & - & - & 13,33 & 1,67 & $\mathrm{PC}$ \\
\hline 3 & Dadap & Erytrina variegata & - & - & 6,67 & 1,67 & $\mathrm{KA}$ \\
\hline 4 & Durian & Durio zibhetinus & - & 26,67 & 13,33 & 11,67 & $\mathrm{HB}$ \\
\hline 5 & Gamal & Gliricidia maculata & - & 53,33 & 233,33 & 43,33 & MPTS \\
\hline 6 & Gmelina & Gmelina arborea & - & - & - & 1,67 & $\mathrm{~K}$ \\
\hline 7 & Kayu Cina & Lannea coromandelica & - & - & 13,33 & 5,00 & MPTS \\
\hline 8 & Kopi & Coffea sp. & 333,33 & 106,67 & 33,33 & 1,67 & $\mathrm{PC}$ \\
\hline 9 & Lada & Piper nigrum & 833,33 & - & - & - & PC \\
\hline 10 & Langsat & Lansium domesticum & - & - & 20,00 & 5,00 & $\mathrm{HB}$ \\
\hline 11 & Mojo & Crescentia cujete & - & - & - & 1,67 & $\mathrm{HB}$ \\
\hline 12 & Nangka & $\begin{array}{l}\text { Artocarpus } \\
\text { heterophyllus }\end{array}$ & - & - & - & 6,67 & $\mathrm{HB}$ \\
\hline 13 & Petai & Parkia speciosa & - & - & - & 6,67 & $\mathrm{HB}$ \\
\hline 14 & Pulai & Alstonia scholaris & - & - & - & 1,67 & $\mathrm{~K}$ \\
\hline 15 & Randu & Ceiba pentandra & - & 26,67 & - & - & $\mathrm{K}$ \\
\hline 16 & Suren & Toona sureni & - & - & 6,67 & 11,67 & $\mathrm{~K}$ \\
\hline
\end{tabular}

Tabel 3.10 dan 3.11 menunjukkan komposisi jenis penyusun agroforestry cengkeh terdiri atas 16 jenis tumbuhan dengan sebaran tingkat pertumbuhan meliputi 2 jenis tergolong semai, 5 jenis sapihan, 9 jenis pancang dan 14 jenis pohon. Beberapa jenis tumbuhan yang tergolong perennial crop dijumpai dikombinasikan dengan cengkeh meskipun kerapatannya rendah dan didominasi oleh lada dan kopi (Gambar 3.5). Namun sebagian besar masyarakat menanam cengkeh dengan pola monokultur terutama ketika cengkeh telah tergolong pancang karena anggapan kehadiran jenis lainnya dapat 
mengganggu produktivitas cengkeh. Disamping itu jenis lain banyak ditanam sebagai tanaman pagar atau pembatas lahan seperti jenis buah-buahan.

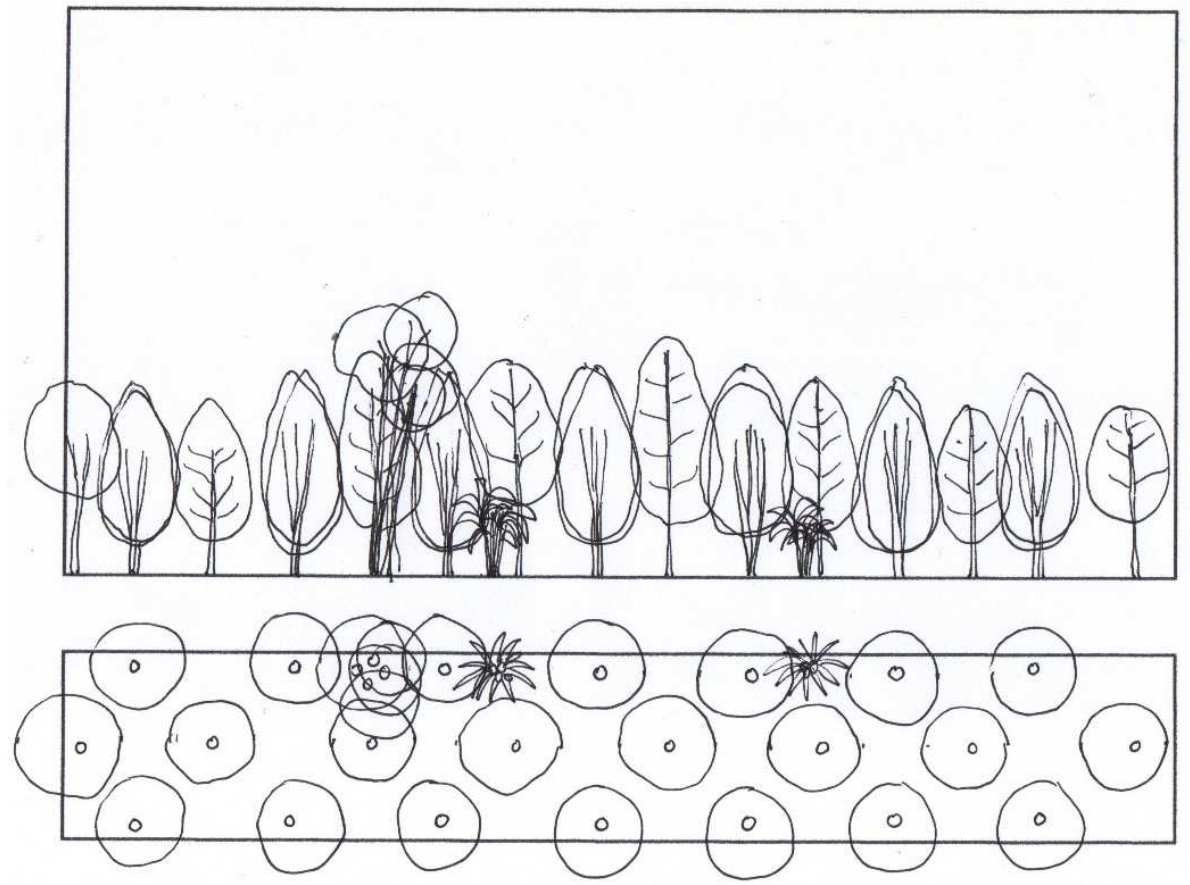

Gambar 3.5 Diagram profil tegakan pada sistem agroforestry cengkeh

Tabel 3.11 menunjukkan struktur vegetasi agroforestry cengkeh dengan komposisi jenis dan kerapatan yang semakin meningkat seiring dengan meningkatnya tingkat pertumbuhan. Kondisi tersebut menunjukkan struktur vegetasi yang tidak sehat secara alami khususnya dalam menjamin proses regenerasi secara alami. Hal ini menunjukkan tingkat pengelolaan agroforestry cengkeh cukup intensif.

Tabel 3.11 Struktur Vegetasi Agroforestry Cengkeh di sekitar DAS Balangtieng Kabupaten Bulukumba

\begin{tabular}{|c|c|c|c|c|c|c|c|c|}
\hline No & Jenis & $\begin{array}{c}\mathrm{K} \\
\text { (Ind/ha) } \\
\end{array}$ & $\begin{array}{l}\mathrm{KR} \\
(\%) \\
\end{array}$ & $F$ & $\begin{array}{l}\text { FR } \\
(\%)\end{array}$ & $\begin{array}{c}\mathrm{D} \\
\left(\mathrm{m}^{2} / \mathrm{ha}\right)\end{array}$ & $\begin{array}{l}\mathrm{DR} \\
(\%) \\
\end{array}$ & $\begin{array}{l}\text { INP } \\
(\%)\end{array}$ \\
\hline \multicolumn{9}{|l|}{ Semai } \\
\hline 1 & Lada & 833,33 & 71,43 & 0,33 & 83,33 & - & - & 154,76 \\
\hline 2 & Kopi & 333,33 & 28,57 & 0,07 & 16,67 & - & - & 45,24 \\
\hline & Jumlah & 1166,67 & 100,00 & 0,40 & 100,00 & - & - & 200,00 \\
\hline \multicolumn{9}{|l|}{ Sapihan } \\
\hline 1 & Cengkeh & 106,67 & 33,33 & 0,27 & 36,36 & - & - & 69,70 \\
\hline 2 & Kopi & 106,67 & 33,33 & 0,27 & 36,36 & - & - & 69,70 \\
\hline 3 & Randu & 26,67 & 8,33 & 0,07 & 9,09 & - & - & 17,42 \\
\hline 4 & Gamal & 53,33 & 16,67 & 0,07 & 9,09 & - & - & 25,76 \\
\hline 5 & Durian & 26,67 & 8,33 & 0,07 & 9,09 & - & - & 17,42 \\
\hline & Jumlah & 320 & 100 & 0,73 & 100,00 & - & - & 200,00 \\
\hline \multicolumn{9}{|l|}{ Pancang } \\
\hline 1 & Cengkeh & 126,67 & 27,14 & 0,40 & 24,00 & 0,70 & 34,57 & 85,72 \\
\hline 2 & Coklat & 13,33 & 2,86 & 0,13 & 8,00 & 0,04 & 1,88 & 12,74 \\
\hline
\end{tabular}




\begin{tabular}{|c|c|c|c|c|c|c|c|c|}
\hline No & Jenis & $\begin{array}{c}\mathrm{K} \\
\text { (Ind/ha) }\end{array}$ & $\begin{array}{l}\text { KR } \\
(\%)\end{array}$ & $F$ & $\begin{array}{l}\text { FR } \\
(\%)\end{array}$ & $\begin{array}{c}D \\
\left(m^{2} / h a\right)\end{array}$ & $\begin{array}{l}\text { DR } \\
(\%)\end{array}$ & $\begin{array}{l}\text { INP } \\
(\%)\end{array}$ \\
\hline 3 & Dadap & 6,67 & 1,43 & 0,07 & 4,00 & 0,03 & 1,63 & 7,06 \\
\hline 4 & Durian & 13,33 & 2,86 & 0,13 & 8,00 & 0,06 & 3,19 & 14,04 \\
\hline 5 & Gamal & 233,33 & 50,00 & 0,33 & 20,00 & 0,98 & 48,16 & 118,16 \\
\hline 6 & Kayu Cina & 13,33 & 2,86 & 0,13 & 8,00 & 0,03 & 1,42 & 12,28 \\
\hline 7 & Kopi & 33,33 & 7,14 & 0,20 & 12,00 & 0,11 & 5,23 & 24,37 \\
\hline 8 & Langsat & 20,00 & 4,29 & 0,20 & 12,00 & 0,06 & 2,98 & 19,27 \\
\hline 9 & Suren & 6,67 & 1,43 & 0,07 & 4,00 & 0,02 & 0,94 & 6,37 \\
\hline & Jumlah & 466,67 & 100,00 & 1,67 & 100,00 & 2,04 & 100,00 & 300,00 \\
\hline \multicolumn{9}{|l|}{ Pohon } \\
\hline 1 & Cengkeh & 298,33 & 74,90 & 1,00 & 34,88 & 6,31 & 74,82 & 184,60 \\
\hline 2 & Coklat & 1,67 & 0,42 & 0,07 & 2,33 & 0,01 & 0,17 & 2,92 \\
\hline 3 & Dadap & 1,67 & 0,42 & 0,07 & 2,33 & 0,02 & 0,19 & 2,94 \\
\hline 4 & Durian & 11,67 & 2,93 & 0,33 & 11,63 & 0,46 & 5,45 & 20,01 \\
\hline 5 & Kayu Cina & 5,00 & 1,26 & 0,13 & 4,65 & 0,05 & 0,55 & 6,45 \\
\hline 6 & Kopi & 1,67 & 0,42 & 0,07 & 2,33 & 0,08 & 0,93 & 3,68 \\
\hline 7 & Langsat & 5,00 & 1,26 & 0,20 & 6,98 & 0,21 & 2,48 & 10,72 \\
\hline 8 & Nangka & 6,67 & 1,67 & 0,13 & 4,65 & 0,23 & 2,71 & 9,03 \\
\hline 9 & Petai & 6,67 & 1,67 & 0,20 & 6,98 & 0,16 & 1,94 & 10,59 \\
\hline 10 & Pulai & 1,67 & 0,42 & 0,07 & 2,33 & 0,02 & 0,19 & 2,94 \\
\hline 11 & Suren & 11,67 & 2,93 & 0,13 & 4,65 & 0,36 & 4,23 & 11,81 \\
\hline 12 & Gamal & 43,33 & 10,88 & 0,33 & 11,63 & 0,50 & 5,88 & 28,39 \\
\hline 13 & Gmelina & 1,67 & 0,42 & 0,07 & 2,33 & 0,02 & 0,19 & 2,94 \\
\hline 14 & Mojo & 1,67 & 0,42 & 0,07 & 2,33 & 0,02 & 0,25 & 3,00 \\
\hline & Jumlah & 398,33 & 100,00 & 2,87 & 100,00 & 8,43 & 100,00 & 300,00 \\
\hline
\end{tabular}

Keterangan: K = Kerapatan; KR = Kerapatan Relatif; F = Frekuensi; FR = Frekuensi Relatif; D = Dominansi; DR = Dominansi Relatif; INP = Indek Nilai Penting

Struktur vegetasi pada tingkat semai hanya tersusun atas 2 jenis tumbuhan dan didominasi oleh lada sebagai tanaman bawah yang merambat pada pohon gamal dengan INP 154,76. Rendahnya jumlah semai pada pola agroforestry cengkeh menunjukkan tingkat pengelolaan SPL ini cukup intensif terutama dalam pemeliharaan dan pemanenan buah sehingga proses regenerasi alami tidak berjalan normal.

Sementara itu struktur vegetasi pada tingkat sapihan lebih banyak dibandingkan semai dengan ditemukannya beberapa jenis tanaman MPTs seperti gamal serta didominasi jenis cengkeh (INP 69,7) dan kopi (INP 69,7). Kehadiran cengkeh pada tingkat sapihan karena introduksi tanaman baru atau sengaja ditanam bukan hasil regenerasi alami.

Pada tingkat pancang dijumpai jumlah jenis tumbuhan lebih banyak dibandingkan sapihan dan semai dengan dominasi jenis gamal (INP 118,16) dan cengkeh (INP 85,72). Kehadiran gamal pada pola agroforestry cengkeh berperan sebagai tanaman perambat bagi lada dan sebagai tanaman pembatas lahan. Demikian pula kehadiran kayu cina biasanya digunakan sebagai tanaman pagar oleh masyarakat karena tergolong tanaman cepat tumbuh (Gambar 3.6). 

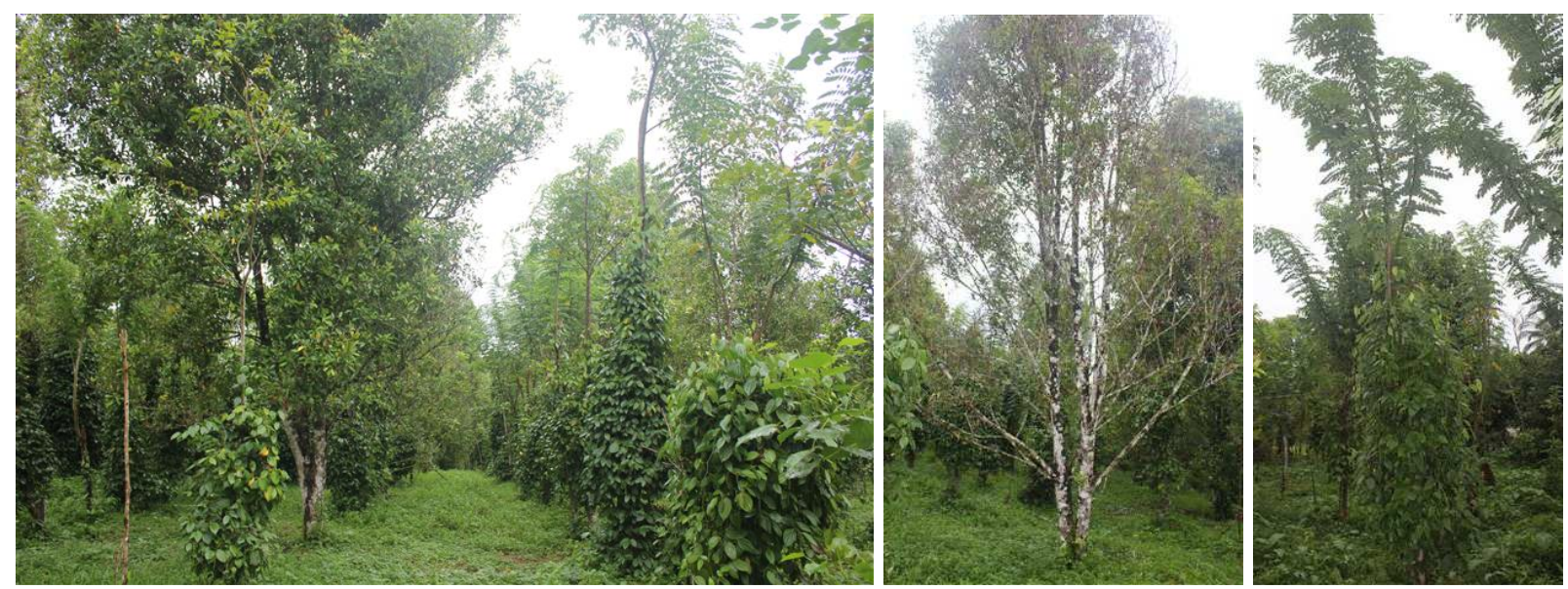

Gambar 3.6 Agroforestry cengkeh yang dikombinasikan dengan lada dengan tanaman gamal sebagai tiang perambat

Pada tingkat pohon mengalami peningkatan jenis tumbuhan terutama jenis-jenis tanaman MPTs dan HHBK yang keberadaanya lebih banyak sebagai tanaman pagar dan buah-buahan. Jenis pohon didominasi oleh cengkeh dengan dominasi yang cukup tinggi (INP 184,6) terutama disebabkan oleh tingkat kerapatan tumbuhan yang mencapai 298,33 individu/ha.

\section{Agroforestry Kopi}

Kopi banyak dikembangkan oleh masyarakat sekitar DAS Balangtieng wilayah hulu dengan pola agroforestry komplek. Komposisi jenis tumbuhan yang dijumpai pada pola agroforestry kopi sebanyak 17 jenis tumbuhan pepohonan meliputi 4 jenis tergolong semai, 6 jenis tergolong sapihan, 7 jenis tergolong pancang dan 13 jenis tergolong pohon. Sebagian jenis tumbuhan tergolong tanaman penghasil kayu pertukangan baik hasil budidaya maupun kayu hutan alam sebagaimana Tabel 3.12. Kondisi tersebut menunjukkan adanya perbedaan pemilihan jenis pohon dengan pola agroforestry kelapa, jambu mete, coklat dan cengkeh dimana jenis pohon yang menjadi penyusun sebagian besar tergolong buah-buahan bukan tanaman penghasil kayu. Kondisi tersebut kemungkinan disebabkan oleh peran tanaman penghasil kayu yang lebih cocok sebagai penaung tanaman coklat (Gambar 3.7). Disamping itu pertimbangan lainnya adalah kesesuaian habitat jenis tumbuhan MPTS untuk daerah dataran tinggi dan kebutuhan akan kayu pertukangan yang sulit diakses dari pasar atau pedagang kayu sehingga kayu-kayuan lebih ekonomis.

Tabel 3.12 Kerapatan populasi jenis tumbuhan berdasarkan tingkat pertumbuhan pada agroforestry Kopi di sekitar DAS Balangtieng Kabupaten Bulukumba

\begin{tabular}{lllccccc}
\hline \multirow{2}{*}{ No } & \multirow{2}{*}{ Nama Lokal } & Nama Latin & \multicolumn{3}{c}{ Kerapatan populai (individu/ha) } \\
\cline { 5 - 7 } & & Semai & Sapihan & Pancang & Pohon \\
\hline 1 & Kayu afrika & Maesopsis eminii & - & 40 & - & 2,5 & K \\
\hline 2 & Aren & Arenga pinnata & 250 & 160 & - & 2,5 & HP \\
3 & Bakam Kampung & Litsea elliptica & - & - & - & 7,5 & KA \\
4 & Biti & Vitex cofassu & - & - & 10 & - & KA \\
\hline
\end{tabular}




\begin{tabular}{|c|c|c|c|c|c|c|c|}
\hline \multirow{2}{*}{ No } & \multirow{2}{*}{ Nama Lokal } & \multirow{2}{*}{ Nama Latin } & \multicolumn{4}{|c|}{ Kerapatan populai (individu/ha) } & \multirow{2}{*}{ Kategori } \\
\hline & & & Semai & Sapihan & Pancang & Pohon & \\
\hline 5 & Cengkeh & Syzygium aromaticum & 10 & - & - & - & $\mathrm{PC}$ \\
\hline 6 & Coklat & Theobroma cacao & - & 40 & 10 & 5 & $\mathrm{PC}$ \\
\hline 7 & Dadap & Erytrina variegata & - & - & - & 12,5 & $\mathrm{KA}$ \\
\hline 8 & Donri & Ficus sp. & - & - & - & 5 & $\mathrm{KA}$ \\
\hline 9 & Jenitri & Elaeocarpus sp. & - & - & - & 2,5 & $\mathrm{KA}$ \\
\hline 10 & Jambu Klutuk & Psidium guajava & - & 40 & - & - & $\mathrm{HB}$ \\
\hline 11 & Kayu Manis & Cinnamomum burmanii & - & - & - & 2,5 & $\mathrm{HM}$ \\
\hline 12 & Kisereh & $\begin{array}{l}\text { Cinnamomum } \\
\text { parthenoxylon }\end{array}$ & - & - & 30 & - & $\mathrm{HM}$ \\
\hline 13 & Kopi & Coffea $s p$ & 6750 & 4440 & 220 & 5 & $\mathrm{PC}$ \\
\hline 14 & Langsat & Lansium domesticum & 2250 & - & 30 & 30 & $\mathrm{HB}$ \\
\hline 15 & Pipturus & Pipturus sp. & - & - & - & 5 & $\mathrm{KA}$ \\
\hline 16 & Sengon & Falcataria moluccana & - & - & 30 & 25 & $\mathrm{~K}$ \\
\hline 17 & Suren & Toona sureni & - & 80 & 60 & 15 & K \\
\hline
\end{tabular}

Struktur vegetasi agroforestry kopi secara umum tergolong tidak normal yang ditunjukkan dengan sebaran jenis pada setiap tingkat pertumbuhan yang tidak merata kecuali jenis kopi . Hal menarik lainnya adalah jenis biti masih dijumpai pada pola agroforestry kopi meskipun tergolong dataran tinggi meskipun masih tergolong pancang dengan kerapatan 10 individu/ha. Kehadiran jenis biti kemungkinan karena adanya program pemerintah dalam konservasi jenis melalui pengayaan jenis biti di lahan masyarakat.

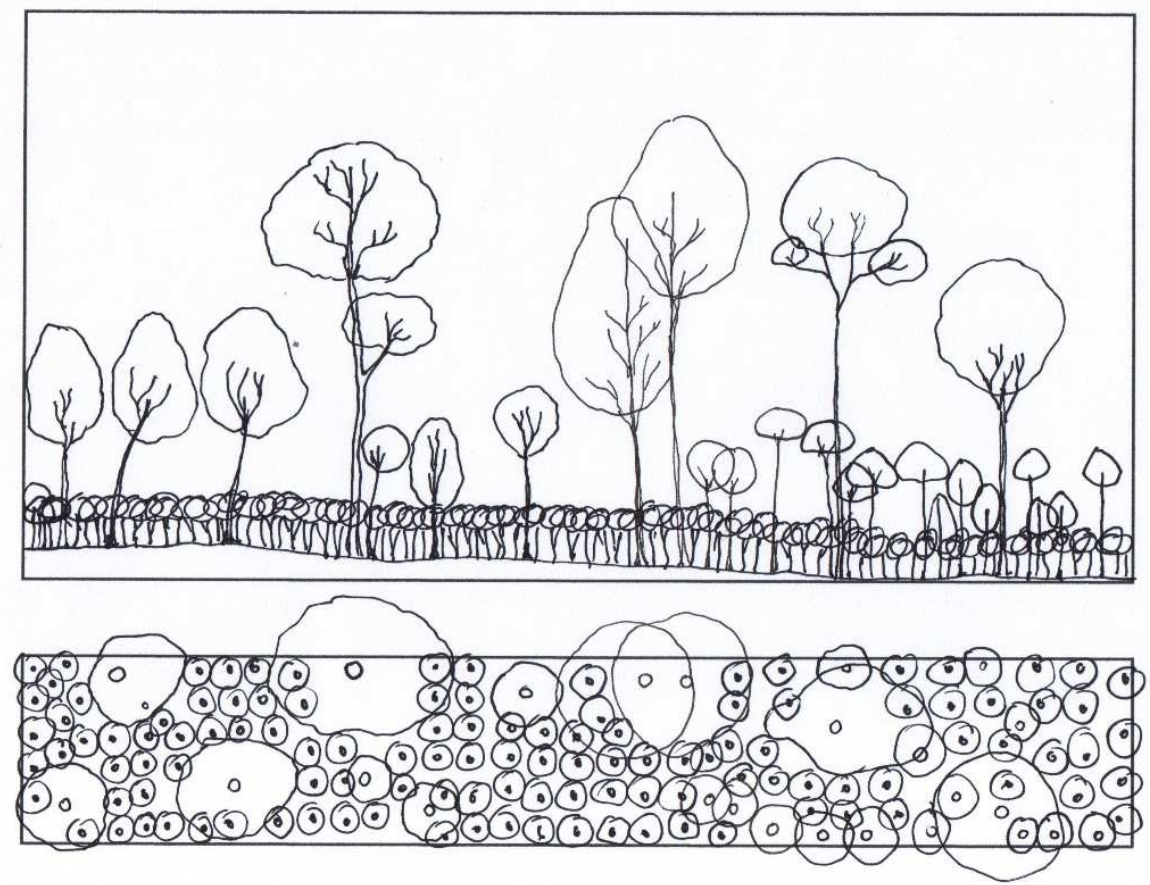

Gambar 3.7 Diagram profil tegakan pada sistem agroforestry kopi 
Tabel 3.13 Struktur Vegetasi Agroforestry Kopi di sekitar DAS Balangtieng Kabupaten Bulukumba

\begin{tabular}{|c|c|c|c|c|c|c|c|c|}
\hline No & Jenis & $\begin{array}{c}\mathrm{K} \\
\text { (Ind./Ha) } \\
\end{array}$ & $\begin{array}{l}\text { KR } \\
(\%) \\
\end{array}$ & $F$ & $\begin{array}{l}\mathrm{FR} \\
(\%) \\
\end{array}$ & $\begin{array}{c}\mathrm{D} \\
\left(\mathrm{m}^{2} / \mathrm{Ha}\right)\end{array}$ & $\begin{array}{l}\text { DR } \\
(\%)\end{array}$ & $\begin{array}{l}\text { INP } \\
(\%)\end{array}$ \\
\hline \multicolumn{9}{|c|}{ Semai } \\
\hline 1 & Aren & 250 & 2,63 & 0,1 & 11,11 & - & - & 13,74 \\
\hline 2 & Cengkeh & 250 & 2,63 & 0,1 & 11,11 & - & - & 13,74 \\
\hline 3 & Kopi & 6750 & 71,05 & 0,5 & 55,56 & - & - & 126,61 \\
\hline \multirow[t]{2}{*}{4} & Langsat & 2250 & 23,68 & 0,2 & 22,22 & - & - & 45,91 \\
\hline & Jumlah & 9500 & 100 & 0,9 & 100,00 & - & - & 200,00 \\
\hline \multicolumn{2}{|c|}{ Sapihan } & & & & & - & - & \\
\hline 1 & Kayu afrika & 40 & 0,83 & 0,1 & 7,14 & - & - & 7,98 \\
\hline 2 & Aren & 160 & 3,33 & 0,1 & 7,14 & - & - & 10,48 \\
\hline 3 & Coklat & 40 & 0,83 & 0,1 & 7,14 & - & - & 7,98 \\
\hline 4 & Jambu klutuk & 40 & 0,83 & 0,1 & 7,14 & - & - & 7,98 \\
\hline 5 & Kopi & 4440 & 92,50 & 0,9 & 64,29 & - & - & 156,79 \\
\hline \multirow[t]{2}{*}{6} & Suren & 80 & 1,67 & 0,1 & 7,14 & - & - & 8,81 \\
\hline & Jumlah & 4800 & 100 & 1,4 & 100 & - & - & 200 \\
\hline \multicolumn{9}{|c|}{ Pancang } \\
\hline 1 & Biti & 10 & 2,56 & 0,10 & 5,26 & 0,07 & 5,62 & 13,44 \\
\hline 2 & Coklat & 10 & 2,56 & 0,10 & 5,26 & 0,03 & 2,16 & 9,99 \\
\hline 3 & Kisereh & 30 & 7,69 & 0,10 & 5,26 & 0,13 & 11,24 & 24,20 \\
\hline 4 & Kopi & 220 & 56,41 & 0,80 & 42,11 & 0,56 & 47,39 & 145,91 \\
\hline 5 & Langsat & 30 & 7,69 & 0,20 & 10,53 & 0,12 & 9,89 & 28,11 \\
\hline 6 & Sengon & 30 & 7,69 & 0,30 & 15,79 & 0,12 & 9,91 & 33,39 \\
\hline \multirow[t]{2}{*}{7} & Suren & 60 & 15,38 & 0,30 & 15,79 & 0,16 & 13,78 & 44,95 \\
\hline & Jumlah & 390 & 100,00 & 1,90 & 100,00 & 1,19 & 100,00 & 300,00 \\
\hline \multicolumn{9}{|c|}{ Pohon } \\
\hline 1 & Kayu afrika & 2,5 & 2,08 & 0,10 & 3,23 & 0,03 & 0,45 & 5,76 \\
\hline 2 & Aren & 2,5 & 2,08 & 0,10 & 3,23 & 0,08 & 1,40 & 6,71 \\
\hline 3 & $\begin{array}{l}\text { Bakam } \\
\text { kampung }\end{array}$ & 7,5 & 6,25 & 0,30 & 9,68 & 0,36 & 5,93 & 21,86 \\
\hline 4 & Coklat & 5 & 4,17 & 0,10 & 3,23 & 0,05 & 0,91 & 8,30 \\
\hline 5 & Dadap & 12,5 & 10,42 & 0,40 & 12,90 & 0,97 & 16,05 & 39,37 \\
\hline 6 & Donri & 5 & 4,17 & 0,10 & 3,23 & 0,33 & 5,48 & 12,87 \\
\hline 7 & Ganitri & 2,5 & 2,08 & 0,10 & 3,23 & 0,30 & 4,92 & 10,23 \\
\hline 8 & Kayu manis & 2,5 & 2,08 & 0,10 & 3,23 & 0,03 & 0,53 & 5,84 \\
\hline 9 & Kopi & 5 & 4,17 & 0,20 & 6,45 & 0,22 & 3,59 & 14,21 \\
\hline 10 & Langsat & 30 & 25,00 & 0,70 & 22,58 & 1,43 & 23,82 & 71,40 \\
\hline 11 & Pipturus sp. & 5 & 4,17 & 0,10 & 3,23 & 0,09 & 1,42 & 8,81 \\
\hline 12 & Sengon & 25 & 20,83 & 0,70 & 22,58 & 1,97 & 32,73 & 76,14 \\
\hline \multirow[t]{2}{*}{13} & Suren & 15 & 12,50 & 0,10 & 3,23 & 0,17 & 2,78 & 18,51 \\
\hline & Jumlah & 120 & 100,00 & 3,10 & 100,00 & 6,02 & 100,00 & 300,00 \\
\hline
\end{tabular}

Keterangan: $\mathrm{K}=$ Kerapatan; $\mathrm{KR}=$ Kerapatan Relatif; $\mathrm{F}=$ Frekuensi; $\mathrm{FR}=$ Frekuensi Relatif; $\mathrm{D}=$ Dominansi; DR = Dominansi Relatif; INP = Indek Nilai Penting

Tabel 3.13 menunjukkan jenis tumbuhan yang mendominasi pada setiap tingkat pertumbuhan adalah kopi dengan nilai INP semai 126,61 \%, sapihan 156,79\%, dan pancang 145,91\%. Kondisi tersebut 
menunjukkan bahwa agroforestry kopi telah menjamin proses regenerasi alami kopi. Disamping itu pada beberapa tingkat pertumbuhan masih dijumpai beberapa jenis pohon asli hutan alam setempat seperti donri, biti, ganitri dan bakam kampung. Hal ini menunjukkan bahwa pola agroforestry kopi yang dikembangkan oleh masyarakat di sekitar DAS Balangtieng masih mengakomodasi kepentingan konservasi jenis pada lahan milik yang menjadi zona penyangga hutan lindung setempat. Selain jenis kayu lokal ditemukan pula jenis kayu nasional yang ditanam sebagai pengaruh dari gerakan penghijauan sengon di hutan sekunder sebelumnya yaitu sengon dengan nilai INP 76,14 dan kerapatan yang cukup besar yaitu 25 individu/ha.

\section{Agroforestry Kebun Campuran}

Kebun campuran merupakan salah satu penciri hutan rakyat di berbagai daerah di Indonesia dengan komposisi vegetasi pohon yang cukup beragam, sehingga kebun campuran menjadi spot andalan biodiversitas pada pola agroforestry selama ini. Komposisi jenis penyusun kebun campuran di sekitar DAS Balangtieng dari hulu hingga hilir terdiri atas 48 jenis pohon meliputi 24 jenis semai, 12 jenis sapihan, 15 jenis pancang, 35 jenis pohon. Sebagian besar (42,8\%) tumbuhan penyusun kebun campuran tergolong tanaman HHBK buah-buahan dan tumbuhan penghasil kayu pertukangan (38,7\%). Jumlah jenis tumbuhan kebun campuran di sekitar DAS Balangtieng lebih banyak dibandingkan dengan kebun campuran di wilayah Gowa Sulawesi Selatan yang mencapai 28 jenis (Millang 2015) dan Pandeglang dan Sukabumi Jawa Barat yang hanya mencapai 39 jenis (Widiarti and Prajadinata 2008).

Tabel 3.14 Kerapatan populasi jenis tumbuhan berdasarkan tingkat pertumbuhan pada agroforestry Kebun Campuran di sekitar DAS Balangtieng Kabupaten Bulukumba

\begin{tabular}{|c|c|c|c|c|c|c|c|}
\hline \multirow{2}{*}{ No } & \multirow{2}{*}{ Nama Lokal } & \multirow{2}{*}{ Nama Latin } & \multicolumn{4}{|c|}{ Kerapatan populasi (individu/ha) } & \multirow{2}{*}{ Kategori } \\
\hline & & & Semai & Sapihan & Pancang & Pohon & \\
\hline 1 & Angsana & Pterocarpus indicus & - & - & - & 1,25 & $\mathrm{KA}$ \\
\hline 2 & Aren & Arengan pinnata & 3000,00 & - & - & 5,00 & $\mathrm{HP}$ \\
\hline 3 & Bakang Kampung & Litsea elliptica & - & 40 & 5 & - & KA \\
\hline 4 & Biti & Vitex cofassus & 125,00 & - & 5 & 18,75 & KA \\
\hline 5 & Cengkeh & Syzygium aromaticum & 250,00 & 20 & 25 & 42,50 & $\mathrm{PC}$ \\
\hline 6 & Cokelat & Theobroma cacao & 1125,00 & 60 & 115 & 63,75 & $\mathrm{PC}$ \\
\hline 7 & Dadap & Erytrina variegata & - & - & 15 & - & KA \\
\hline 8 & Durian & Durio zibhetinus & - & - & - & 5,00 & $\mathrm{HB}$ \\
\hline 9 & Ficus & Ficus septica & - & - & - & 1,25 & KA \\
\hline 10 & Galumpang & - & - & - & - & 2,50 & $\mathrm{KA}$ \\
\hline 11 & Gamal & Gliricidia maculata & 375,00 & 80 & 20 & - & MPTS \\
\hline 12 & Gmelina & Gmelina arborea & 125,00 & 20 & - & 45,00 & K \\
\hline 13 & Homalantus & Homalanthus sp. & - & - & - & 2,50 & $\mathrm{KA}$ \\
\hline 14 & Jambu Air & Eugenia aquea & 250,00 & - & - & - & $\mathrm{HB}$ \\
\hline 15 & Jambu Bol & Syzygium malaccense & - & - & - & 1,25 & $\mathrm{HB}$ \\
\hline 16 & Jarak & Jatropa curcas & 500,00 & - & - & - & HM \\
\hline
\end{tabular}




\begin{tabular}{|c|c|c|c|c|c|c|c|}
\hline \multirow{2}{*}{ No } & \multirow{2}{*}{ Nama Lokal } & \multirow{2}{*}{ Nama Latin } & \multicolumn{4}{|c|}{ Kerapatan populasi (individu/ha) } & \multirow{2}{*}{ Kategor } \\
\hline & & & Semai & Sapihan & Pancang & Pohon & \\
\hline 17 & Jejerukan & Citrus sp. & 125,00 & - & - & - & $\mathrm{KA}$ \\
\hline 18 & Jengkol & Archidendron pauciflorum & 125,00 & 40 & 5 & - & $\mathrm{HB}$ \\
\hline 19 & Jeruk & Citrus sp. & - & - & - & 1,25 & $\mathrm{HB}$ \\
\hline 20 & Kadieng & Citrus sp. & 750,00 & 20 & - & 5,00 & $\mathrm{~K}$ \\
\hline 21 & Kayu Cina & Lannea coromandelica & - & - & - & 1,25 & MPTS \\
\hline 22 & Kedondong & Spondias dulcis & - & - & - & 77,50 & $\mathrm{HB}$ \\
\hline 23 & Kelapa & Cocos nucifera & 125,00 & - & 5 & 5,00 & $\mathrm{HP}$ \\
\hline 24 & Kemiri & Aleuritas moluccana & 625,00 & - & - & 1,25 & $\mathrm{HB}$ \\
\hline 25 & Kenanga & Cananga odorata & - & - & - & 1,25 & $\mathrm{KA}$ \\
\hline 26 & Kepuh & Sterculia foetida & - & - & - & 1,25 & $\mathrm{KA}$ \\
\hline 27 & Ketapang & Terminalia catapa & 5000,00 & 20 & - & - & $\mathrm{KA}$ \\
\hline 28 & Kisereh & $\begin{array}{l}\text { Cinnamomum } \\
\text { parthenoxylon }\end{array}$ & - & - & - & 1,25 & $\mathrm{HM}$ \\
\hline 29 & Kopi & Coffea sp. & 3125,00 & 160 & 5 & 40,00 & PC \\
\hline 30 & Langsat & Lansium domesticum & 375,00 & 20 & 10 & 11,25 & $\mathrm{HB}$ \\
\hline 31 & Makaranga & Macaranga tanarius & 125,00 & - & - & - & $\mathrm{KA}$ \\
\hline 32 & Mangga & Mangifera indica & 625,00 & - & - & 1,25 & $\mathrm{HB}$ \\
\hline 33 & Manggis & Garcinia mangostana & - & - & 5 & - & $\mathrm{HB}$ \\
\hline 34 & Matoa & Pometia pinnata & - & - & & 3,75 & $\mathrm{HB}$ \\
\hline 35 & Mete & Anacardium occidentale & - & - & 10 & 30,00 & $\mathrm{HB}$ \\
\hline 36 & Nanas & Ananas commusus & 125,00 & - & - & - & $A C$ \\
\hline 37 & Nangka & $\begin{array}{l}\text { Artocarpus } \\
\text { heterophyllus }\end{array}$ & 125,00 & - & - & - & $\mathrm{HB}$ \\
\hline 38 & Petai & Parkia speciosa & 125,00 & - & - & 1,25 & $\mathrm{HB}$ \\
\hline 39 & Pinang & Areca catechu & 250,00 & - & - & - & $\mathrm{HB}$ \\
\hline 40 & Rambutan & Nephelium lapacheum & 4250,00 & 40 & 5 & 1,25 & $\mathrm{HB}$ \\
\hline 41 & Rao & $\begin{array}{l}\text { Dracontomelon } \\
\text { mangiferum }\end{array}$ & - & - & - & 1,25 & $\mathrm{KA}$ \\
\hline 42 & Sengon & Falcataria moluccana & - & - & - & 1,25 & $\mathrm{~K}$ \\
\hline 43 & Sentul & Sandoricum koetjape & - & - & - & 2,50 & $\mathrm{KA}$ \\
\hline 44 & Sirsak & Annona muricata & 250,00 & - & 5 & - & $\mathrm{HB}$ \\
\hline 45 & Sp.1 & & - & - & - & 1,25 & $\mathrm{KA}$ \\
\hline 46 & Sp.6 & & - & - & - & 2,50 & $\mathrm{KA}$ \\
\hline 47 & Spatodea & $\begin{array}{l}\text { Spathodea } \\
\text { campanulata }\end{array}$ & - & - & - & 8,75 & MPTS \\
\hline 48 & Suren & Toona sureni & - & 40 & 5 & 1,25 & $\mathrm{~K}$ \\
\hline 49 & Waru & Hibiscus tiliaceus & - & - & - & 1,25 & $\mathrm{KA}$ \\
\hline
\end{tabular}

Keterangan: HB = HHBK Buah; HP = HHBK Pati; HM = HHBK Minyak; HG = HHBK Getah; MPTS = Multipurpose Tree Species; K = Kayu Pertukangan; KA = Kayu Alam; PC = Perenial Crop

Tabel 3.14 menunjukkan bahwa struktur vegetasi kebun campuran tidak normal yang ditunjukkan oleh sebagian besar tumbuhan tidak tersebar pada berbagai tingkat pertumbuhan. Meskipun demikian sebagian besar tumbuhan yang tergolong HHBK dan perrenial crop memiliki struktur cukup baik seperti rambutan, langsat, cengkeh, kopi dan coklat. 
Tabel 3.15 Struktur Vegetasi Agroforestry Kebun Campuran di sekitar DAS Balangtieng Kabupaten Bulukumba

\begin{tabular}{|c|c|c|c|c|c|c|c|c|}
\hline No & Jenis & $\begin{array}{c}\mathrm{K} \\
\text { (ind/ha) } \\
\end{array}$ & $\begin{array}{l}\text { KR } \\
(\%)\end{array}$ & $\mathrm{F}$ & $\begin{array}{l}\text { FR } \\
(\%)\end{array}$ & $\begin{array}{c}\mathrm{D} \\
\left(\mathrm{m}^{2} / \mathrm{ha}\right)\end{array}$ & $\begin{array}{l}\text { DR } \\
(\%) \\
\end{array}$ & $\begin{array}{l}\text { INP } \\
(\%) \\
\end{array}$ \\
\hline \multicolumn{9}{|c|}{ Semai } \\
\hline 1 & Aren & 3000,00 & 13,71 & 0,20 & 9,09 & - & - & 22,81 \\
\hline 2 & Biti & 125,00 & 0,57 & 0,05 & 2,27 & - & - & 2,84 \\
\hline 3 & Cengkeh & 250,00 & 1,14 & 0,05 & 2,27 & - & - & 3,42 \\
\hline 4 & Cokelat & 1125,00 & 5,14 & 0,10 & 4,55 & - & - & 9,69 \\
\hline 5 & Gamal & 375,00 & 1,71 & 0,05 & 2,27 & - & - & 3,99 \\
\hline 6 & Gmelina & 125,00 & 0,57 & 0,05 & 2,27 & - & - & 2,84 \\
\hline 7 & Jambu Air & 250,00 & 1,14 & 0,05 & 2,27 & - & - & 3,42 \\
\hline 8 & Jarak & 500,00 & 2,29 & 0,05 & 2,27 & - & - & 4,56 \\
\hline 9 & Jejerukan & 125,00 & 0,57 & 0,05 & 2,27 & - & - & 2,84 \\
\hline 10 & Jengkol & 125,00 & 0,57 & 0,05 & 2,27 & - & - & 2,84 \\
\hline 11 & Kadieng & 750,00 & 3,43 & 0,10 & 4,55 & - & - & 7,97 \\
\hline 12 & Kelapa & 125,00 & 0,57 & 0,05 & 2,27 & - & - & 2,84 \\
\hline 13 & Kemiri & 625,00 & 2,86 & 0,05 & 2,27 & - & - & 5,13 \\
\hline 14 & Ketapang & 5000,00 & 22,86 & 0,25 & 11,36 & - & - & 34,22 \\
\hline 15 & Kopi & 3125,00 & 14,29 & 0,35 & 15,91 & - & - & 30,19 \\
\hline 16 & Langsat & 375,00 & 1,71 & 0,05 & 2,27 & - & - & 3,99 \\
\hline 17 & Makaranga & 125,00 & 0,57 & 0,05 & 2,27 & - & - & 2,84 \\
\hline 18 & Mangga & 625,00 & 2,86 & 0,05 & 2,27 & - & - & 5,13 \\
\hline 19 & Nanas & 125,00 & 0,57 & 0,05 & 2,27 & - & - & 2,84 \\
\hline 20 & Nangka & 125,00 & 0,57 & 0,05 & 2,27 & - & - & 2,84 \\
\hline 21 & Petai & 125,00 & 0,57 & 0,05 & 2,27 & - & - & 2,84 \\
\hline 22 & Pinang & 250,00 & 1,14 & 0,05 & 2,27 & - & - & 3,42 \\
\hline 23 & Rambutan & 4250,00 & 19,43 & 0,25 & 11,36 & - & - & 30,79 \\
\hline \multirow[t]{2}{*}{24} & Sirsak & 250,00 & 1,14 & 0,10 & 4,55 & - & - & 5,69 \\
\hline & Jumlah & 21875,00 & 100,00 & 2,20 & 100,00 & - & - & 200,00 \\
\hline \multicolumn{9}{|c|}{ Sapihan } \\
\hline 1 & $\begin{array}{l}\text { Bakang } \\
\text { Kampung }\end{array}$ & 40 & 7,14 & 0,10 & 9,52 & - & - & 16,67 \\
\hline 2 & Cengkeh & 20 & 3,57 & 0,05 & 4,76 & - & - & 8,33 \\
\hline 3 & Coklat & 60 & 10,71 & 0,10 & 9,52 & - & - & 20,24 \\
\hline 4 & Gamal & 80 & 14,29 & 0,15 & 14,29 & - & - & 28,57 \\
\hline 5 & Gmelina & 20 & 3,57 & 0,05 & 4,76 & - & - & 8,33 \\
\hline 6 & Jengkol & 40 & 7,14 & 0,05 & 4,76 & - & - & 11,90 \\
\hline 7 & Kadieng & 20 & 3,57 & 0,05 & 4,76 & - & - & 8,33 \\
\hline 8 & Ketapang & 20 & 3,57 & 0,05 & 4,76 & - & - & 8,33 \\
\hline 9 & Kopi & 160 & 28,57 & 0,25 & 23,81 & - & - & 52,38 \\
\hline 10 & Langsat & 20 & 3,57 & 0,05 & 4,76 & - & - & 8,33 \\
\hline 11 & Rambutan & 40 & 7,14 & 0,10 & 9,52 & - & - & 16,67 \\
\hline \multirow[t]{2}{*}{12} & Suren & 40 & 7,14 & 0,05 & 4,76 & - & - & 11,90 \\
\hline & Jumlah & 560 & 100,00 & 1,05 & 100,00 & - & - & 200,00 \\
\hline \multicolumn{9}{|c|}{ Pancang } \\
\hline 1 & $\begin{array}{l}\text { Bakang } \\
\text { Kampung }\end{array}$ & 5 & 2,08 & 0,05 & 3,57 & 0,02 & 1,66 & 7,32 \\
\hline 2 & Biti & 5 & 2,08 & 0,05 & 3,57 & 0,03 & 3,17 & 8,83 \\
\hline
\end{tabular}




\begin{tabular}{|c|c|c|c|c|c|c|c|c|}
\hline No & Jenis & $\begin{array}{c}\mathrm{K} \\
\text { (ind/ha) }\end{array}$ & $\begin{array}{l}\text { KR } \\
(\%) \\
\end{array}$ & $F$ & $\begin{array}{l}\text { FR } \\
(\%)\end{array}$ & $\begin{array}{c}\mathrm{D} \\
\left(\mathrm{m}^{2} / \mathrm{ha}\right)\end{array}$ & $\begin{array}{l}\text { DR } \\
(\%)\end{array}$ & $\begin{array}{l}\text { INP } \\
(\%)\end{array}$ \\
\hline 3 & Cengkeh & 25 & 10,42 & 0,2 & 14,29 & 0,11 & 10,17 & 34,87 \\
\hline 4 & Coklat & 115 & 47,92 & 0,4 & 28,57 & 0,53 & 49,98 & 126,47 \\
\hline 5 & Dadap & 15 & 6,25 & 0,05 & 3,57 & 0,06 & 5,91 & 15,73 \\
\hline 6 & Gamal & 20 & 8,33 & 0,15 & 10,71 & 0,05 & 4,72 & 23,77 \\
\hline 7 & Jengkol & 5 & 2,08 & 0,05 & 3,57 & 0,02 & 2,17 & 7,83 \\
\hline 8 & Kelapa & 5 & 2,08 & 0,05 & 3,57 & 0,07 & 6,66 & 12,31 \\
\hline 9 & Kopi & 5 & 2,08 & 0,05 & 3,57 & 0,01 & 0,97 & 6,62 \\
\hline 10 & Langsat & 10 & 4,17 & 0,05 & 3,57 & 0,04 & 4,17 & 11,91 \\
\hline 11 & Manggis & 5 & 2,08 & 0,05 & 3,57 & 0,01 & 1,09 & 6,75 \\
\hline 12 & Mete & 10 & 4,17 & 0,1 & 7,14 & 0,06 & 5,60 & 16,91 \\
\hline 13 & Rambutan & 5 & 2,08 & 0,05 & 3,57 & 0,01 & 1,09 & 6,75 \\
\hline 14 & Sirsak & 5 & 2,08 & 0,05 & 3,57 & 0,02 & 1,66 & 7,32 \\
\hline \multirow[t]{2}{*}{15} & Suren & 5 & 2,08 & 0,05 & 3,57 & 0,01 & 0,97 & 6,62 \\
\hline & Jumlah & 240 & 100 & 1,4 & 100,00 & 1,06 & 100,00 & 300,00 \\
\hline \multicolumn{9}{|c|}{ Pohon } \\
\hline 1 & Angsana & 1,25 & 0,32 & 0,05 & 0,90 & 0,01 & 0,08 & 1,29 \\
\hline 2 & Aren & 5,00 & 1,27 & 0,10 & 1,80 & 0,15 & 0,91 & 3,98 \\
\hline 3 & Biti & 18,75 & 4,78 & 0,25 & 4,50 & 0,49 & 3,06 & 12,34 \\
\hline 4 & Cengkeh & 42,50 & 10,83 & 0,45 & 8,11 & 1,00 & 6,19 & 25,13 \\
\hline 5 & Coklat & 63,75 & 16,24 & 0,70 & 12,61 & 0,92 & 5,67 & 34,53 \\
\hline 6 & Durian & 5,00 & 1,27 & 0,15 & 2,70 & 0,08 & 0,48 & 4,46 \\
\hline 7 & $\begin{array}{l}\text { Ficus } \\
\text { Septica }\end{array}$ & 1,25 & 0,32 & 0,05 & 0,90 & 0,02 & 0,11 & 1,33 \\
\hline 8 & Galumpang & 2,50 & 0,64 & 0,10 & 1,80 & 0,58 & 3,57 & 6,01 \\
\hline 9 & Gmelina & 45,00 & 11,46 & 0,30 & 5,41 & 2,92 & 18,09 & 34,96 \\
\hline 10 & Jambu Bol & 2,50 & 0,64 & 0,10 & 1,80 & 0,18 & 1,12 & 3,56 \\
\hline 11 & Jeruk & 1,25 & 0,32 & 0,05 & 0,90 & 0,01 & 0,08 & 1,29 \\
\hline 12 & Kadieng & 1,25 & 0,32 & 0,05 & 0,90 & 0,03 & 0,21 & 1,43 \\
\hline 13 & Kayu Cina & 5,00 & 1,27 & 0,10 & 1,80 & 0,16 & 1,01 & 4,08 \\
\hline 14 & Kedondong & 1,25 & 0,32 & 0,05 & 0,90 & 0,06 & 0,39 & 1,61 \\
\hline 15 & Kelapa & 77,50 & 19,75 & 0,75 & 13,51 & 4,95 & 30,66 & 63,92 \\
\hline 16 & Kemiri & 5,00 & 1,27 & 0,15 & 2,70 & 1,05 & 6,52 & 10,49 \\
\hline 17 & Kenanga & 1,25 & 0,32 & 0,05 & 0,90 & 0,02 & 0,14 & 1,36 \\
\hline 18 & Kepuh & 1,25 & 0,32 & 0,05 & 0,90 & 0,03 & 0,21 & 1,43 \\
\hline 19 & Kisereh & 1,25 & 0,32 & 0,05 & 0,90 & 0,02 & 0,14 & 1,36 \\
\hline 20 & Kopi & 1,25 & 0,32 & 0,05 & 0,90 & 0,03 & 0,18 & 1,40 \\
\hline 21 & Langsat & 40,00 & 10,19 & 0,40 & 7,21 & 0,75 & 4,66 & 22,06 \\
\hline 22 & Mangga & 11,25 & 2,87 & 0,35 & 6,31 & 0,63 & 3,88 & 13,05 \\
\hline 23 & Matoa & 1,25 & 0,32 & 0,05 & 0,90 & 0,01 & 0,08 & 1,30 \\
\hline 24 & Mete & 3,75 & 0,96 & 0,10 & 1,80 & 0,06 & 0,40 & 3,16 \\
\hline 25 & Rambutan & 30,00 & 7,64 & 0,45 & 8,11 & 0,61 & 3,74 & 19,50 \\
\hline 26 & $\begin{array}{l}\text { Homalantus } \\
\text { sp. }\end{array}$ & 1,25 & 0,32 & 0,05 & 0,90 & 0,06 & 0,39 & 1,61 \\
\hline 27 & Rao & 1,25 & 0,32 & 0,05 & 0,90 & 0,10 & 0,62 & 1,84 \\
\hline 28 & Sengon & 1,25 & 0,32 & 0,05 & 0,90 & 0,30 & 1,84 & 3,06 \\
\hline 29 & Sentul & 1,25 & 0,32 & 0,05 & 0,90 & 0,02 & 0,11 & 1,33 \\
\hline
\end{tabular}




\begin{tabular}{clccccccc}
\hline No & \multicolumn{1}{c}{ Jenis } & $\begin{array}{c}\text { K } \\
\text { (ind/ha) }\end{array}$ & $\begin{array}{c}\text { KR } \\
(\%)\end{array}$ & $F$ & $\begin{array}{c}\text { FR } \\
(\%)\end{array}$ & $\begin{array}{c}\text { D } \\
\left(\mathrm{m}^{2} / \mathrm{ha}\right)\end{array}$ & $\begin{array}{c}\text { DR } \\
(\%)\end{array}$ & $\begin{array}{c}\text { INP } \\
(\%)\end{array}$ \\
\hline 30 & Sp1 & 2,50 & 0,64 & 0,10 & 1,80 & 0,03 & 0,19 & 2,63 \\
31 & Sp6 & 1,25 & 0,32 & 0,05 & 0,90 & 0,36 & 2,20 & 3,42 \\
32 & Spatodea & 2,50 & 0,64 & 0,10 & 1,80 & 0,03 & 0,19 & 2,63 \\
33 & Petai & 8,75 & 2,23 & 0,05 & 0,90 & 0,42 & 2,62 & 5,75 \\
34 & Suren & 1,25 & 0,32 & 0,05 & 0,90 & 0,01 & 0,06 & 1,28 \\
35 & Waru & 1,25 & 0,32 & 0,05 & 0,90 & 0,03 & 1,19 & 1,41 \\
& Jumlah & 392,50 & 100,00 & 5,55 & 100,00 & 16,16 & 100,00 & 300,00 \\
\hline
\end{tabular}

Tabel 3.15 menunjukkan pada tingkat semai jenis tumbuhan di kebun campuran lebih banyak dibandingkan pola agroforestry lainnya. Tumbuhan pada tingkat semai cenderung didominasi oleh jenis ketapang (INP 34,22 \%), rambutan (INP 30,79\%) dan kopi (INP 30,19\%). Anakan ketapang banyak dijumpai pada kebun campuran di wilayah hilir DAS, sedangkan rambutan di wilayah tengah dan kopi di wilayah hulu. Meskipun dominasinya masih rendah tetapi secara keseluruhan kerapatan semai di kebun campuran cukup tinggi yaitu mencapai $21.875 \mathrm{ind} / \mathrm{ha}$.

Sementara itu pada tingkat sapihan terjadi penurunan jumlah jenis dari tingkat semai menjadi 12 jenis namun sebagian besar (83\%) merupakan jenis yang sama dengan tingkat semai. Jenis yang tidak dijumpai pada tingkat semai adalah suren dan waru. Jenis suren banyak ditanam oleh masyarakat di wilayah hulu seperti di wilayah Kindang meskipun tergolong jenis baru.
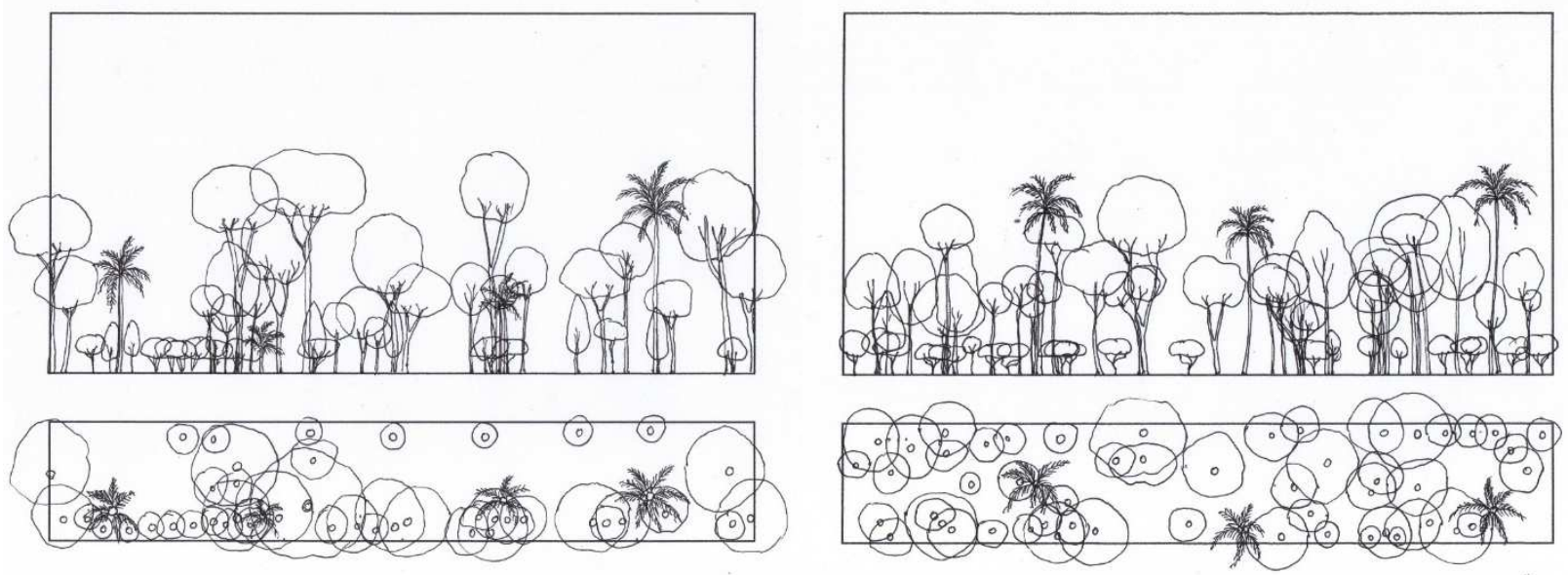

Gambar 3.8 Diagram profil tegakan pada sistem kebun campuran

Pada tingkat pancang dijumpai sebanyak 15 jenis dengan dominasi jenis coklat cukup besar (INP $126,27 \%$ ) dan sebanyak 50\% jenisnya sama dengan tingkat sapihan. Dominasi coklat di kebun campuran lebih banyak di wilayah tengah. Hal tersebut dapat mengindikasikan umur coklat belum tua dan masih menjadi komoditi transisi dari kebun campuran menjadi kebun yang didominasi oleh jenis perennial crop. 
Struktur vegetasi tingkat pohon pada kebun campuran lebih beragam dibandingkan tingkat pertumbuhan di bawahnya (semai, sapihan, pancang) yaitu sebanyak 35 jenis yang didominasi oleh jenis kelapa (INP 63,92 \%). Meskipun demikian sebagian besar jenis tumbuhan tingkat pohon tergolong tumbuhan penghasil kayu pertukangan $(48,57 \%)$.

\section{Agroforestry di Hutan Sekunder}

Hutan sekunder (log over area) yang menjadi lokasi plot pengamatan adalah termasuk hutan produksi terbatas. Hutan tersebut telah mengalami proses rehabilitasi dengan jenis sengon dan dimanfaatkan pula oleh masyarakat sebagai kebun. Komposisi jenis tumbuhan pada hutan sekunder di sekitar DAS Balangtieng disajikan pada Tabel 3.16.

Tabel 3.16 Kerapatan populasi jenis tumbuhan berdasarkan tingkat pertumbuhan di hutan sekunder sekitar DAS Balangtieng Kabupaten Bulukumba

\begin{tabular}{|c|c|c|c|c|c|c|c|}
\hline \multirow[t]{2}{*}{ No } & \multirow{2}{*}{$\begin{array}{l}\text { Nama } \\
\text { Lokal }\end{array}$} & \multirow{2}{*}{ Nama Latin } & \multicolumn{4}{|c|}{ Kerapatan populasi (indv./ha) } & \multirow{2}{*}{ Kategori } \\
\hline & & & Semai & Sapihan & Pancang & Pohon & \\
\hline 1 & Kayu afrika & Maesopsis eminii & - & - & - & 1,67 & $\mathrm{~K}$ \\
\hline 2 & Alpukat & Persea americana & - & - & - & 1,67 & $\mathrm{HB}$ \\
\hline 3 & Asah & Lithocarpus celebicus & - & 53,33 & - & 18,33 & KA \\
\hline 4 & Bisuhu & $\begin{array}{l}\text { Magnolia sumatrana var. } \\
\text { glauca }\end{array}$ & 166,67 & - & - & 3,33 & $\mathrm{KA}$ \\
\hline 5 & Biti & Vitex cofassus & 1500,00 & - & - & 3,33 & $\mathrm{KA}$ \\
\hline 6 & Buto & Enterolobium cyclocarpum & - & - & - & 1,67 & $\mathrm{KA}$ \\
\hline 7 & Cengkeh & Syzygium aromaticum & 500,00 & 160,00 & 66,67 & 1,67 & $\mathrm{PC}$ \\
\hline 8 & Coklat & Theobroma cacao & - & - & 33,33 & 15,00 & $\mathrm{PC}$ \\
\hline 9 & Copeng & - & 1333,33 & - & - & - & $\mathrm{KA}$ \\
\hline 10 & Dadap & Erytrina variegata & - & - & - & 10,00 & $\mathrm{KA}$ \\
\hline 11 & Durian & Durio zibhetinus & 166,67 & - & 6,67 & 6,67 & $\mathrm{HB}$ \\
\hline 12 & Gaharu & Aquilaria malaccensis & 166,67 & - & - & - & HR \\
\hline 13 & Gamal & Gliricidia maculata & - & 26,67 & - & 11,67 & MPTS \\
\hline 14 & Kayu Cina & Lannea coromandelica & - & 26,67 & - & - & MPTS \\
\hline 15 & Kayu Hulo & Pterocarpus indicus & 166.67 & - & - & - & $\mathrm{KA}$ \\
\hline 16 & Kopi & Coffea sp. & 19000,00 & 640,00 & 706,67 & 15,00 & $\mathrm{PC}$ \\
\hline 17 & Langsat & Lansium domesticum & 333,33 & 53,33 & 40,00 & 8,33 & $\mathrm{HB}$ \\
\hline 18 & Laniki & Wrightia pubescens & 666,67 & - & - & 1,67 & $\mathrm{KA}$ \\
\hline 19 & Mahoni & Swietenia macrophylla & 500,00 & 80,00 & 20,00 & 11,67 & $\mathrm{~K}$ \\
\hline 20 & Makaranga & Macaranga tanarius & 166,67 & - & - & - & $\mathrm{KA}$ \\
\hline 21 & Mangga & Mangifera indica & 333,33 & - & - & 3,33 & $\mathrm{HB}$ \\
\hline 22 & Mete & Anacardium occidentale & - & - & - & 3,33 & $\mathrm{HB}$ \\
\hline 23 & Pandan & Pandanus tectorius & - & - & - & 1,67 & $\mathrm{HA}$ \\
\hline 24 & Petai & Parkia speciosa & 1166,67 & & 13,33 & 13,33 & $\mathrm{HB}$ \\
\hline 25 & Picung & Pangium edule & - & - & - & 1,67 & $\mathrm{HB}$ \\
\hline 26 & Pulai & Alstonia scholaris & 1333,33 & - & - & 8,33 & $\mathrm{KA}$ \\
\hline 27 & Rambutan & Nephelium lapacheum & 19333,33 & - & - & 6,67 & $\mathrm{HB}$ \\
\hline 28 & $\begin{array}{l}\text { Rambutan } \\
\text { Hutan }\end{array}$ & Nephelium ramboutan-ake & - & - & 20,00 & 21,67 & $\mathrm{HB}$ \\
\hline
\end{tabular}




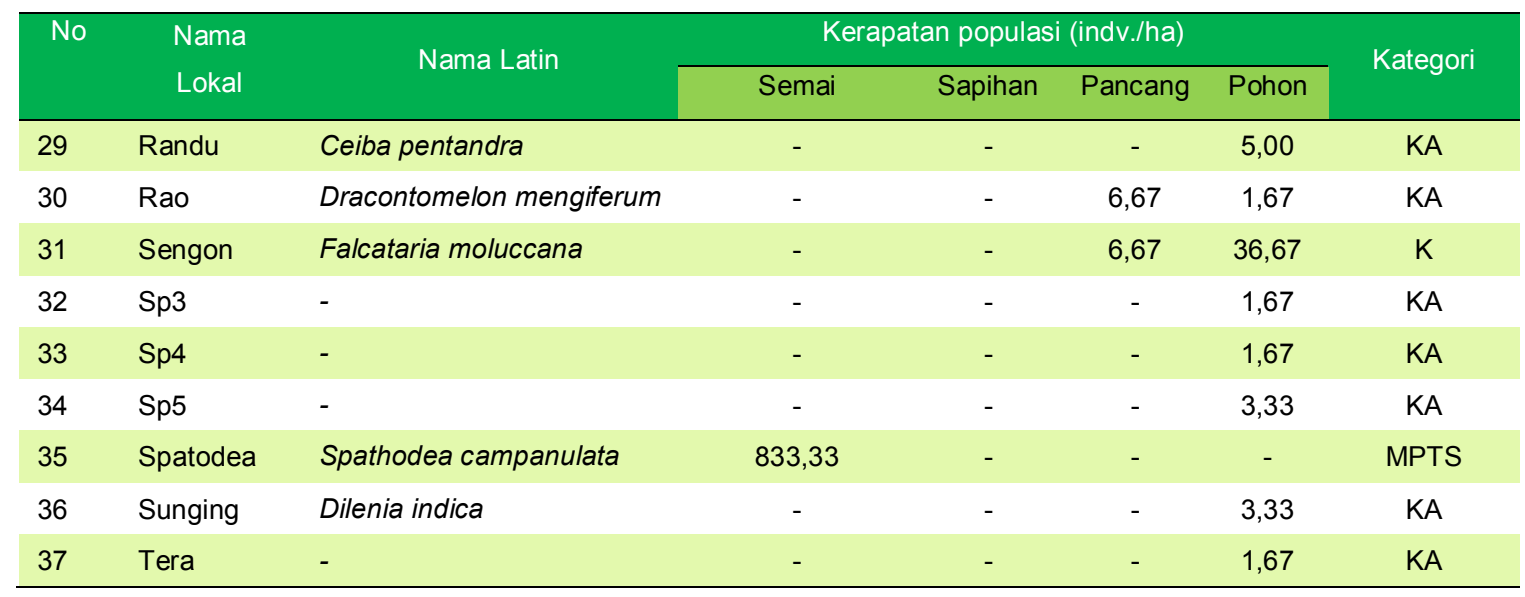

Keterangan: HB = HHBK Buah; HP = HHBK Pat; HM = HHBK Minyak; HG = HHBK Getah; MPTS = Multipurpose Tree Species; K = Kayu Pertukangan; KA = Kayu Alam; PC = Perenial Crop

Tabel 3.16 menunjukkan komposisi jenis tumbuhan pepohonan pada hutan sekunder terdiri dari 37 jenis meliputi 19 jenis semai, 7 jenis sapihan, 11 jenis pancang dan 31 jenis pohon. Sebagian besar tumbuhan tergolong kayu alam $(45,9)$ asli dan tumbuhan yang tergolong HHBK buah-buahan hasil penanaman baik kegiatan rehabilitasi lahan maupun inisiatif pribadi masyarakat penggarap. Kegiatan penggarap dalam menanam kopi di bawah tegakan hutan membentuk agroforestry kopi dan tanaman HHBK buah-buahan.

Tabel 3.17 Struktur Vegetasi hutan sekunder di sekitar DAS Balangtieng Kabupaten Bulukumba

\begin{tabular}{|c|c|c|c|c|c|c|c|c|}
\hline No & Jenis & $\begin{array}{c}\mathrm{K} \\
\text { (ind./ha) }\end{array}$ & $\begin{array}{l}\text { KR } \\
(\%)\end{array}$ & $F$ & $\begin{array}{l}\text { FR } \\
(\%)\end{array}$ & $\begin{array}{c}\mathrm{D} \\
(\mathrm{m} 2 / \mathrm{ha})\end{array}$ & $\begin{array}{l}\text { DR } \\
(\%)\end{array}$ & $\begin{array}{l}\text { INP } \\
(\%)\end{array}$ \\
\hline \multicolumn{9}{|l|}{ Semai } \\
\hline 1 & Bisuhu & 166,67 & 0,34 & 0,07 & 2,78 & - & - & 3,12 \\
\hline 2 & Biti & 1500,00 & 3,08 & 0,07 & 2,78 & - & - & 5,86 \\
\hline 3 & Cengkeh & 500,00 & 1,03 & 0,13 & 5,56 & - & - & 6,58 \\
\hline 4 & Copeng & 1333,33 & 2,74 & 0,07 & 2,78 & - & - & 5,52 \\
\hline 5 & Durian & 166,67 & 0,34 & 0,07 & 2,78 & - & - & 3,12 \\
\hline 6 & Gaharu & 166,67 & 0,34 & 0,07 & 2,78 & - & - & 3,12 \\
\hline 7 & Gamal & 166,67 & 0,34 & 0,07 & 2,78 & - & - & 3,12 \\
\hline 8 & Kayu Hulo (angsana) & 166,67 & 0,34 & 0,07 & 2,78 & - & - & 3,12 \\
\hline 9 & Kopi & $19.000,00$ & 39,04 & 0,60 & 25,00 & - & - & 64,04 \\
\hline 10 & Langsat & 333,33 & 0,68 & 0,07 & 2,78 & - & - & 3,46 \\
\hline 11 & Laniki & 666,67 & 1,37 & 0,07 & 2,78 & - & - & 4,15 \\
\hline 12 & Mahoni & 500,00 & 1,03 & 0,13 & 5,56 & - & - & 6,58 \\
\hline 13 & Makaranga & 166,67 & 0,34 & 0,07 & 2,78 & - & - & 3,12 \\
\hline 14 & Mangga & 333,33 & 0,68 & 0,13 & 5,56 & - & - & 6,24 \\
\hline 15 & Mete & 833,33 & 1,71 & 0,13 & 5,56 & - & - & 7,27 \\
\hline 16 & Petai & 1166,67 & 2,40 & 0,07 & 2,78 & - & - & 5,18 \\
\hline 17 & Pulai & 1333,33 & 2,74 & 0,07 & 2,78 & - & - & 5,52 \\
\hline 18 & Rambutan & $19.333,33$ & 39,73 & 0,40 & 16,67 & - & - & 56,39 \\
\hline \multirow[t]{2}{*}{19} & Spatodea & 833,33 & 1,71 & 0,07 & 2,78 & - & - & 4,49 \\
\hline & Jumlah & $48.666,67$ & 100,00 & 2,40 & 100,00 & - & - & 200,00 \\
\hline
\end{tabular}




\begin{tabular}{|c|c|c|c|c|c|c|c|c|}
\hline No & Jenis & $\begin{array}{c}\mathrm{K} \\
\text { (ind./ha) }\end{array}$ & $\begin{array}{l}\text { KR } \\
(\%) \\
\end{array}$ & $\mathrm{F}$ & $\begin{array}{l}\text { FR } \\
(\%)\end{array}$ & $\begin{array}{c}\mathrm{D} \\
\text { (m2/ha) }\end{array}$ & $\begin{array}{l}\text { DR } \\
(\%) \\
\end{array}$ & $\begin{array}{l}\text { INP } \\
(\%) \\
\end{array}$ \\
\hline \multicolumn{9}{|l|}{ Sapihan } \\
\hline 1 & Asah & 53,33 & 4,44 & 0,13 & 10,00 & - & - & 14,44 \\
\hline 2 & Cengkeh & 160,00 & 13,33 & 0,27 & 20,00 & - & - & 33,33 \\
\hline 3 & Gamal & 186,67 & 15,56 & 0,20 & 15,00 & - & - & 30,56 \\
\hline 4 & Kayu Cina & 26,67 & 2,22 & 0,07 & 5,00 & - & - & 7,22 \\
\hline 5 & Kopi & 640,00 & 53,33 & 0,47 & 35,00 & - & - & 88,33 \\
\hline 6 & Langsat & 53,33 & 4,44 & 0,07 & 5,00 & - & - & 9,44 \\
\hline \multirow[t]{2}{*}{7} & Mahoni & 80,00 & 6,67 & 0,13 & 10,00 & - & - & 16,67 \\
\hline & Jumlah & $1.200,00$ & 100,00 & 1,33 & 100,00 & - & - & 200,00 \\
\hline \multicolumn{9}{|c|}{ Pancang } \\
\hline 1 & Cengkeh & 66,67 & 6,17 & 0,40 & 17,14 & 0,27 & 6,65 & 29,97 \\
\hline 2 & Coklat & 33,33 & 3,09 & 0,20 & 8,57 & 0,12 & 3,02 & 14,68 \\
\hline 3 & Durian & 6,67 & 0,62 & 0,07 & 2,86 & 0,01 & 0,30 & 3,77 \\
\hline 4 & Gamal & 160,00 & 14,81 & 0,33 & 14,29 & 0,75 & 18,66 & 47,76 \\
\hline 5 & Kopi & 706,67 & 65,43 & 0,60 & 25,71 & 2,34 & 58,62 & 149,77 \\
\hline 6 & Langsat & 40,00 & 3,70 & 0,20 & 8,57 & 0,24 & 5,99 & 18,26 \\
\hline 7 & Mahoni & 20,00 & 1,85 & 0,13 & 5,71 & 0,08 & 2,07 & 9,63 \\
\hline 8 & Petai & 13,33 & 1,23 & 0,07 & 2,86 & 0,07 & 1,70 & 5,79 \\
\hline 9 & Rambutan Hutan & 20,00 & 1,85 & 0,20 & 8,57 & 0,06 & 1,46 & 11,88 \\
\hline 10 & Rao & 6,67 & 0,62 & 0,07 & 2,86 & 0,05 & 1,19 & 4,67 \\
\hline \multirow[t]{2}{*}{11} & Sengon & 6,67 & 0,62 & 0,07 & 2,86 & 0,01 & 0,34 & 3,81 \\
\hline & Jumlah & $1.080,00$ & 100,00 & 2,33 & 100,00 & 4,00 & 100,00 & 300,00 \\
\hline \multicolumn{9}{|l|}{ Pohon } \\
\hline 1 & Kayu afrika & 1,67 & 0,74 & 0,07 & 1,23 & 0,19 & 0,95 & 2,92 \\
\hline 2 & Alpukat & 1,67 & 0,74 & 0,07 & 1,23 & 0,02 & 0,09 & 2,06 \\
\hline 3 & Asah & 18,33 & 8,09 & 0,33 & 6,17 & 3,79 & 18,47 & 32,73 \\
\hline 4 & Bisuhu & 3,33 & 1,47 & 0,13 & 2,47 & 0,66 & 3,21 & 7,15 \\
\hline 5 & Biti & 3,33 & 1,47 & 0,07 & 1,23 & 0,18 & 0,90 & 3,60 \\
\hline 6 & Buto & 1,67 & 0,74 & 0,07 & 1,23 & 0,23 & 1,13 & 3,10 \\
\hline 7 & Cengkeh & 1,67 & 0,74 & 0,07 & 1,23 & 0,02 & 0,08 & 2,05 \\
\hline 8 & Coklat & 15,00 & 6,62 & 0,27 & 4,94 & 0,18 & 0,88 & 12,44 \\
\hline 9 & Dadap & 10,00 & 4,41 & 0,13 & 2,47 & 0,68 & 3,33 & 10,21 \\
\hline 10 & Durian & 6,67 & 2,94 & 0,27 & 4,94 & 0,20 & 0,97 & 8,85 \\
\hline 11 & Gamal & 11,67 & 5,15 & 0,13 & 2,47 & 0,12 & 0,56 & 8,18 \\
\hline 12 & Kopi & 15,00 & 6,62 & 0,27 & 4,94 & 0,23 & 1,12 & 12,68 \\
\hline 13 & Langsat & 8,33 & 3,68 & 0,20 & 3,70 & 0,09 & 0,44 & 7,82 \\
\hline 14 & Laniki & 1,67 & 0,74 & 0,07 & 1,23 & 0,12 & 0,61 & 2,58 \\
\hline 15 & Mahoni & 11,67 & 5,15 & 0,27 & 4,94 & 0,18 & 0,86 & 10,94 \\
\hline 16 & Mangga & 3,33 & 1,47 & 0,13 & 2,47 & 0,09 & 0,46 & 4,40 \\
\hline 17 & Mete & 3,33 & 1,47 & 0,07 & 1,23 & 0,30 & 1,44 & 4,15 \\
\hline 18 & Pandan & 1,67 & 0,74 & 0,07 & 1,23 & 0,24 & 1,18 & 3,15 \\
\hline 19 & Petai & 13,33 & 5,88 & 0,33 & 6,17 & 0,33 & 1,63 & 13,68 \\
\hline 20 & Picung & 1,67 & 0,74 & 0,07 & 1,23 & 0,11 & 0,51 & 2,48 \\
\hline 21 & Pulai & 8,33 & 3,68 & 0,27 & 4,94 & 1,65 & 8,05 & 16,66 \\
\hline
\end{tabular}




\begin{tabular}{llccccccc}
\hline No & \multicolumn{1}{c}{ Jenis } & $\begin{array}{c}\mathrm{K} \\
\text { (ind./ha) }\end{array}$ & $\begin{array}{c}\mathrm{KR} \\
(\%)\end{array}$ & $\mathrm{F}$ & $\begin{array}{c}\mathrm{FR} \\
(\%)\end{array}$ & $\begin{array}{c}\mathrm{D} \\
(\mathrm{m} 2 / \mathrm{ha})\end{array}$ & $\begin{array}{c}\mathrm{DR} \\
(\%)\end{array}$ & $\begin{array}{c}\text { INP } \\
(\%)\end{array}$ \\
\hline 22 & Rambutan & 6,67 & 2,94 & 0,27 & 4,94 & 0,16 & 0,79 & 8,66 \\
23 & Rambutan Hutan & 21,67 & 9,56 & 0,53 & 9,88 & 3,07 & 14,96 & 34,40 \\
24 & Randu & 5,00 & 2,21 & 0,13 & 2,47 & 1,54 & 7,53 & 12,21 \\
25 & Rao & 1,67 & 0,74 & 0,07 & 1,23 & 0,03 & 0,17 & 2,14 \\
26 & Sengon & 36,67 & 16,18 & 0,67 & 12,35 & 5,23 & 25,48 & 54,00 \\
27 & Sp3 & 1,67 & 0,74 & 0,07 & 1,23 & 0,08 & 0,39 & 2,36 \\
28 & Sp4 & 1,67 & 0,74 & 0,07 & 1,23 & 0,17 & 0,81 & 2,78 \\
29 & Sp5 & 3,33 & 1,47 & 0,13 & 2,47 & 0,14 & 0,66 & 4,60 \\
30 & Sunging/Dillenia & 3,33 & 1,47 & 0,07 & 1,23 & 0,29 & 1,41 & 4,12 \\
31 & Tera (Ficus sp.) & 1,67 & 0,74 & 0,07 & 1,23 & 0,19 & 0,95 & 2,92 \\
& Jumlah & 226,67 & 100,00 & 5,40 & 100,00 & 20,52 & 100,00 & 300,00 \\
\hline
\end{tabular}

Keterangan: $\quad \mathrm{K}=$ Kerapatan; KR = Kerapatan Relatif; F = Frekuensi; FR = Frekuensi Relatif; $\mathrm{D}=$ Dominansi; DR = Dominansi Relatif; INP = Indek Nilai Penting

Tabel 3.17 menunjukkan tingkat semai didominasi oleh jenis kopi (INP 64,04 \%) dan rambutan (INP $56,39 \%$ ). Dominasi tersebut disebabkan oleh tingkat kerapatannya yang tinggi. Sebagian besar semai tergolong jenis buah-buahan meskipun masih dijumpai beberapa semai jenis tanaman hutan seperti pulai, biti, bisuhu, laniki, kayu hulo dan makaranga. Sementara itu pada tingkat sapihan sebagian besar tergolong jenis tanaman budidaya buah-buahan dan hanya satu jenis yang tergolong tumbuhan hutan alam yaitu asah.

Jenis Kopi mendominasi tingkat pertumbuhan sapihan (INP 88,33 \%) dan pancang (INP 149,77 \%). Dominasi kopi pada tingkat pertumbuhan pancang, sapihan dan semai menunjukkan pola kombinasi agroforestry di hutan alam sekunder dengan komoditi utama tumbuhan bawah berupa kopi (Gambar 3.9). Selain itu dominasi pada tingkat pertumbuhan semai dan pancang disebabkan tidak adanya pengelolaan yang intensif sehingga biji kopi dapat tumbuh secara alami bahkan banyak masyarakat yang tidak memanen kopi disebabkan harganya yang tidak ekonomis.
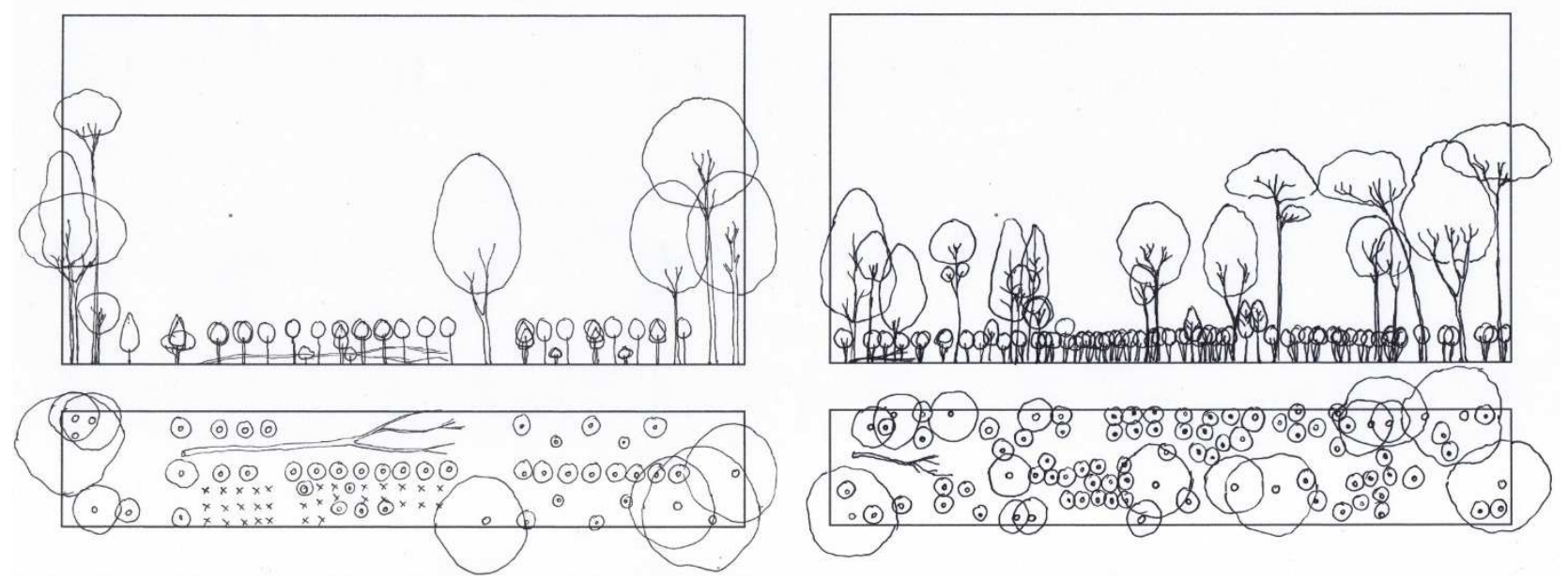

Gambar 3.9 Diagram profil tegakan pada hutan sekunder di dataran rendah (kiri) dan dataran tinggi (kanan)

Adapun struktur tegakan pada tingkat pohon didominasi oleh jenis sengon (INP 54,0) meskipun sebagian besar pohon tergolong jenis buah-buahan budidaya atau sengaja ditanam oleh masyarakat 
sebagaimana Tabel 3.17. Dominasi sengon terhadap tumbuhan lainnnya adalah karena nilai dominansinya (basal area) yang besar yaitu $5,23 \mathrm{~m}^{2} /$ ha. Meskipun demikian pada hutan sekunder masih dijumpai pohon asli hutan alam setempat dengan luas bidang dasar cukup besar seperti asah $\left(3,79 \mathrm{~m}^{2} / \mathrm{ha}\right)$, rambutan hutan $\left(3,07 \mathrm{~m}^{2} / \mathrm{ha}\right)$ dan pulai $\left(1,65 \mathrm{~m}^{2} / \mathrm{ha}\right)$.

\section{Hutan Alam}

Analisis vegetasi di hutan alam bertujuan untuk melihat biodiversity spot utama sebagai pembanding eksistensi jenis alam di kawasan agroforestry khususnya yang berada di wilayah hulu DAS

Balangtieng. Komposisi jenis tumbuhan yang diperoleh pada lokasi plot pengamatan belum mewakili komunitas hutan alam karena minimnya jumlah plot, namun dapat menjadi pembanding untuk melihat jenis-jenis asli di hutan alam.

Tabel 3.18 menunjukkan komposisi jenis tumbuhan pepohonan di hutan alam yang tergolong hutan lindung berjumlah 30 jenis yang tersebar pada berbagai tingkat pertumbuhan meliputi 6 jenis semai, 7 jenis sapihan, 8 jenis pancang dan 22 jenis pohon. Sebagian besar jenis tumbuhan tergolong kayu hutan alam. letak kawasan hutan alam berbatasan dengan kebun masyarakat namun masih terjaga keasliannya (Gambar 3.10).

Tabel 3.18 Kerapatan populasi jenis tumbuhan berdasarkan tingkat pertumbuhan di hutan alam sekitar DAS Balangtieng Kabupaten Bulukumba

\begin{tabular}{|c|c|c|c|c|c|c|c|}
\hline \multirow{2}{*}{ No } & \multirow{2}{*}{ Jenis } & \multirow{2}{*}{ Nama Latin } & \multicolumn{4}{|c|}{ Kerapatan populasi (ind./ha) } & \multirow{2}{*}{ Kategor } \\
\hline & & & semai & sapihan & pancang & pohon & \\
\hline 1 & Ahu-Ahu & - & - & - & - & 5 & KA \\
\hline 2 & Asah & Lithocarpus celebicus & 14000 & 1920 & 40 & 225 & $\mathrm{KA}$ \\
\hline 3 & Bakang & Litsea sp. & - & - & - & 10 & KA \\
\hline 4 & Birupa & $\begin{array}{l}\text { Magnolia sumatrana var. } \\
\text { glauca }\end{array}$ & - & 240 & - & - & $\mathrm{KA}$ \\
\hline 5 & Bune & Antidesma bunius & - & - & - & 5 & $\mathrm{KA}$ \\
\hline 6 & Buno Bampo & - & - & 240 & 20 & 10 & $\mathrm{KA}$ \\
\hline 7 & Ficus & Ficus sp. & - & - & - & 5 & KA \\
\hline 8 & Jenitri & Elaeocarpus sp. & - & - & - & 20 & $\mathrm{KA}$ \\
\hline 9 & Gora-Gora & Psychotria divergens & 5500 & - & - & - & $\mathrm{KA}$ \\
\hline 10 & Pansor & Ficus callosa & - & - & - & 15 & $\mathrm{KA}$ \\
\hline 11 & Kacunu & - & - & - & - & 15 & $\mathrm{KA}$ \\
\hline 12 & Kaliandra & Calliandra callothyrus & 5000 & - & - & - & $\mathrm{KA}$ \\
\hline 13 & Kampala & Platea excelsa & - & - & - & 10 & $\mathrm{KA}$ \\
\hline 14 & Kopi & Coffea sp. & 2000 & 320 & 20 & - & $\mathrm{PC}$ \\
\hline 15 & Lama Rasikarpa & - & - & 240 & 40 & 5 & $\mathrm{KA}$ \\
\hline 16 & Lento-Lento & - & - & 80 & - & - & $\mathrm{KA}$ \\
\hline 17 & Lola & - & 500 & - & - & - & $\mathrm{KA}$ \\
\hline 18 & Maha & - & - & - & - & 10 & $\mathrm{KA}$ \\
\hline 19 & Nato & Magnolia liliifera & - & 400 & 120 & - & $\mathrm{KA}$ \\
\hline 20 & Nosong & - & - & - & - & 15 & $\mathrm{KA}$ \\
\hline
\end{tabular}




\begin{tabular}{|c|c|c|c|c|c|c|c|}
\hline \multirow{2}{*}{ No } & \multirow{2}{*}{ Jenis } & \multirow{2}{*}{ Nama Latin } & \multicolumn{4}{|c|}{ Kerapatan populasi (ind./ha) } & \multirow{2}{*}{ Kategor } \\
\hline & & & semai & sapihan & pancang & pohon & \\
\hline 21 & Nyatoh & Palaquium sp. & - & - & - & 20 & $\mathrm{KA}$ \\
\hline 22 & Pakis Haji & Cycas sp. & - & - & - & 10 & $\mathrm{KA}$ \\
\hline 23 & Pala Hutan & Gymnachantera sp. & - & - & 20 & 25 & KA \\
\hline 24 & Pandan & Pandanus tectorius & - & - & 20 & 10 & $\mathrm{KA}$ \\
\hline 25 & Rambutan & Nephelium lapacheum & - & - & - & 10 & $\mathrm{KA}$ \\
\hline 26 & Sawo Hutan & Tristiropsis canarioides & - & - & 40 & 5 & $\mathrm{KA}$ \\
\hline 27 & sp7 & - & - & - & - & 5 & KA \\
\hline 28 & sp8 & - & 1000 & - & - & - & $\mathrm{KA}$ \\
\hline 29 & Sugi Manae & - & - & - & - & 40 & $\mathrm{KA}$ \\
\hline 30 & Tambun-Tambun & - & - & - & - & 5 & $\mathrm{KA}$ \\
\hline
\end{tabular}

Keterangan: HB = HHBK Buah; HP = HHBK Pat; HM = HHBK Minyak; HG = HHBK Getah; MPTS = Multipurpose Tree Species; K = Kayu Pertukangan; KA = Kayu Alam; PC = Perenial Crop

Tabel 3.18 menunjukkan hanya satu jenis tumbuhan kayu hutan alam yang kerapatan jenisnya tersebar pada semua tingkat pertumbuhan yaitu Asah. Asah (Lithocarpus celebicus) merupakan kayu alam yang sebarannya masih dijumpai di hutan sekunder atau hutan produksi terbatas dengan dominansi tergolong besar. Menurut masyarakat setempat jenis kayu asah tergolong kayu keras dan dimanfaatkan sebagai kayu pertukangan.

Tabel 3.19 Struktur Vegetasi hutan alam di sekitar DAS Balangtieng Kabupaten Bulukumba

\begin{tabular}{|c|c|c|c|c|c|c|c|c|}
\hline No & Jenis & $\begin{array}{c}\mathrm{K} \\
\text { (ind/ha) }\end{array}$ & $\begin{array}{l}\text { KR } \\
(\%) \\
\end{array}$ & $\mathrm{F}$ & $\begin{array}{l}\text { FR } \\
(\%) \\
\end{array}$ & $\begin{array}{c}\text { D } \\
\left(\mathrm{m}^{2} / \mathrm{ha}\right)\end{array}$ & $\begin{array}{l}\text { DR } \\
(\%) \\
\end{array}$ & $\begin{array}{l}\text { INP } \\
(\%) \\
\end{array}$ \\
\hline \multicolumn{9}{|c|}{ Semai } \\
\hline 1 & Asah & 14000 & 50,00 & 1,00 & 38,46 & - & - & 88,46 \\
\hline 2 & Gora-gora & 5500 & 19,64 & 0,80 & 30,77 & - & - & 50,41 \\
\hline 3 & Kaliandra & 5000 & 17,86 & 0,20 & 7,69 & - & - & 25,55 \\
\hline 4 & Kopi & 2000 & 7,14 & 0,20 & 7,69 & - & - & 14,84 \\
\hline 5 & Lola & 500 & 1,79 & 0,20 & 7,69 & - & - & 9,48 \\
\hline \multirow[t]{2}{*}{6} & Sp8 & 1000 & 3,57 & 0,20 & 7,69 & - & - & 11,26 \\
\hline & Jumlah & 28.000 & 100,00 & 2,60 & 100,00 & - & - & 200,00 \\
\hline \multicolumn{9}{|c|}{ Sapihan } \\
\hline 1 & Asah & 1920 & 55,81 & 0,8 & 28,57 & - & - & 84,39 \\
\hline 2 & Birupa & 240 & 6,98 & 0,2 & 7,14 & - & - & 14,12 \\
\hline 3 & Buno bampo & 240 & 6,98 & 0,2 & 7,14 & - & - & 14,12 \\
\hline 4 & Kopi & 320 & 9,30 & 0,2 & 7,14 & - & - & 16,45 \\
\hline 5 & Lama rasikarpa & 240 & 6,98 & 0,4 & 14,29 & - & - & 21,26 \\
\hline 6 & Lento-lento & 80 & 2,33 & 0,2 & 7,14 & - & - & 9,47 \\
\hline \multirow[t]{2}{*}{7} & Nato & 400 & 11,63 & 0,8 & 28,57 & - & - & 40,20 \\
\hline & Jumlah & 3440 & 100 & 2,8 & 100,00 & - & - & 200,00 \\
\hline \multicolumn{9}{|c|}{ Pancang } \\
\hline 1 & Asah & 40 & 12,5 & 0,2 & 11,11 & 0,23 & 15,52 & 39,13 \\
\hline 2 & Buno bampo & 20 & 6,25 & 0,2 & 11,11 & 0,11 & 7,26 & 24,62 \\
\hline 3 & Kopi & 20 & 6,25 & 0,2 & 11,11 & 0,12 & 7,83 & 25,19 \\
\hline
\end{tabular}




\begin{tabular}{|c|c|c|c|c|c|c|c|c|}
\hline No & Jenis & $\begin{array}{c}\mathrm{K} \\
\text { (ind/ha) }\end{array}$ & $\begin{array}{l}\text { KR } \\
(\%) \\
\end{array}$ & $F$ & $\begin{array}{l}\text { FR } \\
(\%) \\
\end{array}$ & $\begin{array}{c}D \\
\left(m^{2} / h a\right)\end{array}$ & $\begin{array}{l}\text { DR } \\
(\%) \\
\end{array}$ & $\begin{array}{l}\text { INP } \\
(\%) \\
\end{array}$ \\
\hline 4 & Lama rasikarpa & 40 & 12,5 & 0,2 & 11,11 & 0,10 & 7,04 & 30,66 \\
\hline 5 & Nato & 120 & 37,5 & 0,4 & 22,22 & 0,57 & 38,28 & 98,00 \\
\hline 6 & Pala hutan & 20 & 6,25 & 0,2 & 11,11 & 0,15 & 10,32 & 27,68 \\
\hline 7 & Pandan & 20 & 6,25 & 0,2 & 11,11 & 0,10 & 6,71 & 24,07 \\
\hline \multirow[t]{2}{*}{8} & Sawo hutan & 40 & 12,5 & 0,2 & 11,11 & 0,10 & 7,04 & 30,66 \\
\hline & Jumlah & 320 & 100 & 1,8 & 100,00 & 1,48 & 100,00 & 300,00 \\
\hline \multicolumn{9}{|c|}{ Pohon } \\
\hline 1 & Ahu-ahu & 5 & 1,04 & 0,20 & 2,63 & 0,14 & 0,42 & 4,09 \\
\hline 2 & Asah & 225 & 46,88 & 1,00 & 13,16 & 16,97 & 49,23 & 109,26 \\
\hline 3 & Bakang & 10 & 2,08 & 0,20 & 2,63 & 0,48 & 1,38 & 6,09 \\
\hline 4 & Bune & 5 & 1,04 & 0,20 & 2,63 & 0,14 & 0,40 & 4,08 \\
\hline 5 & Buno bampo & 10 & 2,08 & 0,40 & 5,26 & 0,27 & 0,77 & 8,12 \\
\hline 6 & Ficus & 5 & 1,04 & 0,20 & 2,63 & 0,06 & 0,17 & 3,84 \\
\hline 7 & Ganitri & 20 & 4,17 & 0,40 & 5,26 & 2,33 & 6,77 & 16,20 \\
\hline 8 & Jabon & 15 & 3,13 & 0,20 & 2,63 & 0,64 & 1,86 & 7,62 \\
\hline 9 & Kacunu & 15 & 3,13 & 0,40 & 5,26 & 1,72 & 4,98 & 13,37 \\
\hline 10 & Kampala & 10 & 2,08 & 0,40 & 5,26 & 1,29 & 3,75 & 11,09 \\
\hline 11 & Lama rasikarpa & 5 & 1,04 & 0,20 & 2,63 & 0,25 & 0,74 & 4,41 \\
\hline 12 & Maha & 10 & 2,08 & 0,40 & 5,26 & 1,49 & 4,31 & 11,66 \\
\hline 13 & Nosong & 15 & 3,13 & 0,40 & 5,26 & 2,45 & 7,09 & 15,48 \\
\hline 14 & Nyatoh & 20 & 4,17 & 0,60 & 7,89 & 1,11 & 3,22 & 15,28 \\
\hline 15 & Pakis haji & 10 & 2,08 & 0,40 & 5,26 & 0,16 & 0,47 & 7,82 \\
\hline 16 & Pala hutan & 25 & 5,21 & 0,20 & 2,63 & 0,96 & 2,80 & 10,64 \\
\hline 17 & Pandan & 10 & 2,08 & 0,20 & 2,63 & 0,25 & 0,72 & 5,43 \\
\hline 18 & Rambutan & 10 & 2,08 & 0,20 & 2,63 & 0,10 & 0,28 & 5,00 \\
\hline 19 & Sawo hutan & 5 & 1,04 & 0,20 & 2,63 & 0,11 & 0,31 & 3,99 \\
\hline 20 & Sp 7 & 5 & 1,04 & 0,20 & 2,63 & 0,05 & 0,15 & 3,82 \\
\hline 21 & Sugi manae & 40 & 8,33 & 0,80 & 10,53 & 3,15 & 9,14 & 28,00 \\
\hline \multirow[t]{2}{*}{22} & Tambun-tambun & 5 & 1,04 & 0,20 & 2,63 & 0,36 & 1,04 & 4,72 \\
\hline & Jumlah & 480 & 100,00 & 7,60 & 100,00 & 34,47 & 100,00 & 300,00 \\
\hline
\end{tabular}

Keterangan: $\mathrm{K}=$ Kerapatan; KR = Kerapatan Relatif; F = Frekuensi; FR = Frekuensi Relatif; $\mathrm{D}=\mathrm{Dominansi}$; $\mathrm{DR}=$ Dominansi Relatif; INP = Indek Nilai Penting

Tabel 3.19 menunjukkan pada tingkat semai didominasi oleh jenis asah (INP 88,46 yang dipengaruhi oleh tingginya kerapatan relatif jenis tanaman tersebut yaitu mencapai 14.000 individu/ha. Hal ini menunjukkan bahwa potensi regenerasi jenis asah berdasarkan ketersediaan benih dan viabilitas benih cukup tinggi. Demikian pula pada tingkat sapihan masih didominasi oleh jenis asah (INP 84,39) yang dipengaruhi oleh kerapatan relatif jenis yang tinggi dibandingkan frekuensi. Hal ini menunjukkan bahwa kemampuan asah untuk berkembang di bawah tegakan tergolong baik sehingga sampai tingkat sapihan kerapatannya masih tinggi (1.920 individu/ha).

Pada tingkat pancang jenis yang mendominasi adalah nato (Magnolia lilliifera) dengan nilai INP 98,0 yang dipengaruhi oleh tingkat dominansinya yang tinggi dibandingkan jenis lainnya (D $0,57 \mathrm{~m}^{2} / \mathrm{ha}$ ). Jenis nato dijumpai keberadaannya dari tingkat sapihan dengan nilai frekuensi sebaran cukup tinggi. 

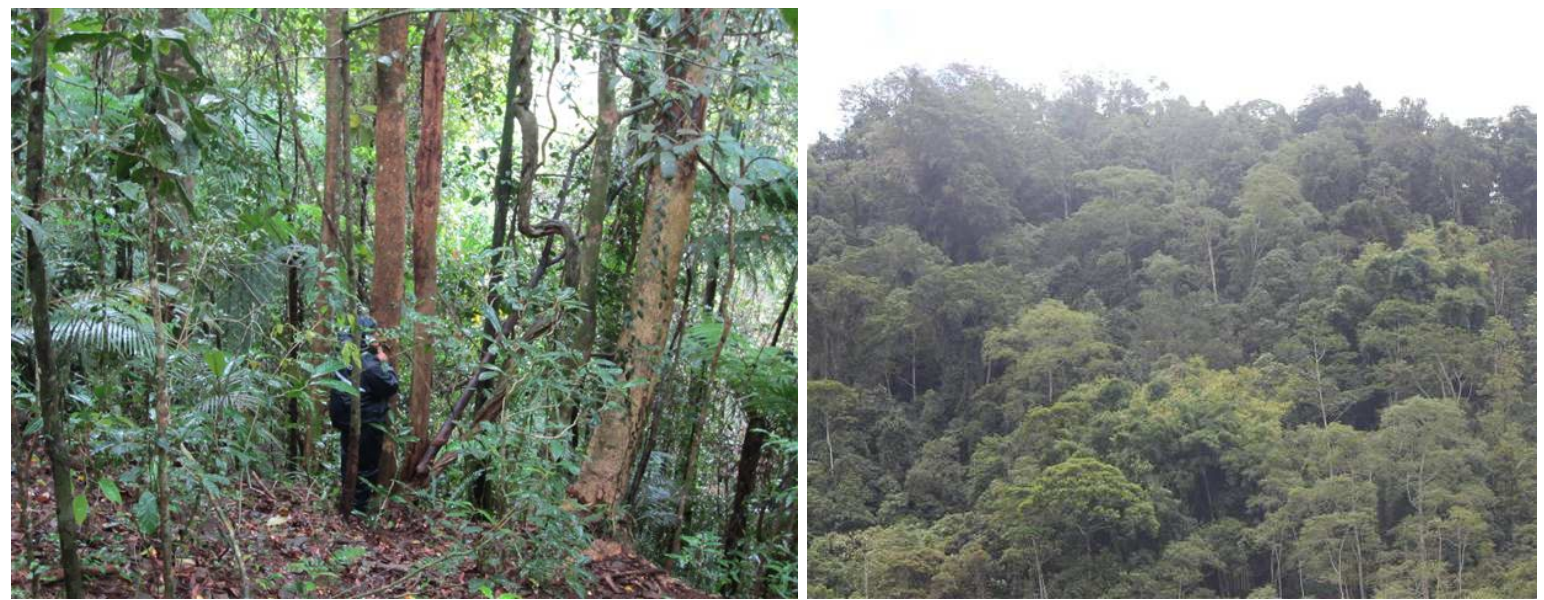

Gambar 3.10 Vegetasi hutan primer di wilayah hulu DAS Balangtieng

Jenis asah kembali mendominasi tingkat pertumbuhan pohon (INP 109,26) yang dipengaruhi oleh nilai kerapatannya yang tinggi (225 individu/ha) dan nilai dominansi $\left(16,97 \mathrm{~m}^{2} / \mathrm{ha}\right)$. Dominasi asah cukup besar dibandingkan jenis lainnya termasuk struktur pertumbuhannya yang normal menjadikan jenis tersebut menjadi jenis penting di hutan alam dataran tinggi sekitar DAS Balangtieng.

\subsection{Keragaman jenis tumbuhan di DAS Balangtieng}

Salah satu fungsi agroforestri adalah menjamin berlangsungnya peran ekologi berupa keanekaragaman hayati baik tumbuhan, satwa maupun mikroorganisme di lahan milik (Jose 2012). Tingkat keanekaragaman hayati tumbuhan berhabitus pohon yang dikembangkan melalui agroforestry di sekitar DAS Balangtieng berbeda-beda bergantung pada SPL (Gambar 3.11).

Sistem kebun campuran memiliki tingkat keanekaragaman hayati tertinggi di wilayah lahan milik masyarakat dibandingkan SPL lainnya. Sementara itu pada SPL lainnya termasuk kategori rendah dengan nilai H’ beragam baik pada setiap tingkat pertumbuhan maupun antar SPL.

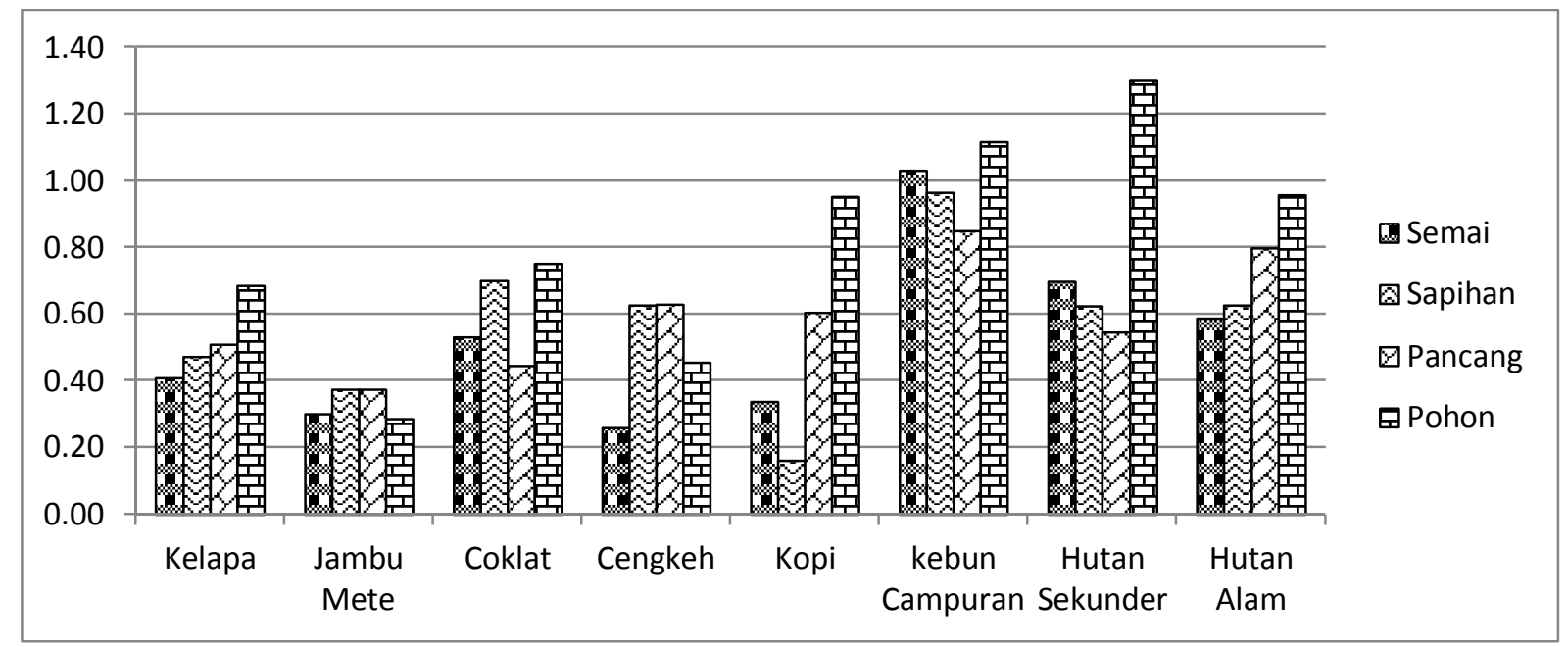

Gambar 3.11 Nilai keragaman hayati tumbuhan pada setiap SPL di sekitar DAS Balangtieng, Kabupaten Bulukumba 
Keanekaragaman jenis tumbuhan hutan sekunder pada tingkat pertumbuhan pohon tergolong sedang $\left(H^{\prime}=1,3\right)$ sedangkan pada tingkat semai hingga pancang tergolong rendah. Sementara itu keanekaragaman jenis tumbuhan pepohonan di hutan alam dataran tinggi tergolong rendah nilai indeks H' (H' 0,96). Rendahnya keanekaragaman jenis tumbuhan pepohonan di hutan alam kemungkinan disebabkan kurangnya jumlah plot yang representatif hutan alam. Meskipun demikian komposisi jenis tumbuhan di hutan alam menunjukkan jenis yang berbeda dengan hutan sekunder dan SPL di lahan milik (Tabel 3.19). Disamping itu keanekaragaman jenis tumbuhan di lahan milik sebagian besar tersusun atas jenis-jenis pohon budidaya khususnya buah-buahan dan sangat sedikit kehadiran jenis kayu hutan alam.

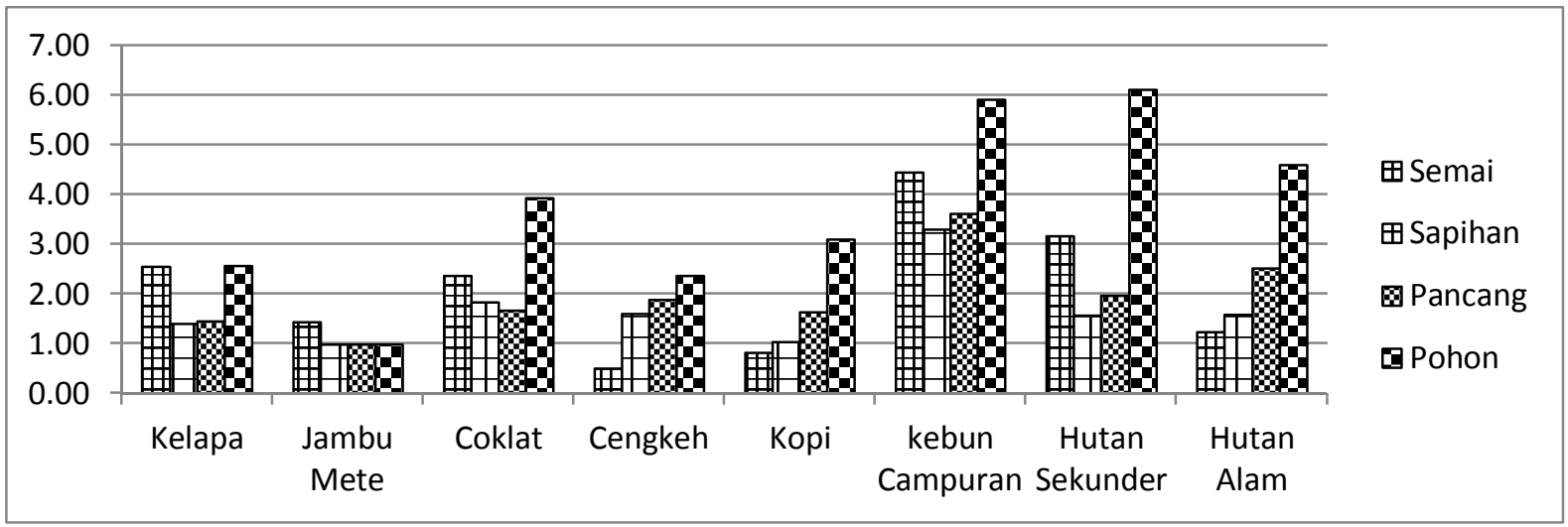

Gambar 3.12 Nilai kekayaan jenis tumbuhan pada setiap SPL di sekitar DAS Balangtieng, Kabupaten Bulukumba

\subsection{Kekayaan jenis tumbuhan di DAS Balangtieng}

Sementara itu berdasarkan tingkat kekayaan jenis tumbuhan, secara umum agroforestry kebun campuran menunjukkan tingkat kekayaan jenis yang sedang hampir pada semua tingkat pertumbuhan meskipun pada tingkat pohon nilai indeks R' hutan sekunder lebih tinggi (Gambar 3.12). Hal ini menunjukkan bahwa sebaran keberagaman jenis tumbuhan pada agroforestry kebun campuran cukup baik sehingga bukan hanya nilai keanekaragaman hayatinya saja yang lebih tinggi dibandingkan SPL lainnya di lahan milik melainkan pada tingkat kekayaan jenisnya pun tidak didominasi oleh jenis tertentu dengan dominasi yang tinggi.

Secara umum Gambar 3.110 dan 3.12 menunjukkan agroforestry kebun campuran merupakan kantung keanekaragaman hayati tumbuhan di lahan milik yang ditunjukkan dengan nilai indek H' dan R' lebih tinggi dibandingkan SPL lainnya termasuk hutan sekunder bahkan pada tingkat pertumbuhan semai dan pohon tergolong sedang. Agroforestry kebun campuran mewakili agroforestry dengan pengelolaan yang tidak intensif. Hal ini pun menunjukkan bahwa keberadaan kebun campuran yang dikembangkan oleh masyarakat penting untuk dijaga sebagai kearifan lokal dalam konservasi 
keanekaragaman hayati di lahan milik meskipun jenis penyusunnya tidak mewakili jenis-jenis yang ada di hutan alam.

Sementara itu untuk keanekaragaman jenis tumbuhan pada agroforestry yang dikelola secara intensif seperti SPL kelapa, jambu mete, coklat, cengkeh dan kopi tergolong rendah dengan tingkat keanekaragaman hayati dan keyaan jenis tertinggi dijumpai pada agroforestry kopi dan coklat. Jenis tumbuhan pada pola agroforestry kopi dan coklat lebih banyak dibandingkan pola intensif lainnya. Selain itu kedua pola agroforestry tersebut memerlukan pohon penaung agar kopi dan coklat tumbuh dengan hasil optimal. Adanya keberagaman jenis tumbuhan yang berfungsi sebagai penaung pada pola agroforestry kopi dan coklat dapat menjadi jembatan bagi kepentingan kelestarian jenis tumbuhan pada lahan milik sekaligus mengurangi diskursus antara kepentingan ekonomi dan ekologi sebagaimana menurut Clough et al (2011).

Adanya fenomena perbedaan tingkat keanekaragaman hayati antar pola agroforestri menunjukkan adanya pengaruh tingkat pengelolaan terhadap tingkat keanekaragaman hayati. Hal senada dilaporkan pula oleh De Beenhouwer et al (2013) bahwa hasil meta analisis menunjukkan terjadinya penurunan keanekaragaman hayati ketika hutan di Afrika, Amerika Latin dan Asia dirubah menjadi agroforestry coklat dan kopi.

Peningkatan komponen penyusun tumbuhan pada agroforestry intensif dapat meningkatkan keanekaragaman hayati organisme lain seperti invertebrata (Moço et al 2010), serangga (Stamps and Linit 1997) dan mikroorganisme (Unger et al 2013).. Adapun upaya penambahan jenis tumbuhan lain pada pola agroforestsri intensif adalah pada posisi pagar batas lahan seperti pada pola agroforestry kelapa, jambu meta dan cengkeh serta pada posisi sebagai penaung pada pola agroforestry coklat dan kopi. Kondisi tersebut dapat menjadi kearifan lokal baru selain kebun campuran tidak intensif dalam menjaga keanekaragaman hayati tetap terakomodir pada pola SPL yang intensif.

\subsection{Kemiripan jenis tumbuhan antar SPL di DAS Balangtieng}

Sementara itu distribusi jenis-jenis tumbuhan yang menjadi penyusun SPL dari hulu sampai hilir memiliki tingkat kesamaan jenis dengan pendekatan Indeks Sorrensen sebagaimana Tabel 3.20 - 3.23. Sebagian besar jenis tumbuhan tidak tersebar pada berbagai SPL yang ditunjukkan oleh nilai indeks kesamaan sorrensen $\left(\mathrm{C}_{\mathrm{N}}\right)<1$. Semakin mendekati nilai 1 maka semakin besar tingkat kesamaan jenis antar SPL tersebut. 
Tabel 3.20 Nilai indeks kesamaan jenis Sorrensen tingkat semai pada beberapa SPL di sekitar DAS Balangtieng, Kabupaten Bulukumba

\begin{tabular}{l|cccccccc}
\hline SPL & Kelapa & Coklat & Cengkeh & $\begin{array}{c}\text { Mambu } \\
\text { Mete }\end{array}$ & Kopi & KC & HS & HA \\
Kelapa & 0,000 & & & & & & & \\
Coklat & 0,025 & 0,000 & & & & & & \\
Cengkeh & 0,000 & 0,024 & 0,000 & & & & & \\
Mete & 0,012 & 0,025 & 0,000 & 0,000 & & & & \\
Kopi & 0,000 & 0,318 & 0,089 & 0,000 & 0,000 & & & \\
KC & 0,036 & 0,294 & 0,023 & 0,012 & 0,29 & 0,000 & & \\
HS & 0,048 & 0,512 & 0,013 & 0,007 & 0,182 & 0,299 & 0,000 & \\
HA & 0,000 & 0,038 & 0,063 & 0,000 & 0,085 & 0,036 & 0,023 & 0,000 \\
\hline
\end{tabular}

Keterangan: $\mathrm{JM}=$ Jambu mete; $\mathrm{KC}=$ Kebun Campuran; HS = Hutan Sekunder; HA = Hutan Alam

Tabel 3.20 menunjukkan pada tingkat semai SPL Coklat lebih memiliki tingkat kesamaan jenis dengan SPL hutan sekunder $\left(C_{N} 0,512\right)$ atau sebanyak $51,2 \%$ terdapat jenis tumbuhan yang sama. Beberapa jenis tumbuhan tingkat semai yang dijumpai pada kedua lokasi tersebut antara lain kopi, langsat, petai, pulai dan rambutan. Sementara itu jenis semai pada SPL kelapa termasuk paling banyak memiliki perbedaan dengan SPL lainnya yang ditunjukkan dengan nilai $\mathrm{C}_{\mathrm{N}}=0$ seperti berbeda dengan SPL Cengkeh, Kopi dan Hutan Alam.

Tabel 3.21 Nilai indeks kesamaan jenis Sorrensen tingkat sapihan pada beberapa SPL di sekitar DAS Balangtieng, Kabupaten Bulukumba

\begin{tabular}{l|cccccccc}
\hline SPL & Kelapa & Coklat & Cengkeh & JM & Kopi & KC & HS & HA \\
\hline Kelapa & 0,000 & & & & & & & \\
Coklat & 0,000 & 0,000 & & & & & & \\
Cengkeh & 0,000 & 0,421 & 0,000 & & & & & \\
JM & 0,000 & 0,000 & 0,000 & 0,000 & & & & \\
Kopi & 0,015 & 0,068 & 0,061 & 0,000 & 0,000 & & & \\
KC & 0,162 & 0,217 & 0,188 & 0,000 & 0,043 & 0,000 & & \\
HS & 0,000 & 0,310 & 0,351 & 0,000 & 0,291 & 0,185 & 0,000 & 0,000 \\
\hline HA & 0,000 & 0,116 & 0,145 & 0,000 & 0,049 & 0,000 & 0,136 & 0,000 \\
\hline
\end{tabular}

Keterangan: JM = Jambu mete; $\mathrm{KC}=$ Kebun Campuran; HS = Hutan Sekunder; HA = Hutan Alam

Tabel 3.21 menunjukkan pada tingkat pertumbuhan sapihan sebagian besar diantara SPL agroforestry tidak memiliki kesamaan yang ditunjukkan dengan nilai indeks sorrensen dibawah 0,5 hingga 0,0 atau tidak ada jenis tumbuhan yang sama seperti antara SPL kelapa dengan SPL coklat, cengkeh, mete, hutan sekunder dan hutan alam. Meskipun demikian nilai kesamaan jenis antara SPL coklat dan cengkeh termasuk paling besar disbanding lainnya yaitu $C_{N} 0,421$. Adapun beberapa jenis sapihan yang dijumpai pada kedua SPL tersebut antara lain cengkeh, kopi dan gmelina. 
Tabel 3.22 Nilai indeks kesamaan jenis Sorrensen tingkat pancang pada beberapa SPL di sekitar DAS Balangtieng, Kabupaten Bulukumba

\begin{tabular}{l|cccccccc}
\hline SPL & Kelapa & Coklat & Cengkeh & JM & Kopi & KC & HS & HA \\
\hline Kelapa & $0,, 000$ & & & & & & & \\
Coklat & 0,412 & 0,000 & & & & & & \\
Cengkeh & 0,040 & 0,191 & 0,000 & & & & & \\
JM & 0,073 & 0,000 & 0,000 & 0,000 & & & & \\
Kopi & 0,105 & 0,198 & 0,174 & 0,000 & 0,000 & & & \\
KC & 0,564 & 0,531 & 0,274 & 0,061 & 0,13 & 0,000 & & \\
HS & 0,062 & 0,149 & 0,388 & 0,000 & 0,251 & 0,163 & 0,000 & 0,000 \\
HA & 0,000 & 0,024 & 0,023 & 0,000 & 0,033 & 0,032 & 0,011 & \\
\hline
\end{tabular}

Keterangan : JM = Jambu mete; $\mathrm{KC}=$ Kebun Campuran; HS = Hutan Sekunder; HA = Hutan Alam

Tabel 3.22 menunjukkan pada tingkat pancang terdapat beberapa SPL dengan nilai $\mathrm{C}_{\mathrm{N}}$ diatas $50 \%$ yaitu antara SPL kelapa dan coklat dengan kebun campuran dengan nilai $\mathrm{C}_{\mathrm{N}}$ masing-masing antara lain 0,564 dan 0,531. Jenis tumbuhan yang dijumpai pada SPL kelapa dan kebun campuran adalah coklat dan mete sedangkan Adapun beberapa jenis tumbuhan yang dijumpai pada ketiga SPL tersebut adalah coklat, sedangkan jenis lainnya hanya dijumpai diantara masing-masing kedua SPL.

Tabel 3.23 Nilai indeks kesamaan jenis Sorrensen tingkat pohon pada beberapa SPL di sekitar DAS Balangtieng, Kabupaten Bulukumba

\begin{tabular}{l|cccccccc}
\hline SPL & Kelapa & Coklat & Cengkeh & JM & Kopi & KC & HS & HA \\
\hline Kelapa & 0,000 & & & & & & & \\
Coklat & 0,040 & 0,000 & & & & & & \\
Cengkeh & 0,023 & 0,177 & 0,000 & & & & & \\
JM & 0,442 & 0,025 & 0,010 & 0,000 & & & & \\
Kopi & 0,000 & 0,173 & 0,138 & 0,010 & 0,000 & & & \\
KC & 0,22 & 0,235 & 0,256 & 0,167 & 0,138 & 0,000 & & \\
HS & 0,030 & 0,278 & 0,138 & 0,028 & 0,265 & 0,208 & 0,000 & 0,000 \\
\hline HA & 0,007 & 0,012 & 0,000 & 0,000 & 0,000 & 0,015 & 0,123 & 0 \\
\hline
\end{tabular}

Keterangan: JM = Jambu mete; $\mathrm{KC}=$ Kebun Campuran; HS = Hutan Sekunder; HA = Hutan Alam

Tabel 3.23 menunjukkan pada tingkat pohon tidak terdapat kesamaan jenis yang menonjol antar SPL dengan nilai indeks kesamaan jenis tertinggi adalah antara SPL kelapa dengan jambu mete $\left(C_{N} 0,442\right)$. terdapat beberapa jenis pohon yang banyak hadir pada beberapa SPL antara lain Biti (Vitex coppasus), coklat dan langsat. Jenis biti dan coklat menyebar di 6 buah SPL (tabel 3.24). Hal ini menunjukkan bahwa kedua jenis tersebut memiliki nilai penting bagi masyarakat di sekitar DAS Balangtieng dari hulu hingga hilir. Jenis biti merupakan jenis kayu hutan alam yang menjadi bahan baku utama pembuatan perahu pinisi dan menjadi flora penting bagi Kabupaten Bulukumba, sedangkan coklat menjadi komoditi perkebunan yang bernilai ekonomi cukup menjanjikan bagi masyarakat sehingga banyak ditanam di kebun-kebun masyarakat. Adapun jenis lainnya yang banyak menyebar di berbagai 
SPL adalah jenis buah-buahan seperti langsat, durian, nangka, mangga, rambutan, jambu mete dan petai serta jenis perenial crop seperti kopi dan kelapa. Selain jenis penghasil buah-buahan terdapat pula jenis pohon penghasil kayu pertukangan yang banyak ditanam masyarakat pada berbagai pola SPL meliputi gmelina dan sengon.

Tabel 3.24 Sebaran kerapatan mutlak jenis pohon pada beberapa SPL di sekitar DAS Balangtieng, Kabupaten Bulukumba

\begin{tabular}{|c|c|c|c|c|c|c|c|c|c|}
\hline No & Jenis & Kelapa & Coklat & Cengkeh & JM & Kopi & $\mathrm{KC}$ & $\mathrm{HS}$ & $\mathrm{HA}$ \\
\hline 1 & Afrika & 0 & 0 & 0 & 0 & 0 & 1 & 0 & 0 \\
\hline 2 & Ahu-Ahu & 0 & 0 & 0 & 0 & 0 & 0 & 0 & 1 \\
\hline 3 & Alpukat & 0 & 0 & 0 & 0 & 0 & 0 & 1 & 0 \\
\hline 4 & Angsana & 0 & 0 & 0 & 0 & 0 & 1 & 0 & 0 \\
\hline 5 & Aren & 0 & 0 & 0 & 0 & 1 & 0 & 0 & 0 \\
\hline 6 & Artocarpus Sp. & 1 & 0 & 0 & 0 & 0 & 0 & 0 & 0 \\
\hline 7 & Asah & 0 & 0 & 0 & 0 & 0 & 0 & 11 & 45 \\
\hline 8 & Asam Jawa & 1 & 0 & 0 & 0 & 0 & 0 & 0 & 0 \\
\hline 9 & Bakang Kampung & 0 & 0 & 0 & 0 & 3 & 0 & 0 & 0 \\
\hline 10 & Bakang & 0 & 0 & 0 & 0 & 0 & 0 & 0 & 2 \\
\hline 11 & Bisuhu & 0 & 0 & 0 & 0 & 0 & 0 & 2 & 0 \\
\hline 12 & Biti & 1 & 1 & 2 & 1 & 0 & 2 & 2 & 0 \\
\hline 13 & Bune & 1 & 0 & 0 & 0 & 0 & 0 & 0 & 1 \\
\hline 14 & Buno Bampo & 0 & 0 & 0 & 0 & 0 & 0 & 0 & 2 \\
\hline 15 & Buto & 0 & 0 & 0 & 0 & 0 & 0 & 1 & 0 \\
\hline 16 & Cengkeh & 0 & 0 & 179 & 0 & 0 & 33 & 1 & 0 \\
\hline 17 & Coklat & 0 & 148 & 1 & 1 & 2 & 18 & 9 & 0 \\
\hline 18 & Dadap & 0 & 4 & 1 & 0 & 5 & 0 & 7 & 0 \\
\hline 19 & Donri & 0 & 0 & 0 & 0 & 2 & 0 & 0 & 0 \\
\hline 20 & Durian & 0 & 4 & 7 & 0 & 0 & 1 & 4 & 0 \\
\hline 21 & Duwet & 1 & 0 & 0 & 0 & 0 & 0 & 0 & 0 \\
\hline 22 & Ficus Sp. & 0 & 0 & 0 & 0 & 0 & 0 & 0 & 1 \\
\hline 23 & Gamal & 0 & 41 & 26 & 0 & 0 & 0 & 7 & 0 \\
\hline 24 & Ganitri & 0 & 0 & 0 & 0 & 0 & 0 & 0 & 0 \\
\hline 25 & Gempol & 2 & 0 & 0 & 0 & 0 & 0 & 0 & 0 \\
\hline 26 & Gmelina & 0 & 7 & 1 & 0 & 0 & 2 & 0 & 0 \\
\hline 27 & Pansor & 0 & 0 & 0 & 0 & 0 & 0 & 0 & 3 \\
\hline 28 & Jambu & 0 & 1 & 0 & 0 & 0 & 0 & 0 & 0 \\
\hline 29 & Jambu Air & 1 & 0 & 0 & 0 & 0 & 0 & 0 & 0 \\
\hline 30 & Jambu Bol & 0 & 0 & 0 & 0 & 0 & 2 & 0 & 0 \\
\hline 31 & Jati & 0 & 1 & 0 & 1 & 0 & 0 & 0 & 0 \\
\hline 32 & Jeruk & 0 & 0 & 0 & 1 & 0 & 0 & 0 & 0 \\
\hline 33 & Jeruk Bali & 0 & 3 & 0 & 0 & 0 & 0 & 0 & 0 \\
\hline 34 & Kacunu & 0 & 0 & 0 & 0 & 0 & 0 & 0 & 3 \\
\hline 35 & Kampala & 0 & 0 & 0 & 0 & 0 & 0 & 0 & 2 \\
\hline 36 & Karet & 0 & 1 & 0 & 0 & 0 & 0 & 0 & 0 \\
\hline 37 & Kayu Cina & 0 & 0 & 3 & 0 & 0 & 4 & 0 & 0 \\
\hline
\end{tabular}




\begin{tabular}{|c|c|c|c|c|c|c|c|c|c|}
\hline No & Jenis & Kelapa & Coklat & Cengkeh & $\mathrm{JM}$ & Kopi & $\mathrm{KC}$ & HS & $\mathrm{HA}$ \\
\hline 38 & Kayu Manis & 0 & 0 & 0 & 0 & 1 & 0 & 0 & 0 \\
\hline 39 & Kelapa & 114 & 0 & 0 & 31 & 0 & 25 & 0 & 0 \\
\hline 40 & Kenanga & 0 & 0 & 0 & 0 & 0 & 1 & 0 & 0 \\
\hline 41 & Kenari & 5 & 0 & 0 & 0 & 0 & 0 & 0 & 0 \\
\hline 42 & Kopi & 0 & 3 & 1 & 0 & 2 & 1 & 10 & 0 \\
\hline 43 & Lama Rasikarpa & 0 & 0 & 0 & 0 & 0 & 0 & 0 & 1 \\
\hline 44 & Lamtoro & 0 & 1 & 0 & 0 & 0 & 0 & 0 & 0 \\
\hline 45 & Langsat & 0 & 12 & 3 & 0 & 12 & 32 & 5 & 0 \\
\hline 46 & Laniki & 0 & 0 & 0 & 0 & 0 & 0 & 1 & 0 \\
\hline 47 & Maha & 0 & 0 & 0 & 0 & 0 & 0 & 0 & 2 \\
\hline 48 & Mahoni & 0 & 0 & 0 & 0 & 0 & 0 & 7 & 0 \\
\hline 49 & Mangga & 12 & 2 & 0 & 0 & 0 & 6 & 2 & 0 \\
\hline 50 & Mangga Macan & 1 & 0 & 0 & 0 & 0 & 1 & 0 & 0 \\
\hline 51 & Matoa & 0 & 0 & 0 & 0 & 0 & 1 & 0 & 0 \\
\hline 52 & Mete & 46 & 2 & 0 & 117 & 0 & 0 & 2 & 0 \\
\hline 53 & Mojo & 0 & 2 & 1 & 0 & 0 & 0 & 0 & 0 \\
\hline 54 & Nangka & 8 & 2 & 4 & 0 & 0 & 9 & 0 & 0 \\
\hline 55 & Nosong & 0 & 0 & 0 & 0 & 0 & 0 & 0 & 3 \\
\hline 56 & Natoh & 0 & 0 & 0 & 0 & 0 & 0 & 0 & 4 \\
\hline 57 & Pakis Haji & 0 & 0 & 0 & 0 & 0 & 0 & 0 & 2 \\
\hline 58 & Pala Hutan & 0 & 0 & 0 & 0 & 0 & 0 & 0 & 5 \\
\hline 59 & Pandan & 0 & 0 & 0 & 0 & 0 & 0 & 1 & 2 \\
\hline 60 & Petai & 0 & 7 & 4 & 0 & 0 & 7 & 7 & 0 \\
\hline 61 & Picung & 0 & 0 & 0 & 0 & 0 & 0 & 1 & 0 \\
\hline 62 & Pipturus Sp. & 0 & 0 & 0 & 0 & 2 & 0 & 0 & 0 \\
\hline 63 & Pulai & 0 & 0 & 1 & 0 & 0 & 0 & 5 & 0 \\
\hline 64 & Rambutan & 0 & 4 & 0 & 0 & 0 & 24 & 4 & 2 \\
\hline 65 & Rambutan Hutan & 0 & 0 & 0 & 0 & 0 & 0 & 13 & 0 \\
\hline 66 & Randu & 0 & 0 & 0 & 0 & 0 & 0 & 3 & 0 \\
\hline 67 & Rao & 0 & 0 & 0 & 0 & 0 & 0 & 1 & 0 \\
\hline 68 & Sawo Hutan & 0 & 0 & 0 & 0 & 0 & 0 & 0 & 1 \\
\hline 69 & Sengon & 0 & 6 & 0 & 0 & 10 & 0 & 22 & 0 \\
\hline 70 & Sp1 & 0 & 0 & 0 & 0 & 0 & 0 & 0 & 1 \\
\hline 71 & Sp3 & 0 & 0 & 1 & 0 & 0 & 0 & 1 & 0 \\
\hline 72 & Sp4 & 0 & 0 & 0 & 0 & 0 & 0 & 1 & 0 \\
\hline 73 & Sp5 & 0 & 0 & 0 & 0 & 0 & 0 & 2 & 0 \\
\hline 74 & Spatodea & 0 & 0 & 0 & 0 & 0 & 1 & 0 & 0 \\
\hline 75 & Sugi Manae & 0 & 0 & 0 & 0 & 0 & 0 & 0 & 8 \\
\hline 76 & Sukun & 7 & 2 & 0 & 0 & 0 & 0 & 0 & 0 \\
\hline 77 & Sunging/Dilenia & 0 & 0 & 0 & 0 & 0 & 0 & 2 & 0 \\
\hline 78 & Suren & 0 & 0 & 7 & 0 & 6 & 0 & 0 & 0 \\
\hline 79 & Tambun-Tambun & 0 & 0 & 0 & 0 & 0 & 0 & 0 & 1 \\
\hline 80 & Tera(Ficus) & 0 & 0 & 0 & 0 & 0 & 0 & 0 & 0 \\
\hline \multicolumn{2}{|c|}{ Jumlah Individu (N) } & 201 & 254 & 242 & 152 & 46 & 172 & 135 & 92 \\
\hline \multicolumn{2}{|c|}{ Jumlah Jenis (S) } & 14 & 21 & 16 & 6 & 11 & 20 & 29 & 21 \\
\hline
\end{tabular}

Keterangan: $\mathrm{JM}=$ Jambu mete; $\mathrm{KC}=$ Kebun Campuran; HS = Hutan Sekunder; HA = Hutan Alam 


\subsection{Etnobotani}

Pemanfaatan jenis tumbuhan pada wilayah DAS Balangtieng dikelompokkan menjadi pemanfaatan untuk pangan, obat-obatan, bahan bangunan, peralatan rumah tangga, kayu bakar dan penggunaan yang berkaitan dengan budaya. Tabel 3.25 menunjukkan terdapat 53 jenis pohon yang dimanfaatkan oleh masyarakat wilayah DAS Balangtieng. Jenis-jenis tersebut termasuk dalam 29 famili serta beberapa jenis yang belum teridentifikasi nama ilmiah dan familinya (Gambar 3.13). Famili fabaceae menunjukkan jumlah jenis terbanyak (6 jenis) yaitu dadap, gamal, jengkol, johar, petai dan sengon. Famili berikutnya yang menujukkan jumlah jenis terbanyak adalah arecaceae (4 jenis). Jenis-jenis pada famili yang dikenal memiliki banyak manfaat ini antara lain kelapa, aren, pinang dan sagu.

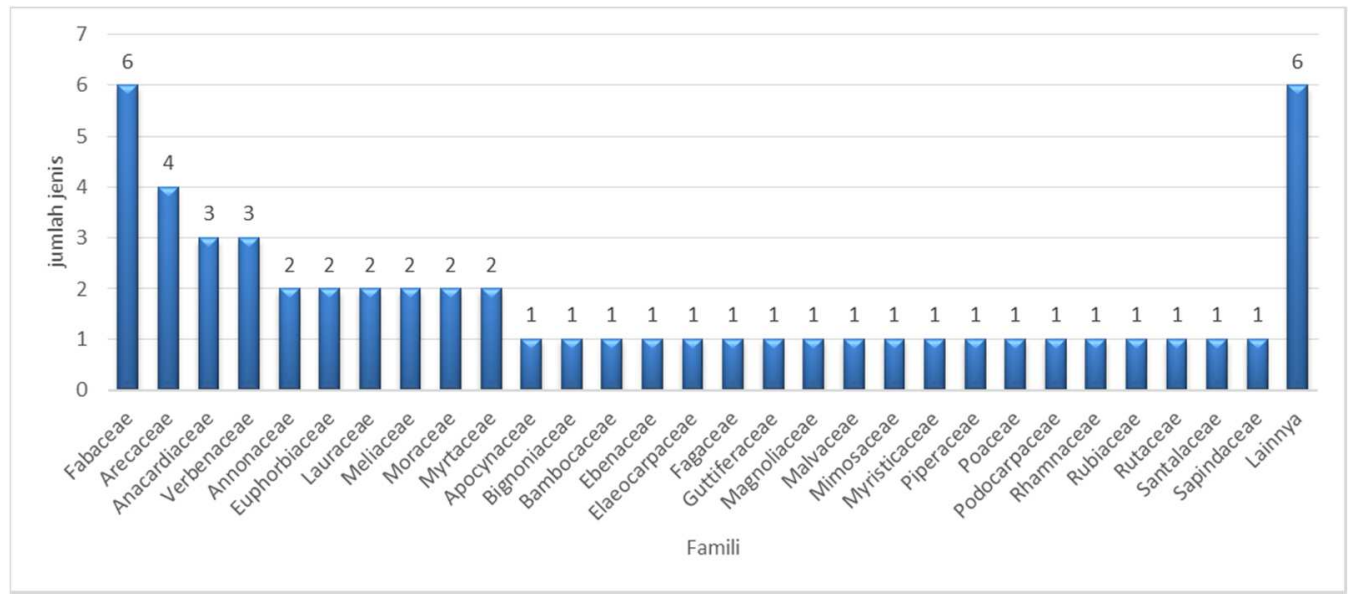

Gambar 3.13 Jumlah jenis pohon berdasarkan kelompok famili

Berdasarkan kelompok pemanfaatannya, Gambar 3.14 menunjukkan bahwa masyarakat menggunakan jenis pohon paling beragam untuk bahan bangunan, disusul untuk pangan, obat-obatan, kayu bakar, peralatan rumah tangga dan budaya. Hal ini menunjukkan bahwa keanekaragaman jenis pohon yang ada di wilayah DAS Balangtieng ini memiliki nilai penting bagi masyarakat dalam mendukung pemenuhan kebutuhan papan, pangan, obat-obatan, sumber energi dan kebudayaan.

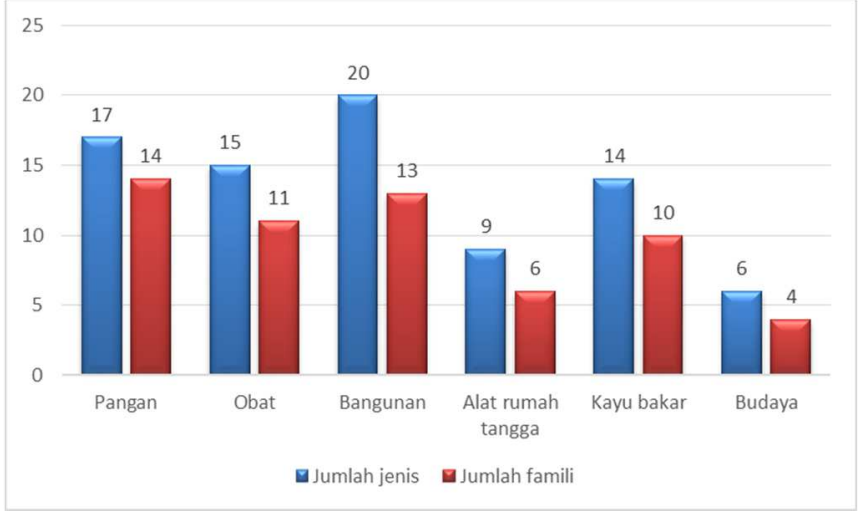

Gambar 3.14 Jumlah jenis dan famili pohon yang dimanfaatkan masyarakat 
Berdasarkan jumlah responden yang memanfaatkan tiap jenis, rambutan adalah jenis yang paling banyak dimanfaatkan oleh responden (Gambar 3.15). Jenis-jenis lain yang dimanfaatkan lebih dari 15 responden adalah, sengon, langsat, durian, nangka dan kopi. Jenis-jenis yang paling banyak dimanfaatkan tersebut cenderung jenis penghasil buah-buahan, kecuali sengon yang merupakan jenis penghasil kayu pertukangan. Sementara itu, lebih dari setengah jenis-jenis lainnya (tepatnya 37 jenis) dimanfaatkan oleh masyarakat dalam skala terbatas oleh kurang dari 5 orang responden.

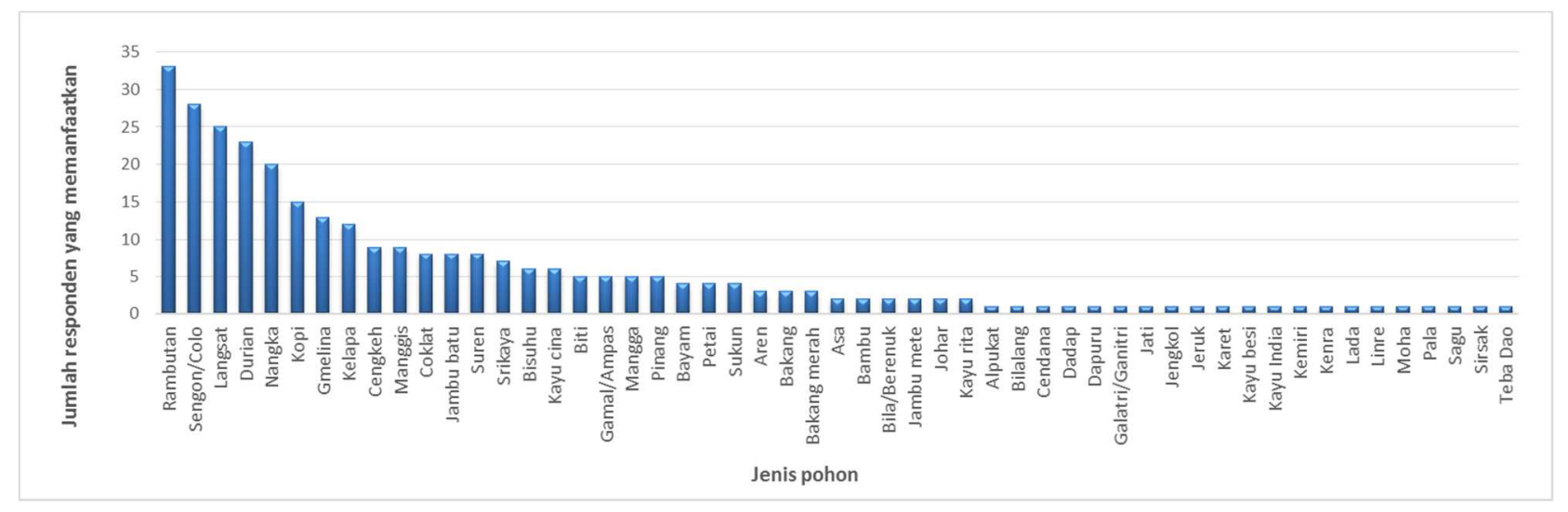

Gambar 3.15 Jenis pohon berdasarkan jumlah responden yang memanfaatkan

Beberapa jenis pohon digunakan masyarakat lebih dari satu manfaat (Tabel 3.25). Jenis pohon yang dimanfaatkan oleh masyarakat dalam 3 kelompok manfaat antara lain kelapa, kopi, nangka, rambutan, biti dan gmelina. Selain jenis pemanfaatan yang beragam, bagian pohon yang dimanfaatkan dari jenisjenis tersebut juga beragam. Kelapa misalnya, bagian batang jenis ini dimanfaatkan oleh masyarakat sebagai bahan bangunan, buahnya sebagai bahan makanan dan daunnya sebagai bagian dari ornamen pada pesta pernikahan (budaya). Tanaman kopi yang cukup banyak di daerah hulu dan tengah, selain buahnya dimanfaatkan untuk pangan, masyarakat juga memanfaatkan daunnya sebagai obat penurun tekanan darah dan ranting-rantingnya untuk kayu bakar. Demikian juga dengan pohon rambutan, masyarakat tidak hanya memanfaatkan buahnya sebagai pangan, tapi juga batang pohonnya untuk bahan bangunan dan cabang/rantinya untuk kayu bakar.

Masyarakat memanfaatkan jenis-jenis pohon tersebut pada umumnya dari lahan kebunnya sendiri. Namun demikian sebagian masyarakat juga mengambil dari lahan milik orang lain ataupun di kawasan hutan. Pemanfaatan jenis yang diambil bukan dari lahan sendiri biasanya pada jenis pemanfaatan yang dianggap tidak untuk komersil serta tidak mengurangi hak pemilik lahan untuk memanfaatkan pohon itu sendiri. Misalnya pada pemanfaatan kayu bakar, masyarakat seringkali hanya mengambil cabang tau ranting-ranting yang jatuh. Demikian juga dengan pemanfaatan jenis yang hanya mengambil daun atau kulit dan getah untuk obat-obatan, masyarakat menganggap pemanfaatan jenis ini bersifat mendesak dan tidak juga merugikan kelangsungan hidup pohon. Hal ini menunjukkan bahwa keragaman jenis pohon pada lahan milik maupun kawasan hutan dalam hal tertentu merupakan aset bersama yang dapat dimanfaatkan masyarakat tanpa merugikan pemilik lahan. 
Tabel 3.25 Pemanfaatan jenis pohon oleh masyarakat di wilayah DAS Balangtieng

\begin{tabular}{|c|c|c|c|c|c|c|}
\hline \multicolumn{3}{|c|}{ Jenis } & \multirow{2}{*}{$\begin{array}{c}\text { Lokasi } \\
\text { pengambilan }\end{array}$} & \multirow{2}{*}{$\begin{array}{c}\text { Jenis } \\
\text { pemanfaatan }\end{array}$} & \multirow{2}{*}{$\begin{array}{l}\text { Bagian yang } \\
\text { dimanfaatkan }\end{array}$} & \multirow{2}{*}{$\begin{array}{c}\text { Tujuan } \\
\text { pemanfaatan }\end{array}$} \\
\hline Nama lokal & Nama ilmiah & Famili & & & & \\
\hline Alpukat & Persea americana Mill. & Lauraceae & $\mathrm{KS}, \mathrm{KO}$ & $\mathrm{O}$ & $\mathrm{D}$ & $\mathrm{Kn}$ \\
\hline Aren & Arenga pinata Wurmb. Merr. & Arecaceae & KS & Rt & $\mathrm{Bt}$ & $\mathrm{Kn}$ \\
\hline Asa & Castanopsis acuminatassima A.Dc & Fagaceae & $\mathrm{H}$ & $\mathrm{Bg}$ & $\mathrm{Bt}$ & $\mathrm{Kn}$ \\
\hline Bakang & Litsea elliptica Blume & Lauraceae & $\mathrm{KS}, \mathrm{H}$ & $\mathrm{Bg}, \mathrm{Rt}$ & $\mathrm{Bt}, \mathrm{Cb}$ & $\mathrm{Kn}$ \\
\hline Bakang merah & & & $\mathrm{KS}, \mathrm{H}$ & $\mathrm{Bg}$ & $\mathrm{Bt}$ & $\mathrm{Kn}$ \\
\hline Bambu & Bambusa sp. & Poaceae & KS & $\mathrm{Rt}, \mathrm{Bd}$ & $\mathrm{Bt}$ & $\mathrm{Kn}$ \\
\hline Bayam/Bayam jawa & Maesopsis eminii Engl. & Rhamnaceae & KS, H & $\mathrm{Bg}, \mathrm{KB}$ & $\mathrm{Bt}, \mathrm{Cb}$ & $\mathrm{Kn}$ \\
\hline Bila/Berenuk & Crescentia cujete & Bignoniaceae & $\mathrm{KS}, \mathrm{KO}$ & $\mathrm{O}$ & $\mathrm{D}$ & $\mathrm{Kn}$ \\
\hline Bilalang & Albizzia procera Benth & Mimosaceae & KS & $\mathrm{Bg}$ & $\mathrm{Bt}$ & $\mathrm{Kn}$ \\
\hline Bisuhu & $\begin{array}{l}\text { Magnolia sumatrana var. glauca (BI.) Figlar } \\
\& \text { Noot }\end{array}$ & Magnoliaceae & $\mathrm{KS}, \mathrm{H}$ & $\mathrm{Bg}, \mathrm{Rt}$ & $\mathrm{Bt}$ & $\mathrm{Kn}$ \\
\hline Biti & Vitex cofassus Reinw. ex Blume & Verbenaceae & $\mathrm{KS}, \mathrm{KO}$ & $\mathrm{Bg}, \mathrm{Rt}, \mathrm{KB}$ & $\mathrm{Bt}, \mathrm{Cb}$ & $\mathrm{Kn}$ \\
\hline Cendana & Santalum album L. & Santalaceae & KO & $\mathrm{Bg}$ & $\mathrm{Bt}$ & $\mathrm{Kn}$ \\
\hline Cengkeh & Syzygium aromaticum $\mathrm{L}$ & Myrtaceae & $\mathrm{KO}, \mathrm{KS}, \mathrm{H}$ & $\mathrm{P}, \mathrm{KB}$ & $\mathrm{Cb}, \mathrm{Bu}$ & $\mathrm{Kn}, \mathrm{Km}$ \\
\hline Coklat & Theobroma cacao L. & Malvaceae & $\mathrm{KO}, \mathrm{KS}, \mathrm{H}$ & $\mathrm{P}, \mathrm{KB}$ & $\mathrm{Cb}, \mathrm{Bu}$ & $\mathrm{Kn}, \mathrm{Km}$ \\
\hline Dadap & Erythrina variegate $\mathrm{L}$ & Fabaceae & KS & $\mathrm{Bg}$ & $\mathrm{Bt}$ & $\mathrm{Kn}$ \\
\hline Dapuru & & & KS & $\mathrm{Bg}$ & $\mathrm{Bt}$ & $\mathrm{Kn}$ \\
\hline Durian & Durio zibethinus Morr. & Bombacaceae & $\mathrm{KS}, \mathrm{KO}, \mathrm{H}$ & $\mathrm{P}, \mathrm{O}$ & $\mathrm{A}, \mathrm{Bu}, \mathrm{KI}$ & $\mathrm{Kn}, \mathrm{Km}$ \\
\hline Galatri/Ganitri & Elaeocarpus ganitrus Roxb. & Elaeocarpaceae & KS & $\mathrm{Bg}$ & $\mathrm{Bt}$ & $\mathrm{Kn}$ \\
\hline Gamal/Ampas & Gliricidia sepium (Jacq.)Kunth ex Walp. & Fabaceae & $\mathrm{KS}, \mathrm{KO}$ & KB & $\mathrm{Cb}$ & $\mathrm{Kn}$ \\
\hline Gmelina & Gmelina arbora Roxb. & Verbenaceae & $\mathrm{KS}, \mathrm{KO}$ & $\mathrm{Bg}, \mathrm{Rt}, \mathrm{Kb}$ & $\mathrm{Bt}, \mathrm{Cb}$ & $\mathrm{Kn}, \mathrm{Km}$ \\
\hline Jambu batu & Psidium guajava L. & Myrtaceae & $\mathrm{KS}, \mathrm{KO}, \mathrm{H}$ & $\mathrm{P}, \mathrm{O}$ & $\mathrm{D}, \mathrm{Bu}$ & $\mathrm{Kn}$ \\
\hline Jambu mete & Anacardium occidentale L. & Anacardiaceae & $\mathrm{KS}, \mathrm{KO}, \mathrm{H}$ & KB & $\mathrm{Cb}$ & $\mathrm{Kn}$ \\
\hline Jati & Tectona grandis L.F. & Verbenaceae & KS & $\mathrm{Bg}$ & $\mathrm{Bt}$ & $\mathrm{Kn}, \mathrm{Km}$ \\
\hline
\end{tabular}




\begin{tabular}{|c|c|c|c|c|c|c|}
\hline \multicolumn{3}{|c|}{ Jenis } & \multirow{2}{*}{$\begin{array}{c}\text { Lokasi } \\
\text { pengambilan }\end{array}$} & \multirow{2}{*}{$\begin{array}{c}\text { Jenis } \\
\text { pemanfaatan }\end{array}$} & \multirow{2}{*}{$\begin{array}{l}\text { Bagian yang } \\
\text { dimanfaatkan }\end{array}$} & \multirow{2}{*}{$\begin{array}{c}\text { Tujuan } \\
\text { pemanfaatan }\end{array}$} \\
\hline Nama lokal & Nama ilmiah & Famili & & & & \\
\hline Jengkol & Pithecolobium lobatum Benth & Fabaceae & KS & $\mathrm{P}$ & $\mathrm{Bu}$ & $\mathrm{Kn}, \mathrm{Km}$ \\
\hline Jeruk & Citrus sinensis Osbeck & Rutaceae & KS & $\mathrm{Bd}$ & $\mathrm{Bu}$ & $\mathrm{Kn}$ \\
\hline Johar & Cassia siamea Lamk. & Fabaceae & KS & $\mathrm{Bg}, \mathrm{Rt}$ & $\mathrm{Bt}$ & $\mathrm{Kn}$ \\
\hline Karet & Hevea brasiliensi [Muell.) Arg. & Euphorbiaceae & KS & $\mathrm{KB}$ & $\mathrm{Cb}$ & $\mathrm{Kn}$ \\
\hline Kayu besi & Diospyros celebica Bakh, & Ebenaceae & KS & $\mathrm{Bg}$ & $\mathrm{Bt}$ & $\mathrm{Kn}$ \\
\hline Kayu cina & Dacrydium elatum Wall. & Podocarpaceae & $\mathrm{KS}, \mathrm{KO}$ & 0 & $\mathrm{Bt}, \mathrm{KI}, \mathrm{Gt}$ & $\mathrm{Kn}$ \\
\hline Kayu India & & & $\mathrm{H}$ & $\mathrm{O}$ & $\mathrm{D}$ & $\mathrm{Kn}$ \\
\hline Kayu rita & Alstonia scholaris R.Br. & Apocynaceae & $\mathrm{KS}, \mathrm{H}$ & O & Gt & $\mathrm{Kn}$ \\
\hline Kelapa & Cocos nucifera $\mathrm{L}$. & Arecaceae & KS & $\mathrm{P}, \mathrm{Bg}, \mathrm{Bd}$ & $\mathrm{Bt}, \mathrm{D}, \mathrm{Bu}$ & $\mathrm{Kn}, \mathrm{Km}$ \\
\hline Kemiri & Aleurites moluccana (L.) Willd. & Euphorbiaceae & KS & $\mathrm{P}$ & $\mathrm{Bu}$ & $\mathrm{Km}$ \\
\hline Kenra & & & KS & O & $A$ & $\mathrm{Kn}$ \\
\hline Kopi & Coffea arabica & Rubiaceae & $\mathrm{KS}, \mathrm{KO}, \mathrm{H}$ & $\mathrm{P}, \mathrm{O}, \mathrm{KB}$ & $\mathrm{Cb}, \mathrm{D}, \mathrm{Bu}$ & $\mathrm{Kn}, \mathrm{Km}$ \\
\hline Lada & Piper nigrum L. & Piperaceae & KS & $\mathrm{P}$ & $\mathrm{Bu}$ & $\mathrm{Km}$ \\
\hline Langsat & Lansium domesticum Corr. & Meliaceae & $\mathrm{KS}, \mathrm{H}$ & $\mathrm{P}$ & $\mathrm{Bu}$ & $\mathrm{Kn}, \mathrm{Km}$ \\
\hline Linre & & & $\mathrm{KS}, \mathrm{KO}$ & $\mathrm{KB}$ & $\mathrm{Cb}$ & $\mathrm{Kn}$ \\
\hline Mangga & Mangifera indica & Anacardiaceae & $\mathrm{KS}, \mathrm{H}$ & $\mathrm{P}$ & $\mathrm{Bu}$ & $\mathrm{Kn}$ \\
\hline Manggis & Garcinia mangostana L. & Guttiferaceae & KS & $P, O$ & $\mathrm{Bu}$ & $\mathrm{Kn}$ \\
\hline Moha & & & $\mathrm{H}$ & $\mathrm{O}$ & $\mathrm{KI}$ & $\mathrm{Kn}$ \\
\hline Nangka & Artocarpus heterophyllus Lam. & Moraceae & $\mathrm{KS}, \mathrm{KO}, \mathrm{H}$ & $\mathrm{P}, \mathrm{KB}, \mathrm{Bd}$ & $\mathrm{Cb}, \mathrm{D}, \mathrm{Bu}$ & $\mathrm{Kn}$ \\
\hline Pala & Myristica fragrans Houtt. & Myristicaceae & KS & $\mathrm{P}$ & $\mathrm{Bu}$ & $\mathrm{Km}$ \\
\hline Petai & Parkia speciosa Hassk. & Fabaceae & $\mathrm{KS}, \mathrm{H}$ & $\mathrm{P}$ & $\mathrm{Bu}$ & $\mathrm{Kn}, \mathrm{Km}$ \\
\hline Pinang & Areca catechu L. & Arecaceae & $\mathrm{KS}, \mathrm{H}$ & $\mathrm{O}, \mathrm{Bd}$ & $\mathrm{Bu}$ & \\
\hline Rambutan & Nephelium lappaceum L. & Sapindaceae & $\mathrm{KS}, \mathrm{KO}, \mathrm{H}$ & $\mathrm{P}, \mathrm{Bg}, \mathrm{KB}$ & $\mathrm{Bt}, \mathrm{Cb}, \mathrm{Bu}$ & $\mathrm{Kn}, \mathrm{Km}$ \\
\hline Sagu & Metroxylon sagu Rottb. & Arecaceae & $\mathrm{H}$ & $\mathrm{Bg}$ & $\mathrm{D}$ & $\mathrm{Kn}$ \\
\hline Sengon & Paraserianthes moluccana & Fabaceae & $\mathrm{KS}, \mathrm{KO}, \mathrm{H}$ & $\mathrm{Bg}, \mathrm{Rt}, \mathrm{KB}$ & $\mathrm{Bt}, \mathrm{Cb}$ & $\mathrm{Kn}, \mathrm{Km}$ \\
\hline Sirsak & Annona muricata L. & Annonaceae & $\mathrm{KS}, \mathrm{KO}$ & 0 & $\mathrm{D}$ & $\mathrm{Kn}$ \\
\hline
\end{tabular}




\begin{tabular}{|c|c|c|c|c|c|c|}
\hline \multirow[b]{2}{*}{ Nama lokal } & \multicolumn{2}{|l|}{ Jenis } & \multirow{2}{*}{$\begin{array}{l}\text { Lokasi } \\
\text { pengambilan }\end{array}$} & \multirow{2}{*}{$\begin{array}{c}\text { Jenis } \\
\text { pemanfaatan }\end{array}$} & \multirow{2}{*}{$\begin{array}{l}\text { Bagian yang } \\
\text { dimanfaatkan }\end{array}$} & \multirow{2}{*}{$\begin{array}{c}\text { Tujuan } \\
\text { pemanfaatan }\end{array}$} \\
\hline & Nama ilmiah & Famili & & & & \\
\hline Srikaya & Annona squamosa $\mathrm{L}$. & Annonaceae & $\mathrm{KS}, \mathrm{KO}, \mathrm{H}$ & O & $\mathrm{D}$ & $\mathrm{Kn}$ \\
\hline Sukun & Artocarpus communis Forst. & Moraceae & KS & $\mathrm{P}$ & $\mathrm{Bu}$ & $\mathrm{Kn}, \mathrm{Km}$ \\
\hline Suren & Toona surenii Merr. & Meliaceae & $\mathrm{KS}, \mathrm{H}$ & $\mathrm{Bg}, \mathrm{Rt}$ & $\mathrm{Bt}$ & $\mathrm{Kn}$ \\
\hline Teba Dao & Dracontomelon dao(BI.)Merr.\& Rolfe & Anacardiaceae & $\mathrm{KS}, \mathrm{KO}$ & $\mathrm{O}$ & $\mathrm{D}$ & $\mathrm{Kn}$ \\
\hline
\end{tabular}

Keterangan: $\mathrm{KS}=$ Kebun sendiri $\mathrm{KO}=$ Kebun orang lain; $\mathrm{H}=$ Kawasan hutan; $\mathrm{P}=$ Panan; $\mathrm{O}=$ Obat-obatan; $\mathrm{Bg}=\mathrm{Bahan}$ bangunan; Rt = Alat rumah tangga; $\mathrm{KB}=\mathrm{Kayu}$ bakar; $\mathrm{Bd}=$ Budaya; $\mathrm{A}=$ Akar; $\mathrm{Bt}=$ Batang; $\mathrm{Cb}=$ Cabang/ranting; $\mathrm{D}=$ Daun; Bu = Buah; $\mathrm{KI}=\mathrm{Kulit} ; \mathrm{Gt}=\mathrm{Getah} ; \mathrm{Kn}=\mathrm{Konsumsi}$ sendiri; Km = Komersil 


\section{Pemanfaatan jenis tumbuhan untuk pangan}

Masyarakat di Desa Swatani, Bululohe dan Kindang telah memanfaatkan jenis-jenis pohon untuk kebutuhan makanan terutama jenis buah-buahan seperti: durian, manggis, mangga, nangka, jambu, langsat, rambutan, kelapa, petai, jengkol, kemiri. Sementara itu, ada pula responden yang menanam umbi-umbian seperti ketela pohon untuk tambahan bahan makanan. Jenis lain yang juga dimanfaatkan setelah diolah adalah kopi robusta yang umumnya dibudidayakan di dalam kawasan hutan (terutama di Desa Bululohe) maupun di lahan milik sendiri. Berdasarkan pengamatan di lapangan, hampir seluruh masyarakat di wilayah DAS hulu memiliki tanaman kopi meskipun sebagian hanya menanam pada bagian pagar dan untuk konsumsi sendiri.

Pemanfaatan jenis pohon untuk makanan selain dikonsumsi sendiri juga dijual ke pasar sebagai tambahan pendapatan petani. Jenis pohon yang hasilnya sebagian besar dijual adalah cengkeh, coklat, lada, kopi, pala dan kemiri. Bebapa jenis hanya untuk konsumsi sendiri seperti jambu batu, mangga, manggis dan nangka. Jenis-jenis lainnya dimanfaatkan baik untuk tujuan konsumsi sendiri maupun dijual.

Di Desa Swatani, beberapa penggunaan lahan kebun campuran sebelumnya adalah kebun coklat. Namun, jenis coklat telah banyak diganti dengan jenis lada yang memiliki nilai ekonomis tinggi dengan tingkat ketahanan terhadap hama yang juga relatif lebih baik dibandingkan dengan coklat. Jenis lada banyak dibudidayakan secara intensif oleh petani di Desa Swatani di bawah tegakan pohon. Sementara itu, di Desa Bululohe, jenis-jenis buah-buahan yang telah dibudidayakan sejak lebih dari 5 tahun yang lalu adalah jenis durian, nangka, langsat dan pisang. Di Desa Kindang, jenis-jenis pohon yang dibudidayakan juga relatif tetap sejak lebih dari 5 tahun yang lalu seperti jenis kopi, cengkeh, durian, dan jenis buah-buahan lainnya. Desa Kindang dengan ketinggian tempat yang cukup tinggi merupakan tempat yang baik untuk budidaya kopi.

\section{Pemanfaatan jenis tumbuhan untuk obat-obatan}

Sebagian masyarakat masih memanfaatkan obat-obatan tradisional dari vegetasi yang ada disekitarnya, meskipun sebagian yang lain telah beralih menggunakan obat kimia (i.e. pembelian obat dari toko obat atau apotik). Pengetahuan tentang khasiat tumbuhan obat umumnya diperoleh turun temurun dari orang tua yang banyak menggunakan jenis-jenis tumbuhan seperti disajikan dalam Tabel 3.25 dalam memenuhi kebutuhan akan obat-obatan. Alasan penggunaan obat-obatan tradisional ini adalah karena ketersediaannya pada lahan disekitar mereka, lebih ekonomis karena tidak perlu membeli serta dipercaya lebih aman karena menggunakan bahan alami/herbal.

Jenis pohon yang dimanfaatkan untuk obat-obatan ini paling beragam ketiga setelah bahan bangunan dan pangan. Selain itu bagian-bagian pohon yang dimanfaatkan adalah yang paling beragam dari jenis pemanfaatan lainnya. Bagian pohon yang dimanfaatkan untuk obat-obatan ini dapat meliputi akar, batang, daun, buah, kulit dan getah. Jika penelitian ini tidak dibatasi pada jenis pohon, masyarakat 
sebenarnya juga banyak memanfaatkan jenis-jenis perdu sebagai bahan obat obatan tradisional seperti babadotan, kumis kucing, dan berbagai jenis rumput-rumputan (Lampiran 3.2).

Jenis pohon untuk obat-obatan ini umumnya tidak harus diambil dari lahan milik sendiri, melainkan dapat diambil dari lahan orang lain ataupun kawasan hutan. Sebagaimana dibahas sebelumnya, masyarakat menganggap kebutuhan obat adalah kebutuhan mendesak, serta jenis pemanfaatanya relatif tidak mengganggu kelangsungan hidup pohon. Selain itu, masyarakat umumnya menggunakan hanya untuk konsumsi sendiri dan tidak dijualbelikan.

\section{Pemanfaatan jenis tumbuhan untuk bahan bangunan}

Pemanfaatan pohon untuk bangunan merupakan pemanfaatan yang menggunakan jenis paling beragam. Hal ini berkaitan dengan kebutuhan dalam pembuatan bangunan yang tidak dapat lepas dari bahan baku kayu. Penggunaan kayu sebagai bahan bangunan ini lebih intensif di daerah Kabupaten Bulukumba dan sekitarnya karena masih banyak rumah tradisional berupa rumah panggung. Rumah panggung di daerah ini berupa bangunan dengan konstruksi rangka, tiang, lantai, dinding, kusen, daun pintu dan jendela yang berbahan kayu.
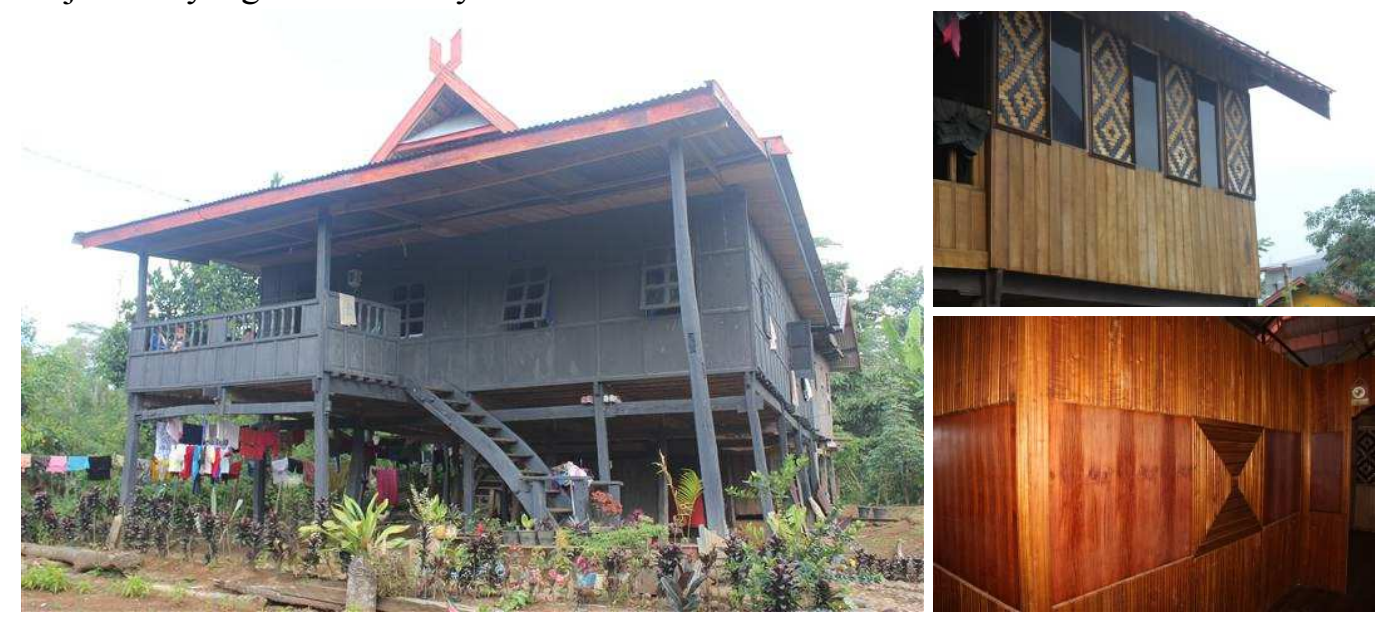

Gambar 3.16 Rumah panggung yang berbahan baku kayu di lokasi penelitian

Beberapa jenis pohon tersebut merupakan jenis yang bernilai ekonomi tinggi seperti jati dan kayu besi. Namun demikian, menurut informasi dari responden, sebagian besar pemanfaatan jenis-jenis tersebut adalah untuk konsumsi sendiri. Pemilik lahan pada umumnya memanfaatkan lahannya untuk jenis-jenis perkebunan seperti coklat, cengkeh, kopi, lada dan lain-lain. Sementara pohon penghasil kayu pertukangan pada umumnya ditanam atau tumbuh untuk dimanfaatkan sendiri pada saat diperlukan untuk bahan bangunan.

Sebagian kecil masyarakat mulai membudidayakan jenis pohon cepat tumbuh antara lain adalah jenis sengon dan gmelina/jati putih untuk tujuan komersil. Sementara itu, jenis lokal Sulawesi yang cukup menjadi primadona (i.e. jenis biti) tidak banyak dibudidayakan oleh masyarakat di DAS Balantieng karena daurnya yang relatif lama. Pada umumnya pemanfaatan jenis biti adalah untuk bahan baku perahu pinisi yang kebetulan tidak ada di DAS Balantieng. 
Jenis lokal kayu yang berasal dari kawasan hutan antara lain adalah: bakang, bisuhu, asah, dan bayam. Karena berada di dalam kawasan hutan produksi terbatas, intensitas pemanfaatan kayu tersebut juga relatif rendah sesuai dengan peraturan perundangan yang berlaku di Kabupaten Bulukumba. Masyarakat biasanya memanfaatkan pohon yang tumbang setelah meminta ijin kepada petugas yang berwenang (Dinas Kehutanan dan Perkebunan Kabupaten Bulukumba). Masyarakat mulai menanam jenis lokal (i.e. asah, bisuhu) di kebun milik mereka bahkan beberapa telah memanfaatkannya. Selain itu, jenis pohon penghasil buah seperti kelapa, nangka, rambutan, dan mangga juga banyak dimanfaatkan sebagai jenis penghasil bahan bangunan ketika hasil buahnya sudah kurang produktif.

\section{Pemanfaatan jenis tumbuhan untuk peralatan rumah tangga}

Selain digunakan sebagai bahan bangunan, pohon juga dimanfaatkan oleh masyarakat untuk kebutuhan peralatan rumah tangga. Peralatan rumah tangga yang menggunakan bahan baku kayu antara lain furniture (meja, kursi, lemari), gagang cangkul, gagang golok/sabit/pisau, dan penumbuk bumbu. Jenis pohon yang banyak dimanfaatkan untuk pembuatan lemari adalah jenis kayu cepat tumbuh seperti gmelina/jati putih, suren, dan sengon. Selain itu, jenis pohon penghasil buah seperti nangka juga dapat digunakan sebagai bahan pembuatan lemari. Beberapa responden membeli perabotan rumah tangga dan bukan memanfaatkan pohon yang ada di lahan milik atau kawasan hutan yang dikelola oleh mereka.

\section{Pemanfaatan jenis tumbuhan untuk kayu bakar}

Sebagian masyarakat masih menggunakan kayu sebagai sumber energi rumah tangga. Masyarakat pada umumnya menggunakan kayu bakar berupa ranting dan cabang pohon mati yang terjatuh di lantai kebun. Pada dasarnya masyarakat tidak mempersyaratkan jenis tertentu untuk keperluan kayu bakar, namun berdasarkan hasil kuisioner jenis terbanyak yang digunakan responden adalah sengon. Diduga hal ini disebabkan karakter ranting sengon yang mudah mati dan jauth secara alami.

Sebagaimana biasanya terjadi pada kebun rakyat di pulau Jawa, masyarakat di lokasi penelitian mengambil cabang dan ranting tersebut baik dari kebun sendiri maupun dari kebun orang lain. Pemanfaatan kayu bakar oleh masyarakat di DAS Balantieng umumnya tidak intensif karena sebagian besar responden telah menggunakan gas LPG untuk memasak. Penggunaan kayu bakar umumnya hanya pada untuk memasak air minum atau ketika ada hajatan yang memerlukan volume masak yang tinggi.

\section{Pemanfaatan jenis tumbuhan untuk budaya}

Selain itu, jenis tumbuhan yang ada di DAS Balantieng telah dimanfaatkan pula oleh masyarakat untuk kebutuhan budaya, terutama untuk pesta pernikahan seperti disajikan dalam Lampiran 3.8. Penggunaan jenis pohon untuk budaya ini paling sedikit ragamnya dibanding jenis pemanfaatan lainnya, yaitu hanya 6 jenis. Bagian yang dimanfaatkan antara lain buah sebagai suguhan maupun hiasan seperti buah pisang, jeruk, nangka dan buah kelapa (sebagai bahan baku masakan). Daun kelapa muda (janur) juga digunakan sebagai simbol pesta pernikahan sebagaimana umumnya di 
daerah lain di Indonesia. Selain itu penggunaan kayu/bambu untuk pembuatan gerbang pada pesta pernikahan merupakan salah satu bentuk pemanfaatan jenis tanaman/tumbuhan untuk budaya yang unik di lokasi penelitian. Keberadaan gerbang bambu/kayu pada suatu rumah bahkan bisa menjadi tanda bahwa di rumah tersebut sudah pernah diadakan pesta pernikahan.

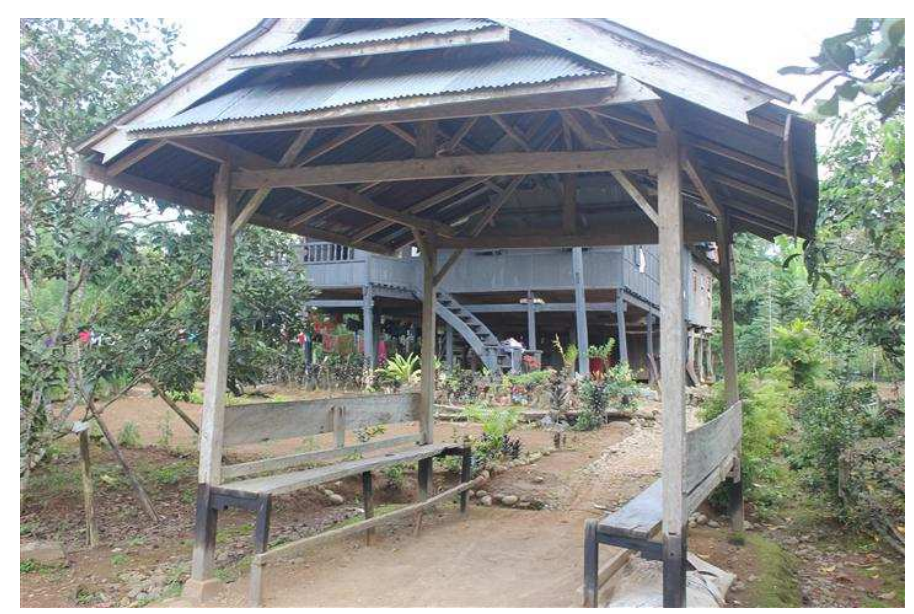

Gambar 3.17 Gerbang dari kayu/bambu yang dibuat pada saat berlangsung pesta pernikahan

\section{Kesimpulan dan Saran}

\subsection{Kesimpulan}

1. Tingkat keanekaragaman hayati dan kekayaan jenis tumbuhan pepohonan pada berbagai SPL agroforestry di sekitar DAS Balangtieng tergolong rendah hingga sedang dengan tingkat keanekaragaman hayati tertinggi berada pada agroforestry kebun campuran dan terendah pada agroforestry jambu mete dengan tingkat kesamaan komunitas antar SPL tergolong rendah hingga sedang.

2. Sebagian besar struktur vegetasi agroforestry di sekitar DAS Balangtieng tidak normal dan kurang menjamin proses regenerasi alami tumbuhan disebabkan adanya pengelolaan yang intensif.

3. Sistem perkebunan intensif menyebabkan berkembangnya jenis-jenis komersil dengan nilai ekonomi tinggi (cengkeh, lada) dan cepat tumbuh (gmelina, suren, afrika) disisi lain menjadi salah satu sebab berkurangnya jenis-jenis asli yang tidak komersial/kurang dikenal atau berdaur lama (seperti pohon Laniki, Bae, Bulo, Rita, Bilalang, Asa dll). Hal ini diindikasikan dengan sebagian besar jenis pohon di hutan alam tidak ditemukan di lahan agroforestry lahan milik.

4. Masyarakat memanfaatkan jenis-jenis pohon untuk makanan, bahan bangunan, obat-obatan dan perkakas rumah tangga. Sebagian besar tujuan pemanfaatan adalah untuk konsumsi/subsisten, dan sebagian lainnya untuk tujuan komersil khususnya pada jenis-jenis yang dibudidayakan secara intensif.

\subsection{Saran/Rekomendasi}

Sistem pertanian/perkebunan intensif dengan pola agroforestry merupakan salah satu bentuk penggunaan lahan yang perlu dipertahankan dan dikembangkan sebagai sumber pendapatan petani. 
Namun demikian diperlukan pengaturan pada skala lanskap agar intensifikasi dan ekstensifikasi perkebunan tersebut tetap mempertimbangkan konservasi biodiversitas untuk mempertahankan keseimbangan ekosistem. Beberapa bentuk pemanfaatan lahan oleh masyarakat yang memiliki nilai keanekaragaman jenis tinggi antara lain sistem kebun campuran, tanaman pagar, dan tanaman/tumbuhan pada bantaran sungai. Oleh karena itu, beberapa upaya yang perlu dipertimbangkan untuk mempertahankan keanekaragaman hayati antara lain:

1. Perlu mempertahankan kebun campuran sebagai kearifan lokal dalam konservasi jenis tumbuhan di hutan milik serta mengisi tanaman pagar dengan variasi jenis pada lahan yang dikelola secara intensif.

2. Perlu melakukan penataan dan penanaman pada hutan kota dan Taman Hutan Raya (Tahura) dengan jenis-jenis lokal sebagai areal sumber daya genetik (ASDG).

3. Perlunya pengembangan pendidikan atau wisata lingkungan berupa pengenalan jenis-jenis lokal (melalui display pada hutan kota dan atau Tahura) terutama kepada generasi muda. Hal ini dimaksudkan untuk mengenalkan dan meningkatkan kesadaran mengenai pentingnya mempertahankan keanekaragaman hayati. 


\section{Daftar Pustaka}

Aini FK, Kurniawan S, Wibawa G dan Hairiah K. 2010. Studi Biodiversitas: Apakah Agroforestri Mampu Mengkonservasi Keanekaragaman Hayati di DAS KONTO. WP0119 World Agroforestry Center (ICRAF).

Badan Pusat Statistik (BPS) Kabupaten Bulukumba, 2012. Kabupaten Bulukumba dalam Angka Tahun 2012.

Beer J, Muschler R, Kass D, Somarriba E. 1998. Shade management in coffee and cacao plantations. In, Directions in Tropical Agroforestry Research. Springer. pp. 139-164.

Bismark M dan Sawitri R. 2006. Pengembangan dan Pengeloaan Daerah Penyangga Kawasan Konservasi. Makalah Utama pada Ekspose Hasil-hasil Penelitian: Konservasi dan Rehabilitasi Sumberdaya Hutan. Padang, 20 September 2006.

BPS Kabupaten Bulukumba, 2015. Statistik Daerah Kabupaten Bulukumba 2015. Badan Pusat Statistik Kabupaten Bulukumba, Bulukumba.

Clough Y, Barkmann J, Juhrbandt J, Kessler M, Wanger TC, AnsharyA, Buchori D, Cicuzza D, Darras K, Putra DD. 2011. Combining high biodiversity with high yields in tropical agroforests. Proceedings of the National Academy of Sciences 108, 8311-8316.

Damanik S. 2007. Strategi pengembangan agribisnis kelapa (Cocos nucifera) untuk meningkatkan pendapatan petani di Kabupaten Indragiri Hilir, Riau. Perspektif 6, 94-104.

De Beenhouwer M, Aerts R, Honnay O. 2013. A global meta-analysis of the biodiversity and ecosystem service benefits of coffee and cacao agroforestry. Agriculture, ecosystems \& environment 175, 1-7.

Hani A, Suryanto P. 2014. Dinamika Agroforestry Tegalan Di Perbukitan Menoreh, Kulon Progo, Daerah Istimewa Yogyakarta. Jurnal Penelitian Kehutanan Wallacea 3, 119-128.

Harada KA, Muzakkir, Rahayu M and Widada. 2001 Traditional People and Biodiversity Conservation in Gunung Halimun National Park. Research and Conservation of Biodiversity in Indonesia Vol II. JICA, Bogor.

Jose S. 2012. Agroforestry for conserving and enhancing biodiversity. Agroforestry Systems 85, 1-8.

Joshi L, Martini E, Nurhariyanto, Prasetio PN, Wulandari D. 2008. A Quick Biodiversity Survey (QBS) for Rapid Agro-biodiversity Appraisal (RABA). World Agroforestry Centre - ICRAF, SEA Regional Office. Bogor, Indonesia.

Kementerian Kehutanan, 2012. Statistik Kehutanan Indonesia 2011. Jakarta

Kepmenhut No. 311/ Kpts-II/2001. Kementerian Kehutanan. Jakarta

Kuncoro SA, van Noordwijk M, Martini E, Saipothong P, Areskoug V, Eka Dinata A dan O'Connor T. 2006. Rapid Agrobiodiversity Appraisal (RABA) in the Context of Environmental Service Rewards. Bogor, Indonesia. World Agroforestry Centre - ICRAF, SEA Regional Office. 106 p.

Magurran AE. 1955. Measuring Biological Diversity. Blackwell publishing. Australia. 256 p.

Martini E, Saad U, Angreiny Y, Roshetko JM. 2014. Kebun Belajar Agroforestri (KBA): Konsep dan Pembelajaran dari Sulawesi Selatan dan Tenggara. In, Seminar Nasional Agroforestri 5 Balai Penelitian Teknologi Agroforestri-Universitas Patimura, Ambon.

Michon G dan Mary F. 2000. Kebun Pepohonan Campuran di Sekitar Bogor Jawa Barat. Dalam Agroforest Khas Indonesia. International Centre For Research In Agroforestry (2000). Hal 137-172.

Millang S. 2015. Struktur dan Komposisi Jenis Agroforestry Kebun-Campuran pada Berbagai Luas Pemilikan Lahan Di Desa Pattalikang Kecamatan Manuju Kabupaten Gowa. Biocelebes 3.

Moço MKS, Gama-Rodrigues EF, Gama-Rodrigues AC, Machado RC, Baligar VC. 2010. Relationships between invertebrate communities, litter quality and soil attributes under different cacao agroforestry systems in the south of Bahia, Brazil. Applied soil ecology 46, 347-354.

Schwendenmann L, Veldkamp E, Moser G, Hoelscher D, Koehler M, Clough Y, Anas I, Djajakirana G, Erasmi S, Hertel D. 2010. Effects of an experimental drought on the functioning of a cacao agroforestry system, Sulawesi, Indonesia. Global Change Biology 16, 1515-1530.

Somarriba E, Beer J. 2011. Productivity of Theobroma cacao agroforestry systems with timber or legume service shade trees. Agroforestry systems 81, 109-121.

Stamps W, Linit M. 1997. Plant diversity and arthropod communities: implications for temperate agroforestry. Agroforestry Systems 39, 73-89. 
Unger IM, Goyne KW, Kremer RJ, Kennedy AC. 2013. Microbial community diversity in agroforestry and grass vegetative filter strips. Agroforestry systems 87, 395-402.

Widiarti A, Prajadinata S. 2008. Karakteristik Hutan Rakyat Pola Kebun Campuran. Jurnal Penelitian Hutan dan Konservasi Alam 5, 145-156. 
Lampiran 3.1 Pemanfaatan jenis tumbuhan untuk makanan di DAS Balantieng

\begin{tabular}{|c|c|c|c|c|c|c|}
\hline \multirow{2}{*}{\multicolumn{2}{|c|}{ SPL }} & \multicolumn{5}{|c|}{ SAAT INI } \\
\hline & & Jenis Kehati & $\begin{array}{l}\text { Lokasi } \\
\text { Pengambilan }\end{array}$ & Luas & $\begin{array}{c}\text { Volume dan } \\
\text { Frekuensi } \\
\text { pemanenan }\end{array}$ & Tujuan Pemanfaatan \\
\hline 1 & $\begin{array}{l}\text { Kebun } \\
\text { Campuran }\end{array}$ & $\begin{array}{l}\text { Pisang (thn tanam } \\
\text { 2010) }\end{array}$ & Kebun milik & 0.5 & 3 tandan/bln & Konsumsi \\
\hline \multirow{4}{*}{2} & \multirow{4}{*}{$\begin{array}{l}\text { Kebun } \\
\text { Campuran }\end{array}$} & Petai 5 pohon & Kebun sendiri & $\begin{array}{l}1 \text { ha }(2 \\
\text { tempat, sekitar } \\
\text { rumah } 1500 \\
\text { m2) }\end{array}$ & hasil penen jelek & \\
\hline & & Rambutan 10 pohon & Kebun sendiri & & 2 karung & $\begin{array}{l}\text { Komsumsi \& bagi } \\
\text { tetangga }\end{array}$ \\
\hline & & Durian, 5 pohon & Kebun sendiri & & $\begin{array}{l}3 \text { phn sdh } \\
\text { berbuah }\end{array}$ & Komsumsi \\
\hline & & Langsat, 50 pohon & Kebun sendiri & & belum berbuah & \\
\hline \multirow{4}{*}{3} & \multirow{4}{*}{$\begin{array}{l}\text { Kebun } \\
\text { campur }\end{array}$} & Durian 3 pohon & $\begin{array}{l}\text { Sekitar } \\
\text { Rumah }\end{array}$ & 2.5 & $\begin{array}{l}\text { Baru belar } \\
\text { berbuah }\end{array}$ & Konsumsi sendiri \\
\hline & & Rambutan 10 pohon & $\begin{array}{l}\text { Kebun (dlm } \\
\text { luasan } 2 \text { ha) }\end{array}$ & & $\begin{array}{l}\text { Baru belar } \\
\text { berbuah }\end{array}$ & Konsumsi sendiri \\
\hline & & Langsat 6 pohon & $\begin{array}{l}\text { Kebun (dlm } \\
\text { luasan } 0,5 \text { ha) }\end{array}$ & & $\begin{array}{l}\text { Baru belar } \\
\text { berbuah }\end{array}$ & Konsumsi sendiri \\
\hline & & Kelapa 1 ha & $\begin{array}{l}\text { Kebun (dlm } \\
\text { luasan } 2 \text { ha) }\end{array}$ & & $\begin{array}{l}\text { diambil buah } \\
\text { kemudian diolah } \\
\text { menjadi kopra }\end{array}$ & $\begin{array}{l}\text { Dijual dalam bentuk kopra } \\
\text { per triwulan @ Rp.4.000- } \\
5.000 / \text { butir. Dijual ke } \\
\text { pengepul @ Rp. } 2.500 / \mathrm{kg} \\
\text { (basah); Rp. } 6.200 / \mathrm{kg} \\
\text { (kering) }\end{array}$ \\
\hline \multirow{5}{*}{4} & \multirow{5}{*}{$\begin{array}{l}\text { Kebun } \\
\text { Campur }\end{array}$} & Langsat & Lahan sendiri & 1 & $20 \mathrm{~kg} / \mathrm{th}$ & Konsumsi \\
\hline & & Rambutan & Lahan sendiri & & $20 \mathrm{~kg} / \mathrm{th}$ & Konsumsi \\
\hline & & Salak & Lahan sendiri & & $\begin{array}{l}20 \text { karung/th }(2 x \\
\text { /th @ } 10 \mathrm{krg}\end{array}$ & $\begin{array}{l}5 \text { Konsumsi dan } 15 \text { krg } \\
\text { dijual @ 70.000/krg }\end{array}$ \\
\hline & & Pisang & Lahan sendiri & & 10 tandan/th & Konsumsi \\
\hline & & Coklat & Lahan sendiri & & $300 \mathrm{~kg}$ kering/th & Jual @ 20.000/kg kering \\
\hline \multirow{8}{*}{5} & \multirow{8}{*}{$\begin{array}{l}\text { Kebun } \\
\text { campur }\end{array}$} & $\begin{array}{l}\text { Salak (banyak) } \\
\text { sebagai tanaman } \\
\text { pagar }\end{array}$ & Lahan sendiri & & 10 karung & Konsumsi \\
\hline & & Rambutam 10 pohon & Lahan sendiri & & 5 karung & Konsumsi \\
\hline & & Langsat 2 pohon & Lahan sendiri & & 1 karung & Konsumsi \\
\hline & & Durian 3 pohon & Lahan sendiri & & $100 \mathrm{biji}$ & Konsumsi \\
\hline & & Sukun 1 pohon & Lahan sendiri & & $100 \mathrm{biji}$ & Konsumsi \\
\hline & & Nangka 5 pohon & Lahan sendiri & & 100biji & Konsumsi \\
\hline & & Paria hutan & Lahan sendiri & & 40 biji & Konsumsi \\
\hline & & Kopi & Lahan sendiri & & $10 \mathrm{~kg}$ & Konsumsi \\
\hline \multirow{4}{*}{6} & \multirow{4}{*}{$\begin{array}{l}\text { Kebun } \\
\text { campur }\end{array}$} & Rambutan & kebun milik & 2.25 & $30 \mathrm{~kg} /$ tahun & Konsumsi \\
\hline & & Durian & kebun milik & & $20 \mathrm{btr} / \mathrm{tahun}$ & Konsumsi \\
\hline & & Coklat & kebun milik & & $\begin{array}{l}50 \text { Itr/ tahun } \\
\text { sudah } 2 \text { tahun } \\
\text { terakhir tdk } \\
\text { panen, masih } \\
\text { diremajakan }\end{array}$ & Jual \\
\hline & & Pisang & kebun milik & & 1 tandan/ 2 bln & Konsumsi \\
\hline \multirow{6}{*}{7} & \multirow{6}{*}{$\begin{array}{l}\text { Kebun } \\
\text { campur }\end{array}$} & Coklat (100 pohon) & Kebun & 0.5 & $50-100 \mathrm{~kg}$ & Jual \\
\hline & & Langsat (6 pohon) & Kebun & & 1 karung & Konsumsi \\
\hline & & Petai (10 pohon) & Kebun & & 50 gantung & Konsumsi \\
\hline & & Rambutan (6 pohon) & Kebun & & 3 karung & Konsumsi \\
\hline & & Kelapa (10 pohon) & Kebun & & $300 \mathrm{bij} / 3 \mathrm{bln}$ & Jual \\
\hline & & Pisang kepok & Kebun & & 100 tandan & Jual \\
\hline
\end{tabular}




\begin{tabular}{|c|c|c|c|c|c|c|}
\hline \multirow{3}{*}{ 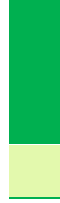 } & \multirow{3}{*}{ SPL } & \multicolumn{5}{|c|}{ SAAT INI } \\
\hline & & Jenis Kehati & $\begin{array}{c}\text { Lokasi } \\
\text { Pengambilan }\end{array}$ & Luas & $\begin{array}{c}\text { Volume dan } \\
\text { Frekuensi } \\
\text { pemanenan }\end{array}$ & Tujuan Pemanfaatan \\
\hline & & Sukun & Kebun & & 100 buah & Jual \\
\hline \multirow{6}{*}{8} & \multirow{6}{*}{$\begin{array}{l}\text { Kebun } \\
\text { campur }\end{array}$} & Durian 5 phn & Kebun & 2.4 & -- & -- \\
\hline & & Nangka 5 phn & Kebun & & $\begin{array}{l}30-50 \mathrm{btr} / \mathrm{phn} / \\
\text { thn }\end{array}$ & Dikonsumsi \\
\hline & & Sukun 4 phn & Kebun & & $5 \mathrm{krg} / \mathrm{thn}$ & Dikonsumsi \& dijual \\
\hline & & Rambutam 4 phn & Kebun & & $3 \mathrm{krg} / \mathrm{thn}$ & Dikonsumsi \& dijual \\
\hline & & Kelapa 150 phn & Kebun & & & $\begin{array}{l}\text { sebagian kecil dikonsumsi, } \\
\text { sebagian besar dijual }\end{array}$ \\
\hline & & Petai & Kebun & & 2 karung & \\
\hline \multirow{9}{*}{9} & \multirow{9}{*}{$\begin{array}{l}\text { Kebun } \\
\text { campur }\end{array}$} & Sukun 1 phn & Pekarangan & 3 & $4 \mathrm{krng} / \mathrm{thn}$ & Konsumsi \\
\hline & & Rambutan 5 phn & Kebun & & $10 \mathrm{krg} / \mathrm{thn}$ & Konsumsi \\
\hline & & Kelapa 15 phn & Kebun & & & Konsumsi \\
\hline & & Kopi (tanaman tepi) & Kebun & & & \\
\hline & & Langsat 1 phn & Pekarangan & & $2 \mathrm{krg} / \mathrm{thn}$ & Konsumsi \\
\hline & & salak 30 rumpun & Pekarangan & & & \\
\hline & & Cengkeh 30 phn & Kebun & & 1 ton/th & \\
\hline & & Coklat 150 phn & & & & \\
\hline & & Nangka 1 phn & & & $20 \mathrm{bh} / \mathrm{thn}$ & \\
\hline \multirow{6}{*}{10} & \multirow{6}{*}{$\begin{array}{l}\text { cengkeh, } \\
\text { rambutan, } \\
\text { sengon, } \\
\text { asa, } \\
\text { gmelina, } \\
\text { bayam } \\
\text { jawa, jabon } \\
\text {, mahoni, } \\
\text { langsat, } \\
\text { pulai }\end{array}$} & Rambutan & $\begin{array}{l}\text { Kasawan } \\
\text { Hutan }\end{array}$ & $\begin{array}{l}0,4 \text { (kawasan } \\
\text { hutan, sejak } \\
\text { tahun 2000) }\end{array}$ & $\begin{array}{l}5 \text { karung/th @ } \\
25 \text { kg }\end{array}$ & $\begin{array}{l}\text { Dijual Rp. } 50.000 \text { - } \\
\text { 100.000/karung }\end{array}$ \\
\hline & & Langsat & $\begin{array}{l}\text { Kasawan } \\
\text { Hutan }\end{array}$ & & 10 karung/th & $\begin{array}{l}\text { Dijual Rp. } 25.000 \text { - } \\
50.000 / k a r u n g, \text { atau } \\
\text { diborong/phn seharga Rp. } \\
\text { 100.000/phn (ada } 5 \text { phon). } \\
3 \text { phn dijual } 2 \text { phn } \\
\text { dikonsumsi }\end{array}$ \\
\hline & & Durian & $\begin{array}{l}\text { Kasawan } \\
\text { Hutan }\end{array}$ & & Belum buah & -- \\
\hline & & Mangga & $\begin{array}{l}\text { Kasawan } \\
\text { Hutan }\end{array}$ & & $\begin{array}{l}\text { Tidak pernah } \\
\text { diambil (1 phn) }\end{array}$ & -- \\
\hline & & Nangka & $\begin{array}{l}\text { Kasawan } \\
\text { Hutan }\end{array}$ & & Belum buah & -- \\
\hline & & $\begin{array}{l}\text { Pisang (Pisang Raja } \\
\text { dan Ambon) }\end{array}$ & $\begin{array}{l}\text { Kasawan } \\
\text { Hutan }\end{array}$ & & 1 tandan/ 2 bln & Komsumsi \\
\hline \multirow[t]{3}{*}{11} & \multirow{3}{*}{$\begin{array}{l}\text { Sengon, } \\
\text { dadap, } \\
\text { Pulai, } \\
\text { mahoni, } \\
\text { cengkeh }\end{array}$} & Langsat 10 pohon & Kebun sendiri & $\begin{array}{l}\text { - 0,25 ha } \\
\text { (kawasan); 0,5 } \\
\text { ha (milik } \\
\text { sendiri) }\end{array}$ & $3 \mathrm{~kg}$ & Komsumsi \\
\hline & & Rambutan 2 pohon & Kebun sendiri & & $5 \mathrm{~kg}$ & Komsumsi \\
\hline & & Durian 2 pohon & Kebun sendiri & & 10 biji & Komsumsi \\
\hline \multirow[b]{3}{*}{12} & \multirow{3}{*}{$\begin{array}{l}\text { Durian, } \\
\text { rambutan, } \\
\text { langsat, } \\
\text { cengkih }\end{array}$} & Durian 5 pohon & $\begin{array}{l}\text { Kasawan } \\
\text { Hutan }\end{array}$ & 0,5 ha (kasaw & & \\
\hline & & Rambutan 4 pohon & $\begin{array}{l}\text { Kasawan } \\
\text { Hutan }\end{array}$ & & 4 karung & \\
\hline & & Langsat 2 pohon & $\begin{array}{l}\text { Kasawan } \\
\text { Hutan }\end{array}$ & & 5 liter & \\
\hline \multirow{5}{*}{13} & \multirow{5}{*}{$\begin{array}{l}\text { Sengon, } \\
\text { lica-lica, } \\
\text { rambutan } \\
\text { hutan, } \\
\text { durian } \\
\text { langsat, } \\
\text { rambutan, } \\
\text { petai, } \\
\text { mangga } \\
\text { laniki (pola } \\
\text { dalam } \\
\text { kawasan); }\end{array}$} & $\begin{array}{l}\text { Langsat }(20 \text { btng } \\
\text { umur } 9 \text { th }\end{array}$ & $\begin{array}{l}\text { Di luar } \\
\text { kawasan }\end{array}$ & $\begin{array}{l}1 \text { ha (dalam } \\
\text { kawasan); } 1 \\
\text { ha (di luar } \\
\text { kawasan) }\end{array}$ & $10 \mathrm{krg} / \mathrm{thn}$ & $\begin{array}{l}\text { Konsumsi; Jual } 5 \text { krg (Rp. } \\
50.000 / k r g)\end{array}$ \\
\hline & & Kopi arabika & $\begin{array}{l}\text { Dalam } \\
\text { kawasan }\end{array}$ & & $\begin{array}{l}100 \text { liter kering } \\
\text { (1 karung) }\end{array}$ & $\begin{array}{l}\text { Konsumsi : } 1 \text { liter/10 hari; } \\
90 \text { liter dijual }\end{array}$ \\
\hline & & $\begin{array}{l}\text { Rambutan (10 } \\
\text { batang) }\end{array}$ & $\begin{array}{l}\text { Di luar } \\
\text { kawasan }\end{array}$ & & $10 \mathrm{krg} / \mathrm{thn}$ & $\begin{array}{l}\text { konsumsi; } 5 \text { karung dijual } \\
@ \text { Rp.50.000/krg }\end{array}$ \\
\hline & & Nangka (10 batang) & $\begin{array}{l}\text { dalam \& luar } \\
\text { kawasan }\end{array}$ & & $100 \mathrm{bh} / \mathrm{thn}$ & Konsumsi \\
\hline & & Kelapa & $\begin{array}{l}\text { Di luar } \\
\text { kawasan }\end{array}$ & & & $\begin{array}{l}\text { Konsumsi; minyak kelapa } \\
\text { (12 buah } \rightarrow 1 \text { Itr minyak) }\end{array}$ \\
\hline
\end{tabular}




\begin{tabular}{|c|c|c|c|c|c|c|}
\hline \multirow{2}{*}{\multicolumn{2}{|c|}{ SPL }} & \multicolumn{5}{|c|}{ SAAT INI } \\
\hline & & Jenis Kehati & $\begin{array}{c}\text { Lokasi } \\
\text { Pengambilan }\end{array}$ & Luas & $\begin{array}{l}\text { Volume dan } \\
\text { Frekuensi } \\
\text { pemanenan }\end{array}$ & Tujuan Pemanfaatan \\
\hline & \multirow{7}{*}{$\begin{array}{l}\text { sutian, } \\
\text { cengkih } \\
\text { (pola di luar } \\
\text { kawasan) }\end{array}$} & $\begin{array}{l}\text { Pisang ambon, raja } \\
\text { emas }\end{array}$ & $\begin{array}{l}\text { dalam \& luar } \\
\text { kawasan }\end{array}$ & & 13 sisir & $\begin{array}{l}\text { Konsumsi; dijual 7000/sisir } \\
\text { (Rp.50.000/bln) }\end{array}$ \\
\hline & & Cengkeh & $\begin{array}{l}\text { dalam \& luar } \\
\text { kawasan }\end{array}$ & & $\begin{array}{l}300 \text { liter } \\
\text { basah } \rightarrow 100 \text { liter } \\
\text { kering; }\end{array}$ & $\begin{array}{l}\text { Harga Rp. } 120.000 / \text { liter; } \\
\text { buruh Rp. } 100.000\end{array}$ \\
\hline & & Lada & & & $10 \mathrm{~kg}$ kering & $10 \mathrm{~kg} \rightarrow$ Rp. 150.000 \\
\hline & & Nanas & & & & \\
\hline & & Coklat & $\begin{array}{l}\text { Dalam } \\
\text { kawasan }\end{array}$ & & 100 liter/thn & dijual Rp. 5000/liter \\
\hline & & Jengkol (2 batang) & & & $30 \mathrm{ltr} / \mathrm{th}$ & dijual Rp. 5000/liter \\
\hline & & Lombok & & & $\begin{array}{l}5 \text { liter; } 4 \\
\text { kali/tahun }\end{array}$ & dijual Rp. 7000/liter \\
\hline \multirow{5}{*}{14} & \multirow{5}{*}{$\begin{array}{l}\text { Cengkeh, } \\
\text { langsat, } \\
\text { rambutan, } \\
\text { bambu, } \\
\text { suren, } \\
\text { mahoni, } \\
\text { asah }\end{array}$} & Langkat 100 pohon & $\begin{array}{l}\text { Dalam } \\
\text { kawasan }\end{array}$ & $\begin{array}{l}1 \text { ha (dalam } \\
\text { kawasan) }\end{array}$ & $\begin{array}{l}10 \text { pohon sudah } \\
\text { berbuah } 2 \\
\text { karung }\end{array}$ & $\begin{array}{l}\text { Dijual Rp. } 100.000 \text { dan } \\
\text { dikonsumsi sendiri }\end{array}$ \\
\hline & & Rambutan 10 pohon & $\begin{array}{l}\text { Dalam } \\
\text { kawasan }\end{array}$ & & $\begin{array}{l}6 \text { pohon sudah } \\
\text { berbuah } 3 \\
\text { karung }\end{array}$ & $\begin{array}{l}\text { Dijual Rp. } 100.000 \text { dan } \\
\text { dikonsumsi sendiri }\end{array}$ \\
\hline & & Pisang 10 pohon & $\begin{array}{l}\text { Dalam } \\
\text { kawasan }\end{array}$ & & 10 tandan & $\begin{array}{l}\text { Dijual dan dikonsumsi } \\
\text { sendiri }\end{array}$ \\
\hline & & Durian 20 pohon & $\begin{array}{l}\text { Dalam } \\
\text { kawasan }\end{array}$ & & $\begin{array}{l}1 \text { pohon sudah } \\
\text { berbuah (100 } \\
\text { buah) }\end{array}$ & $\begin{array}{l}\text { Dijual dan dikonsumsi } \\
\text { sendiri }\end{array}$ \\
\hline & & Petai 4 pohon & $\begin{array}{l}\text { Dalam } \\
\text { kawasan }\end{array}$ & & $\begin{array}{l}\text { semua sudah } \\
\text { berbuah (>1 } \\
\text { karung) }\end{array}$ & $\begin{array}{l}\text { Dijual sebagian dan } \\
\text { dikonsumsi sendiri }\end{array}$ \\
\hline \multirow{3}{*}{15} & \multirow{3}{*}{$\begin{array}{l}\text { Cengkeh, } \\
\text { rambutan, } \\
\text { durian, } \\
\text { karet, } \\
\text { suren, } \\
\text { mahoni, } \\
\text { langsat, } \\
\text { sengon }\end{array}$} & Rambutan 6 pohon & Kebun sendiri & 0,5 ha & $\begin{array}{l}1 \times \text { setahun } 3 \\
\text { karung }\end{array}$ & $\begin{array}{l}\text { Konsumsi sendiri dan } \\
\text { dijual }\end{array}$ \\
\hline & & Durian 8 pohon & Kebun sendiri & & belum berbuah & - \\
\hline & & Langsat 10 pohon & Kebun sendiri & & $\begin{array}{l}2-10 \text { karung per } \\
\text { tahun }\end{array}$ & Dijual \\
\hline \multirow{4}{*}{16} & \multirow{4}{*}{$\begin{array}{l}\text { Durian } 8 \\
\text { pohon, } \\
\text { rambutan } 3 \\
\text { pohon, } \\
\text { cengkeh46 } \\
\text { pohon, } \\
\text { sengon } 1 \\
\text { pohon } \\
\text { mahoni, } \\
\text { suren, jati } \\
15 \text { pohon, } \\
\text { langsat } 1 \\
\text { pohon }\end{array}$} & Durian & $\begin{array}{l}\text { Dalam } \\
\text { kawasan }\end{array}$ & $\begin{array}{l}0,5 \text { ha sawah, } \\
0,25 \text { ha } \\
\text { kawasan }\end{array}$ & $\begin{array}{l}1 \text { pohon sudah } \\
\text { berbuah ( } 30 \\
\text { buah) }\end{array}$ & Dikonsumsi sendiri \\
\hline & & Rambutan & $\begin{array}{l}\text { Dalam } \\
\text { kawasan }\end{array}$ & & $2 \times$ panen & Dikonsumsi sendiri \\
\hline & & Langsat & $\begin{array}{l}\text { Dalam } \\
\text { kawasan }\end{array}$ & & $2 \times$ panen & Dikonsumsi sendiri \\
\hline & & Pisang & $\begin{array}{l}\text { Dalam } \\
\text { kawasan }\end{array}$ & & $2 \times$ panen & Dijual Rp.3000/sisir \\
\hline \multirow[b]{3}{*}{17} & \multirow{3}{*}{$\begin{array}{l}\text { Kawasan: } \\
\text { Mahoni, } \\
\text { pulai, } \\
\text { durian, } \\
\text { langsat, } \\
\text { sengon, } \\
\text { cengkeh; } \\
\text { Lahan Milik } \\
\text { : jati, } \\
\text { langsat, } \\
\text { durian, } \\
\text { sengon, } \\
\text { mahoni, } \\
\text { rambutan }\end{array}$} & $\begin{array}{l}\text { Langsat (mulai panen } \\
\text { tahun 2012) }\end{array}$ & $\begin{array}{l}\text { - Kawasan } \\
\text { - Lahan Milik }\end{array}$ & $\begin{array}{l}0,75 \text { ha } \\
\text { kawasan; 0,5 } \\
\text { ha Iahan milik }\end{array}$ & $\begin{array}{l}-20 \mathrm{~kg} / \mathrm{th} \\
-100 \mathrm{~kg} / \mathrm{th}\end{array}$ & $\begin{array}{l}\text { - konsumsi } \\
\text { Konsumsi }\end{array}$ \\
\hline & & Rambutam & Lahan milik & & $50 \mathrm{~kg} / \mathrm{th}$ & Konsumsi \\
\hline & & Pisang & Lahan milik & & 15 tandan/th & $\begin{array}{l}12 \text { dikonsumsi, } 3 \text { dijual @ } \\
\text { Rp.20.000 }\end{array}$ \\
\hline \multirow{3}{*}{18} & \multirow{3}{*}{$\begin{array}{l}\text { Cengkeh, } \\
\text { langsat, } \\
\text { durian }\end{array}$} & 3 pohon durian & & 0,5 ha & $1 \times 1$ thn & Konsumsi sendiri \\
\hline & & 15 pohon langsat & & & 3 keranjang & sebagian dijual \\
\hline & & 3 pohon pisang & & & tdk menentu & Konsumsi sendiri \\
\hline 19 & $\begin{array}{l}\text { Mahoni, } \\
\text { cengkeh }\end{array}$ & Cengkeh 300 btng & $\begin{array}{l}\text { Kebun \& } \\
\text { kawasan }\end{array}$ & 2 ha & $100 \mathrm{ltr} / \mathrm{th}$ & Dijual : Rp. 125.000/kg \\
\hline
\end{tabular}




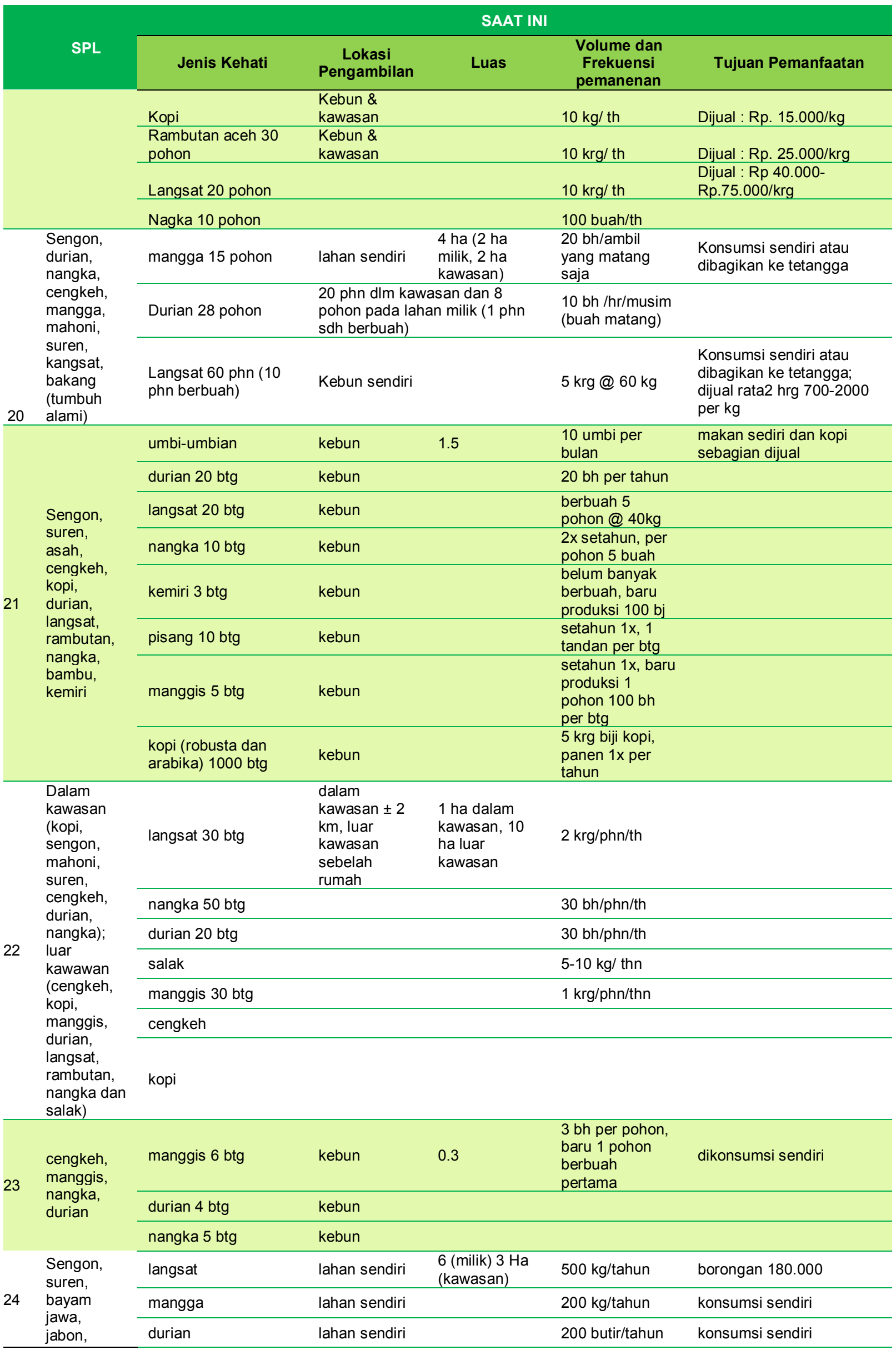




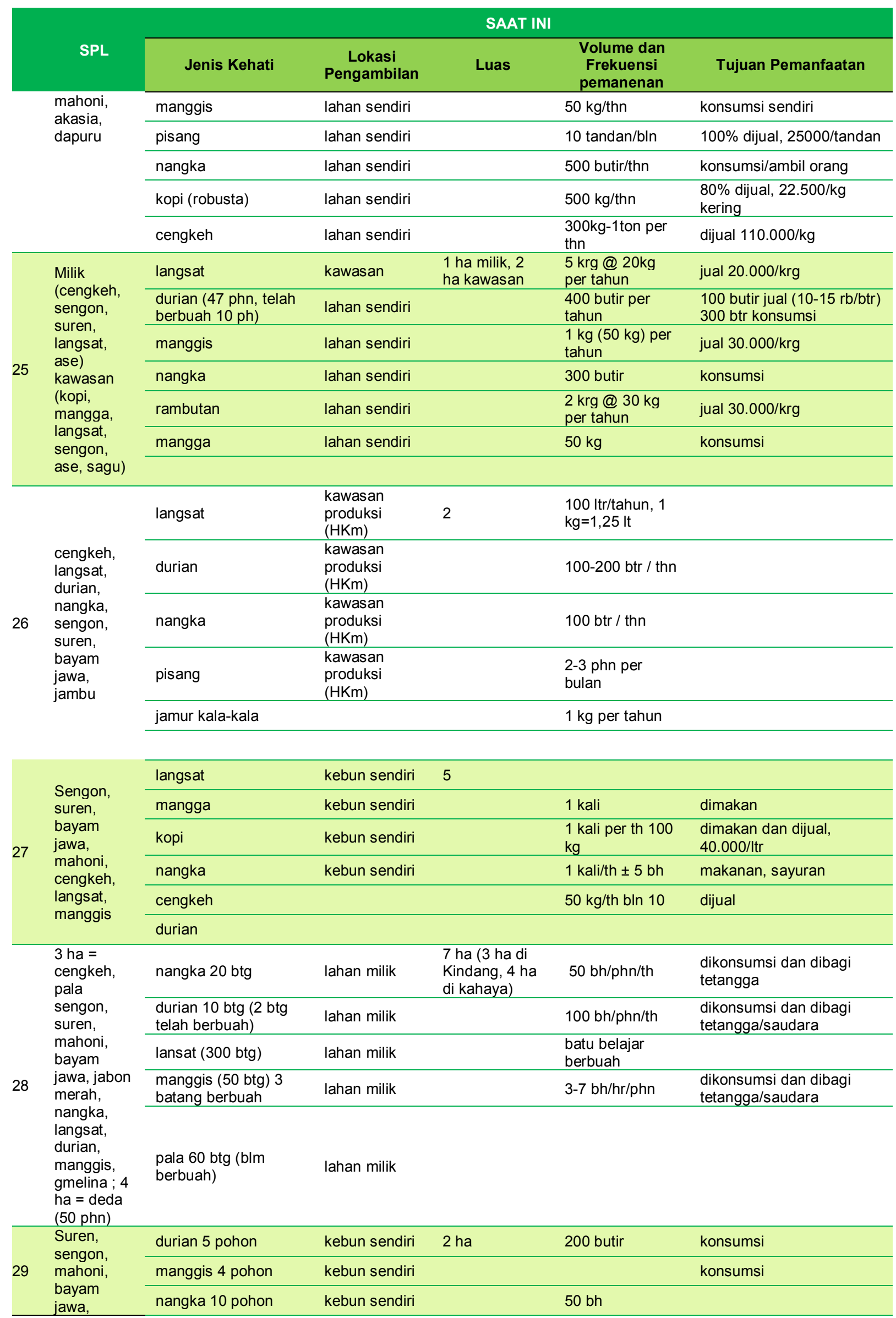




\section{SAAT INI}

SPL

Jenis Kehati $\quad \begin{gathered}\text { Lokasi } \\ \text { Pengambilan }\end{gathered}$

Luas

Volume dan

Frekuensi

Tujuan Pemanfaatan

bakau

kebun sendiri

merah,

jambu batu 1 pohon

pemanenan

cengkeh

\begin{tabular}{ll}
\hline lansat 6 pohon & kebun sendi \\
\hline kopi robusta & kebun sendi
\end{tabular}

6 karung

cengkeh

kebun sendiri

$150 \mathrm{~kg}$ per tahun jual $22,5 \mathrm{rb} / \mathrm{kg}$

$110 \mathrm{~kg}$

jual $110 \mathrm{rb} / \mathrm{kg}$ 
Lampiran 3.2 Pemanfaatan jenis tumbuhan untuk obat-obatan di DAS Balantieng

\begin{tabular}{|c|c|c|c|}
\hline Jenis tumbuhan & $\begin{array}{c}\text { Lokasi } \\
\text { Pengambilan }\end{array}$ & $\begin{array}{l}\text { Volume dan Frekuensi } \\
\text { pemanenan }\end{array}$ & Tujuan Pemanfaatan \\
\hline $\begin{array}{l}\text { Rebusan daun sirsak } \\
\text { (mulai tahun 2013). } \\
\text { Kumis Kucing, kunyit, } \\
\text { Jahe. }\end{array}$ & Kebun milik & 7 lembar/hari & obat asam urat \\
\hline $\begin{array}{l}\text { Buah \& daun mahkota } \\
\text { dewa }\end{array}$ & Kebun milik & & untuk mengobati penyakit dalam \\
\hline Daun geji & Kebun milik & & untuk mengobati tekanan darah tinggi/kolestrol \\
\hline Daun yodium hidup & Kebun milik & & obat luka \\
\hline $\begin{array}{l}\text { Daun Gedi (seperti } \\
\text { daun pepaya) }\end{array}$ & Kebun & $\begin{array}{l}\text { 3-7 lembar, direbus dlm 1-2 } \\
\text { gelas air setelah dingin } \\
\text { diminum } 1 \text { x sehari (pagi) }\end{array}$ & untuk menurunkan kolestrol/tensi \\
\hline Daun Kopi & Kebun & & untuk menurunkan kolestrol/tensi \\
\hline Daun Srikaya & Kebun & & untuk asam urat, pusing-pusing, tensi juga \\
\hline Daun sambiloto & Kebun & & untuk menurunkan tensi, gula \\
\hline Kulit manggis & Kebun & & untuk mengatasi keputihan \\
\hline Daun Bila (Berenuk) & Kebun & & untuk mengatasi mag + gula \\
\hline Kunyit putih & Kebun & & untuk menghilangkan nyeri haid. \\
\hline \multicolumn{4}{|l|}{$\begin{array}{l}\text { Jahe, kumis kucing, } \\
\text { sirih, kencur, kunyit }\end{array}$} \\
\hline Yodium hidup & Kebun & & getahnya untuk luka baru \\
\hline $\begin{array}{l}\text { Bangke jarang } \\
\text { (Babadotan) }\end{array}$ & Kebun & & $\begin{array}{l}\text { Daun dan batangnya digunakan untuk luka } \\
\text { baru }\end{array}$ \\
\hline Paria & Kebun & & $\begin{array}{l}\text { Air rebusan daun paria diminum } 3 \times \text { sehari } \\
\text { untuk mengatasi batuk }\end{array}$ \\
\hline Jahe & Kebun & & $\begin{array}{l}\text { Air rebusan rimpang jahe diminum untuk } \\
\text { mengatasi batuk }\end{array}$ \\
\hline Sambiloto & Kebun & 5-9 lembar & $\begin{array}{l}\text { Air rebusan } 5-9 \text { lembar daun sambiloto dapat } \\
\text { mengatasi batuk }\end{array}$ \\
\hline Jahe & Halaman rumah & 1 rimpang/ bln & Konsumsi (wedang jahe/saraba) \\
\hline Kunyit & Halaman rumah & tidak tentu & Konsumsi \\
\hline Mahkota dewa & Halaman rumah & tidak tentu & $\begin{array}{l}\text { Katanya untuk penyakit dalam (belum pernah } \\
\text { pakai) }\end{array}$ \\
\hline Daun mayana & sekitar rumah & 3-9 daun & obat TBC \\
\hline Kunyit & sekitar rumah & $3 \times$ sehari & obat TBC \\
\hline Jahe & sekitar rumah & 1 rimpang & obat TBC \\
\hline Akar pepaya (kaniki) & sekitar rumah & 1 jengkal & $\begin{array}{l}\text { obat penurun panas (rebusannya diminum } 3 \times \\
\text { sehari) }\end{array}$ \\
\hline Jambu batu merah & sekitar rumah & & obat mencret \\
\hline $\begin{array}{l}\text { Kayu cina (hati bagian } \\
\text { dalam) }\end{array}$ & & & obat luka \\
\hline Getah yodium & & & obat luka \\
\hline Getah pisang & & & obat luka \\
\hline Daun kopi & Kebun & $\pm 5 x$ & air rebusannya untuk menurunkan tensi \\
\hline Daun srikaya & Kebun & $\pm 2 x / \mathrm{bln}$ & air rebusannya untuk rematik \& pusing-pusing \\
\hline Daun sirsak & Kebun & $\pm 2 x / \mathrm{bln}$ & air rebusannya untuk rematik \& pusing-pusing \\
\hline Daun berenuk & Kebun & $\pm 3 x /$ bln & air rebusannya untuk diabetes \& mag \\
\hline Daun gedi & Pekarangan & $\pm 10 \mathrm{x} / \mathrm{bln}$ & air rebusannya untuk kolestrol \\
\hline Daun pepaya & Kebun & tergantung kondisi & air rebusannya untuk demam \& malaria \\
\hline Akar alang-alang & Kebun & Jarang & air rebusannya untuk rematik \\
\hline Akar cana gori & Kebun & Jarang & air rebusannya untuk rematik \\
\hline Daun sirih & Kebun & $2 \times$ setahun & air rebusannya untuk keputihan \& gatal-gatal \\
\hline
\end{tabular}




\begin{tabular}{|c|c|c|c|}
\hline Jenis tumbuhan & $\begin{array}{l}\text { Lokasi } \\
\text { Pengambilan }\end{array}$ & $\begin{array}{l}\text { Volume dan Frekuensi } \\
\text { pemanenan }\end{array}$ & Tujuan Pemanfaatan \\
\hline Daun jambu biji & & & air rebusannya untuk sakit perut \\
\hline Daun srikaya & & & air rebusannya untuk sakit kepala \\
\hline Srikaya (daunnya) & Kasawan Hutan & $\begin{array}{l}\text { tiap } 3 \text { hari. } 30 \text { lembar daun } \\
\text { (dimasak tiap hari } 10 \text { lembar) }\end{array}$ & obat/kesehatan. Direbus, diminum pagi \& sore \\
\hline Jarak (daunnya) & Kasawan Hutan & 5-6 kali/tahun @ 4 lembar & Obat hipertensi \\
\hline Temu lawak, Kunyit & $\begin{array}{l}\text { Sekarang beli di } \\
\text { pasar }\end{array}$ & & \\
\hline Pepaya (daunnya) & Lahan sendiri & tiap bulan 2 lembar & $\begin{array}{l}\text { Obat pegal-pegal, flu, meriang, capek } \\
\text { (daunnya diblender) }\end{array}$ \\
\hline Srikaya & Kebun & 7 lembar & $\begin{array}{l}\text { Untuk sakit kepala; } 7 \text { lembar daun dicampur } \\
\text { air hangat diminum dan dibalurkan ke perut } \\
\text { (khusus bayi) }\end{array}$ \\
\hline Tangin-tangin (jarak) & Kebun & 3 lembar & $\begin{array}{l}\text { Untuk penambah nafsu makan anak-anak; } 3 \\
\text { lembar daun jarak diperas, air perasannya } \\
\text { ditempelkan dijung lidah anak }\end{array}$ \\
\hline Kayu cina & Kebun & & $\begin{array}{l}\text { Obat batuk; kulitnya dimasak kemudian air } \\
\text { rebusannya diminum. Untuk luka : kulit bagian } \\
\text { dalam dikerik kemudian ditempelkan pada } \\
\text { yang luka }\end{array}$ \\
\hline Brotowali (Kalelepai) & Kebun & & $\begin{array}{l}\text { Penambah nafsu makan: batang direbus dan } \\
\text { air rebusannya diminum }\end{array}$ \\
\hline Sirih rambah (ma'daun & Kebun & & $\begin{array}{l}\text { Untuk mimisan: daun diremas di tempel di } \\
\text { hidung dan ubun-ubun }\end{array}$ \\
\hline Lidah buaya & Kebun & & $\begin{array}{l}\text { Untuk penyubur rambut : bagian dalam } \\
\text { (daging daun) diremas-remas pada kepala }\end{array}$ \\
\hline Daun Jambu batu & Kebun & & Untuk obat mencret: pucuknya dikunyah \\
\hline Daun cemangi & $\begin{array}{l}\text { Dalam kawasan } \\
\text { hutan }\end{array}$ & 3 ranting daun & untuk mengatasi sakit perut \\
\hline Daun pepaya & $\begin{array}{l}\text { Dalam kawasan } \\
\text { hutan }\end{array}$ & 2-3 lembar daun pepaya & untuk mengatasi sakit demam \\
\hline Rumput ruku-ruku & $\begin{array}{l}\text { Dalam kawasan } \\
\text { hutan }\end{array}$ & secukupnya & untuk mengatasi luka \\
\hline $\begin{array}{l}\text { Daun pepaya (mulai } \\
\text { tahun 2010) }\end{array}$ & Lahan milik & $\begin{array}{l}1 \mathrm{lbr} / \text { pengambilan (dlm } 1 \text { thn } \\
10 \text { lembar) }\end{array}$ & Obat demam berdarah, malaria \\
\hline Daun srikaya & Lahan milik & $\begin{array}{l}9 \mathrm{lbr} / \text { pengambilan }(10 \\
\text { ngambil/th) }\end{array}$ & Obat pegal-pegal \\
\hline Kayu cina & & & obat luka \\
\hline Kunyit hitam & Kebun & & $\begin{array}{l}\text { Obat sakit perut: Kuntit hitam dirarut, sth itu } \\
\text { parutannya dicampur air sambil diremas- } \\
\text { remas, air perasannya diminum }\end{array}$ \\
\hline Daun Srikaya & Kebun & & $\begin{array}{l}\text { Obat pusing/demam: minum rebusan daun } \\
\text { srikaya. Untuk bayi sakit Panas : daun srikaya } \\
\text { diremas kemudian ditempelkan ke keningnya. }\end{array}$ \\
\hline Akar kenra & Kebun & & $\begin{array}{l}\text { Obat sakit pinggang: minum air rebusan akar } \\
\text { kenra } 1 \mathrm{x} \text { sehari }\end{array}$ \\
\hline Teba dao & Kebun & & $\begin{array}{l}\text { Obat batuk TBC: Daun yang telah kering } \\
\text { direbus, air rebusannya diminum } 3 x \text { sehari }\end{array}$ \\
\hline Daun Pepaya & Kebun & & $\begin{array}{l}\text { Obat batuk : Daun pepaya direbus, air } \\
\text { rebusannya diminum } 3 x \text { sehari }\end{array}$ \\
\hline Badotan (campacuni) & Kebun & & $\begin{array}{l}\text { Obat luka: tempelkan daun bandotan yang } \\
\text { telah diremas-remas }\end{array}$ \\
\hline Dilahuna & Kebun & & Obat tetes mata \\
\hline Daun jarak & Kebun & & $\begin{array}{l}\text { Obat pasca melahirkan: } 3 \text { lembar daun jarak } \\
\text { direbus, air rebusannya diminum. Selain itu } \\
\text { digunakan juga unt obat lelah }\end{array}$ \\
\hline $\begin{array}{l}\text { Akar Tuka Buha-buha } \\
\text { (sanrego) }\end{array}$ & Kebun & & Obat stamina laki-laki \\
\hline Kayu cina & Kebun & & $\begin{array}{l}\text { Obat luka dalam: kulit bagian dalam direbus } \\
\text { diminum } 1 \text { x sehari. Untuk luka luar diteteskan }\end{array}$ \\
\hline Saru-saru & sekitar rumah & & sakit kepala/perut \\
\hline Moha (kulit) & kawasan & & sakit perut \\
\hline $\begin{array}{l}\text { Lelang Banoa } \\
\text { (daunnya) }\end{array}$ & sekitar rumah & & sakit kepala \\
\hline
\end{tabular}




\begin{tabular}{|c|c|c|c|}
\hline Jenis tumbuhan & $\begin{array}{c}\text { Lokasi } \\
\text { Pengambilan } \\
\end{array}$ & $\begin{array}{l}\text { Volume dan Frekuensi } \\
\text { pemanenan }\end{array}$ & Tujuan Pemanfaatan \\
\hline Tabulaku (tunas) & kawasan/ kebun & & sakit kepala \\
\hline Daun jambu batu & $\begin{array}{l}\text { sekitar rumah/ } \\
\text { kebun }\end{array}$ & & sakit perut \\
\hline Kayu rita & hutan & $\begin{array}{l}\text { tergantung kebutuhan }(2 x \text { per } \\
\text { tahun) }\end{array}$ & sakit perut dan cacingan, diambil getahnya \\
\hline Jambu batu & hutan & $\begin{array}{l}\text { tergantung kebutuhan ( } 5 x \text { per } \\
\text { tahun) }\end{array}$ & $\begin{array}{l}\text { sakit perut (pucuk daun) penambah selera } \\
\text { makan }\end{array}$ \\
\hline $\begin{array}{l}\text { Tambara kaleleng } \\
\text { (Ficus sp) }\end{array}$ & hutan & $\begin{array}{l}\text { tergantung kebutuhan ( } 1 \times \text { per } \\
\text { tahun) }\end{array}$ & obat luka sekali dipakai saat luka \\
\hline Daun ubi kayu & hutan & $\begin{array}{l}\text { tergantung kebutuhan ( } 36 x \text { per } \\
\text { tahun) }\end{array}$ & obat luka sekali dipakai saat luka \\
\hline $\begin{array}{l}\text { Rumput ruku-ruku, } \\
\text { pakis }\end{array}$ & hutan & $\begin{array}{l}\text { tergantung kebutuhan ( } 1 \mathrm{x} \text { per } \\
\text { tahun) }\end{array}$ & obat gatal, sekali dipakai saat gatal \\
\hline Kayu india & hutan & $\begin{array}{l}\text { tergantung kebutuhan }(2-3 x \text { per } \\
\text { tahun) }\end{array}$ & $\begin{array}{l}\text { diabetes } 2-5 \text { lembar, daun dimasak, sekali } \\
\text { sehari, } 1 \text { bln penuh setiap hari }\end{array}$ \\
\hline Pinang & hutan & $\begin{array}{l}\text { tergantung kebutuhan (1x per } \\
\text { tahun, } 1 \text { biji) }\end{array}$ & $\begin{array}{l}\text { obat kuat dan penyakit dalam, } 1 \text { biji ditumbuk } \\
\text { dan dikunyah }\end{array}$ \\
\hline Kayu dingin (menjalar) & hutan & $\begin{array}{l}\text { tergantung kebutuhan ( } 1 \times \text { per } \\
\text { tahun } 1-2 \text { lembar) }\end{array}$ & penurun panas \\
\hline Daun pepaya & hutan & $\begin{array}{l}\text { tergantung kebutuhan ( } 1 \times \text { per } \\
\text { tahun 2-3 lembar) }\end{array}$ & penurun panas \\
\hline $\begin{array}{l}\text { Kayu rita, daun jambu } \\
\text { batu, kuku bembeh }\end{array}$ & kebun sendiri & & obat sakit perut \\
\hline $\begin{array}{l}\text { Rumput kuku bembeh, } \\
\text { getah, pelepah pisang }\end{array}$ & kebun & & obat luka \\
\hline $\begin{array}{l}\text { Daun pepeya } \\
\text { (diminum) dan } \\
\text { leklembanoa, daun } \\
\text { sirsak }\end{array}$ & & & obat demam \\
\hline Kulit manggis & & & obat penyakit dalam \\
\hline Daun pepaya & & & meningkatkan stamina \\
\hline Jahe & kebun sendiri & & obat dalam \\
\hline Brotowali & kebun sendiri & & sakit perut \\
\hline $\begin{array}{l}\text { Kulit pohon/akar } \\
\text { durian }\end{array}$ & kawasan hutan & $10 \times 5 \mathrm{~cm}, 2-3 \times$ per tahun & konsumsi \\
\hline Daun jambu & kawasan hutan & $5 \mathrm{~g}, 2-3 x$ per tahun & konsumsi \\
\hline Rumput paka'w & kebun & obat luka & \\
\hline Gula merah+garam & kebun & obat batuk & \\
\hline Kaliki (pepaya) & kebun & $\begin{array}{l}\text { demam, pegal } 2 \text { ( } 3 \mathrm{lbr} \text { daun }+2 \\
\text { gelas air direbus menjadi } 1 \\
\text { gelas) }\end{array}$ & \\
\hline Paria & kebun & pancing & \\
\hline Lambiri & kebun & obat mencret & \\
\hline Daun tobo-tobo & & $\begin{array}{l}\text { obat dahak (daun dipanaskan } \\
\text { diatas api, ditempel pada ubun- } \\
\text { ubun bayi) }\end{array}$ & \\
\hline Saru-saru (daunnya) & $\begin{array}{l}\text { tumbuh alami di } \\
\text { kebun }\end{array}$ & $\begin{array}{l}\text { 3-5 lbr daun muda diperas dan } \\
\text { diambil airnya kemudian } \\
\text { diminum }\end{array}$ & untuk obat sakit perut \\
\hline Daun paria & $\begin{array}{l}\text { tumbuh di } \\
\text { kebun/ditanam }\end{array}$ & $\begin{array}{l}\text { 3-5 lbr daun muda diperas dan } \\
\text { diambil airnya kemudian } \\
\text { diminum }\end{array}$ & untuk obat batuk \\
\hline $\begin{array}{l}\text { Daun jambu batu } \\
\text { merah }\end{array}$ & di kebun & $\begin{array}{l}\text { 3-5 lbr daun muda diperas dan } \\
\text { diambil airnya kemudian } \\
\text { diminum }\end{array}$ & untuk obat sakit perut \\
\hline Daun pepaya & di kebun & $\begin{array}{l}1 \mathrm{lbr} \text { yang muda diperas dan } \\
\text { diambil airnya kemudian } \\
\text { diminum }\end{array}$ & untuk obat sakit perut \\
\hline Rumput kambing & di kebun & $\begin{array}{l}\text { 3-5 lbr daun muda diperas } \\
\text { sampai keluar airnya dan } \\
\text { diteteskan ke mata }\end{array}$ & untuk obat tetes mata \\
\hline
\end{tabular}




\begin{tabular}{|c|c|c|c|}
\hline Jenis tumbuhan & $\begin{array}{c}\text { Lokasi } \\
\text { Pengambilan } \\
\end{array}$ & $\begin{array}{l}\text { Volume dan Frekuensi } \\
\text { pemanenan }\end{array}$ & Tujuan Pemanfaatan \\
\hline $\begin{array}{l}\text { Kulit kayu cina dan } \\
\text { getahnya }\end{array}$ & di kebun & $\begin{array}{l}\text { kulit kayu cina direbus dari } 3 \\
\text { gelas menjd } 1 \text { gelas }\end{array}$ & $\begin{array}{l}\text { untuk obat sakit batuk/sakit dada, getahnya } \\
\text { untuk obat luka/digigit serangga }\end{array}$ \\
\hline Jambu batu & & 3 pucuk dikunyah langsung & \\
\hline Daun alpukat & & $3 \mathrm{lbr}$ direbus $3 x$ sehari & \\
\hline Rumput & & air remasan ditetes ke luka & \\
\hline Rumput kambing & & air remasan ditetes ke luka & \\
\hline \multicolumn{4}{|l|}{ Kunyit + kapur } \\
\hline Kumis kucing & & $\begin{array}{l}\text { daun segenggam direbus terus } \\
\text { diminum } 3 x\end{array}$ & \\
\hline Kayu rampe (benalu) & & $\begin{array}{l}\text { daun segenggam direbus terus } \\
\text { diminum } 3 x\end{array}$ & \\
\hline Akar baran-barang & & kulit direbus & \\
\hline Kayu cina & & kulit direbus & \\
\hline
\end{tabular}


Lampiran 3.3 Pemanfaatan jenis tumbuhan untuk bahan bangunan di DAS Balantieng

\begin{tabular}{|c|c|c|c|}
\hline Jenis Kehati & $\begin{array}{l}\text { Lokasi } \\
\text { Pengambilan }\end{array}$ & $\begin{array}{l}\text { Volume dan Frekuensi } \\
\text { pemanenan }\end{array}$ & Tujuan Pemanfaatan \\
\hline Sengon & Dari Kebun & $7 \mathrm{~m}^{3}$ & untuk dinding, lantai, kaso-kaso \\
\hline Mangga & Dari Kebun & $0,5 \mathrm{~m}^{3}$ & untuk lantai \\
\hline Bitih & Dari Kebun & $1 \mathrm{~m}^{3}$ & untuk tangga dan listplang \\
\hline Batang kelapa & Dari Kebun & $1 \mathrm{~m}^{3}$ & Palang dudukan lantai, kuda-kuda \\
\hline Jati Putih & Kebun sendiri & 20 pohon $\left(7 \mathrm{~m}^{3}\right)$ & untuk bangun rumah/ rangka rumah \\
\hline Kayu Bitih & Kebun sendiri & 5 pohon & untuk bangun rumah/ daun jendela \\
\hline Jati putih & Kebun & 10 pohon $\left(2 \mathrm{~m}^{3}\right)$ & Untuk rumah \\
\hline Korek (sengon) & Kebun & & \\
\hline \multicolumn{4}{|l|}{$\begin{array}{l}\text { Papan meranti (beli jadi), } \\
\text { sengon putih }\end{array}$} \\
\hline Jati putih & Kebun & $\begin{array}{l}3 \mathrm{~m}^{3} \text { (umur } 7 \text { thn saat } \\
\text { ditebang) }\end{array}$ & $\begin{array}{l}\text { Tiang, balok, daun pintu, kusen } \\
\text { jendela }\end{array}$ \\
\hline Jati putih & pekarangan & & \\
\hline Biti & & & kusen, daun pintu, balok, rangka atap \\
\hline Sengon & Kasawan Hutan & 1 phn $\left(2 \mathrm{~m}^{3}\right)$ & $\begin{array}{l}\text { Renovasi (Rangka atap, plafon dan } \\
\text { dinding) }\end{array}$ \\
\hline Rambutan hutan & Belakang rumah & $2 \mathrm{phn}\left(1,5 \mathrm{~m}^{3}\right)$ & dipakai sendiri unt memperbaiki rumah \\
\hline Kayu rambutan & Kawasan hutan & 2 phn $\left(0,5 \mathrm{~m}^{3}\right)$ & $\begin{array}{l}\text { untuk memperbaiki rumah (rangka } \\
\text { rumah) }\end{array}$ \\
\hline $\begin{array}{l}\text { Kayu Nangka, Bilalang, } \\
\text { Rambutan hutan }\end{array}$ & & & Balok \\
\hline Bayam & & & Rangka, kaso-kaso, pintu dan kusen \\
\hline Sengon & Kawasan Hutan & 10 pohon dalam 10 tahun & \\
\hline Rambutan & Kawasan Hutan & 5 pohon & \\
\hline Sengon & Dalam kawasan & $1 \mathrm{x}=1 \mathrm{~m}^{3} \mathrm{dlm}$ bentuk papan $(40$ & lembar) \\
\hline $\begin{array}{l}\text { Sengon (untuk papan). } \\
\text { Sengon } 1,5 \text { juta/m3 }\end{array}$ & Kebun & $1 \mathrm{~m}^{3}$ & Rumah \\
\hline Kayu besi ( untuk kusen) & Kebun & $1 \mathrm{~m}^{3}$ & \\
\hline Jati ( untuk pintu, balok) & Kebun & $1 \mathrm{~m}^{3}$ & Di jual dan bikin rumah \\
\hline \multicolumn{4}{|l|}{$\begin{array}{l}\text { Rambutan hutan, nato, } \\
\text { mangga macan. Harga } \\
\text { rambutan hutan Rp. } 3 \mathrm{jt} / \mathrm{m} 3\end{array}$} \\
\hline Sengon & Iahan milik & $3 \mathrm{~m}^{3}$ & untuk bangun rumah sendiri Th. 2014 \\
\hline Bakang & Iahan milik & $1 \mathrm{~m}^{3}$ & \\
\hline Kupang & Iahan milik & $0,5 \mathrm{~m}^{3}$ & \\
\hline Johar & Iahan milik & $0,5 \mathrm{~m}^{3}$ & \\
\hline Suren & Iahan milik & $0,5 \mathrm{~m}^{4}$ & \\
\hline Sengon & hutan & 2 pohon, $1 \times 5$ th $\left(1,5 \mathrm{~m}^{3}\right)$ & papan balok \\
\hline Nangka & hutan & 1 pohon dlm 10 th $\varnothing \pm 25 \mathrm{~cm}$ & benteng (tiang) \\
\hline Suren & hutan & 1 pohon dlm 10 th $\varnothing \pm 25 \mathrm{~cm}$ & balok \\
\hline Bakang & hutan & $\begin{array}{l}1 \text { pohon dlm } 10 \text { th } \varnothing \pm 20-30 \\
\mathrm{~cm}\end{array}$ & papan balok, tiang \\
\hline Bisuhu & hutan & $\begin{array}{l}1 \text { pohon dlm } 10 \text { th } \varnothing \pm 20-30 \\
\mathrm{~cm}\end{array}$ & tiang dan papan \\
\hline Asah & hutan & 1 pohon dlm 20 th $\varnothing \pm 30 \mathrm{~cm}$ & balok \\
\hline Rambutan lokal & hutan & 1 pohon dlm 20 th $\varnothing \pm 30 \mathrm{~cm}$ & balok \\
\hline Sengon & & 10 th $2-3 \mathrm{~m}^{3}$ & $\begin{array}{l}\text { lantai rumah dan dinding, balok kayu, } \\
\text { tiang dan balok, tiang }\end{array}$ \\
\hline Suren & kebun & 5 pohon umur 7 tahun & \\
\hline Rambutan & kebun & 2 pohon & \\
\hline
\end{tabular}




\begin{tabular}{|c|c|c|c|}
\hline Jenis Kehati & $\begin{array}{c}\text { Lokasi } \\
\text { Pengambilan }\end{array}$ & $\begin{array}{l}\text { Volume dan Frekuensi } \\
\text { pemanenan }\end{array}$ & Tujuan Pemanfaatan \\
\hline Nangka & kebun & 5 pohon & \\
\hline Suren & lahan sendiri & 5 pohon $\varnothing 30 \mathrm{~cm}$ & tiang rumah \\
\hline Bisuhu & lahan sendiri & 1 pohon $\varnothing 80 \mathrm{~cm}\left(2 \mathrm{~m}^{3}\right)$ & lantai, dinding \\
\hline Sengon & lahan sendiri & 1 pohon $\varnothing 50 \mathrm{~cm}$ & balok penyangga, lantai/galangan \\
\hline $\begin{array}{l}\text { Sagu (daunnya yg muda tapi } \\
\text { sudah mulai hijau) }\end{array}$ & kawasan & $\begin{array}{l}\text { 7x selama 2010-2015@ } 20 \\
\text { pelepah }\end{array}$ & atap rumah \\
\hline Sengon putih & $\begin{array}{l}\text { kawasan } \\
\text { produksi }\end{array}$ & $\begin{array}{l}2 \text { pohon }\left(1 \mathrm{~m}^{3}\right) \text { 2010-2015 } \\
\text { dari pohon tumbang }\end{array}$ & bahan dinding, lantairenovasi rumah \\
\hline Bakau & $\begin{array}{l}\text { kawasan } \\
\text { produksi }\end{array}$ & & bahan tiang, tangga \\
\hline Suren & $\begin{array}{l}\text { kawasan } \\
\text { produksi }\end{array}$ & & tiang lantai, tangga \\
\hline Asa & kawasan & tidak dihitung banyaknya & untuk rumah : tiang \\
\hline Bisuhu & kawasan & & tiang rumah \\
\hline Nangka & kawasan & & tiang rumah \\
\hline Colok (sengon) & kawasan & & papan \\
\hline Dapu & & & reng \\
\hline Sengon & lahan sendiri & $15 \mathrm{~m}^{3}$ & untuk dinding lantai \\
\hline Suren & lahan sendiri & $0,5 \mathrm{~m}^{3}$ & untuk dudukan lantai \\
\hline Nangka & lahan sendiri & $2 \mathrm{~m}^{3}$ & untuk tiang \\
\hline Bayam jawa & lahan sendiri & $0,5 \mathrm{~m}^{3}$ & untuk kaso2 \\
\hline Bakung merah & lahan sendiri & $1 \mathrm{~m}^{3}$ & untuk kaso2 \\
\hline Galatri/ganitri & lahan sendiri & $0,5 \mathrm{~m}^{3}$ & untuk reng \\
\hline Bisuhu & lahan sendiri & $1,5 \mathrm{~m}^{3}$ & papan untuk lantai/dinding \\
\hline Rambutan hutan & lahan sendiri & $0,75 \mathrm{~m}^{3}$ & tiang2 penyangga rumah \\
\hline Albasia & kebun & $2 \mathrm{~m}^{3}(14 \mathrm{th})$ & papan, balok \\
\hline Cendana & kebun & $3,25 \mathrm{~m}^{3}(20 \mathrm{th})$ & tiang kusen \\
\hline Dadap & kebun & & mal \\
\hline Gmelina & kebun & & pintu \\
\hline Bakau merah & kebun & & kusen \\
\hline Nangka & kebun & & tangga \\
\hline
\end{tabular}


Lampiran 3.4 Pemanfaatan jenis tumbuhan untuk peralatan rumah tangga

\begin{tabular}{|c|c|c|c|}
\hline Jenis Kehati & Lokasi Pengambilan & $\begin{array}{l}\text { Volume dan Frekuensi } \\
\text { pemanenan }\end{array}$ & Tujuan Pemanfaatan \\
\hline Jati Putih & Kebun milik & 2 pohon & Untuk lemari \\
\hline Jati Putih & Kebun milik & -- & Untuk meja makan \\
\hline Kayu Bitih & Kebun milik & -- & Untuk kursi makan \\
\hline Jati putih & & & untuk lemari dan dipan \\
\hline Jati putih & & & meja makan \\
\hline Johar & Iahan milik sendiri & $0,5 \mathrm{~m}^{3}$ & untuk digunakan sendiri \\
\hline Nangka & Iahan milik sendiri & $0,5 \mathrm{~m}^{3}$ & \\
\hline Bisuhu & Iahan milik sendiri & $0,5 \mathrm{~m}^{3}$ & \\
\hline Nangka & 1 pohon dalam 10 th & & gagang cangkul, golok, sabit, pisau \\
\hline Sengon & 2 pohon per 5 th & & meja, kursi, lemari \\
\hline Suren, bisuhu & 1 phn per 10 thn & & meja, kursi, lemari \\
\hline Bakang & 1 phn per 10 thn & & $\begin{array}{l}\text { meja, kursi, lemari, sude (entong), pengaduk nasi, } \\
\text { penumbuk bumbu }\end{array}$ \\
\hline Nangka dan suren & & & meja, kursi, lemari \\
\hline Bambu & & & pagar \\
\hline
\end{tabular}


Lampiran 3.5 Pemanfaatan jenis tumbuhan untuk bahan bangunan di DAS Balantieng

\begin{tabular}{|c|c|c|c|}
\hline Jenis Kehati & $\begin{array}{l}\text { Lokasi } \\
\text { Pengambilan }\end{array}$ & $\begin{array}{l}\text { Volume dan Frekuensi } \\
\text { pemanenan }\end{array}$ & Tujuan Pemanfaatan \\
\hline Sengon & Dari Kebun & $7 \mathrm{~m}^{3}$ & untuk dinding, lantai, kaso-kaso \\
\hline Mangga & Dari Kebun & $0,5 \mathrm{~m}^{3}$ & untuk lantai \\
\hline Bitih & Dari Kebun & $1 \mathrm{~m}^{3}$ & untuk tangga dan listplang \\
\hline Batang kelapa & Dari Kebun & $1 \mathrm{~m}^{3}$ & Palang dudukan lantai, kuda-kuda \\
\hline Jati Putih & Kebun sendiri & 20 pohon $\left(7 \mathrm{~m}^{3}\right)$ & $\begin{array}{l}\text { untuk bangun rumah/ rangka } \\
\text { rumah }\end{array}$ \\
\hline Kayu Bitih & Kebun sendiri & 5 pohon & $\begin{array}{l}\text { untuk bangun rumah/ daun } \\
\text { jendela }\end{array}$ \\
\hline Jati putih & Kebun & 10 pohon $\left(2 \mathrm{~m}^{3}\right)$ & Untuk rumah \\
\hline Korek (sengon) & Kebun & & \\
\hline \multicolumn{4}{|l|}{$\begin{array}{l}\text { Papan meranti (beli jadi), } \\
\text { sengon putih }\end{array}$} \\
\hline Jati putih & Kebun & $3 \mathrm{~m}^{3}$ (umur 7 thn saat ditebang) & $\begin{array}{l}\text { Tiang, balok, daun pintu, kusen } \\
\text { jendela }\end{array}$ \\
\hline Jati putih & pekarangan & & \\
\hline Biti & & & $\begin{array}{l}\text { kusen, daun pintu, balok, rangka } \\
\text { atap }\end{array}$ \\
\hline Sengon & Kasawan Hutan & $1 \mathrm{phn}\left(2 \mathrm{~m}^{3}\right)$ & $\begin{array}{l}\text { Renovasi (Rangka atap, plafon } \\
\text { dan dinding) }\end{array}$ \\
\hline Rambutan hutan & Belakang rumah & $2 \mathrm{phn}\left(1,5 \mathrm{~m}^{3}\right)$ & $\begin{array}{l}\text { dipakai sendiri unt memperbaiki } \\
\text { rumah }\end{array}$ \\
\hline Kayu rambutan & Kawasan hutan & 2 phn $\left(0,5 \mathrm{~m}^{3}\right)$ & $\begin{array}{l}\text { untuk memperbaiki rumah } \\
\text { (rangka rumah) }\end{array}$ \\
\hline $\begin{array}{l}\text { Kayu Nangka, Bilalang, } \\
\text { Rambutan hutan }\end{array}$ & & & Balok \\
\hline Bayam & & & $\begin{array}{l}\text { Rangka, kaso-kaso, pintu dan } \\
\text { kusen }\end{array}$ \\
\hline Sengon & Kawasan Hutan & 10 pohon dalam 10 tahun & \\
\hline Rambutan & Kawasan Hutan & 5 pohon & \\
\hline Sengon & Dalam kawasan & $1 \mathrm{x}=1 \mathrm{~m}^{3} \mathrm{dlm}$ bentuk papan $(40$ & mbar) \\
\hline $\begin{array}{l}\text { Sengon (untuk papan). } \\
\text { Sengon } 1,5 \text { juta/m3 }\end{array}$ & Kebun & $1 \mathrm{~m}^{3}$ & Rumah \\
\hline Kayu besi (untuk kusen) & Kebun & $1 \mathrm{~m}^{3}$ & \\
\hline Jati (untuk pintu, balok) & Kebun & $1 \mathrm{~m}^{3}$ & Di jual dan bikin rumah \\
\hline \multicolumn{4}{|c|}{ Rambutan hutan, nato, mangga macan. Harga rambutan hutan Rp. $3 \mathrm{jt} / \mathrm{m}^{3}$} \\
\hline Sengon & Iahan milik & $3 \mathrm{~m}^{3}$ & $\begin{array}{l}\text { untuk bangun rumah sendiri Th. } \\
2014\end{array}$ \\
\hline Bakang & Iahan milik & $1 \mathrm{~m}^{3}$ & \\
\hline Kupang & Iahan milik & $0,5 \mathrm{~m}^{3}$ & \\
\hline Johar & lahan milik & $0,5 \mathrm{~m}^{3}$ & \\
\hline Suren & Iahan milik & $0,5 \mathrm{~m}^{4}$ & \\
\hline Sengon & hutan & 2 pohon, $1 \times 5$ th $\left(1,5 \mathrm{~m}^{3}\right)$ & papan balok \\
\hline Nangka & hutan & 1 pohon dlm 10 th $\varnothing \pm 25 \mathrm{~cm}$ & benteng (tiang) \\
\hline Suren & hutan & 1 pohon dlm 10 th $\varnothing \pm 25 \mathrm{~cm}$ & balok \\
\hline Bakang & hutan & 1 pohon dlm 10 th $\varnothing \pm 20-30 \mathrm{~cm}$ & papan balok, tiang \\
\hline Bisuhu & hutan & 1 pohon dlm 10 th $\varnothing \pm 20-30 \mathrm{~cm}$ & tiang dan papan \\
\hline Asah & hutan & 1 pohon dlm 20 th $\varnothing \pm 30 \mathrm{~cm}$ & balok \\
\hline Rambutan lokal & hutan & 1 pohon dlm 20 th $\varnothing \pm 30 \mathrm{~cm}$ & balok \\
\hline Sengon & & 10 th $2-3 \mathrm{~m}^{3}$ & $\begin{array}{l}\text { lantai rumah dan dinding, balok } \\
\text { kayu, tiang dan balok, tiang }\end{array}$ \\
\hline Suren & kebun & 5 pohon umur 7 tahun & \\
\hline
\end{tabular}




\begin{tabular}{|c|c|c|c|}
\hline Jenis Kehati & $\begin{array}{c}\text { Lokasi } \\
\text { Pengambilan }\end{array}$ & $\begin{array}{l}\text { Volume dan Frekuensi } \\
\text { pemanenan }\end{array}$ & Tujuan Pemanfaatan \\
\hline Rambutan & kebun & 2 pohon & \\
\hline Nangka & kebun & 5 pohon & \\
\hline Suren & Iahan sendiri & 5 pohon $\varnothing 30 \mathrm{~cm}$ & tiang rumah \\
\hline Bisuhu & lahan sendiri & 1 pohon $\varnothing 80 \mathrm{~cm}\left(2 \mathrm{~m}^{3}\right)$ & lantai, dinding \\
\hline Sengon & lahan sendiri & 1 pohon $\varnothing 50 \mathrm{~cm}$ & balok penyangga, lantai/galangan \\
\hline $\begin{array}{l}\text { Sagu (daunnya yg muda tapi } \\
\text { sudah mulai hijau) }\end{array}$ & kawasan & $\begin{array}{l}\text { 7x selama 2010-2015 @ } 20 \\
\text { pelepah }\end{array}$ & atap rumah \\
\hline Sengon putih & $\begin{array}{l}\text { kawasan } \\
\text { produksi }\end{array}$ & $\begin{array}{l}2 \text { pohon }\left(1 \mathrm{~m}^{3}\right) 2010-2015 \text { dari } \\
\text { pohon tumbang }\end{array}$ & $\begin{array}{l}\text { bahan dinding, lantairenovasi } \\
\text { rumah }\end{array}$ \\
\hline Bakau & $\begin{array}{l}\text { kawasan } \\
\text { produksi }\end{array}$ & & bahan tiang, tangga \\
\hline Suren & $\begin{array}{l}\text { kawasan } \\
\text { produksi }\end{array}$ & & tiang lantai, tangga \\
\hline Asa & kawasan & tidak dihitung banyaknya & untuk rumah: tiang \\
\hline Bisuhu & kawasan & & tiang rumah \\
\hline Nangka & kawasan & & tiang rumah \\
\hline Colok (sengon) & kawasan & & papan \\
\hline Dapu & & & reng \\
\hline Sengon & lahan sendiri & $15 \mathrm{~m}^{3}$ & untuk dinding lantai \\
\hline Suren & lahan sendiri & $0,5 \mathrm{~m}^{3}$ & untuk dudukan lantai \\
\hline Nangka & lahan sendiri & $2 \mathrm{~m}^{3}$ & untuk tiang \\
\hline Bayam jawa & lahan sendiri & $0,5 \mathrm{~m}^{3}$ & untuk kaso-kaso \\
\hline Bakung merah & lahan sendiri & $1 \mathrm{~m}^{3}$ & untuk kaso-kaso \\
\hline Galatri/ganitri & lahan sendiri & $0,5 \mathrm{~m}^{3}$ & untuk reng \\
\hline Bisuhu & lahan sendiri & $1,5 \mathrm{~m}^{3}$ & papan untuk lantai/dinding \\
\hline Rambutan hutan & lahan sendiri & $0,75 \mathrm{~m}^{3}$ & Tiang-tiang penyangga rumah \\
\hline Albasia & kebun & $2 \mathrm{~m}^{3}$ (14 th) & papan, balok \\
\hline Cendana & kebun & $3,25 \mathrm{~m}^{3}$ (20 th) & tiang kusen \\
\hline Dadap & kebun & & mal \\
\hline Gmelina & kebun & & pintu \\
\hline Bakau merah & kebun & & kusen \\
\hline Nangka & kebun & & tangga \\
\hline
\end{tabular}


Lampiran 3.6 Pemanfaatan jenis tumbuhan untuk peralatan rumah tangga

\begin{tabular}{|c|c|c|c|}
\hline Jenis Kehati & Lokasi Pengambilan & $\begin{array}{l}\text { Volume dan Frekuensi } \\
\text { pemanenan }\end{array}$ & Tujuan Pemanfaatan \\
\hline Jati Putih & Kebun milik & 2 pohon & Untuk lemari \\
\hline Jati Putih & Kebun milik & -- & Untuk meja makan \\
\hline Kayu Bitih & Kebun milik & -- & Untuk kursi makan \\
\hline Jati putih & & & untuk lemari dan dipan \\
\hline Jati putih & & & meja makan \\
\hline Johar & Iahan milik sendiri & $0,5 \mathrm{~m}^{3}$ & untuk digunakan sendiri \\
\hline Nangka & Iahan milik sendiri & $0,5 \mathrm{~m}^{3}$ & \\
\hline Bisuhu & Iahan milik sendiri & $0,5 \mathrm{~m}^{3}$ & \\
\hline Nangka & 1 pohon dalam 10 thn & & gagang cangkul, golok, sabit, pisau \\
\hline Sengon & 2 pohon per 5 thn & & meja, kursi, lemari \\
\hline Suren, bisuhu & 1 phn per 10 thn & & meja, kursi, lemari \\
\hline Bakang & 1 phn per 10 thn & & $\begin{array}{l}\text { meja, kursi, lemari, sude (entong), pengaduk nasi, } \\
\text { penumbuk bumbu }\end{array}$ \\
\hline Nangka dan suren & & & meja, kursi, lemari \\
\hline Bambu & & & pagar \\
\hline
\end{tabular}


Lampiran 3.7 Pemanfaatan jenis tumbuhan untuk kayu bakar

\begin{tabular}{|c|c|c|c|}
\hline Jenis Kehati & $\begin{array}{c}\text { Lokasi } \\
\text { Pengambilan }\end{array}$ & $\begin{array}{l}\text { Volume dan Frekuensi } \\
\text { pemanenan }\end{array}$ & Tujuan Pemanfaatan \\
\hline $\begin{array}{l}\text { Kayu cengkeh, sengon, gamal, } \\
\text { bitih, rambutan, coklat }\end{array}$ & Kebun & 2 ikat & $\begin{array}{l}\text { untk memasak air dan nasi } \\
\text { gas/LPG digunakan sampingan } \\
\text { saja (dlm } 2 \text { minggu habis) }\end{array}$ \\
\hline Gamal, sengon & Kebun & 1-2 ikat & $\begin{array}{l}\text { untuk keperluan masak air } \\
\text { (temporer) krn sdh } \\
\text { menggunakan gas }\end{array}$ \\
\hline Jati putih, ambas & Kebun & $1 \mathrm{ikat} /$ minggu & Masak air, bakar-bakar \\
\hline $\begin{array}{l}\text { Ranting jatuh dari pohon : Ampas, } \\
\text { jati putih, sengon merah }\end{array}$ & $\begin{array}{l}\text { kebun sendiri dan } \\
\text { orang lain }\end{array}$ & $0,5 \mathrm{~m} \times 0,5 \mathrm{~m} \times 1 \mathrm{~m} / \mathrm{bln}$ & Konsumsi \\
\hline $\begin{array}{l}\text { Ranting jatuh dari pohon : Ampas, } \\
\text { jati putih, sengon merah }\end{array}$ & $\begin{array}{l}\text { kebun sendiri dan } \\
\text { orang lain }\end{array}$ & $0,5 \mathrm{~m} \times 0,5 \mathrm{~m} \times 1 \mathrm{~m} / \mathrm{bln}$ & Konsumsi \\
\hline $\begin{array}{l}\text { ranting/kayu gamal, jati putih, } \\
\text { coklat, dll }\end{array}$ & kebun & 2 ikat/bulan & $\begin{array}{l}\text { masak air \& masak lontong/ } \\
\text { ketupat }\end{array}$ \\
\hline $\begin{array}{l}\text { ranting/kayu: jati putih, gamal, kopi, } \\
\text { coklat, kayu kerek }\end{array}$ & & $8 \mathrm{ikat} / \mathrm{bln}$ & masak air \\
\hline $\begin{array}{l}\text { Rambutan hutan, Sengon, Bayam } \\
\text { jawa }\end{array}$ & Kasawan Hutan & $\begin{array}{l}\text { Campur-campur, yang kering, } \\
\text { jatuh/mati berdiri } 2 \text {-3 x/thn @ 1/4 } \\
\text { m3. Berkurang karena sdh } \\
\text { menggunakan gas. Konsumsi } \\
\text { kayu bakar meningkat ketika: } \\
\text { musim panen lada. }\end{array}$ & Konsumsi/masak air \\
\hline Sengon, dll & Kebun & 1-2 ikat & $\begin{array}{l}\text { untk memasak sewaktu-waktu } \\
\text { krn sdh ada gas }\end{array}$ \\
\hline $\begin{array}{l}\text { Jambu mete, sengon, rambutan, } \\
\text { kopi }\end{array}$ & $\begin{array}{l}\text { Kawasan dan } \\
\text { kebun milik orang } \\
\text { lain }\end{array}$ & 2 ikat untuk 2 hari & untuk keperluan masak sendiri \\
\hline Kopi, rambutan hutan, sengon & Kebun & $1 \mathrm{ikat} / 3$ hari & \\
\hline Sengon, rambutan & Kawasan hutan & 10 ikat/tahun & $\begin{array}{l}\text { Masak air (penggunaan kayu } \\
\text { bakar berkurang krn sdh ada gas }\end{array}$ \\
\hline Karet + sengon & Kebun sendiri & $\begin{array}{l}2 \text { ikat (banyak berkurang krn th } \\
\text { ada gas sejak tahun 2010) }\end{array}$ & \\
\hline $\begin{array}{l}\text { Cabang dan ranting kayu : sengon } \\
\text { dan rambutan }\end{array}$ & Dalam kawasan & 1 ikat ( lebih dari 10 batang) & $\begin{array}{l}\text { Untuk memasak (bergangian } \\
\text { dengan Gas) }\end{array}$ \\
\hline $\begin{array}{l}\text { Walau sudah ada gas tetap masih } \\
\text { menggunakan, ranting-ranting yang } \\
\text { jatuh, mati berdiri dari pohon : } \\
\text { Rambutan hutan, sengon, bayam } \\
\text { jawa }\end{array}$ & Kawasan Hutan & $2-3 x /$ th @1/4 m & Konsumsi/masak \\
\hline \multicolumn{4}{|l|}{$\begin{array}{l}\text { Ranting-ranting dari kayu : colo } \\
\text { (sengon) dan mete }\end{array}$} \\
\hline Linre, kopi, cengkeh dan nangka & & & \\
\hline
\end{tabular}


Lampiran 3.8 Pemanfaatan jenis tumbuhan untuk budaya

\begin{tabular}{|c|c|c|c|}
\hline Jenis Kehati & $\begin{array}{c}\text { Lokasi } \\
\text { Pengambilan }\end{array}$ & $\begin{array}{l}\text { Volume dan Frekuensi } \\
\text { pemanenan }\end{array}$ & Tujuan Pemanfaatan \\
\hline $\begin{array}{l}\text { Daun kelapa, pohon bambu, batang, pisang, } \\
\text { salak, jeruk, nenas, pisang, markisa }\end{array}$ & Kebun & Disesuaikan kebutuhan & pesta pernikahan \\
\hline Bambu, dibuat lasuji dihiasi daun aren + ijuk & & & pesta pernikahan \\
\hline Kelapa, nangka, markisa & & & pesta pernikahan \\
\hline janur dari pohon aren & kebun & 1 pelepah muda & pesta pernikahan \\
\hline Pinang & Kebun & $\begin{array}{l}40 \text { bh yang tua (tandan } \\
\text { pinang) }\end{array}$ & pesta pernikahan \\
\hline Pinang & kebun & & pesta pernikahan \\
\hline Sire & & & pesta pernikahan \\
\hline Kelapa & & & pesta pernikahan \\
\hline Pisang belai & kebun sendiri & 1 phn + buahnya & pesta pernikahan \\
\hline Markisa & & $\begin{array}{l}20-50 \text { bh tergantung } \\
\text { besar kecilnya pohon } \\
\text { pisang }\end{array}$ & pesta pernikahan \\
\hline Jeruk & & $10-20 \mathrm{bh}$ & pesta pernikahan \\
\hline Daun kelapa & & 1 tandan yang muda & pesta pernikahan \\
\hline Daun aren muda & & 1 tandan yang muda & pesta pernikahan \\
\hline Sirih & & 7-15 ikat & pesta pernikahan \\
\hline Pinang & & 7-15 buah & pesta pernikahan \\
\hline Tebu & & $2 \mathrm{bh}$ & pesta pernikahan \\
\hline Gula merah & & 1 buah & pesta pernikahan \\
\hline Kelapa buah & & 2 buah & pesta pernikahan \\
\hline Daun kelapa & & 1 pucuk & pesta pernikahan \\
\hline Pucuk aren & & 2 pucuk & pesta pernikahan \\
\hline Pisang ambon atau emas & & $2 \mathrm{btg}$ & pesta pernikahan \\
\hline
\end{tabular}




\section{WORKING PAPERS WITH DOIS}

2005

1. Agroforestry in the drylands of eastern Africa: a call to action

2. Biodiversity conservation through agroforestry: managing tree species diversity within a network of community-based, nongovernmental, governmental and research organizations in western Kenya.

3. Invasion of prosopis juliflora and local livelihoods: Case study from the Lake Baringo area of Kenya

4. Leadership for change in farmers organizations: Training report: Ridar Hotel, Kampala, 29th March to 2nd April 2005.

5. Domestication des espèces agroforestières au Sahel : situation actuelle et perspectives

6. Relevé des données de biodiversité ligneuse: Manuel du projet biodiversité des parcs agroforestiers au Sahel

7. Improved land management in the Lake Victoria Basin: TransVic Project's draft report.

8. Livelihood capital, strategies and outcomes in the Taita hills of Kenya

9. Les espèces ligneuses et leurs usages: Les préférences des paysans dans le Cercle de Ségou, au Mali

10. La biodiversité des espèces ligneuses: Diversité arborée et unités de gestion du terroir dans le Cercle de Ségou, au Mali

\section{6}

11. Bird diversity and land use on the slopes of Mt. Kilimanjaro and the adjacent plains, Tanzania

12. Water, women and local social organization in the Western Kenya Highlands

13. Highlights of ongoing research of the World Agroforestry Centre in Indonesia

14. Prospects of adoption of tree-based systems in a rural landscape and its likely impacts on carbon stocks and farmers' welfare: The FALLOW Model Application in Muara Sungkai, Lampung, Sumatra, in a 'Clean Development Mechanism' context

15. Equipping integrated natural resource managers for healthy Agroforestry landscapes.

17. Agro-biodiversity and CGIAR tree and forest science: approaches and examples from Sumatra.

18. Improving land management in eastern and southern Africa: A review of policies.

19. Farm and household economic study of Kecamatan Nanggung, Kabupaten Bogor, Indonesia: A socio-economic base line study of Agroforestry innovations and livelihood enhancement.

20. Lessons from eastern Africa's unsustainable charcoal business.

21. Evolution of RELMA's approaches to land management: Lessons from two decades of research and development in eastern and southern Africa

22. Participatory watershed management: Lessons from RELMA's work with farmers in eastern Africa.

23. Strengthening farmers' organizations: The experience of RELMA and ULAMP.

24. Promoting rainwater harvesting in eastern and southern Africa.

25. The role of livestock in integrated land management.

26. Status of carbon sequestration projects in Africa: Potential benefits and challenges to scaling up. 
27. Social and Environmental Trade-Offs in Tree Species Selection: A Methodology for Identifying Niche Incompatibilities in Agroforestry [Appears as AHI Working Paper no. 9]

28. Managing tradeoffs in agroforestry: From conflict to collaboration in natural resource management. [Appears as AHI Working Paper no. 10]

29. Essai d'analyse de la prise en compte des systemes agroforestiers pa les legislations forestieres au Sahel: Cas du Burkina Faso, du Mali, du Niger et du Senegal.

30. Etat de la recherche agroforestière au Rwanda etude bibliographique, période 1987-2003

2007

31. Science and technological innovations for improving soil fertility and management in Africa: A report for NEPAD's Science and Technology Forum.

32. Compensation and rewards for environmental services.

33. Latin American regional workshop report compensation.

34. Asia regional workshop on compensation ecosystem services.

35. Report of African regional workshop on compensation ecosystem services.

36. Exploring the inter-linkages among and between compensation and rewards for ecosystem services CRES and human well-being

37. Criteria and indicators for environmental service compensation and reward mechanisms: realistic, voluntary, conditional and pro-poor

38. The conditions for effective mechanisms of compensation and rewards for environmental services.

39. Organization and governance for fostering Pro-Poor Compensation for Environmental Services.

40. How important are different types of compensation and reward mechanisms shaping poverty and ecosystem services across Africa, Asia \& Latin America over the Next two decades?

41. Risk mitigation in contract farming: The case of poultry, cotton, woodfuel and cereals in East Africa.

42. The RELMA savings and credit experiences: Sowing the seed of sustainability

43. Yatich J., Policy and institutional context for NRM in Kenya: Challenges and opportunities for Landcare.

44. Nina-Nina Adoung Nasional di So! Field test of rapid land tenure assessment (RATA) in the Batang Toru Watershed, North Sumatera.

45. Is Hutan Tanaman Rakyat a new paradigm in community based tree planting in Indonesia?

46. Socio-Economic aspects of brackish water aquaculture (Tambak) production in Nanggroe Aceh Darrusalam.

47. Farmer livelihoods in the humid forest and moist savannah zones of Cameroon.

48. Domestication, genre et vulnérabilité : Participation des femmes, des Jeunes et des catégories les plus pauvres à la domestication des arbres agroforestiers au Cameroun.

49. Land tenure and management in the districts around Mt Elgon: An assessment presented to the Mt Elgon ecosystem conservation programme.

50. The production and marketing of leaf meal from fodder shrubs in Tanga, Tanzania: A pro-poor enterprise for improving livestock productivity.

51. Buyers Perspective on Environmental Services (ES) and Commoditization as an approach to liberate ES markets in the Philippines. 
52. Towards Towards community-driven conservation in southwest China: Reconciling state and local perceptions.

53. Biofuels in China: An Analysis of the Opportunities and Challenges of Jatropha curcas in Southwest China.

54. Jatropha curcas biodiesel production in Kenya: Economics and potential value chain development for smallholder farmers

55. Livelihoods and Forest Resources in Aceh and Nias for a Sustainable Forest Resource Management and Economic Progress

56. Agroforestry on the interface of Orangutan Conservation and Sustainable Livelihoods in Batang Toru, North Sumatra.

2008

57. Assessing Hydrological Situation of Kapuas Hulu Basin, Kapuas Hulu Regency, West Kalimantan.

58. Assessing the Hydrological Situation of Talau Watershed, Belu Regency, East Nusa Tenggara.

59. Kajian Kondisi Hidrologis DAS Talau, Kabupaten Belu, Nusa Tenggara Timur.

60. Kajian Kondisi Hidrologis DAS Kapuas Hulu, Kabupaten Kapuas Hulu, Kalimantan Barat.

61. Lessons learned from community capacity building activities to support agroforest as sustainable economic alternatives in Batang Toru orang utan habitat conservation program (Martini, Endri et al.)

62. Mainstreaming Climate Change in the Philippines.

63. A Conjoint Analysis of Farmer Preferences for Community Forestry Contracts in the Sumber Jaya Watershed, Indonesia.

64. The highlands: a shared water tower in a changing climate and changing Asia

65. Eco-Certification: Can It Deliver Conservation and Development in the Tropics.

66. Designing ecological and biodiversity sampling strategies. Towards mainstreaming climate change in grassland management.

67. Towards mainstreaming climate change in grassland management policies and practices on the Tibetan Plateau

68. An Assessment of the Potential for Carbon Finance in Rangelands

69 ECA Trade-offs Among Ecosystem Services in the Lake Victoria Basin.

69. The last remnants of mega biodiversity in West Java and Banten: an in-depth exploration of RaTA (Rapid Land Tenure Assessment) in Mount Halimun-Salak National Park Indonesia

70. Le business plan d'une petite entreprise rurale de production et de commercialisation des plants des arbres locaux. Cas de quatre pépinières rurales au Cameroun.

71. Les unités de transformation des produits forestiers non ligneux alimentaires au Cameroun. Diagnostic technique et stratégie de développement Honoré Tabuna et Ingratia Kayitavu.

72. Les exportateurs camerounais de safou (Dacryodes edulis) sur le marché sous régional et international. Profil, fonctionnement et stratégies de développement.

73. Impact of the Southeast Asian Network for Agroforestry Education (SEANAFE) on agroforestry education capacity.

74. Setting landscape conservation targets and promoting them through compatible land use in the Philippines.

75. Review of methods for researching multistrata systems. 
76. Study on economical viability of Jatropha curcas L. plantations in Northern Tanzania assessing farmers' prospects via cost-benefit analysis

77. Cooperation in Agroforestry between Ministry of Forestry of Indonesia and International Center for Research in Agroforestry

78. "China's bioenergy future. an analysis through the Lens if Yunnan Province

79. Land tenure and agricultural productivity in Africa: A comparative analysis of the economics literature and recent policy strategies and reforms

80. Boundary organizations, objects and agents: linking knowledge with action in Agroforestry watersheds

81. Reducing emissions from deforestation and forest degradation (REDD) in Indonesia: options and challenges for fair and efficient payment distribution mechanisms

2009

82. Mainstreaming climate change into agricultural education: challenges and perspectives

83. Challenging conventional mindsets and disconnects in conservation: the emerging role of ecoagriculture in Kenya's landscape mosaics

84. Lesson learned RATA garut dan bengkunat: suatu upaya membedah kebijakan pelepasan kawasan hutan dan redistribusi tanah bekas kawasan hutan

85. The emergence of forest land redistribution in Indonesia

86. Commercial opportunities for fruit in Malawi

87. Status of fruit production processing and marketing in Malawi

88. Fraud in tree science

89. Trees on farm: analysis of global extent and geographical patterns of agroforestry

90. The springs of Nyando: water, social organization and livelihoods in Western Kenya

91. Building capacity toward region-wide curriculum and teaching materials development in agroforestry education in Southeast Asia

92. Overview of biomass energy technology in rural Yunnan (Chinese - English abstract)

93. A pro-growth pathway for reducing net GHG emissions in China

94. Analysis of local livelihoods from past to present in the central Kalimantan Ex-Mega Rice Project area

95. Constraints and options to enhancing production of high quality feeds in dairy production in Kenya, Uganda and Rwanda

2010

96. Agroforestry education in the Philippines: status report from the Southeast Asian Network for Agroforestry Education (SEANAFE)

97. Economic viability of Jatropha curcas L. plantations in Northern Tanzania- assessing farmers' prospects via cost-benefit analysis.

98. Hot spot of emission and confusion: land tenure insecurity, contested policies and competing claims in the central Kalimantan Ex-Mega Rice Project area

99. Agroforestry competences and human resources needs in the Philippines

100. CES/COS/CIS paradigms for compensation and rewards to enhance environmental Services 
101. Case study approach to region-wide curriculum and teaching materials development in agroforestry education in Southeast Asia

102. Stewardship agreement to reduce emissions from deforestation and degradation (REDD): Lubuk Beringin's Hutan Desa as the first village forest in Indonesia

103. Landscape dynamics over time and space from ecological perspective

104. Komoditisasi atau koinvestasi jasa lingkungan: skema imbal jasa lingkungan program peduli sungai di DAS Way Besai, Lampung, Indonesia

105. Improving smallholders' rubber quality in Lubuk Beringin, Bungo district, Jambi province, Indonesia: an initial analysis of the financial and social benefits

106. Rapid Carbon Stock Appraisal (RACSA) in Kalahan, Nueva Vizcaya, Philippines

107. Tree domestication by ICRAF and partners in the Peruvian Amazon: lessons learned and future prospects in the domain of the Amazon Initiative eco-regional program

108. Memorias del Taller Nacional: "Iniciativas para Reducir la Deforestación en la region Andino Amazónica", 09 de Abril del 2010. Proyecto REALU Peru

109. Percepciones sobre la Equidad y Eficiencia en la cadena de valor de REDD en Perú -Reporte de Talleres en Ucayali, San Martín y Loreto, 2009. Proyecto REALU-Perú.

110. Reducción de emisiones de todos los Usos del Suelo. Reporte del Proyecto REALU Perú Fase 1

111. Programa Alternativas a la Tumba-y-Quema (ASB) en el Perú. Informe Resumen y Síntesis de la Fase II. 2da. versión revisada

112. Estudio de las cadenas de abastecimiento de germoplasma forestal en la amazonía Boliviana

113. Biodiesel in the Amazon

114. Estudio de mercado de semillas forestales en la amazonía Colombiana

115. Estudio de las cadenas de abastecimiento de germoplasma forestal en Ecuador http://dx.doi.org10.5716/WP10340.PDF

116. How can systems thinking, social capital and social network analysis help programs achieve impact at scale?

117. Energy policies, forests and local communities in the Ucayali Region, Peruvian Amazon

118. NTFPs as a Source of Livelihood Diversification for Local Communities in the Batang Toru Orangutan Conservation Program

119. Studi Biodiversitas: Apakah agroforestry mampu mengkonservasi keanekaragaman hayati di DAS Konto?

120. Estimasi Karbon Tersimpan di Lahan-lahan Pertanian di DAS Konto, Jawa Timur

121. Implementasi Kaji Cepat Hidrologi (RHA) di Hulu DAS Brantas, Jawa Timur. http://dx.doi.org/10.5716/WP10338.PDF

122. Kaji Cepat Hidrologi di Daerah Aliran Sungai Krueng Peusangan, NAD,Sumatra http://dx.doi.org/10.5716/WP10337.PDF

123. A Study of Rapid Hydrological Appraisal in the Krueng Peusangan Watershed, NAD, Sumatra. http://dx.doi.org/10.5716/WP10339.PDF

2011

124. An Assessment of farm timber value chains in Mt Kenya area, Kenya

125. A Comparative financial analysis of current land use systems and implications for the adoption of improved agroforestry in the East Usambaras, Tanzania

126. Agricultural monitoring and evaluation systems 
127. Challenges and opportunities for collaborative landscape governance in the East Usambara Mountains, Tanzania

128. Transforming Knowledge to Enhance Integrated Natural Resource Management Research, Development and Advocacy in the Highlands of Eastern Africa http://dx.doi.org/10.5716/WP11084.PDF

129. Carbon-forestry projects in the Philippines: potential and challenges The Mt Kitanglad Range forest-carbon development http://dx.doi.org10.5716/WP11054.PDF

130. Carbon forestry projects in the Philippines: potential and challenges. The Arakan Forest Corridor forest-carbon project. http://dx.doi.org10.5716/WP11055.PDF

131. Carbon-forestry projects in the Philippines: potential and challenges. The Laguna Lake Development Authority's forest-carbon development project. http://dx.doi.org/10.5716/WP11056.PDF

132. Carbon-forestry projects in the Philippines: potential and challenges. The Quirino forest-carbon development project in Sierra Madre Biodiversity Corridor http://dx.doi.org10.5716/WP11057.PDF

133. Carbon-forestry projects in the Philippines: potential and challenges. The Ikalahan Ancestral Domain forest-carbon development http://dx.doi.org10.5716/WP11058.PDF

134. The Importance of Local Traditional Institutions in the Management of Natural Resources in the Highlands of Eastern Africa. http://dx.doi.org/10.5716/WP11085.PDF

135. Socio-economic assessment of irrigation pilot projects in Rwanda. http://dx.doi.org/10.5716/WP11086.PDF

136. Performance of three rambutan varieties (Nephelium lappaceum L.) on various nursery media. http://dx.doi.org/10.5716/WP11232.PDF

137. Climate change adaptation and social protection in agroforestry systems: enhancing adaptive capacity and minimizing risk of drought in Zambia and Honduras http://dx.doi.org/10.5716/WP11269.PDF

138. Does value chain development contribute to rural poverty reduction? Evidence of asset building by smallholder coffee producers in Nicaragua http://dx.doi.org/10.5716/WP11271.PDF

139. Potential for biofuel feedstock in Kenya. http://dx.doi.org/10.5716/WP11272.PDF

140. Impact of fertilizer trees on maize production and food security in six districts of Malawi. http://dx.doi.org/10.5716/WP11281.PDF

2012

141. Fortalecimiento de capacidades para la gestión del Santuario Nacional Pampa Hermosa: Construyendo las bases para un manejo adaptativo para el desarrollo local. Memorias del Proyecto. http://dx.doi.org/10.5716/WP12005.PDF

142. Understanding rural institutional strengthening: A cross-level policy and institutional framework for sustainable development in Kenya http://dx.doi.org/10.5716/WP12012.PDF

143. Climate change vulnerability of agroforestry http://dx.doi.org/10.5716/WP16722.PDF

144. Rapid assesment of the inner Niger delta of Mali http://dx.doi.org/10.5716/WP12021.PDF

145. Designing an incentive program to reduce on-farm deforestationin the East Usambara Mountains, Tanzania http://dx.doi.org/10.5716/WP12048.PDF

146. Extent of adoption of conservation agriculture and agroforestry in Africa: the case of Tanzania, Kenya, Ghana, and Zambia http://dx.doi.org/10.5716/WP12049.PDF 
147. Policy incentives for scaling up conservation agriculture with trees in Africa: the case of Tanzania, Kenya, Ghana and Zambia http://dx.doi.org/10.5716/WP12050.PDF

148. Commoditized or co-invested environmental services? Rewards for environmental services scheme: River Care program Way Besai watershed, Lampung, Indonesia.

http://dx.doi.org/10.5716/WP12051.PDF

149. Assessment of the headwaters of the Blue Nile in Ethiopia. http://dx.doi.org/10.5716/WP12160.PDF

150. Assessment of the uThukela Watershed, Kwazaulu. http://dx.doi.org/10.5716/WP12161.PDF

151. Assessment of the Oum Zessar Watershed of Tunisia. http://dx.doi.org/10.5716/WP12162.PDF

152. Assessment of the Ruwenzori Mountains in Uganda. http://dx.doi.org/10.5716/WP12163.PDF

153. History of agroforestry research and development in Viet Nam. Analysis of research opportunities and gaps. http://dx.doi.org/10.5716/WP12052.PDF

154. REDD+ in Indonesia: a Historical Perspective. http://dx.doi.org/10.5716/WP12053.PDF

155. Agroforestry and Forestry in Sulawesi series: Livelihood strategies and land use system dynamics in South Sulawesi http://dx.doi.org/10.5716/WP12054.PDF

156. Agroforestry and Forestry in Sulawesi series: Livelihood strategies and land use system dynamics in Southeast Sulawesi. http://dx.doi.org/10.5716/WP12055.PDF

157. Agroforestry and Forestry in Sulawesi series: Profitability and land-use systems in South and Southeast Sulawesi. http://dx.doi.org/10.5716/WP12056.PDF

158. Agroforestry and Forestry in Sulawesi series: Gender, livelihoods and land in South and Southeast Sulawesi http://dx.doi.org/10.5716/WP12057.PDF

159. Agroforestry and Forestry in Sulawesi series: Agroforestry extension needs at the community level in AgFor project sites in South and Southeast Sulawesi, Indonesia. http://dx.doi.org/10.5716/WP12058.PDF

160. Agroforestry and Forestry in Sulawesi series: Rapid market appraisal of agricultural, plantation and forestry commodities in South and Southeast Sulawesi.

http://dx.doi.org/10.5716/WP12059.PDF

2013

161. Diagnosis of farming systems in the Agroforestry for Livelihoods of Smallholder farmers in Northwestern Viet Nam project http://dx.doi.org/10.5716/WP13033.PDF

162. Ecosystem vulnerability to climate change: a literature review. http://dx.doi.org/10.5716/WP13034.PDF

163. Local capacity for implementing payments for environmental services schemes: lessons from the RUPES project in northeastern Viet Nam http://dx.doi.org/10.5716/WP13046.PDF

164. Seri Agroforestri dan Kehutanan di Sulawesi: Agroforestry dan Kehutanan di Sulawesi: Strategi mata pencaharian dan dinamika sistem penggunaan lahan di Sulawesi Selatan http://dx.doi.org/10.5716/WP13040.PDF

165. Seri Agroforestri dan Kehutanan di Sulawesi: Mata pencaharian dan dinamika sistem penggunaan lahan di Sulawesi Tenggara http://dx.doi.org/10.5716/WP13041.PDF

166. Seri Agroforestri dan Kehutanan di Sulawesi: Profitabilitas sistem penggunaan lahan di Sulawesi Selatan dan Sulawesi Tenggara http://dx.doi.org/10.5716/WP13042.PDF

167. Seri Agroforestri dan Kehutanan di Sulawesi: Gender, mata pencarian dan lahan di Sulawesi Selatan dan Sulawesi Tenggara http://dx.doi.org/10.5716/WP13043.PDF 
168. Seri Agroforestri dan Kehutanan di Sulawesi: Kebutuhan penyuluhan agroforestri pada tingkat masyarakat di lokasi proyek AgFor di Sulawesi Selatan dan Tenggara, Indonesia. http://dx.doi.org/10.5716/WP13044.PDF

169. Seri Agroforestri dan Kehutanan di Sulawesi: Laporan hasil penilaian cepat untuk komoditas pertanian, perkebunan dan kehutanan di Sulawesi Selatan dan Tenggara http://dx.doi.org/10.5716/WP13045.PDF

170. Agroforestry, food and nutritional security http://dx.doi.org/10.5716/WP13054.PDF

171. Stakeholder Preferences over Rewards for Ecosystem Services: Implications for a REDD+ Benefit Distribution System in Viet Nam http://dx.doi.org/10.5716/WP13057.PDF

172. Payments for ecosystem services schemes: project-level insights on benefits for ecosystems and the rural poor http://dx.doi.org/10.5716/WP13001.PDF

173. Good practices for smallholder teak plantations: keys to success http://dx.doi.org/10.5716/WP13246.PDF

174. Market analysis of selected agroforestry products in the Vision for Change Project intervention Zone, Côte d'Ivoire http://dx.doi.org/10.5716/WP13249.PDF

175. Rattan futures in Katingan: why do smallholders abandon or keep their gardens in Indonesia's 'rattan district'? http://dx.doi.org/10.5716/WP13251.PDF

176. Management along a gradient: the case of Southeast Sulawesi's cacao production landscapes http://dx.doi.org/10.5716/WP13265.PDF

2014

177. Are trees buffering ecosystems and livelihoods in agricultural landscapes of the Lower Mekong Basin? Consequences for climate-change adaptation. http://dx.doi.org/10.5716/WP14047.PDF

178. Agroforestry, livestock, fodder production and climate change adaptation and mitigation in East Africa: issues and options. http://dx.doi.org/10.5716/WP14050.PDF

179. Trees on farms: an update and reanalysis of agroforestry's global extent and socio-ecological characteristics. http://dx.doi.org/10.5716/WP14064.PDF

180. Beyond reforestation: an assessment of Vietnam's REDD+ readiness. http://dx.doi.org/10.5716/WP14097.PDF

181. Farmer-to-farmer extension in Kenya: the perspectives of organizations using the approach. http://dx.doi.org/10.5716/WP14380.PDF

182. Farmer-to-farmer extension in Cameroon: a survey of extension organizations. http://dx.doi.org/10.5716/WP14383.PDF

183. Farmer-to-farmer extension approach in Malawi: a survey of organizations: a survey of organizations http://dx.doi.org/10.5716/WP14391.PDF

184. Seri Agroforestri dan Kehutanan di Sulawesi: Kuantifikasi jasa lingkungan air dan karbon pola agroforestri pada hutan rakyat di wilayah sungai Jeneberang

185. Options for Climate-Smart Agriculture at Kaptumo Site in Kenyahttp://dx.doi.org/10.5716/WP14394.PDF

2015

186. Agroforestry for Landscape Restoration and Livelihood Development in Central Asia http://dx.doi.org/10.5716/WP14143.PDF 
187. "Projected Climate Change and Impact on Bioclimatic Conditions in the Central and SouthCentral Asia Region" http://dx.doi.org/10.5716/WP14144.PDF

188. Land Cover Changes, Forest Loss and Degradation in Kutai Barat, Indonesia. http://dx.doi.org/10.5716/WP14145.PDF

189. The Farmer-to-Farmer Extension Approach in Malawi: A Survey of Lead Farmers. http://dx.doi.org/10.5716/WP14152.PDF

190. Evaluating indicators of land degradation and targeting agroforestry interventions in smallholder farming systems in Ethiopia. http://dx.doi.org/10.5716/WP14252.PDF

191. Land health surveillance for identifying land constraints and targeting land management options in smallholder farming systems in Western Cameroon

192. Land health surveillance in four agroecologies in Malawi

193. Cocoa Land Health Surveillance: an evidence-based approach to sustainable management of cocoa landscapes in the Nawa region, South-West Côte d'Ivoire http://dx.doi.org/10.5716/WP14255.PDF

194. Situational analysis report: Xishuangbanna autonomous Dai Prefecture, Yunnan Province, China. http://dx.doi.org/10.5716/WP14255.PDF

195. Farmer-to-farmer extension: a survey of lead farmers in Cameroon. http://dx.doi.org/10.5716/WP15009.PDF

196. From transition fuel to viable energy source Improving sustainability in the sub-Saharan charcoal sector http://dx.doi.org/10.5716/WP15011.PDF

197. Mobilizing Hybrid Knowledge for More Effective Water Governance in the Asian Highlands http://dx.doi.org/10.5716/WP15012.PDF

198. Water Governance in the Asian Highlands http://dx.doi.org/10.5716/WP15013.PDF

199. Assessing the Effectiveness of the Volunteer Farmer Trainer Approach in Dissemination of Livestock Feed Technologies in Kenya vis-à-vis other Information Sources http://dx.doi.org/10.5716/WP15022.PDF

200. The rooted pedon in a dynamic multifunctional landscape: Soil science at the World Agroforestry Centre http://dx.doi.org/10.5716/WP15023.PDF

201. Characterising agro-ecological zones with local knowledge. Case study: Huong Khe district, $\mathrm{Ha}$ Tinh, Viet Nam http://dx.doi.org/10.5716/WP15050.PDF

202. Looking back to look ahead: Insight into the effectiveness and efficiency of selected advisory approaches in the dissemination of agricultural technologies indicative of Conservation Agriculture with Trees in Machakos County, Kenya. http://dx.doi.org/10.5716/WP15065.PDF

203. Pro-poor Biocarbon Projects in Eastern Africa Economic and Institutional Lessons. http://dx.doi.org/10.5716/WP15022.PDF

204. Projected climate change impacts on climatic suitability and geographical distribution of banana and coffee plantations in Nepal. http://dx.doi.org/10.5716/WP15294.PDF

205. Agroforestry and Forestry in Sulawesi series: Smallholders' coffee production and marketing in Indonesia. A case study of two villages in South Sulawesi Province. http://dx.doi.org/10.5716/WP15690.PDF

206. Mobile phone ownership and use of short message service by farmer trainers: a case study of Olkalou and Kaptumo in Kenya http://dx.doi.org/10.5716/WP15691.PDF

207. Associating multivariate climatic descriptors with cereal yields: a case study of Southern Burkina Faso http://dx.doi.org/10.5716/WP15273.PDF

208. Preferences and adoption of livestock feed practices among farmers in dairy management groups in Kenya http://dx.doi.org/10.5716/WP15675.PDF 
209. Scaling up climate-smart agriculture: lessons learned from South Asia and pathways for success http://dx.doi.org/10.5716/WP15720.PDF

210. Agroforestry and Forestry in Sulawesi series: Local perceptions of forest ecosystem services and collaborative formulation of reward mechanisms in South and Southeast Sulawesi http://dx.doi.org/10.5716/WP15721.PDF

211. Potential and challenges in implementing the co-investment of ecosystem services scheme in Buol District, Indonesia. http://dx.doi.org/10.5716/WP15722.PDF

212. Tree diversity and its utilization by the local community in Buol District, Indonesia http://dx.doi.org/10.5716/WP15723.PDF

213 Vulnerability of smallholder farmers and their preferences on farming practices in Buol District, Indonesia http://dx.doi.org/10.5716/WP15724.PDF

214. Dynamics of Land Use/Cover Change and Carbon Emission in Buol District, Indonesia http://dx.doi.org/10.5716/WP15725.PDF

215. Gender perspective in smallholder farming practices in Lantapan, Phillippines. http://dx.doi.org/10.5716/WP15726.PDF

216. Vulnerability of smallholder farmers in Lantapan, Bukidnon. http://dx.doi.org/10.5716/WP15727.PDF

217. Vulnerability and adaptive capacity of smallholder farmers in Ho Ho Sub-watershed, Ha Tinh Province, Vietnam http://dx.doi.org/10.5716/WP15728.PDF

218. Local Knowledge on the role of trees to enhance livelihoods and ecosystem services in northern central Vietnam http://dx.doi.org/10.5716/WP15729.PDF

219. Land-use/cover change in Ho Ho Sub-watershed, Ha Tinh Province, Vietnam. http://dx.doi.org/10.5716/WP15730.PDF

2016

220. Agroforestry and Forestry in Sulawesi series: Evaluation of the Agroforestry Farmer Field Schools on agroforestry management in South and Southeast Sulawesi, Indonesia. http://dx.doi.org/10.5716/WP16002.PDF

221. Farmer-to-farmer extension of livestock feed technologies in Rwanda: A survey of volunteer farmer trainers and organizations. http://dx.doi.org/10.5716/WP16005.PDF

222. Projected Climate Change Impact on Hydrology, Bioclimatic Conditions, and Terrestrial Ecosystems in the Asian Highlands http://dx.doi.org/10.5716/WP16006.PDF

223. Adoption of Agroforestry and its impact on household food security among farmers in Malawi http://dx.doi.org/10.5716/WP16013.PDF

224. Agroforestry and Forestry in Sulawesi series: Information channels for disseminating innovative agroforestry practices to villages in Southern Sulawesi, Indonesia http://dx.doi.org/10.5716/WP16034.PDF

225. Agroforestry and Forestry in Sulawesi series: Unravelling rural migration networks.Landtenure arrangements among Bugis migrant communities in Southeast Sulawesi. http://dx.doi.org/10.5716/WP16035.PDF

226. Agroforestry and Forestry in Sulawesi series: Women's participation in agroforestry: more benefit or burden? A gendered analysis of Gorontalo Province. http://dx.doi.org/10.5716/WP16036.PDF

227. Kajian Kelayakan dan Pengembangan Desain Teknis Rehabilitasi Pesisir di Sulawesi Tengah. http://dx.doi.org/10.5716/WP16037.PDF

228. Selection of son tra clones in North West Vietnam. http://dx.doi.org/10.5716/WP16038.PDF 
229. Growth and fruit yield of seedlings, cuttings and grafts from selected son tra trees in Northwest Vietnam http://dx.doi.org/10.5716/WP16046.PDF

230. Gender-Focused Analysis of Poverty and Vulnerability in Yunnan, China http://dx.doi.org/10.5716/WP16071.PDF

231. Seri Agroforestri dan Kehutanan di Sulawesi: Kebutuhan Penyuluhan Agroforestri untuk Rehabilitasi Lahan di Sumba Timur, Nusa Tenggara Timur, Indonesia. http://dx.doi.org/10.5716/WP16077.PDF

232. Agroforestry and Forestry in Sulawesi series: Agroforestry extension needs for land rehabilitation in East Sumba, East Nusa Tenggara, Indonesia. http://dx.doi.org/10.5716/WP16078.PDF

233. Central hypotheses for the third agroforestry paradigm within a common definition. http://dx.doi.org/10.5716/WP16079.PDF

234. Assessing smallholder farmers' interest in shade coffee trees: The Farming Systems of Smallholder Coffee Producers in the Gisenyi Area, Rwanda: a participatory diagnostic study. http://dx.doi.org/10.5716/WP16104.PDF

235. Review of agricultural market information systems in |sub-Saharan Africa. http://dx.doi.org/10.5716/WP16110.PDF

236. Vision and road map for establishment of a protected area in Lag Badana, Lower Jubba, Somalia. http://dx.doi.org/10.5716/WP16127.PDF

237. Replicable tools and frameworks for Bio-Carbon Development in West Africa. http://dx.doi.org/10.5716/WP16138.PDF

238. Existing Conditions, Challenges and Needs in the Implementation of Forestry and Agroforestry Extension in Indonesia. http://dx.doi.org/10.5716/WP16141.PDF

239. Situasi Terkini, Tantangan dan Kebutuhan Pelaksanaan Penyuluhan Kehutanan dan Agroforestri di Indonesia. http://dx.doi.org/10.5716/WP16142.PDF

240. The national agroforestry policy of India: experiential learning in development and delivery phases. http://dx.doi.org/10.5716/WP16143.PDF

241. Agroforestry and Forestry in Sulawesi series: Livelihood strategies and land-use system dynamics in Gorontalo. http://dx.doi.org/10.5716/WP16157.PDF

242. Seri Agroforestri dan Kehutanan di Sulawesi: Strategi mata pencaharian dan dinamika sistem penggunaan lahan di Gorontalo. http://dx.doi.org/10.5716/WP16158.PDF

243. Ruang, Gender dan Kualitas Hidup Manusia: Sebuah studi Gender pada komunitas perantau dan pengelola kebun di Jawa Barat. http://dx.doi.org/10.5716/WP16159.PDF

244. Gendered Knowledge and perception in managing grassland areas in East Sumba, Indonesia. http://dx.doi.org/10.5716/WP16160.PDF

245. Pengetahuan dan persepsi masyarakat pengelola padang aavana, Sebuah Kajian Gender di Sumba Timur. http://dx.doi.org/10.5716/WP16161.PDF

246. Dinamika Pengambilan Keputusan pada komunitas perantau dan pengelola kebun di Jawa Barat. http://dx.doi.org/10.5716/WP16162.PDF

247. Gaharu (eaglewood) domestication: Biotechnology, markets and agroforestry options. http://dx.doi.org/10.5716/WP16163.PDF

248. Marine habitats of the Lamu-Kiunga coast: an assessment of biodiversity value, threats and opportunities. http://dx.doi.org/10.5716/WP16167.PDF

249. Assessment of the biodiversity in terrestrial landscapes of the Witu protected area and surroundings, Lamu County Kenya. http://dx.doi.org/10.5716/WP16172.PDF

250. An ecosystem services perspective on benefits that people derive from biodiversity of Coastal forests in Lamu County, Kenya http://dx.doi.org/10.5716/WP16173.PDF 
251. Assessment of the biodiversity in terrestrial and marine landscapes of the proposed Laga Badana National Park and surrounding areas, Jubaland, Somalia.

http://dx.doi.org/10.5716/WP16174.PDF

2017

252. Preferensi Petani terhadap Topik Penyuluhan dan Penyebaran Informasi Agroforestri di Indonesia. http://dx.doi.org/10.5716/WP16181.PDF

253. Seri Agroforestri dan Kehutanan di Sulawesi: Keanekaragaman hayati jenis pohon pada hutan rakyat agroforestri di DAS Balangtieng, Sulawesi Selatan.

http://dx.doi.org/10.5716/WP16182.PDF 

The World Agroforestry Centre is an autonomous, non-profit research organization whose vision is a rural transformation in the developing world as smallholder households increase their use of trees in agricultural landscapes to improve food security, nutrition, income, health, shelter, social cohesion, energy resources and environmental sustainability. The Centre generates science-based knowledge about the diverse roles that trees play in agricultural landscapes, and uses its research to advance policies and practices, and their implementation that benefit the poor and the environment. It aims to ensure that all this is achieved by enhancing the quality of its science work, increasing operational efficiency, building and maintaining strong partnerships, accelerating the use and impact of its research, and promoting greater cohesion, interdependence and alignment within the organization.

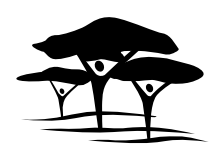

United Nations Avenue, Gigiri • PO Box 30677 • Nairobi, $00100 \cdot$ Kenya Telephone: +254207224000 or via USA +16508336645 Fax: +254207224001 or via USA +16508336646 Email: worldagroforestry@cgiar.org•www.worldagroforestry.org

Southeast Asia Regional Program • Sindang Barang • Bogor 16680 PO Box $161 \cdot$ Bogor $16001 \cdot$ Indonesia

Telephone: +62 $2518625415 \cdot$ Fax: +62 2518625416 